\author{
UNIVERSIDADE DE SÃO PAULO \\ ESCOLA DE ARTES, CIÊNCIAS E HUMANIDADES \\ PROGRAMA DE PÓS-GRADUAÇÃO EM TÊXTIL E MODA
}

ANA PAULA GENTILE

Gestão de resíduos têxteis na Manufatura do Vestuário de Moda em Malharia Retilínea: estudo de múltiplos casos 


\title{
Gestão de resíduos têxteis na Manufatura do Vestuário de Moda em Malharia Retilínea: estudo de múltiplos casos
}

\author{
Versão corrigida
}

Dissertação apresentada à Escola de Artes, Ciências e Humanidades da Universidade de São Paulo para obtenção do título de Mestre em Ciências pelo Programa de Pós-graduação em Têxtil e Moda.

Versão corrigida contendo as alterações solicitadas pela comissão julgadora em 19 de outubro de 2017. $A$ versão original encontra-se em acervo reservado na Biblioteca da EACH/USP e na Biblioteca Digital de Teses e Dissertações da USP (BDTD), de acordo com a Resolução CoPGr 6018, de 13 de outubro de 2011.

Área de Concentração:

Têxtil e Moda

Orientador:

Prof ${ }^{\text {a }}$. Dra․․ Francisca Dantas Mendes

São Paulo 
Autorizo a reprodução e divulgação total ou parcial deste trabalho, por qualquer meio convencional ou eletrônico, para fins de estudo e pesquisa, desde que citada a fonte.

CATALOGAÇÃO-NA-PUBLICAÇÃO

(Universidade de São Paulo. Escola de Artes, Ciências e Humanidades. Biblioteca)

Gentile, Ana Paula

Gestão de resíduos têxteis na manufatura do vestuário de moda em malharia retilínea : estudo de múltiplos casos / Ana Paula Gentile ; orientadora, Francisca Dantas Mendes. - 2017

$137 \mathrm{p}$.

Dissertação (Mestrado em Ciências) - Programa de Pós-

Graduação em Têxtil e Moda, Escola de Artes, Ciências e Humanidades, Universidade de São Paulo

Versão corrigida

1. Indústria têxtil - Aspectos ambientais. 2. Vestuário -

Fabricação. 3. Resíduos. 4. Impactos ambientais. I. Mendes,

Francisca Dantas, orient. II. Título.

CDD 22.ed. - 677

CRB-8 4936 
Nome: GENTILE, Ana Paula

Título: Gestão de resíduos têxteis na Manufatura do Vestuário de Moda em Malharia Retilínea: estudo de múltiplos casos

Dissertação apresentada à Escola de Artes, Ciências e Humanidades da Universidade de São Paulo para obtenção do título de Mestre em Ciências pelo Programa de Pós-graduação em Têxtil e Moda.

Área de Concentração:

Têxtil e Moda

Aprovado em: 19 / 10 / 2017

\section{Banca Examinadora}

Prof. Dr. João Amato Neto

Universidade de São Paulo. Escola Politécnica

Prof ${ }^{a}$. Dr ${ }^{\mathrm{a}}$. Denise Dantas

Universidade de São Paulo. Faculdade de Arquitetura e Urbanismo

Prof ${ }^{\mathrm{a}}$. Dra . Isabel Silva Sampaio

Universidade Mogi das Cruzes 
Dedico este trabalho a minha mãe Anna Lúcia Gentile, que com imenso amor, motivação e incentivo me apoiou e orientou em todas as conquistas da minha Vida, e em memória do meu querido pai Paolo Gentile, que se ainda estivesse entre nós ficaria muito feliz e orgulhoso desta realização. 


\section{Agradecimentos}

Agradeço primeiro a Deus pelo dom da vida, e força que tem me concedido nesta caminhada.

Agradeço minha mãe Anna Lúcia Gentile, que com muito amor e carinho proporcionou um caminho sempre ao meu lado acreditando na concretização deste. Agradeço igualmente ao meu pai que com todo amor me educou e transmitiu sua cultura, e que me impulsionou a esta conquista desde o início, mas não pode ver este finalizado, porém sempre estará presente em meu coração.

A minha família pela compreensão e ajuda em destaque aos meus irmãos Fernanda Gentile, Umberto Domenico Gentile e Angelina Pinilha juntamente com meu cunhado Marcelo Pinilha sempre dispostos e interessados em todos os momentos.

Agradeço de coração a minha cunhada Renata V. de Oliveira Gentile, que desde o princípio do projeto se mostrou empenhada em colaborar e apoiar, em todas as fases de realização com entusiasmo e paciência.

Agradeço especialmente ao Dr. Antônio Cardoso Pinto, médico excepcional, que com toda a sua sabedoria me medicou e guiou para que este estudo pudesse ter continuidade.

Minha imensa gratidão a orientadora, Prof. a. Dra. Francisca Dantas Mendes, por sua dedicação e incentivo e por acreditar no meu potencial.

Agradeço a todos da associação ACIMS de Monte Sião, em especial Sr. João Tadeu Dorta Machado, por sua sabedoria e cooperação importantíssima para a concepção deste.

A todos os malharistas que fizeram parte deste estudo com suas experiências, abrindo seus espaços e permitindo o acesso, e sem o qual esta pesquisa não seria possível. Aos colaboradores desta pesquisa que me receberam com compreensão, e vontade em poder contribuir com o estudo, o meu muito obrigado ao senhor Benedito Lacir Taveira e sua esposa, exemplos em dedicação que mostraram o sentido do trabalho em sua jornada, e que tive o enorme privilégio em conhecer. 
Agradeço a querida Mônica Ribeiro da Rosa, representante da Stoll, que com seu carisma e bom humor acolheu gentilmente o estudo e proporcionou enriquecimento e muita inspiração nesta estrada.

A todo grupo de monges do Mosteiro Santíssima Trindade que se propuseram a colaborar com seus conhecimentos, em especial ao Ir. Silvio pelo acolhimento e contato e também meu muito obrigado a Ir. Damaris, que cooperou consideravelmente com seus relatos e experiências.

Aos membros da banca de qualificação, João Amato Neto e Denise Dantas, pelas considerações que atribuíram para o fortalecimento desta pesquisa, além da compreensão e paciência. Bem como aos demais professores que tive o privilégio de conhecer e com os quais tive a oportunidade de aprender.

Agradeço a secretaria da pós-graduação em Têxtil e Moda bem como os atendentes da biblioteca da Escola de Artes Ciências e Humanidades da Universidade de São Paulo (EACH-USP) pela gentileza e respaldo.

Agradeço a todos os amigos e as pessoas que desde o início do mestrado me incentivaram e direta ou indiretamente me apoiaram no desenvolvimento deste trabalho até sua finalização. 
"Crio meus designs a partir de muitas peças de tecido, as quais costuro umas nas outras para descobrir a forma que eu quero. Neste sentido, acho que trato a moda mais como um escultor do que como um alfaiate".

(Sandra Backlund) 


\section{RESUMO}

GENTILE, Ana Paula. Gestão de resíduos têxteis na Manufatura do Vestuário de Moda em Malharia Retilínea: estudo de múltiplos casos. 2017. 137f. Dissertação (Mestrado em Ciências) - Escola de Artes, Ciências e Humanidades, Universidade de São Paulo, São Paulo, 2017. Versão Corrigida.

Esta pesquisa qualitativa buscou a realidade ambiental da produção industrial de malharias selecionadas na região de Monte Sião, em Minas Gerais, quanto a maior ou menor presença de preocupações de "produção mais limpa", bem como sua visão em termos de redução do uso de água, de energia, e, especialmente, de resíduos sólidos têxteis. Justificou-se pelas preocupações relacionadas ao meio ambiente e sua preservação que implicam em questões cada vez mais pertinentes e abordadas nos estudos relacionados ao vestuário de moda, tal como o design que está inteiramente conectado às mudanças cotidianas, e interessado na redução de materiais. É neste contexto que se encontra a produção mais limpa $(P+L)$, almejando agregar melhorias no processo ou no produto, buscando soluções por meio da apresentação de alguns processos que norteiam estes caminhos. Em vista disso, foi elaborada uma revisão da literatura especializada em têxtil, moda e cenários ambientais, e foi realizada uma investigação de campo baseada em métodos qualitativos exploratório de pesquisa, utilizando-se de observações diretas e entrevistas semiestruturadas efetuadas junto às malharias. Alguns resultados da investigação sugerem que a realidade ambiental da produção industrial de malharias tenha uma aproximação com a produção mais limpa, sobretudo, em relação ao tratamento dado aos resíduos sólidos têxteis. Na abordagem da pesquisa de campo observaram-se diferenças quanto às ações voltadas para a minimização de água, energia, e a geração de resíduos sólidos têxteis, ao passo que evidenciaram uma preocupação e tratamentos aos mesmos, indicando de certa forma que existe um equilíbrio quanto ao direcionamento do resíduo têxtil e a dedicação no tratamento, sendo um importante ponto de cuidado do polo industrial.

Palavras-chaves: Impacto ambiental. Malharia retilínea. Manufatura do vestuário de moda. Produção mais limpa. 


\begin{abstract}
GENTILE, Ana Paula. Textile Waste Management in the manufacture of fashionable clothing in rectilinear knitting: multiple case study. 2017. 137p. Dissertation (Master of Science) - School of Arts, Sciences and Humanities, University of São Paulo, São Paulo, 2017. Corrected version.
\end{abstract}

This qualitative research sought the environmental reality of some selected industrial knitting production in the region of Monte Sião, in Minas Gerais, regarding the greater or lesser presence of "cleaner production" concerns, as well as its vision in terms of reduction of water use, energy, and especially solid textile waste. It has been justified by the environmental concerns and their preservation that imply issues increasingly relevant and addressed in studies related to fashion clothing, such as design that is fully connected to everyday changes, and interested in reducing materials. Cleaner production is found in this context, aiming to add improvements in the process or product, seeking solutions through the presentation of some processes that guide these paths. A review of the literature on textiles, fashion and environmental scenarios and a field research were carried out based on qualitative exploratory research methods, using direct observations and semi-structured interviews accomplished onsite. Some research results suggest that the environmental reality of the industrial production of knitting products is in line with cleaner production, especially in relation to the treatment of solid textile waste. In the field research approach, differences were observed regarding actions aimed at minimizing water, energy, and solid textile waste generation, while showing them a concern and treatments, indicating in a certain way that there is a balance to the direction of the textile waste and the dedication in the treatment, being an important point of care of the industrial pole.

Keywords: Cleaner production. Environmental impact. Fashion clothing manufacturing. Rectilinear knitting. 


\section{LISTA DE FIGURAS}

Figura 1 - Evolução das empresas rumo a Produção mais Limpa. ..........................26

Figura 2 - Representação da interação entre os fluxos de diversos sistemas. ..........30

Figura 3 - Representação de uma empresa onde são aplicados conceito de Produção

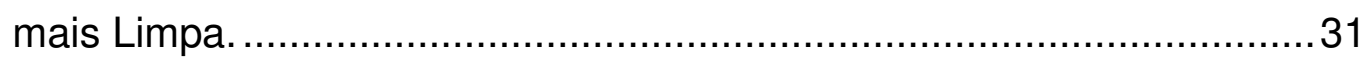

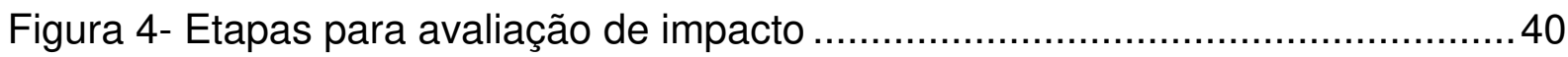

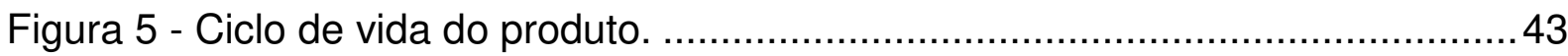

Figura 6 - Principais estágios do ciclo de vida de um produto. .................................4 44

Figura 7 - Caracterização e classificação de resíduos. ............................................ 45

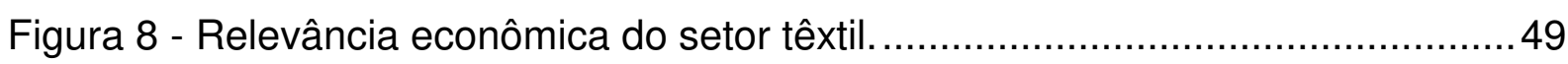

Figura 9 - Cadeia Têxtil Completa e sua rede de negócios.....................................51

Figura 10 - Divisões da Malharia e maquinários. .................................................52

Figura 11 - Cadeia têxtil completa e sua rede de negócios......................................53

Figura 12 - Processo produtivo de malharia retilínea envolvendo tecelagens

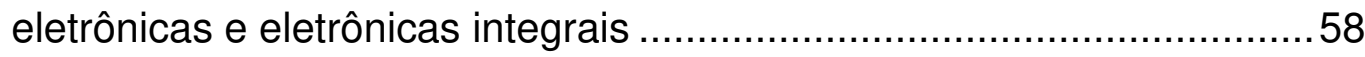

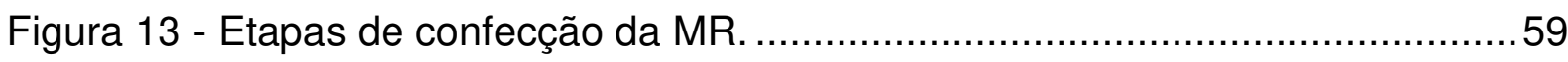

Figura 14 - Quadro da estrutura metodológica da pesquisa....................................76

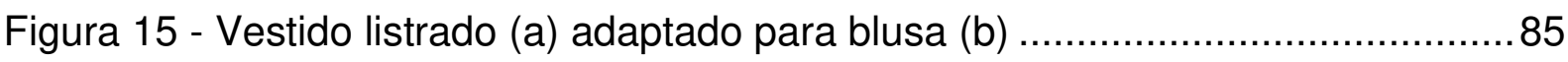

Figura 16 - Casaco produzido com a mistura de fios que seriam descartados, destaque ampliado da textura da peça no lado avesso. ..................................... 88

Figura 17 - Pesagem do pacote, pacote contendo resíduos têxteis de malharia. ..... 89

Figura 18 - Processo produtivo de malharia retilinea com destinação de seus resíduos textêis. 100

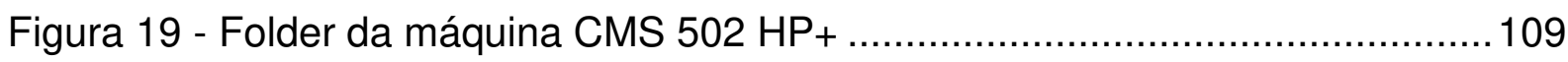

Figura 20 - Informação do catalogo da máquina CMS 502 multi galga ..................110

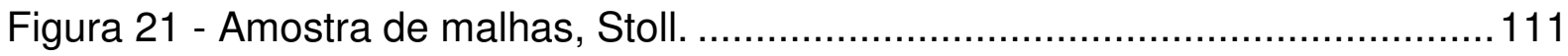

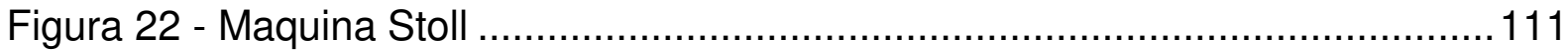

Figura 23 - Amostra de blusa infantil apresentada na FEBRATEX 2016 ...............113

Figura 24 - Fluxograma do processo produtivo usando máquina de peça pronta...114 Figura 25 - Fluxograma do processo produtivo usando máquina de tecimento

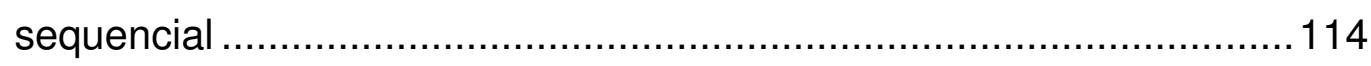

Figura 26 - Look composto por vestido e jaqueta...............................................116 
Figura 27 - Look composto por jaqueta casual jeans malha, blusa e calça clean...116

Figura 28 - Calçado modelado lado direito/avesso

Figura 29 - Amostra de tênis realizado em máquina de peça pronta Stoll 118

Figura 30 - Caixas de resíduo de tricô armazenados atualmente em baixo da mesa do corte Mosteiro setor de confecção. 120

Figura 31 - Pacote de resíduos doados ao mosteiro. 120

Figura 32 - Seleção de malhas por cor. 121

Figura 33 - Colocação renda sobreposta a camurça.......................................123

Figura 34 - Aplicação de camurça com bordado em perolas. ..............................123

Figura 35 - Blusa semi pronta com detalhes texturas. ...................................... 123

Figura 36 - Blusa semi pronta com abertura ombro. .................................... 123

Figura 37 - Setor de reciclagem Pôr do Sol situada em Monte Sião, MG. ..............125

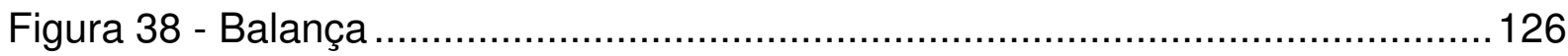

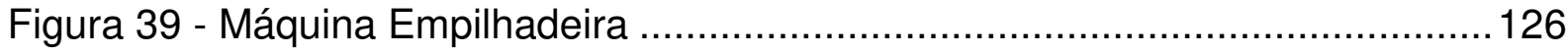

Figura 40 - Fardos empilhados no setor de reciclagem. ................................... 127

Figura 41 - Mesa de ferro com grades setor de reciclagem. ............................ 128

Figura 42 - Prensa automática onde formam se os fardos no setor de reciclagem. 129

Figura 43 - Prensa sendo acionada. ...................................................... 129

Figura 44 - Fardo de uma cor só 180 kg setor de reciclagem. ............................130

Figura 45 - Caixas contendo têxtil chamado de cor única ...................................131

Figura 46 - Fardos de cor única prontos para serem transportados.......................131

Figura 47 - Fardos de mil cores prontos para serem transportados...................... 132

Figura 48 - Fardo de 180 kg chamado mil cores. ........................................... 132

Figura 49 - Caixa de resíduos contendo cones de fios de papelão misturados com cones de plásticos, garrafas pet e fios. .....................................133

Figura 50 - Caixa contendo cones de papelão ordenados para a remanufatura.....134

Figura 51 - Papelão separado para ser prensado................................................ 134

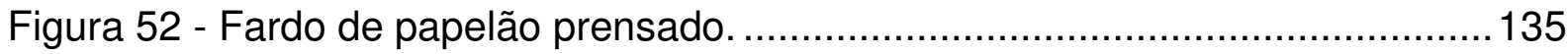

Figura 53 - Peça elaborada no setor de reciclagem ..................................... 137

Figura 54 - Cardigan com abotoamento duplo ......................................... 137 


\section{LISTA DE GRÁFICOS}

Gráfico 1 - Níveis de oportunidade de Produção mais Limpa. ................................28

Gráfico 2 - Desenvolvimento histórico da Produção mais Limpa. ...........................29

Gráfico 3 - Participação dos estados no ROL da indústria têxtil do Brasil................. 48

Gráfico 4 - Média das máquinas instaladas por tipo no Brasil entre os anos de 2008 a

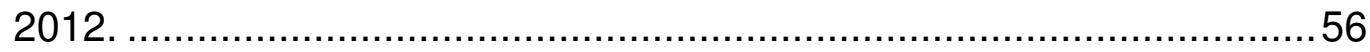




\section{LISTA DE QUADROS}

Quadro 1 - Diferenças entre tecnologias fim de tubo e Produção mais Limpa..........25

Quadro 2 - Eras da conscientização ambiental. ............................................ 34

Quadro 3 - Os três objetivos para a ecoeficiência no mundo estabelecida pelo

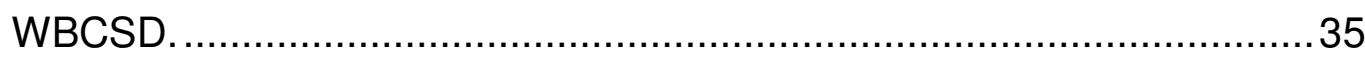

Quadro 4 - Resumo dos aspectos e impactos ambientais no setor têxtil. ................60

Quadro 5 - Entrada e saída de insumos de algumas etapas do processo produtivo têxtil. 60

Quadro 6 - Exemplos de boas práticas ambientais para o setor têxtil. 62

Quadro 7 - Perfil da Empresa 79

Quadro 8 - Síntese da realidade das indústrias pesquisadas em relação às categoria conceituais que emergiam na análise de dados coletados em 2016 e 2017

Quadro 9 - Quadro geral de formas de atuação em gestão ambiental empresarial, segundo modelo de Barbieri (2006) indicando a incidência de ações ambientalistas nas seis empresas pesquisadas.

Quadro 10 - Analise geral das formas de atuação em níveis de oportunidade de Produção mais Limpa nas seis empresas pesquisadas 


\section{LISTA DE SIGLAS E ABREVIAÇÕES}

ABIT Associação Brasileira das Indústrias Têxteis

ABRAPA Associação Brasileira dos Produtores de Algodão

ABRELPE Associação Brasileira de Empresas de Limpeza Pública e Resíduos Especiais.

ACIJA Associação Comercial e Industrial e Agropecuária de Jacutinga.

AlA Avaliação dos Impactos Ambientais

BNDES Banco Nacional de Desenvolvimento Econômico e Social

CEDBS Conselho Empresarial Brasileiro para o Desenvolvimento Sustentável

CETESB Companhia de Tecnologia de Saneamento Ambiental

CONAMA Conselho Nacional do Meio Ambiente

CNPML Centro Nacional de Produção mais Limpa

CNTL Centro Nacional de Tecnologias Limpas

CNUMAD Conferência das Nações Unidas sobre Meio Ambiente e Desenvolvimento

CP Centros de Pesquisa

DEPEC Departamento de Pesquisas e Estudos Econômicos

EIA Estudo de Impacto Ambiental

EPA United States Environmental Protection Agency - Agência de Proteção Ambiental dos Estados Unidos

IBGE Instituto Brasileiro de Geografia e Estatística

IEMI Instituto de Estudos e Marketing Industrial - LTDA

ITC Internacional Trade Center

LCA Life Cycle Assessment - Avaliação do Ciclo de Vida

MMR Manufatura da Malharia Retilínea

MR Malharia Retilínea 
MVM Manufatura do Vestuário de Moda

NCDENR N.C. Division of Pollution Prevention and Environmental Assistance

NCPC Centros Nacionais de tecnologias Limpas

ONU Organização das Nações Unidas

ONUDI Organização das Nações Unidas para o Desenvolvimento Industrial

P2 Prevenção da Poluição

$\mathrm{P}+\mathrm{L} \quad$ Produção mais Limpa

PCS Produção e consumo Sustentável

PNUMA Programa das Nações Unidas para o Meio Ambiente

PNRS Política Nacional de Resíduos Sólidos.

RAIS Relação Anual de Informações Sociais

RIMA Relatório de Impacto Ambiental

ROL Operação Líquida

SENAI Serviço Nacional de Aprendizagem Industrial

SGA Sistema de Gestão Ambiental

TQM Total Quality Management - Gestão da Qualidade Total

UNEP United Nations Envirommental Programe - Programa das Nações Unidas para o Meio Ambiente

VBPI Valor Bruto da produção Industrial

WBCSD World Business Council for Sustainable Development 
2.1 TECNOLOGIA FIM DE TUBO E PRODUÇÃO MAIS LIMPA …...............25

2.1.1 Definições e aplicações da Produção mais Limpa ..............................27

2.1.2 Centros nacionais de Produção mais Limpa .....................................32

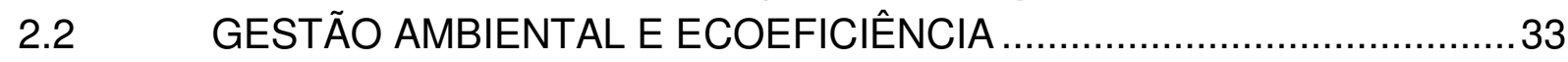

2.3 IMPACTOS AMBIENTAIS E CONSUMO SUSTENTÁVEIS ......................37

2.4 POLÍTICA NACIONAL DE RESÍDUOS SÓLIDOS (PNRS) .....................44

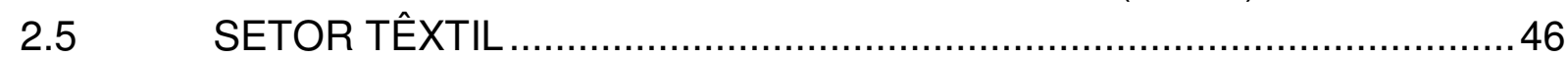

2.5.1 Manufatura do vestuário de moda (MVM) .....................................50

2.6 SETOR DE MALHARIA RETILÍNEA ……....................................52

2.6.1 Manufatura do Vestuário de Moda em Malharia Retilínea (MVMMR) . 53

$2.7 \quad$ IMPACTOS AMBIENTAIS DO SETOR TÊXTIL …….........................59

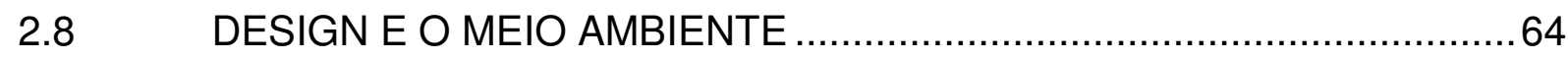

2.8.1 $O$ design na manufatura do vestuário de moda em malharia retilínea

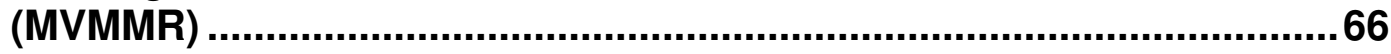

3 METODOLOGIA E PESQUISA

3.1 QUESTÃO FUNDAMENTAL NORTEADORA ....................................

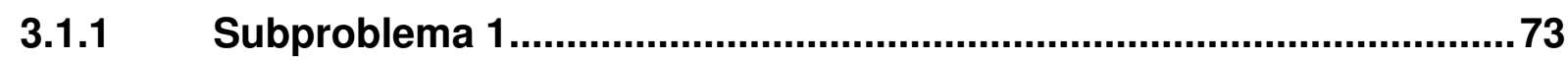

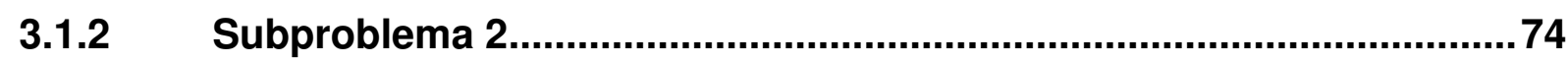

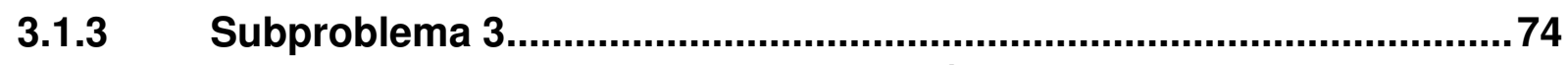

3.2 QUADRO DA ESTRUTURA METODOLÓGICA DA PESQUISA..............75

3.3 ASPECTOS GERAIS DA SELEÇÃO DA AMOSTRA ….......................77

3.3.1 Apresentação do perfil das empresas selecionadas ........................78

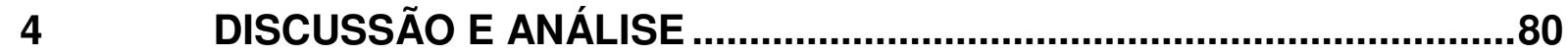

4.1 APRESENTAÇÃO E ANÁLISE DAS MALHARIAS ............................... 80

4.2 ANÁLISE COM RELAÇÃO AS EMPRESAS E A GESTÃO AMBIENTAL 90

4.3 ANÁLISE RELACIONADA A APROXIMAÇÃO DA PRODUÇÃO MAIS

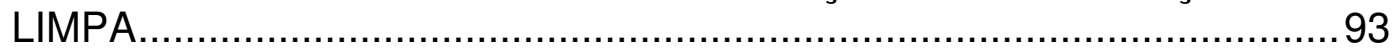

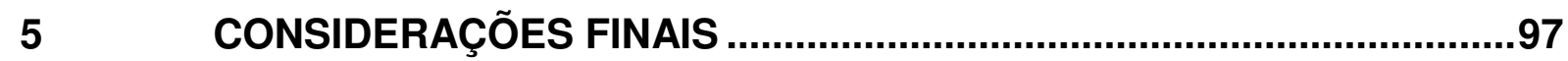

REFERÊNCIAS ...........................................................................102

APÊNDICE A - A situação da maquinaria Stoll .............................................109

APÊNDICE B - A situação da instituição "Mosteiro Santíssima Trindade"......119 APÊNDICE C - A situação da instituição de reciclagem ...................................125 


\section{INTRODUÇÃO}

O presente estudo está sendo realizado junto as linhas de pesquisa Sustentabilidade na Cadeia Têxtil e na Indústria da Moda e Processo produtivo na Manufatura do Vestuário de Moda (MVM), inserida no grupo de pesquisa Moda na Cadeia Têxtil devidamente cadastrada no CNPq. Este trabalho tem como proposta descrever a realidade ambiental, e como ocorre a gestão dos resíduos sólidos têxteis gerados pela produção industrial das empresas que desenvolvem e produzem vestuário a partir do processo de malharia retilínea no polo das malhas na região de Monte Sião, em Minas Gerais.

Muitos dos problemas ambientais ocorrem devido a modificações no meio ambiente, realizadas pelo homem a partir de extrações de recursos, emissões de diversos tipos de poluentes que vêm crescendo gradualmente ano após ano. Com isso é importante questionar como continuar usufruindo do ambiente natural sem destruir o solo e poluir os rios (BRAUNGART; MCDONOUGH, 2013; DIAS, 2014; GIANNETTI; ALMEIDA, 2006). Manzini e Vezzoli (2011) defendem que o impacto ambiental acontece devido às extrações e emissões, comprometendo nosso ecossistema. Vive-se um consumo crescente e a exploração dos recursos naturais ocorre devido ao crescimento tanto populacional quanto do consumo e da produção industrial.

Para o desenvolvimento de um produto, riscos ambientais devem ser considerados desde a fase inicial da pesquisa. Hoje se torna difícil gerar qualquer atividade de design sem pensar no ciclo de vida deste produto e o que ele causará ao meio social (MANZINI; VEZZOLI, 2011). Cardoso (2008) e Gwilt (2014) defendem no que diz respeito ao design do produto, este deve ser pensado de modo a satisfazer as necessidades de usabilidade tanto quanto seu desenvolvimento, utilizando materiais menos impactantes ao ambiente e que, ao mesmo tempo, prolonguem seu ciclo de vida.

O produto do vestuário de moda envolve toda a cadeia produtiva têxtil, desde 0 desenvolvimento de novas fibras, fios e tecidos, com o objetivo de atender um consumidor ávido por inovação nos vestuários de moda (MENDES, 2010). Os produtos fabricados em escala industrial são considerados versáteis, mas com o curto ciclo de vida geram alto índice de descarte. Devido à inconstância emocional do ser humano que o torna instável e emotivo, vivendo em uma sociedade em que os valores 
passam por constante transformação, surge uma inquietação em relação ao consumo exacerbado e consequente descarte destes produtos, sem uma preocupação ambiental (FLETCHER; GROSE, 2011; SALCEDO, 2014).

Segundo Berlim (2012) esta problemática ocorre devido ao curto ciclo de vida dos produtos de moda em função da instabilidade, diante das próprias características específicas que este produto possui. Mendes (2010) complementa esta afirmação e salienta que a obsolescência é uma característica deste produto que atende uma tendência de moda preestabelecida. Sendo assim, surge à necessidade de novos conceitos de design de moda, gerando novos produtos a cada estação climática, sem destacar a estratégia do Fast Fashion que estimula o consumo constante pela inovação de características específicas do produto, reduzindo ainda mais o ciclo de vida do produto de moda no mercado.

O setor têxtil produtivo do vestuário é cercado por elos importantes que compreendem todo um envolvimento da cadeia de fornecimento, assim para o desenvolvimento de um produto se faz necessário recorrer às fibras, fios, maquinarias especiais, tratamentos e uma série de recursos a fim de atender demandas. Um segmento que faz parte deste universo é a malharia retilínea, classificação da malharia por trama compondo este elo e, trazendo contribuição em diversos âmbitos não apenas na moda.

Supõe-se que, a malharia retilínea tem um processo produtivo que permite a utilização dos conceitos de design com foco na sustentabilidade possibilitando a redução dos descartes de fios e tecidos. Parte-se do pressuposto que algumas empresas deste setor agregam em seu processo produtivo, mesmo que informalmente, estratégias de implantação da Produção mais Limpa. Para Jabbour e Jabbour (2013), a Produção mais Limpa $(\mathrm{P}+\mathrm{L})$ tem o intuito de mostrar e quantificar a geração de resíduos sólidos, assim como efluentes líquidos e/ou emissões atmosféricas, além da intenção de alcançar alternativas que diminuam ou evitem o consumo de água, energia e matériasprimas.

No cenário da cadeia têxtil torna-se cada vez mais importante este estudo, pois, a água e a energia são primordiais para a fabricação de têxteis. Neste contexto faz-se significativo verificar como as empresas de malharia do polo industrial de Monte Sião, estão lidando com questões de conservação ambiental, levando em consideração 
aspectos que vão além do consumo de água e energia, até a importância de se verificar os resíduos sólidos têxteis, advindo deste processo de produção.

Com esta inquietação buscou-se aprofundar o estudo, baseando-se em uma metodologia de pesquisa, que tem como natureza uma abordagem qualitativa, a partir do método exploratório e descritivo e possui como delineamento os estudos de múltiplos casos em empresas do segmento, que há tempos estão se inserindo no desenvolvimento de produtos com o objetivo de reduzir, reaproveitar ou direcionar corretamente estes resíduos têxteis.

A partir da ótica dos malharistas colaboradores do polo industrial, e por meio de entrevistas e observações diretas dos processos nas empresas, procurou-se o entendimento de informações quanto à preocupação e percepção a respeito de aspectos ambientais.

Neste cenário surge à problemática "qual a realidade ambiental das malharias da região de Monte Sião em Minas Gerais?" Para responder esta pergunta, procurou-se entender melhor o tema e os fatos já estudados por meio de uma pesquisa bibliográfica e documental, completando com posterior estudo de múltiplos casos, em seis malharias, a fim de verificar a maior ou menor presença de preocupações da "Produção mais Limpa", tendo como foco principal os resíduos sólidos têxteis observando de maneira secundária a redução do uso de água e energia.

\subsection{JUSTIFICATIVA}

Segundo Berlin (2014), no último século o setor têxtil foi considerado um dos maiores poluidores. Além disso, Cardoso (2008) afirma que devido ao modelo consumista, já observa-se a contagem regressiva no esgotamento de alguns recursos naturais, e se fazem cada vez mais iminentes os estudos e planejamentos com relação à eliminação do desperdício.

Em razão destes problemas ambientais se faz relevante o estudo da redução de impactos ambientais do setor têxtil e vestuário, pois segundo Berlin (2014) a moda e a sustentabilidade tornam-se uma temática inesgotável com relação aos impactos ambientais causados pelo processo produtivo desordenado. 
De acordo com a Companhia de Tecnologia de Saneamento Ambiental (BASTIAN; ROCCO, 2009) devido à procura insistente por um melhor processo produtivo que exerça uma preocupação maior com relação às questões ambientais, o setor têxtil é o precursor com relação a práticas de produções mais limpas. Neste contexto os esforços crescem em direção a assegurar um processo produtivo visando a sustentabilidade.

Produções limpas, segundo Berlin (2014), são comumente encontradas atualmente nas indústrias, que para SENAI (2007), se relacionam a acertos no desenvolvimento, de modo a permitir a diminuição dos resíduos gerados e o lançamento de gases.

Segundo Abit (2015) verifica-se que a malharia retilínea é um segmento do setor têxtil que tem passado por grandes inovações, tanto em seu processo produtivo, quanto em melhorias voltadas para matérias-primas e maquinários.

Segundo Fletcher e Grose (2011), embora existam sistemas para se calcular os cortes dentro das confecções pode-se dizer que o desperdício ainda é muito grande, visto que para se fabricar um tecido, os recursos naturais necessários são muitos e então retalhos de tecidos descartados é um fator existente na cadeia de desenvolvimento a ser analisada.

O setor têxtil é pioneiro com relação as práticas de Produção mais Limpa, isto porque objetiva sempre a melhoria em seu processo produtivo onde as questões ambientais são de grande relevância. Neste sentido tem sido direcionados esforços para a redução do consumo de água e de energia em todas as etapas da cadeia têxtil (BASTIAN; ROCCO, 2009).

Em relação a cadeia têxtil há poucas bibliografias apresentando pesquisas realizadas e referente a sustentabilidade no ambiente produtivo das malharias retilíneas.

De acordo com os contextos acima, são importantes os levantamentos de estudos no setor de malharia retilínea visto que, o mesmo apresenta ausência de pesquisas, priorizando um estudo minucioso no que diz respeito às possibilidades de produções limpas destinadas a este segmento.

A presente pesquisa baseia-se em pressupostos de ser um tema relevante para 0 campo de têxtil e moda, pois este é um aspecto, sobretudo com relação à existência da realidade ambiental tanto das implicações de consumo de recursos quanto processo de fabricação do material têxtil realizado em um polo industrial. 
Pressupõe-se também que exista tratamento de nível adequado para os resíduos sólidos têxteis encontrados, sejam estes realizados de modo interno ou externo no processo produtivo das malharias.

\subsection{OBJETIVOS}

Este estudo teve como objetivo geral realizar uma investigação da realidade ambiental da produção industrial de malharias na região de Monte Sião, Minas Gerais.

A partir do objetivo geral a presente pesquisa tem como objetivo específico uma investigação qualitativa associativa de dados sobre os três subproblemas a seguir:

- investigar à maior ou menor presença de preocupações de "Produção mais Limpa", sobretudo quanto à geração e redução do descarte dos resíduos sólidos têxteis.

- identificar à maior ou menor presença de preocupações de "Produção mais Limpa", em termos da redução da utilização de água

- identificar à maior ou menor presença de preocupações de "Produção mais Limpa", em termos da redução da utilização de energia.

\subsection{ESTRUTURA DA PESQUISA}

A presente dissertação encontra-se dividida e estruturada em cinco capítulos, como segue.

O capítulo 1, já exposto é o de caracterização da pesquisa, apresentando a introdução que contempla sobre realidade ambiental na manufatura do vestuário de moda, exibe a questão fundamental norteadora da pesquisa, conceitos e termos básicos característicos da pesquisa, justificativa, além dos objetivos geral e específicos e os pressupostos.

O capítulo 2, fundamentação teórica, tem como proposta apresentar pesquisas, teorias e conceitos descritos por pesquisadores e autores sobre a cadeia têxtil e a 
indústria de moda, e impactos causados por seu processo produtivo, além do estudo da estratégia de Produção mais Limpa e suas aplicações bem como outras seções abordadas dentro deste contexto.

O capítulo 3 é composto por métodos e técnicas de pesquisa, onde apresenta-se a questão fundamental, separação dos subproblemas, tipos de dados, fontes, técnica de coleta, técnica de tratamento necessários para responder cada subproblema, finalizando com indagações exploratórias.

O capítulo 4 encontra-se subdividido na análise dos resultados concernentes quanto à redução do consumo de água e energia bem como redução da produção de resíduos sólidos, por meio dos dados qualitativos que, por fim possibilitaram uma discussão correlacionando-os com a teoria estudada.

O capítulo 5 traz as considerações finais a respeito das análises dos resultados da pesquisa, verificando soluções para a mitigação dos impactos causados pela manufatura do vestuário de moda em malharia retilínea e recomendações futuras. 


\section{FUNDAMENTAÇÃO TEÓRICA}

Neste capitulo serão abordados os conceitos teóricos obtidos por meio da pesquisa bibliográfica, com a finalidade de proporcionar maior conhecimento do tema estudado, dada à importância da gestão de resíduos têxteis na Manufatura do Vestuário de Moda em Malharia Retilínea por meio da estratégia de Produção mais Limpa.

Com o propósito de aumentar o conhecimento no assunto, bem como fundamentar o levantamento bibliográfico e documental do presente estudo, e objetivando uma contribuição para análise dos resultados e escopo da pesquisa, foi realizada uma pesquisa bibliométrica em bases de dados relevantes como: Scopus, Web of Science, IEEE Xplore (IEEE). Utilizando palavras chave no inglês que tratam do tema central da pesquisa, estipulando um recorte que se inicia com publicações de 2012 a julho de 2016.

Nesse trabalho descreve-se uma revisão bibliométrica como método de pesquisa, com um panorama geral sobre publicações referentes à Cleaner Production e direcionando essa pesquisa para a Cadeia Têxtil, inserindo a esse contexto palavraschaves como Solid waste, Clothing, e Knitting.

$\mathrm{Na}$ base Scopus, como palavra-chave utilizou-se o termo Cleaner Production para busca em título (Title), resumo (Abstract) e Palavras-chave (Keywords). Nessa primeira etapa a busca ocorreu sem outras delimitações para verificar o panorama de abrangência das publicações abordando Produção mais Limpa. Obteve-se o resultado de 734 artigos.

Utilizando o descritor Cleaner Production and Textile obteve-se um total de 70 artigos. Realizando um filtro quanto a estas palavras-chaves por tipo de documento em artigo, artigo impresso e conferência, foram encontrados 59 artigos. Usando as palavraschaves relacionadas ao tema: Environmental impact, Manufacture, Life cicle, life Cycle Assessment, Life Cicle Assessment (LCA) em Textile, Textiles, Textile Industry obteve-se um registro de 26 artigos.

A partir dos 26 fechou-se em Solid Waste resultando somente quatro publicações, e partindo novamente dos 26 usou-se Clothing, obtendo-se o resultado de outras quatro publicações e, dentro das 26, por fim, o termo Knitthing com apenas uma publicação. 
Isso se fez necessário porque, a partir do fechamento da palavra, Solid Waste, mais nenhum outro artigo foi encontrado abrangendo as palavras Clothing ou Knitthing.

Com o mesmo recorte dos últimos cinco anos, aplicou-se na base de dados Web of Science, usando a palavra-chave Cleaner Production e foram encontradas 555 publicações. Para Cleaner Production and Textile registraram-se 40 artigos. Acrescentando-se palavras-chaves and Textiles and Solid waste obteve-se um artigo. Para a busca and Clothing, duas publicações foram obtidas, e finalizando uma publicação com a palavra Knitthing.

Seguindo para a Base de dados IEEE EXPLORE, abordando o mesmo período e usando a palavra-chave Cleaner Production foram encontradas 645 publicações (Full Text \& Metadata). Para Cleaner Production and Textile registraram-se 49 artigos. A partir desse resultado de 49 publicações, usando palavras-chaves Cleaner Production and Textiles e Solid waste, obtiveram-se seis artigos. Para a busca com Clothing foram 11 publicações obtidas, e por fim com a palavra Knitthing foi registrada uma publicação.

A pesquisa bibliométrica, além de contribuir com base teórica para este estudo, também mostrou a ausência de trabalhos sobre o tema de Produção mais Limpa no setor de malharia retilínea, o que justifica o empenho em levantar dados e contribuir com publicações cientificas a este respeito. Para esta pesquisa utilizou-se os dois artigos encontrados que mais se identificavam com a proposta da presente pesquisa. Na primeira seção deste capitulo serão evidenciados os conceitos sobre a tecnologia de fim de tubo e a Produção mais Limpa, suas definições e aplicações bem como serão apresentados os centros nacionais de Produção mais Limpa.

Os três tópicos seguintes tratam da gestão ambiental, ecoeficiência, abordando também os impactos ambientais, produção e consumo sustentável, exibindo uma síntese com relação a política nacional dos resíduos sólidos bem como a caracterização e classificação dos resíduos.

As seções 4 e 5 explanam sobre o setor têxtil e o segmento de malharia retilínea evidenciando a manufatura do vestuário de moda, fazendo uma apresentação do processo produtivo e suas especificidades. 
As seções finais referem-se aos impactos ambientais do setor têxtil, assim como, tratam design e o meio ambiente de modo a explanar o design na manufatura do vestuário de moda na malharia retilínea.

\subsection{TECNOLOGIA FIM DE TUBO E PRODUÇÃO MAIS LIMPA}

É conhecido como fim de tubo a denominação do tratamento de resíduos sólidos, efluentes líquidos e emissões atmosféricas adotadas pelas empresas na fase final de seus processos, com o intuito de acatar as normas definidas pelos órgãos ambientais (CEBDS, 2008).

O modelo inicial de prevenção oferece resultado benéfico para distintos meios ambientais, visando a redução ou eliminação na fonte das emissões potencialmente perigosas, poluidoras ou tóxicas. Já o modelo fim-de-tubo contribui para um determinado tipo de ambiente e a abordagem deste modelo realimenta o mercado de resíduos perigosos e tóxicos, ao inverso do princípio da prevenção, que os extingue (FURTADO; FURTADO, 1998).

Quadro 1 - Diferenças entre tecnologias fim de tubo e Produção mais Limpa.

\begin{tabular}{|c|c|}
\hline TECNOLOGIA FIM DE TUBO & PRODUÇÃO MAIS LIMPA \\
\hline $\begin{array}{l}\text { Como tratar os resíduos e as emissões } \\
\text { existentes? } \\
\text {...Pretende reação. }\end{array}$ & $\begin{array}{l}\text { De onde vêm os resíduos e as emissões? } \\
\text {...Pretende ação. }\end{array}$ \\
\hline Geralmente leva a custos adicionais. & Pode ajudar a reduzir custos. \\
\hline $\begin{array}{l}\text { Os resíduos, efluentes e emissões limitadas } \\
\text { através de filtros e técnicas de tratamento; } \\
\text { Soluções de fim de tubo; Tecnologia de reparo; } \\
\text { Estocagem de resíduos. }\end{array}$ & $\begin{array}{l}\text { Prevenção de resíduos e emissões na fonte; } \\
\text { Evita processos e materiais potencialmente } \\
\text { tóxicos. }\end{array}$ \\
\hline $\begin{array}{l}\text { Proteção ambiental entra depois de } \\
\text { desenvolvimento de produtos e processos. }\end{array}$ & $\begin{array}{l}\text { Proteção ambiental entra como parte integral do } \\
\text { design do produto e da engenharia de processo. }\end{array}$ \\
\hline $\begin{array}{l}\text { Problemas ambientais são resolvidos a partir de } \\
\text { um ponto de vista tecnológico. }\end{array}$ & $\begin{array}{l}\text { Tenta-se resolver os problemas ambientais em } \\
\text { todos os níveis/em todos os campos. }\end{array}$ \\
\hline $\begin{array}{l}\text { Proteção ambiental é um assunto para } \\
\text { especialistas competentes. }\end{array}$ & Proteção ambiental é tarefa de todos. \\
\hline ...é trazida de fora. & $\begin{array}{l}\text {..é uma inovação desenvolvida dentro da } \\
\text { empresa. }\end{array}$ \\
\hline ...aumenta o consumo de material e energia. & ...reduz o consumo de material e energia. \\
\hline Complexidade e riscos aumentados. & Riscos reduzidos e a transparência aumentada. \\
\hline $\begin{array}{l}\text { Proteção ambiental desce para preenchimento } \\
\text { de prescrições legais. }\end{array}$ & Riscos reduzidos e transparência aumentada. \\
\hline $\begin{array}{l}\text {...resultado de um paradigma de produção do } \\
\text { tempo em que os problemas ambientais não } \\
\text { eram conhecidos. }\end{array}$ & $\begin{array}{l}\text {...abordagem que pretende criar técnicas de } \\
\text { produção para o desenvolvimento sustentável. }\end{array}$ \\
\hline
\end{tabular}

Fonte: CNTL (2003). 
O Quadro 1 faz um comparativo entre a Produção mais Limpa e a tecnologia de fim de tubo. Segundo Furtado e Furtado (1998) a produção limpa é mais ampla, indo além do intuito da auditoria de redução de resíduos e dos procedimentos previstos nas normas técnicas, para incorporar fatores jurídicos, políticos e sociais; estabelecendo uma visão mais abrangente das relações entre o sistema de produção industrial e o ambiente.

Para Amato Neto (2011), a Produção mais Limpa aborda de modo mais radical, principalmente quando se trata de produção industrial, alterando os padrões de produção, bens e serviços, opondo-se ao modelo de "fim de tubo" que não leva em consideração resguardar recursos naturais. Assim, a nova abordagem de $P+L$ traz uma preocupação com a concepção do produto desde sua criação até o seu descarte final, a Produção mais Limpa lida com a trajetória de "berço ao berço" pensando em questões após o uso, como reciclagem e a reutilização de maneira a reduzir a perda de materiais e energia.

$\mathrm{Na}$ Figura 1 pode-se verificar abordagens com relação a tecnologia de fim de tudo, em que o foco está na gestão dos resíduos, visto que na Produção mais Limpa o foco encontra-se nos processos produtivos e no ciclo de vida.

Figura 1 - Evolução das empresas rumo a Produção mais Limpa.

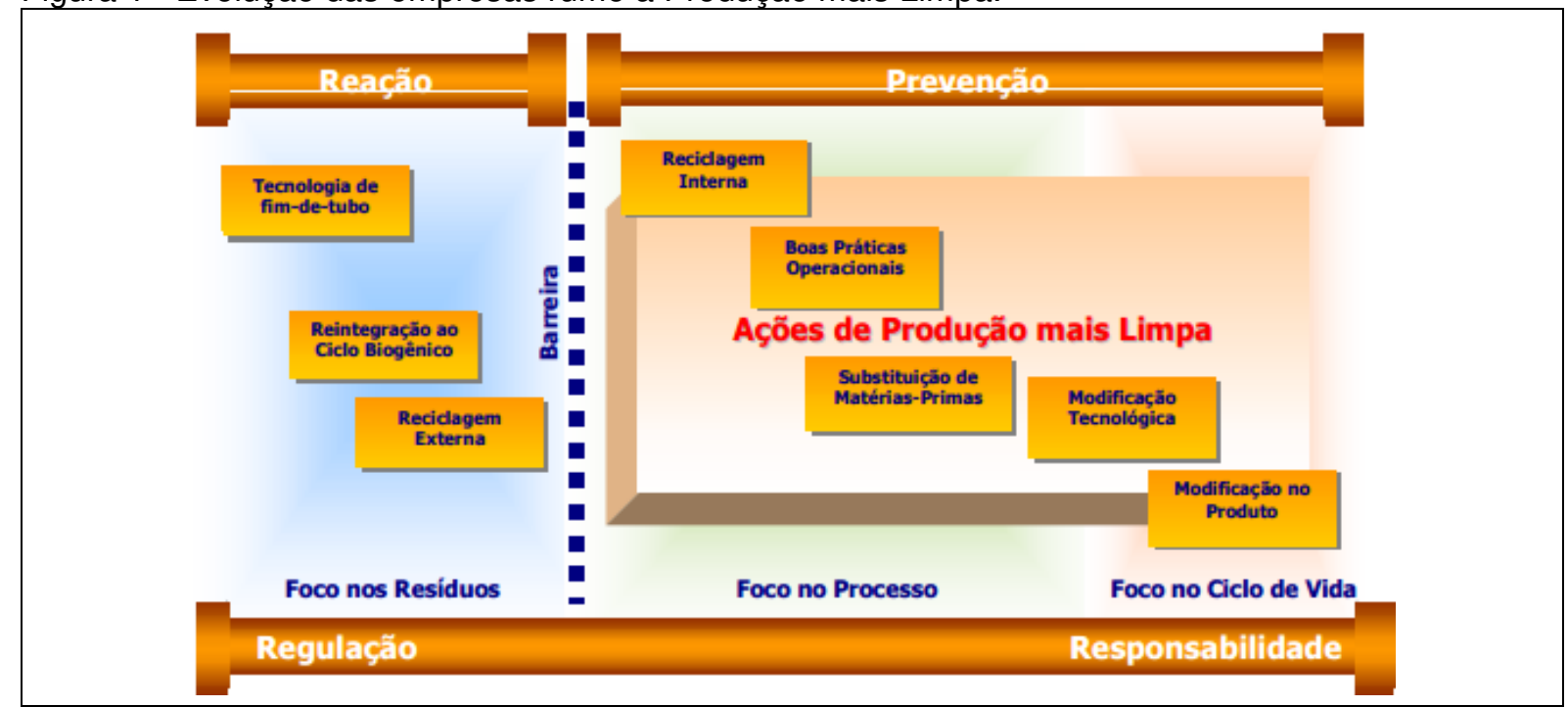

Fonte: CNTL (2003).

A abordagem de prevenção traz uma contribuição de modo mais efetivo para solução do problema ambiental. Embora seja mais complicada, ela exige alteração no processo de produção e/ou a instalação de novas tecnologias, concedendo uma 
diminuição contínua dos custos gerais, incorporando lucros econômicos, ambientais e de saúde ocupacional (CNTL, 2003).

\subsubsection{Definições e aplicações da Produção mais Limpa}

Para Giannetti e Almeida (2006, p. 12) "Produção mais Limpa é a aplicação contínua de uma estratégia integrada de prevenção ambiental a processos, produtos e serviços para aumentar a eficiência de produção e reduzir os riscos para o ser humano e o ambiente".

Criada para minimizar problemas ambientais, a Produção mais Limpa é utilizada como uma ferramenta que visa a redução da poluição, no qual gestores de empresas buscam soluções que orientem a gestão dos recursos naturais objetivando diminuir a emissão e o desperdício durante a realização de uma tarefa ou produto e não tratá-lo depois que o mesmo já tenha sido gerado (BERKEL, 2000 apud ANACLETO et al., 2012).

Para EPA (2011) e Jabbour e Jabbour (2013) a Produção mais Limpa tem como intuito mostrar e quantificar a geração de resíduos sólidos assim como efluentes líquidos e/ou emissões atmosféricas com a intenção de alcançar alternativas que diminuam ou evitem o consumo de água, energia e matérias-primas.

O Gráfico 1 mostra os níveis de oportunidade de Produção mais Limpa, onde tem-se três níveis de divisão, sendo que os dois primeiros (Redução na fonte e reciclagem interna) fazem parte do processo de minimização de resíduos e emissões e o terceiro (reciclagem externa e ciclos biogênicos) estão inseridos no reuso de resíduos, efluentes e emissões (SENAI, 2007). 
Gráfico 1 - Níveis de oportunidade de Produção mais Limpa.

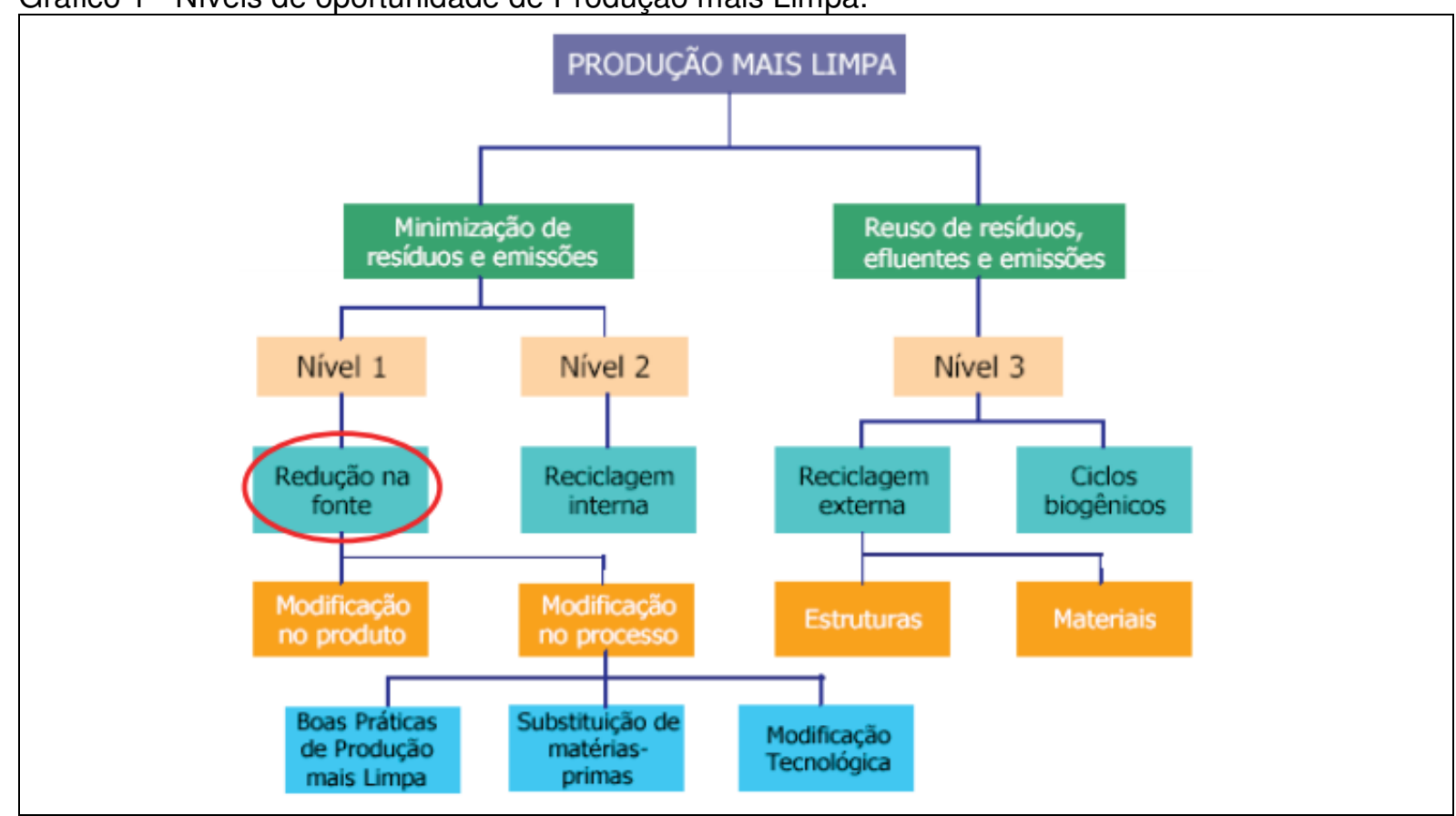

Fonte: SENAI (2007)

Desde a década de trinta, movimentos relacionados com as questões ambientais e sua gestão são o foco para direcionar a poluição e seus malefícios. Porém, apenas na década de setenta são criados os programas de prevenção à poluição e na década de noventa é gerada uma lei para a prevenção da mesma de modo a estimular a redução dos impactos ambientais (COBRA, 2015).

O Gráfico 2 apresenta a cronologia da criação e implementação da ferramenta Produção mais Limpa. 
Gráfico 2 - Desenvolvimento histórico da Produção mais Limpa.

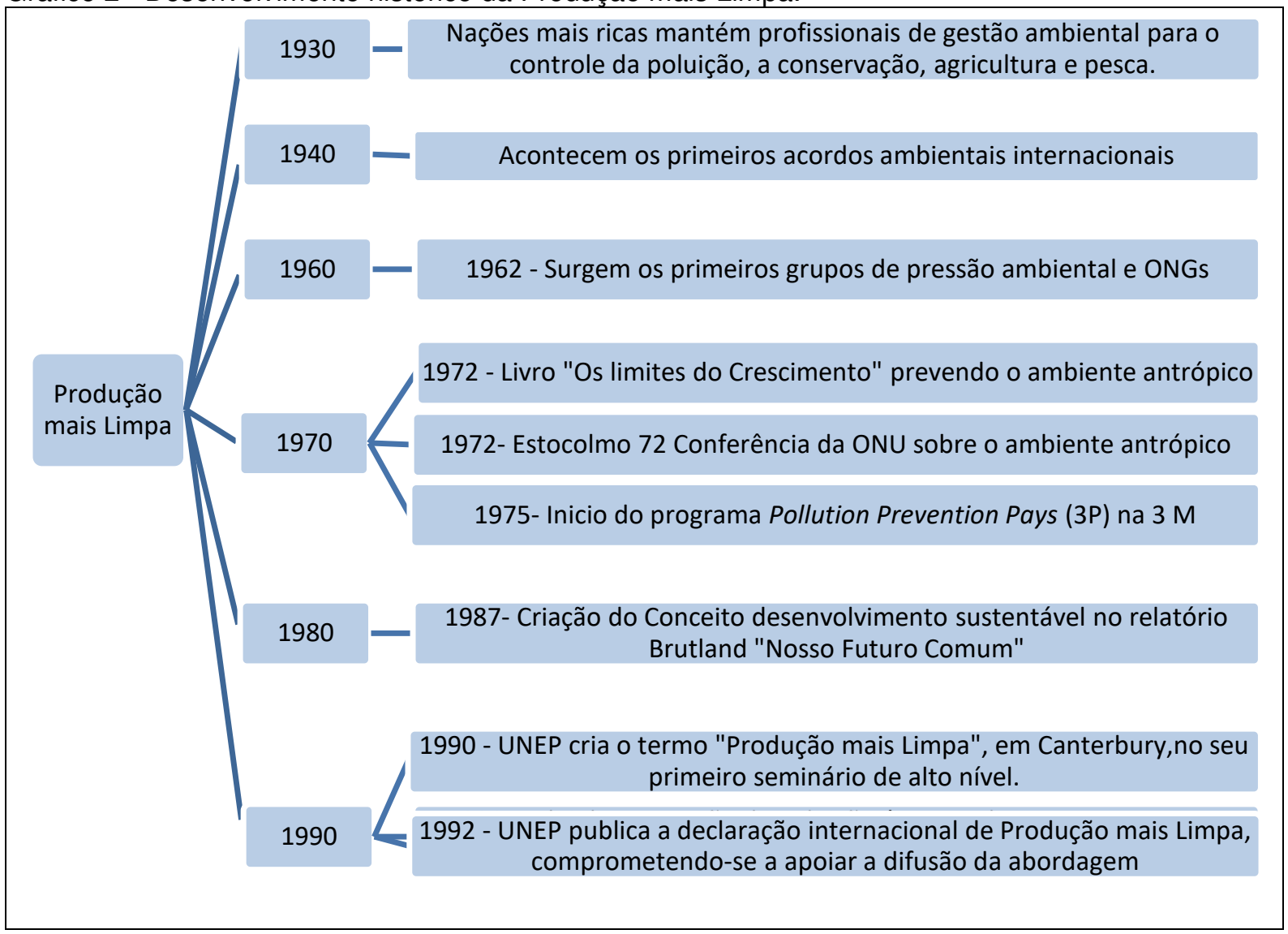

Fonte: adaptado de Cobra (2015).

Geralmente o início da Produção mais Limpa nos processos se dá com a aplicação do "bom senso" que com o tempo se desenvolve até se incorporar em seus conceitos e gestão da administração. É relevante dizer que a Produção mais Limpa é um processo de gestão que abraça diferentes fases da empresa, passando da alta diretoria aos diversos colaboradores. Ocupa-se não somente de mudanças empresariais, mas também de técnicas operacionais. Todavia cuida de uma mudança cultural que precisa de comunicação para ser expandida, a fim de alcançar simultaneamente benefícios ambientais e econômicos na gestão dos processos (BASTIAN; ROCCO, 2009).

A Produção mais Limpa possui algumas razões que norteiam a sua implantação, como: um custeio menor da produção, disposição final, cautela com a saúde e um meio ambiente mais limpo. Ainda traz uma melhoria na eficiência do processo e na qualidade do produto, influindo na contribuição inovadora industrial e na competitividade. Bem como diminui os riscos aos trabalhadores, aos consumidores dos produtos e a comunidade, incluindo as próximas gerações. Por fim, proporciona 
a melhoria no conceito público das corporações trazendo benefícios sociais e econômicos intangíveis (BASTIAN; ROCCO, 2009)

A justificativa do investimento em Produção mais Limpa se deve ao fato desta vir a fortificar economicamente a indústria, por meio da prevenção da poluição, impulsionado pelo anseio da contribuição para com uma situação ambiental melhor de determinada região (SENAI, 2007).

A partir do momento que a empresa implanta o modelo de Produção Limpa (PL), segundo Furtado (2005) é possível que a mesma tenha a capacidade de solucionar problemas como: respeito à cidadania; contribuição para coesão social; utilização de materiais renováveis; redução do uso de energia, impactos negativos e consumo de materiais; minimização de custos e investimentos; aumento da vida útil do produto; gestão responsável de acidentes internos e externos; prevenção de impactos globais; destinação de descarte e prevenção de penalidades.

Mostram-se na Figura 2 as possibilidades de interação entre empresas de maneira que uma possa utilizar como matéria-prima o que é considerado descartado pela outra.

Figura 2 - Representação da interação entre os fluxos de diversos sistemas.

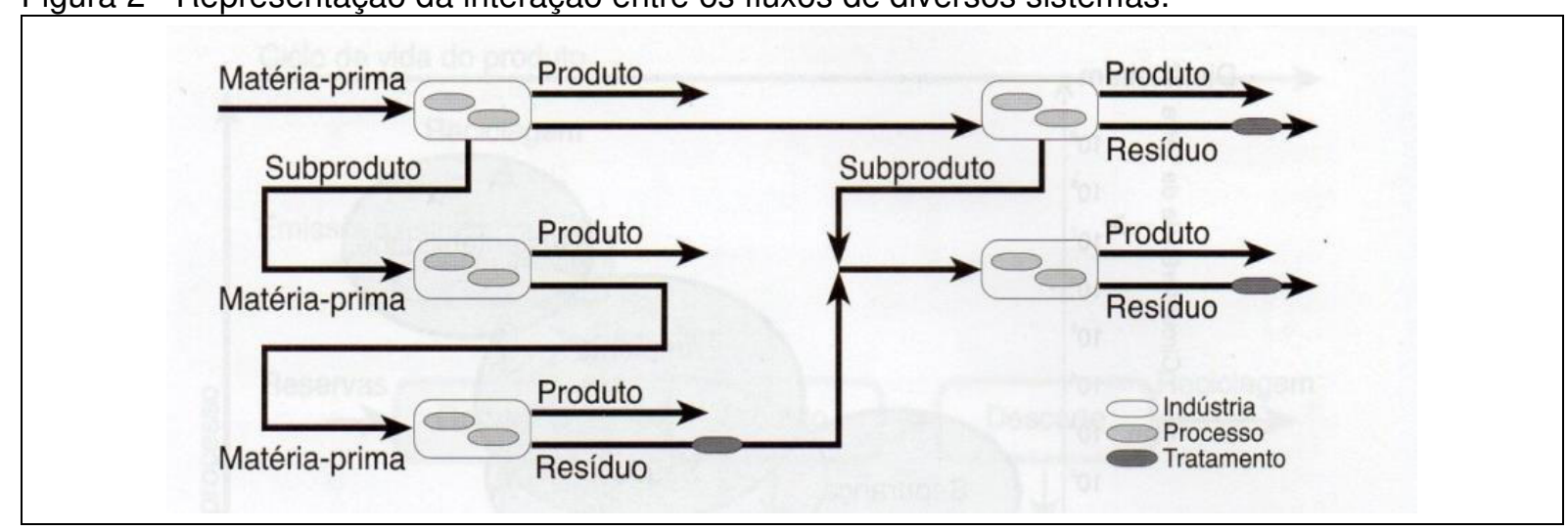

Fonte: Giannetti e Almeida (2006).

Furtado (2005) afirma que mudanças culturais e a capacidade de aprendizagem interna são os principais desafios para a inserção das questões socioambientais nos negócios das empresas.

Na Figura 3, segundo Giannetti e Almeida (2006, p. 14), práticas de Produção mais Limpa 
dentro do processo antes do descarte, resultando em melhor aproveitamento de matéria-prima e energia.

Figura 3 - Representação de uma empresa onde são aplicados conceito de Produção mais Limpa.

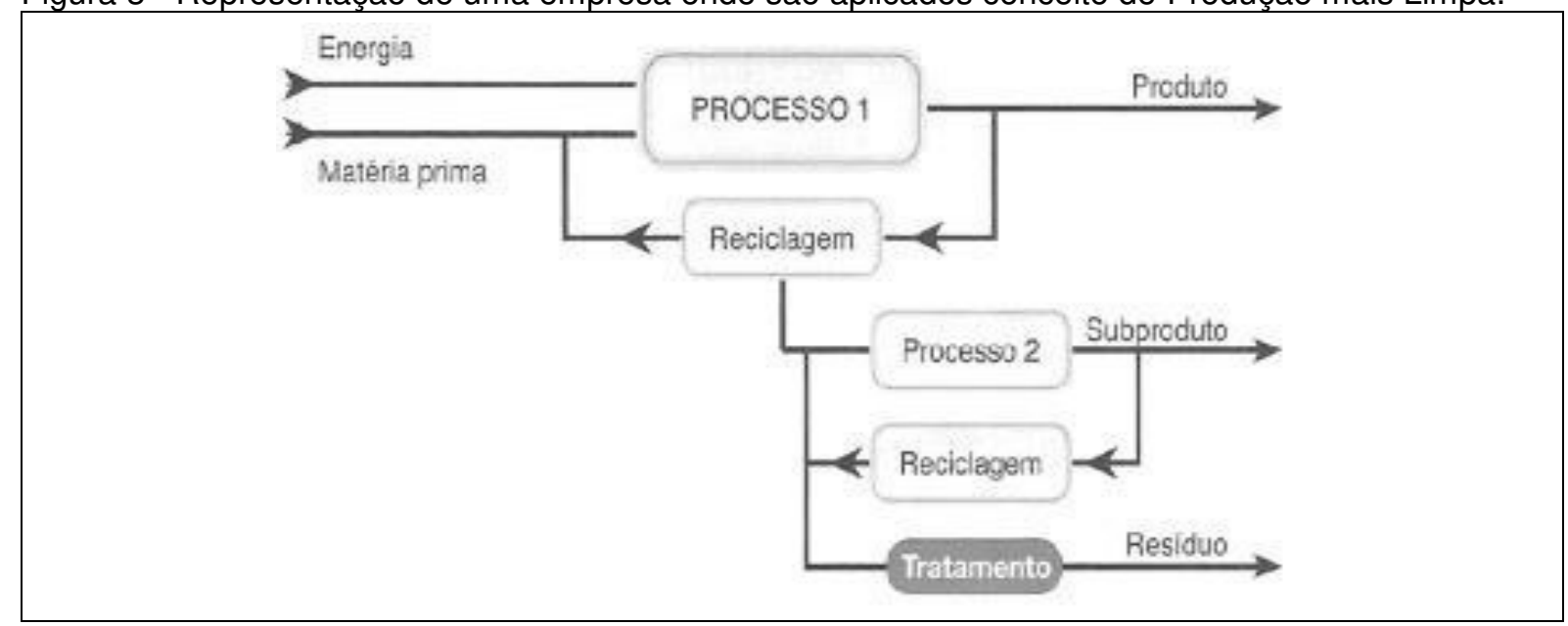

Fonte: Giannetti e Almeida (2006).

Baseando-se em problemáticas ambientais já conhecidas, o programa da Produção mais Limpa tem como intuito a verificação das atividades de uma empresa assim como seu processo de produção, levantando estudos da problematização em relação à utilização de materiais e energia (SENAI, 2007). A Produção mais Limpa compreende uma variedade de práticas, estratégias e condutas econômicas tanto quanto ambientais e técnicas, que visem a diminuição de poluentes ao meio ambiente através de atividades preventivas e alternativas, fazendo com que se pense em reutilizar e reciclar (BASTIAN; ROCCO, 2009).

Senaga (2010) discorre sobre Produção mais Limpa e seus benefícios em empresas de grande, médio e pequeno porte. Após historiar brevemente a evolução da conduta ambiental empresarial afirma que a abordagem tradicional embasada no controle corretivo vem sendo ultrapassada por conta de limitações e substituída pela abordagem preventiva que se mostra mais eficiente, uma vez que busca causalidades dos problemas ambientais. Senaga (2010) ainda completa que o êxito da Produção mais Limpa é justificado por ser mais eficiente, diminuindo o uso de matérias-primas, água e reduzindo a geração de resíduos, entre outros, além de fazer uso de materiais menos tóxicos.

É evidente que os aperfeiçoamentos ambientais atingidos mundialmente através de programas de Produção mais Limpa e ecoeficiência estão mostrando um contraste com relação ao crescimento do consumo de produtos e serviços, além do aumento da população (CETESB; PNUMA, 2005). 
Segundo CETESB e PNUMA (2005) as empresas possuem uma tendência em perceber como "ambientalistas" os conceitos integradores focados em Produção mais Limpa e ecoeficiência. De acordo com Giannetti e Almeida (2006, p. 17) a ecoeficiência é definida pela World Business Council for Sustainable Development (WBCSD) "pelo trabalho direcionado à minimizar impactos ambientais, devido ao uso minimizado de matérias-primas: produzir mais com menos".

\subsubsection{Centros nacionais de Produção mais Limpa}

De maneira geral o programa de $P+L$ foi realizado com sucesso, pois a maioria das expectativas foram cumpridas, com satisfação e ocorreram até atividades inesperadas, tal como a criação de redes em nível regional e depois nacional. Das perspectivas não atingidas tem-se a implementação de centros de produção em parceria com instalações tecnológicas de controle de poluição para verificação da qualidade ambiental. $O$ que se pretende é sanar os problemas com relação à degradação do meio ambiente em sua totalidade e ampliar o programa de maneira significativa (LUKEN et al., 2016).

O objetivo dos departamentos da rede SENAI de Meio Ambiente é prosseguir com ações técnicas que têm o intuito de visualizar o sucesso do serviço e incentivar medidas de fornecimento e desdobramentos tecnológicos no setor ambiental em todo Brasil. Existem 24 departamentos regionais participantes, são eles: Amazonas, Alagoas, Bahia, Ceará, Distrito Federal, Espírito Santo, Goiás, Mato Grosso, Maranhão, Mato Grosso do Sul, Minas Gerais, Pará, Paraíba, Paraná, Pernambuco, Piauí, Rio de Janeiro, Rio Grande do Norte, Rio Grande do Sul, Rondônia, Roraima, Santa Catarina, Sergipe e Tocantins (SENAI, 2012).

O programa teve início com quatro serviços principais que eram: 1. A conscientização e criação, divulgação da informação que se dava por meio da distribuição de materiais, realização de seminários e oficinas de conscientização, sendo estes colocados em primeiro lugar para governo e setor privado; 2. Formação: um grupo de peritos nacionais deveria ser treinado para ajudar com a implementação do Centro de Produção (CP); 3. Avaliação da produção no local e assistência técnica: monitoramento que visa à organização de se implantar o $\mathrm{CP}$, adequando-se a seus 
produtos, serviços e processos em relação a competências, sistemas de gestão e tecnologia; 4. Política de conselhos: assistência para verificação e adaptação de estratégias e políticas para promover a inserção do $\mathrm{CP}$, ligação com o governo e outros (LUKEN et al., 2016).

Porém, anteriormente a esta data, muito já se discutia no país com relação ao meio ambiente. Têm-se em Dias (2014) e em Luken et al. (2016) dados referentes a "Conferência das Nações Unidas sobre Meio Ambiente e Desenvolvimento (CNUMAD)" que ocorreu no Rio de Janeiro em 1992. A conferência teve como foco a assinatura de cinco documentos direcionados a discussões referentes ao meio ambiente e suas colocações para os anos seguintes. De acordo com Cardoso (2008) o movimento ambientalista começou a tomar forma e foi se mostrando no que conhecemos atualmente. Tornou-se consolidado do ponto de vista institucional, a partir da segunda conferência da ONU em 1992 no Rio de Janeiro, tornando-se assim parte do cenário político mundial.

Nos últimos, anos foi investido treinamento extensivo e aperfeiçoamento para os profissionais nos CNTL's brasileiros. Tem-se trocado informações e experiências dentro da América Latina, com a Argentina e México e no Equador há projetos de capacitação (LUKEN et al., 2016).

\subsection{GESTÃO AMBIENTAL E ECOEFICIÊNCIA}

Para Barbieri (2007) gestão ambiental é uma expressão utilizada na maioria dos projetos relacionados a todas as questões voltadas ao meio ambiente. Em sua concepção, as atividades governamentais estão para combater a falta de recursos. Três dimensões fazem parte, no mínimo, de qualquer objetivo de gestão ambiental, sendo a primeira a dimensão espacial, que diz respeito ao setor onde se pretende realizar as ações com eficácia, a dimensão temática é a que vincula questões ambientais as quais serão destinadas através das ações, a dimensão institucional que tem como referência os agentes e suas iniciativas de gestão.

As práticas de gestão ambiental em empresas estão cada vez mais abordadas, discutidas tanto para cidadãos comuns como para governantes, empresários, estudantes e funcionários. Esta mudança ocorre devido à forma como o homem 
gerencia e planeja produtos, bens e serviços (JABBOUR; JABBOUR, 2013). Braungart e Mcdonough (2013) completam ainda que a vida do meio ambiente está diretamente ligada a diversidade e que quando há harmonia entre os processos é possível produzir e manter o ambiente saudável, pois quanto mais se tira do ecossistema "sem base" menos ele poderá lhe proporcionar depois. Em contrapartida quando se realizam produções conscientes o sistema continua a produzir sem se danificar.

A sociedade uma vez estando consciente das questões ambientais, exigirá mais das organizações no que se refere a desempenho ambiental, tornando-se importante e reforçada a gestão ambiental organizacional (JABBOUR; JABBOUR, 2013). Percebese uma semelhança entre os procedimentos de gestão ambiental em diversos casos. Assim, de uma área para outra são necessárias apenas alguns acertos. Estas alterações baseiam-se na mudança das metodologias que melhoram cada vez mais, facilitando a compreensão das análises e planejamento das ações Floriano (2007). Considera-se, segundo Jabbour e Jabbour (2013), quatro recentes eras da conscientização ambiental como pode ser analisado no Quadro 2.

Quadro 2 - Eras da conscientização ambiental.

\begin{tabular}{|l|l|}
\hline \multicolumn{1}{|c|}{ ANO } & \multicolumn{1}{c|}{ FATO } \\
\hline $\mathbf{1 9 7 0}$ & $\begin{array}{l}\text { No início desta década ocorreu 10 United Nation Environmental Conference; } \\
\text { Apareceram as primeiras agências de regulação ambiental que induziam } \\
\text { adequações ambientais nas corporações; }\end{array}$ \\
\hline $\mathbf{1 9 8 0}$ & $\begin{array}{l}\text { É marcada uma conscientização ambiental maior, devido a acidentes ambientais } \\
\text { trágicos de grande porte; }\end{array}$ \\
\hline $\mathbf{1 9 9 0}$ & $\begin{array}{l}\text { Na metade desta década se dá o surgimento dos termos como perspectiva } \\
\text { ambiental, produtividade ambiental. Propostas onde são beneficiadas tanto } \\
\text { empresas como meio ambiente através da gestão ambiental; } \\
\text { Criação do termo ecoeficiência. }\end{array}$ \\
\hline $\mathbf{2 0 0 0}$ & $\begin{array}{l}\text { Onde a gestão ambiental ocupa primeiro posto sendo um dos principais intuitos das } \\
\text { organizações; }\end{array}$ \\
\hline
\end{tabular}

Fonte: adaptado de Jabbour e Jabbour (2013).

Para se adotar qualquer modelo de gestão é preciso fazer uso de ferramentas para atingir o propósito característico em relação ao ambiente. Alguns instrumentos que as empresas podem usufruir para atingir o foco ambiental são: avaliação do ciclo de vida, estudo dos impactos ambientais, sistema de gestão ambiental (BARBIERI, 2007). Milan, Vittorazzi e Reis (2010) defendem que além de serem considerados princípios de gestão ambiental, minimizar custos com a eliminação de desperdícios e de resíduos, aperfeiçoar tecnologias limpas e reciclar equivalem também a condições de um mercado próspero. 
Alcançar melhores padrões de qualidade de vida utilizando menos recursos naturais é o principal desafio nos próximos anos. Faz-se necessária uma transformação na economia que minimize o uso de recursos naturais para se alcançar um desenvolvimento sustentável ao longo do ciclo de vida dos produtos e serviços. É necessário incrementar sua produtividade, e desta maneira, gerar uma redução nos impactos ambientais e nos diversos segmentos econômicos. Neste contexto, afirmase que a ecoeficiência proporcionará profundas alterações tecnológicas, mesmo que estas não sejam suficientes, porém constituem em uma necessidade para se alcançar a sustentabilidade (DIAS, 2014).

A ecoeficiência traz uma indicação de rompimento entre o crescimento econômico e o impacto ambiental, o que seria obtido através da diminuição no uso de energia e reservas naturais e pelo crescimento da eficiência dos processos. Compreende-se como uma filosofia proativa o que pode acarretar vantagens competitivas, isso quando a empresa necessita trabalhar com regulamentações ambientais mais rígidas, comunidades que pressionam por uma melhoria no desempenho ambiental, aumento da demanda por produtos e serviços ambientalmente amigos e atingir a padrões internacionais (GIANNETTI; ALMEIDA, 2006).

Pode a ecoeficiência determinar muitas maneiras de se beneficiar, incluindo os sistemas de inovação, como renovação industrial. Um exemplo é a reutilização de resíduos de produtos no uso do processo produtivo, outro é a gestão integrada da água utilizada (DIAS, 2014).

Segundo o Grupo HSBC e Instituto 5 Elementos (2012) e Giannetti e Almeida (2006) se entende como ecoeficiência a procura por alcançar as exigências dos indivíduos e dos serviços (Quadro 3), de modo a minimizar os impactos negativos ao meio ambiente. Na realidade uma organização eco eficiente é aquela que tem a capacidade de com menos material produzir mais.

Quadro 3 - Os três objetivos para a ecoeficiência no mundo estabelecida pelo WBCSD.

\begin{tabular}{|l|l|}
\hline \multicolumn{1}{|c|}{ OBJETIVO } & \multicolumn{1}{c|}{ DESCRIÇÃo } \\
\hline $\begin{array}{l}\text { Redução do consumo de } \\
\text { resíduos }\end{array}$ & $\begin{array}{l}\text { Trata da diminuição com relação a uso de energia, materiais, água } \\
\text { e solo, onde é possível a reciclagem ser favorecida, e o ciclo de } \\
\text { vida estendido, além da minimização do desperdício. }\end{array}$ \\
\hline $\begin{array}{l}\text { Redução do impacto na } \\
\text { natureza }\end{array}$ & $\begin{array}{l}\text { Está ligada a diminuição das emissões atmosféricas, geração de } \\
\text { efluentes, resíduos e ruídos, bem como estimular o uso sustentável } \\
\text { de recursos renováveis. }\end{array}$ \\
\hline
\end{tabular}


Quadro 3 - Os três objetivos para a ecoeficiência no mundo estabelecida pelo WBCSD.

\begin{tabular}{|l|l|}
\hline \multicolumn{1}{|c|}{ OBJETIVO } & \multicolumn{1}{c|}{ DESCRIÇÃO } \\
\hline $\begin{array}{l}\text { Aumento da produtividade } \\
\text { ou do valor do produto }\end{array}$ & $\begin{array}{l}\text { Tem por objetivo oferecer maiores vantagens aos } \\
\text { consumidores, bem como em seus produtos proporcionando } \\
\text { uma maior flexibilidade, funcionalidade, durabilidade e } \\
\text { modularidade de modo que seja possível alcançar o seu } \\
\text { objetivo e ao mesmo tempo usar uma quantidade menor de } \\
\text { recursos desejado. }\end{array}$ \\
\hline
\end{tabular}

Fonte: adaptado de Grupo HSBC e Instituto 5 Elementos (2012) e Giannetti e Almeida (2006).

Para Giannetti e Almeida (2006) e Dias (2014), procurar diminuir a intensidade do material, reduzir a quantidade de energia utilizada em bens e serviços, minimizar dispersão de materiais tóxicos, procurar melhoria na capacidade de reciclagem, otimização no uso de materiais renováveis, prolongar a durabilidade dos produtos, aumentar a quantidade tanto de bens, quanto de serviços, são os sete elementos para a melhoria da ecoeficiência, segundo Conselho Empresarial Para o Desenvolvimento Sustentável (WBCSD).

Giannetti e Almeida (2006) acrescentam ainda que a United Nations Envirommental Programe (UNEP) não distingue a ecoeficiência de Produção mais Limpa. Os mesmos contemplam ainda que os dois conceitos estão ligados quanto à geração de benefícios para a empresa e para o meio ambiente, porém para o alcance dos objetivos elas se diferenciam na abordagem. Sendo o foco da ecoeficiência o impulso da eficiência nas reservas da natureza para se produzir bens e serviços, existindo uma ligação entre performance ambiental e performance financeira, como objetivo principal de usar de forma eficiente as reservas. No entanto, para a Produção mais Limpa o intuito está centrado em uma maior eficiência no uso de processos, serviços, materiais e energia. Deste modo, se reduz o consumo de reservas naturais, assim como são diminuídas a poluição e quantidade de resíduos, e consequentes benefícios, tanto econômicos como ambientais.

Segundo o Grupo HSBC e Instituto 5 Elementos (2012), o lixo não se extingue de uma forma simples no meio ambiente, mas é gerador de tipos distintos de ameaça como: a destruição do meio ambiente, esgotamento de aterros sanitários, rios e córregos contaminados. No Brasil aproximadamente $60 \%$ do lixo coletado é enviado para lixões a céu aberto, sem algum tratamento.

De acordo ainda com o Grupo HSBC e Instituto 5 Elementos (2012) a problemática está relacionada com consumo exagerado e produção de resíduos descontrolada que 
tal consumo acarreta. O Brasil dispõe da Política Nacional de Resíduo Sólidos que determina a alteração da visão do "lixo" para uma visão de resíduo com valor econômico. Várias soluções integradas são buscadas, pois para esta problemática não existe uma única e melhor solução. Redução do consumo é tão relevante quanto pleitear iniciativas de reciclagem. Assim se faz importante pensar nos 5rs:

1) Hábitos e atitudes devem ser repensados.

2) Redução quanto à geração e descarte.

3) Reutilizar aumentando a vida útil do produto.

4) Recusar produtos que sejam agressivos a saúde e o ambiente.

5) Reciclar e transformar o rejeito em um produto novo.

Todos os R's partem do princípio de correlação do gerenciamento de resíduos sólidos, estes vêm sendo dominados pelo desenvolvimento sustentável como: repensar, readequar, reavaliar, reusar, restaurar, reformar. Entretanto os objetivos dos mais relevantes são: reduzir quando se pensa em uma redução de consumo de matériasprimas e energia assim diminuindo também o descarte e reservando os recursos. Reutilizar: usar o produto de novo oferecendo a este ou não uma nova função. Reciclar: devolver o que foi usado ao ciclo produtivo. Assim tais princípios advêm de uma herança hierárquica onde se orienta em direção a uma alteração sustentável tanto de padrões de consumo como de produção Berlim (2012).

\subsection{IMPACTOS AMBIENTAIS E CONSUMO SUSTENTÁVEIS}

Práticas e tecnologias devem ser modificadas por meio do comércio e da indústria, pois ultimamente o cuidado referente a questões ambientais tem se tornado o foco da política, economia e sociedade. Isso acontece pelo fato de todos estarem cada vez mais conscientes em relação às atividades de negócios e aos impactos que as mesmas podem transferir ao ambiente, fazendo as instituições desenvolverem formas de benefício ao meio ambiente em suas produções (EPA, 2011).

Para Barbieri (2007) pode-se entender impacto ambiental por alguma alteração no ambiente natural ou social que advém de uma ação ou de um empreendimento oferecido, tendo como foco todas as alterações causadas pelo ser humano. É possível haver impactos positivos, que se verificam como atividades sociais, ambientais e 
sustentáveis economicamente ou negativos que são efeitos de degradação e que são conclusões indesejadas das atividades humanas.

Segundo Manzini e Vezzoli (2011), cada ação do homem estabelece uma absorção/aquisição de recursos do meio ambiente, as quais acontecem como liberações de alguns tipos de emissões, tais como substâncias e ruídos. São formas de impacto no meio ambiente sejam extrações como a utilização de matérias-primas ou emissões que se entende pela liberação de substâncias. Portanto, entre o sistema de produção, consumo e o ambiente há uma troca de substâncias na sua origem que é individual de cada forma de impacto.

É exercida pela humanidade uma pressão sobre os recursos naturais ocasionando um rompimento no equilíbrio ecológico que são chamados de impactos ambientais. Estes, por sua vez, tiveram um crescimento nos últimos anos e se tornaram diversos por conta de inúmeros fatores introduzidos na sociedade, ademais, danos ambientais são causados devido ao crescimento populacional e o desenvolvimento das cidades (ANTONI; FOFONKA, 2013).

Para Manzini e Vezzoli (2011), uma das formas de se minimizar os impactos ambientais é reduzindo a utilização das matérias-primas, pois desta maneira é possível evitar a transformação, o transporte e o descarte do mesmo e consequentemente economiza-se energia na produção. Compreende-se a minimização de recursos como sendo a diminuição dos consumos de matérias-primas e energia para um devido produto e um deliberado serviço proporcionado pelo produto. Durante todo o ciclo de vida do produto, os materiais e energia são empregados em distintas proporções. Assim todas as etapas das atividades do projeto e da gestão do produto devem objetivar a diminuição dos consumos de recursos.

Realizar um equilíbrio entre o que se produz e o que se descarta é cada vez mais difícil, e com isso é crescente o descarte de maneiras erradas. Os excessos residuais são descartados em rios, córregos, ruas e terrenos baldios. Por isso o aumento com preocupações em relação aos impactos que, tanto produtos como processos industriais causam ao meio ambiente, e com a busca de soluções para equilibrar estas instabilidades, procurando-se encaminhar de melhor maneira a estruturação e organização de canais de distribuição reversa (LEITE, 2009). 
Ainda Leite (2009) afirma que há dois tipos de disposição final dos excessos residuais. A disposição final segura é aquela em que os bens que são despachados fazem uso de um caminho controlado, que de alguma maneira não cause danos ao meio ambiente e que não afete a sociedade, seja de modo direto ou indireto. Em contrapartida denomina-se disposição não segura aquela em que os bens são despachados de maneira não controlada e em quantidade indevida em rios, mares, lixões e terrenos baldios.

Manzini e Vezzoli (2011) acrescentam que as extrações dos recursos e as emissões são responsáveis pelos impactos, e além disto o nosso ecossistema não absorve tais ações. Desta maneira compromissando o equilíbrio da sobrevivência do ser humano, assim como da flora e da fauna.

Segundo Barbieri (2007), o Estudo de Impacto Ambiental (EIA) é o instrumento de gestão ambiental cabível a planos de atividades e projetos, para apontar e qualificar antecipadamente os impactos e como solucioná-los antes de implantar o que se deseja. Segundo Sanches (2011), trata-se da resolução CONAMA no 001/1986 que dispõe de indicações básicas e das diretrizes gerais onde se torna possível realizar um estudo de impacto ambiental e também ao Relatório de Impacto Ambiental (RIMA), ambos os procedimentos da Avaliação dos Impactos Ambientais (AIA) que se trata de uma das elementares formas de avaliação do desempenho ambiental. Para Sanches (2011), nosso país possui um complexo conjunto convencional de gestão do meio ambiente, que é administrado por uma diversidade do sistema jurídico. A atual legislação foi concretizada em momentos distintos em diferentes contextos sociais, políticos e econômicos.

Giannetti e Almeida (2006) afirmam que a avaliação do impacto ambiental deve definir a gravidade dos impactos e desta forma separá-la em três etapas que são: classificação, caracterização e valoração (Figura 4).

Com relação às etapas tem-se que na classificação é importante separar os impactos com base no espaço receptor ou de acordo com os efeitos ao meio ambiente. A caracterização está associada às substâncias e a medida e efeito de cada uma, por fim a valoração é a etapa onde deve-se interpretar todos os dados obtidos e verificar como pode-se melhorar o projeto em estudo (GIANNETTI; ALMEIDA, 2006). 
Figura 4- Etapas para avaliação de impacto

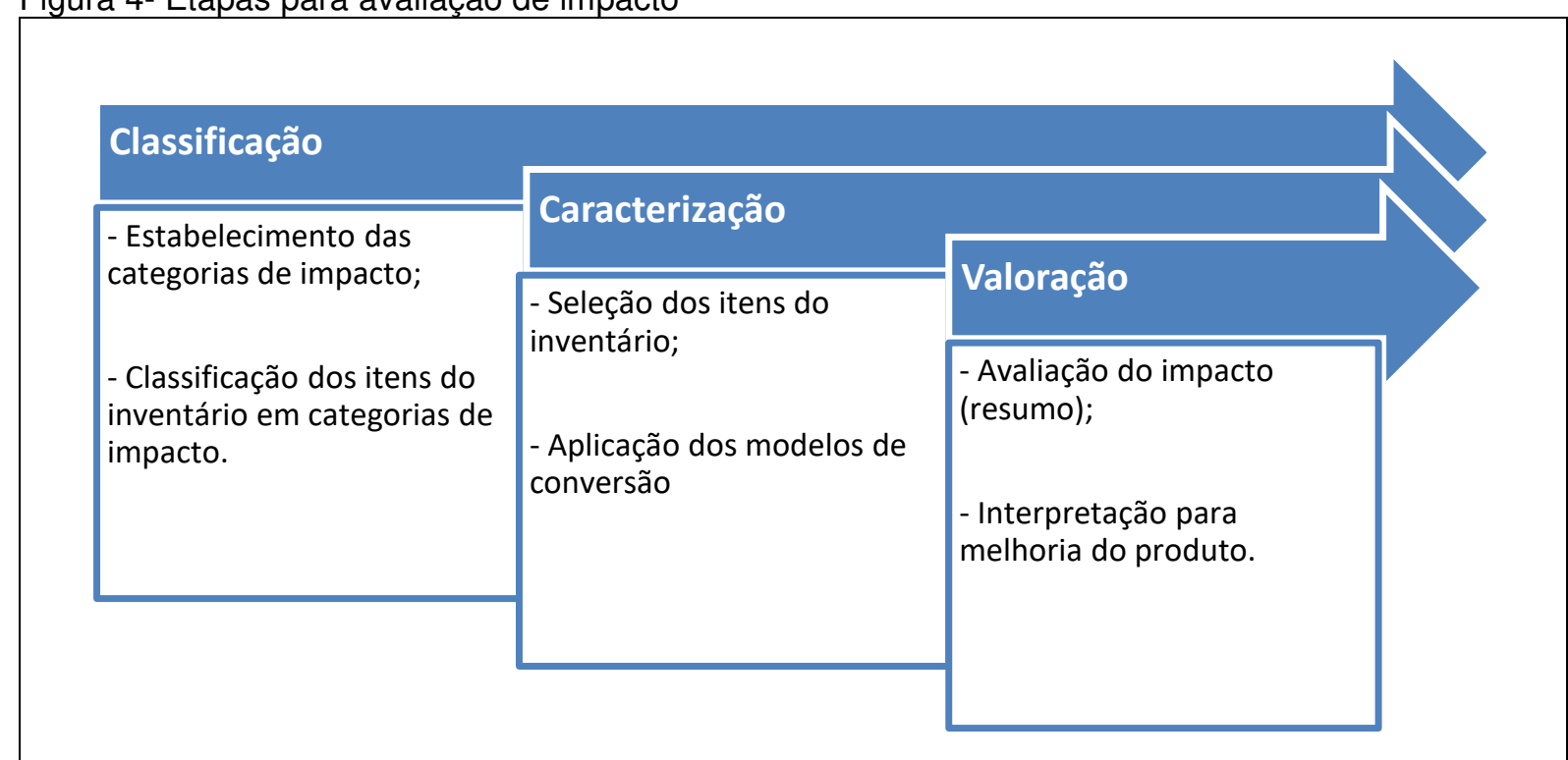

Fonte: adaptado de Giannetti e Almeida (2006).

Para Manzini e Vezzoli (2011), as circunstâncias em que um produto é manufaturado, utilizado e descartado interferem no peso que o mesmo tem com relação aos impactos ambientais, pois se um produto tem uma maior durabilidade, mesmo que para tanto tenha sido necessário um impacto em sua fabricação, isso se equilibra com a sua durabilidade, já que levará muito mais tempo para ser descartado. Barbieri (2007) completa ainda que a criação de instrumentos para a prevenção de impactos ambientais se dá também na fase do planejamento do projeto, de forma a evitar danos ao ambiente físico, biótico e social, de maneira a proporcionar melhorias no projeto.

Segundo Manzini e Vezzoli (2011), a LCA até o momento é considerada o método de análise de impacto ambiental mais seguro e confiável. É crescente o interesse por este instrumento, mas ainda há relevantes questões a serem determinadas, especialmente quando se pensa em usá-lo auxiliando projetos. Os autores ainda contemplam que o impacto ambiental de um produto pode ser melhorado, com mais possibilidades, na primeira fase de desenvolvimento, devido às propostas de inovações que surgem nesta etapa.

Manzini e Vezzoli (2011), afirmam ainda que atualmente a LCA é usada nas primeiras fases do projeto, de maneira geral, somente para avaliar produtos que já existem. Pode-se realizar na prática individualizando as fases e os processos de grande impacto e, deste modo traçar uma sequência de preferências ambientais quanto aos produtos, assim se tornando relevante o conhecimento em prioridades ambientais para direcionar escolhas. 
Para Barbosa Filho (2009), os princípios e objetivos quanto às orientações gerais no desenvolvimento de produtos conduzindo as questões ambientais podem ser destacados como:

a) Preservar energia e recursos naturais: deve-se assegurar que a disposição de recursos naturais não seja prejudicada pelos produtos. Assim se faz necessário que o consumo não seja maior do que a natureza possa nos ofertar. Por este motivo, deve-se reduzir o consumo das matérias-primas e energia, pensando desde o início da concepção do produto até a embalagem, transporte, uso e eliminação do mesmo.

b) Minimizar emissões e produtos poluidores: a quantidade de resíduos e substâncias poluidoras jogadas na terra não pode ser maior daquela que a natureza tenha a capacidade de absorver. Os produtos não devem ser feitos com elementos nocivos.

c) Política social e ambiental da empresa: a empresa deve assegurar as condições de trabalho, sem causar lesões tanto fisicamente quanto psicologicamente, e as atividades devem ser benéficas socialmente e ao mesmo tempo justas ecologicamente.

d) Reciclagem e ciclo de vida: na fabricação dos produtos deve-se pensar na possibilidade do reuso dos materiais, após o seu descarte podendo ser inseridos na cadeia de produção, ou possuírem caráter biodegradável.

e) Facilidade de concerto e ação tecnológica: o produto deve apresentar qualidade, e concerto de modo fácil assim evitando sua substituição por outro, ou ainda permitir uma atualização, evitando-se a troca por outro mais moderno.

f) Estética e vida longa: os produtos devem possuir na sua construção uma estética aprazível e sólida de modo a assegurar ao longo do tempo sua durabilidade e permanência.

g) Multiuso: deve-se incentivar que um mesmo produto possa ser desfrutado por inúmeros usuários e que produtos sejam projetados com a intenção de realizarem mais de uma função. 
Barbosa Filho (2009) ainda acrescenta que a procura pela sustentabilidade, por sua vez, é de garantir às gerações do futuro o direito a um meio ambiente equilibrado, com as mesmas condições quanto a natureza, a sociedade e a economia que estão disponíveis para as gerações atuais. Acarretou a discussão sobre o projeto do produto, evidenciando-se aqueles que permeiam recursos naturais não renováveis. Abordagens como minimização no uso, reutilização e reciclagem ganharam lugar decisivo no projeto, bem como aproveitamento de fontes alternativas de energia e a ideia de uma produção sem excessos.

A produção sustentável tem como intuito o desenvolvimento de estratégias que cooperam para um aumento da produtividade e para a eficiência dos recursos em diversos processos que acontecem no ciclo de vida do produto. Ambientalmente a intensão é a ecoeficiência, cujo propósito está no cerne do desenvolvimento de procedimentos produtivos que reduzam o impacto ambiental negativo por meio da diminuição do uso de recursos de matéria-prima e energia, e pela geração mínima de resíduos, sejam eles em estados sólido, gasoso ou líquido no decorrer do ciclo de vida do produto (DIAS, 2014).

A Produção e Consumo Sustentável (PCS) para Dias (2014) estão conceituados na incorporação da análise do ciclo de vida de um produto. Assim sendo, ao se tratar de uma produção, diversos processos estão embutidos, a começar pela extração da matéria-prima até a restituição ao sistema produtivo dos resíduos sólidos. Assim, quando se fala em consumir não se deve pensar apenas na etapa de adquirir um bem ou serviço, mas também deve-se considerar o procedimento precedente e o posterior como o uso e o descarte do produto.

Segundo a NBR ISO 14040:2001 (ABNT, 2001), devido ao aumento da conscientização com relação às questões ambientais é cada vez mais crescente o interesse em aumentar métodos que contribuam com minimização destes impactos, sendo um destes métodos a Avaliação do Ciclo de Vida (ACV).

A sequência de fases do desenvolvimento do produto (Erro! Autoreferência de indicador não válida.) desde a obtenção das matérias primas e insumos, seu processo produtivo, o consumo e até a disposição final são denominados ciclo de vida do produto (BRASIL, 2010). 
Figura 5 - Ciclo de vida do produto.

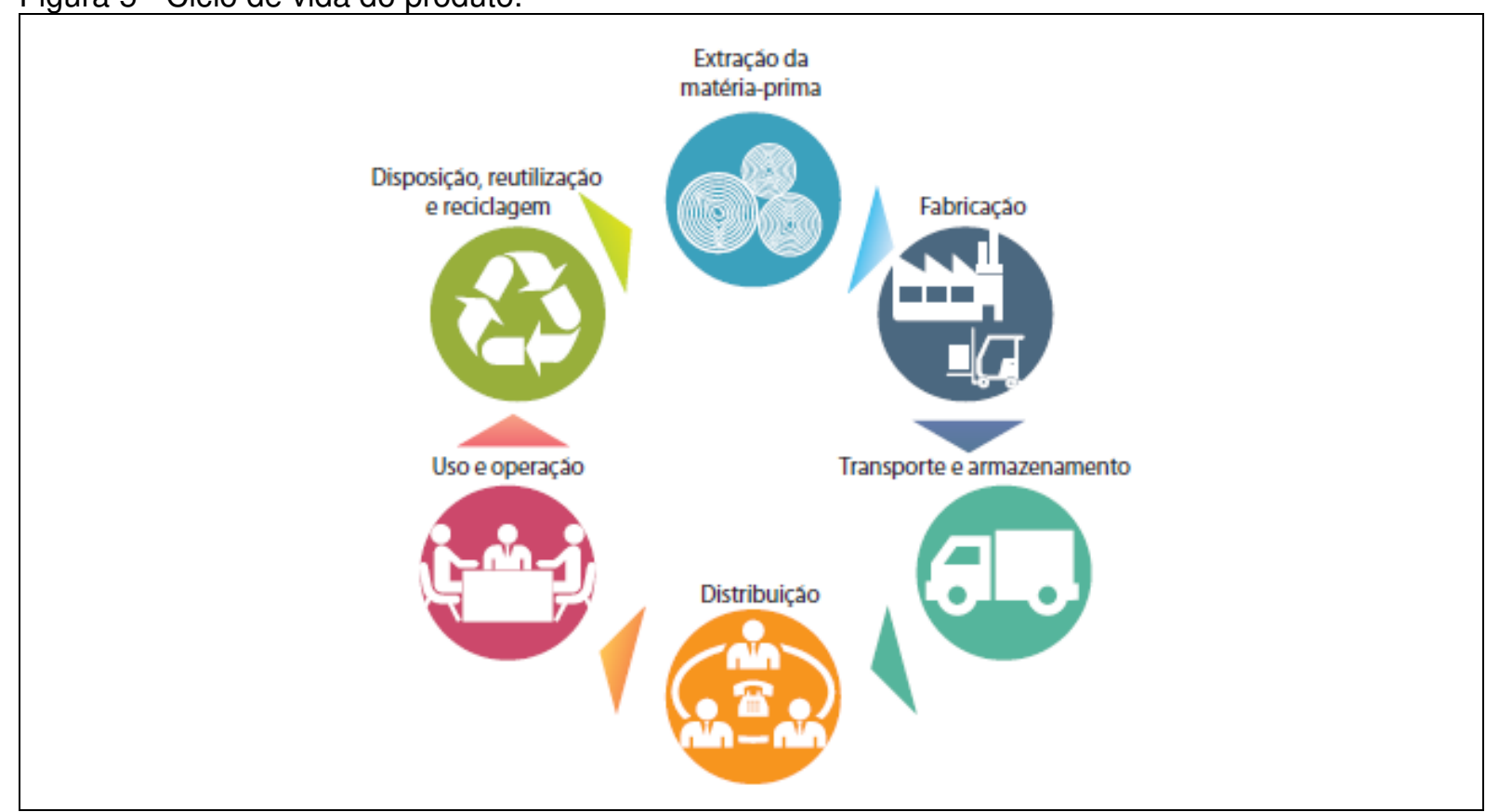

Fonte: Almeida (2014).

Compreende-se como ciclo de vida do produto uma sequência de fases que permeiam todos os processos de seu desenvolvimento, assim como o retorno destes materiais ao início do processo (ALMEIDA, 2014).

Para Barbieri (2007), a ACV é um instrumento de gestão ambiental e pode ser aplicado a bens e serviços em todos os seus estágios, desde o início até o fim do processo. Também é identificada pela expressão do berço ao túmulo (crade to grave), onde se entende como berço à nascente dos insumos primários e túmulo o destino final dos resíduos que não serão reusados ou reciclados.

Apesar de algumas limitações inerentes a ACV, esta é considerada como uma ferramenta exclusiva para identificar impactos e implementar estratégias para diminuição do impacto ambiental de determinados produtos com a finalidade de comparar os méritos relativos de produtos e processos (GIANNETTI; ALMEIDA, 2006). Este modelo fornece um pequeno apoio para definir a necessidade de novas tecnologias e é frequentemente aplicado de modo a analisar a gestão de resíduos sólidos (QU; ZHANG; LIANG, 2012).

Segundo Giannetti e Almeida (2006), o reuso, a reciclagem do produto e a reciclagem do material devem estar associadas ao ciclo de vida do mesmo, como se pode observar na Figura 6. 
Figura 6 - Principais estágios do ciclo de vida de um produto.

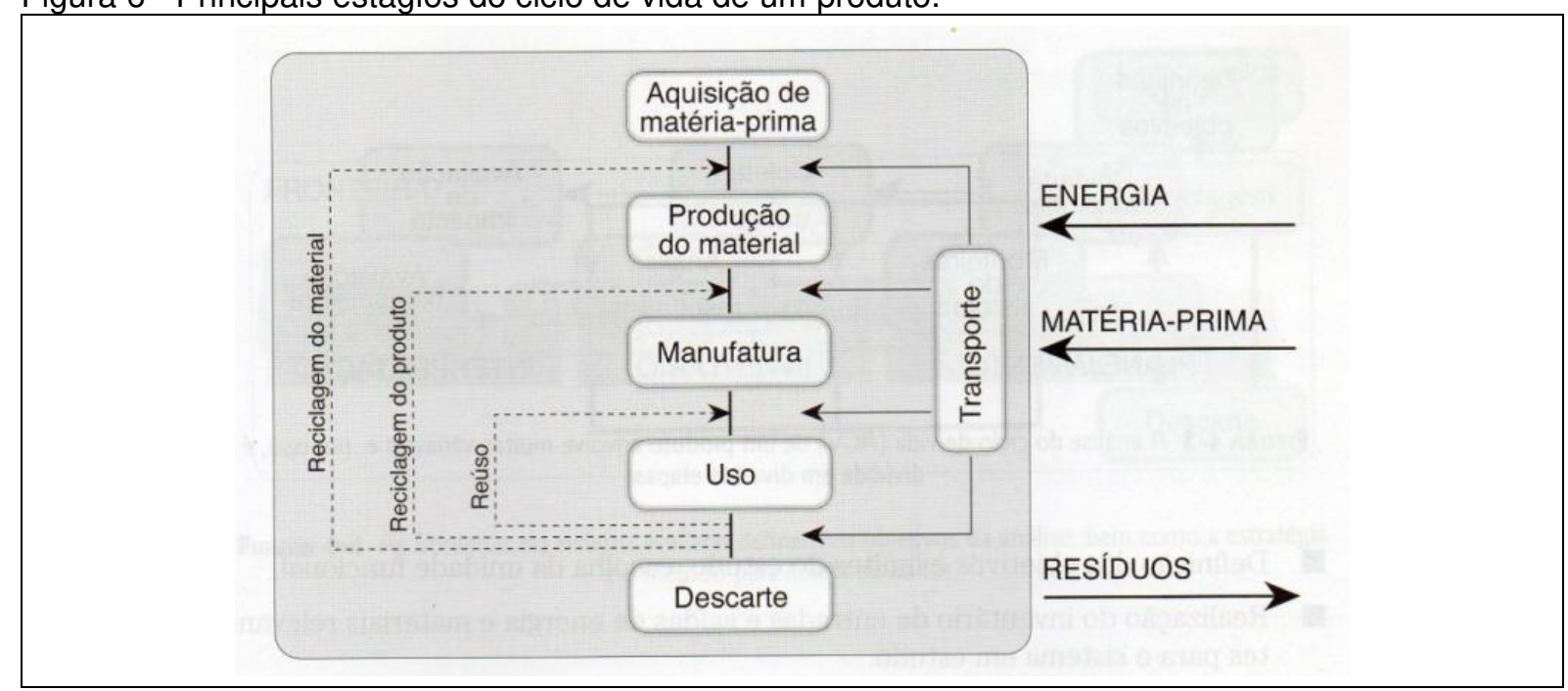

Fonte: Giannetti e Almeida (2006).

\subsection{POLÍTICA NACIONAL DE RESÍDUOS SÓLIDOS (PNRS)}

De 2003 a 2014 o aumento da geração de lixo no Brasil foi de 29\%, o que equivale a cinco vezes a taxa de crescimento populacional, segundo Associação Brasileira de Empresas de Limpeza Pública e Resíduos Especiais (Abrelpe apud MACIEL, 2015). Todavia, o crescimento do lixo gerado não foi acompanhado pela quantidade de resíduos sólidos com destinação correta, sendo que apenas $58,4 \%$ da totalidade dos resíduos no ano de 2014 foram destinados a aterros sanitários. Entre os anos de 2010 a 2014 houve um aumento de 7,2\% no número de municípios que possuem alguma iniciativa de coleta seletiva (MACIEL, 2015).

Segundo a Política Nacional de Resíduos Sólidos é definido resíduo sólido como o:

material, substância, objeto ou bem descartado resultante de atividades humanas em sociedade, a cuja destinação final se procede, se propõe proceder ou se está obrigado a proceder, nos estados sólido ou semissólido, bem como gases contidos em recipientes e líquidos cujas particularidades tornem inviável o seu lançamento na rede pública de esgotos ou em corpos d'água, ou exijam para isso soluções técnica ou economicamente inviáveis, em face da melhor tecnologia disponível (BRASIL, 2010).

A gestão integrada e sustentável de resíduos é fortalecida pelos princípios da PNRS que faz uma proposta de medidas que incentivam a se formar consórcio público de gestão regionalizada. Com uma visão de ampliação da capacidade de gestão das administrações municipais, através de ganhos de escala e diminuição de custo, 
trando-se de compartilhar sistemas de coleta, tratamento e destinação de resíduos sólidos (JACOBI; BESEN, 2011).

Para se classificar resíduos sólidos se faz necessário identificar o processo ou atividade do qual foi originado, a sua constituição e características, comparando estes dados com lista de resíduos e substâncias das quais os impactos a saúde e ao ambiente são denominados. Os resíduos sólidos são divididos em: I) perigosos e II) não perigosos, como pode-se observar na Figura 7.

Figura 7 - Caracterização e classificação de resíduos.

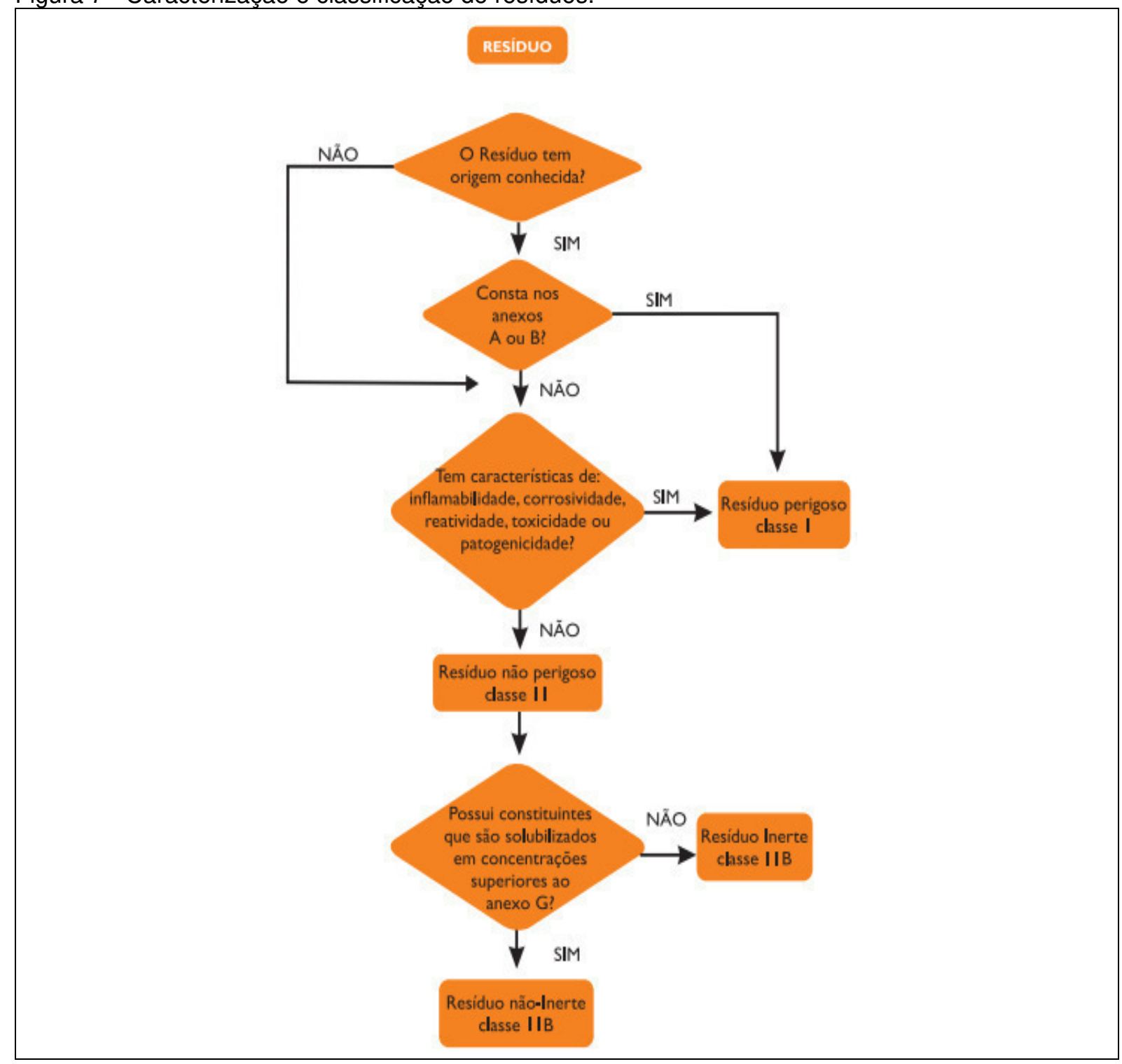

Fonte: Almeida (2014). 
Ainda para Almeida (2014), a classificação dos resíduos perigosos (classe l) se dá em função de suas propriedades, tais como: inflamabilidade, corrosividade etc. Este tipo de resíduo compreende a criação de um planejamento de gerenciamento próprio a ser introduzido no plano de gerenciamento de resíduos sólidos. Quanto aos resíduos não perigosos (classe II), devido a sua natureza, composição ou volume, não se caracterizam como perigosos. Entre eles encontram-se, por exemplo, resíduos recicláveis (papéis, plásticos, metais e vidros).

Segundo Fagundes, Silva e Mello (2015) no artigo 9ำ da Política Nacional dos Resíduos Sólidos (não geração, redução, reutilização, reciclagem, tratamento dos resíduos sólidos e destinação final ambientalmente adequada dos rejeitos) percebese uma aproximação com as estratégias para prevenção a poluição, direcionando de acordo com um conjunto de escolhas de modo a privilegiar de maneira lógica e articulada, conseguida por meio da integração de práticas de Produção mais Limpa e de controle de fim de tubo.

\subsection{SETOR TÊXTIL}

Para Ozturk et al. (2015) a indústria têxtil é um dos setores de maior influência econômica principalmente para países em desenvolvimento. O Brasil se encontra em quarto lugar entre os grandes produtores globais de artigos do vestuário, já em manufatura de têxteis o Brasil vem posicionado em quinto lugar entre os maiores produtores (ABIT, 2013). A indústria do setor têxtil é possuidora de distintas características, que em outros setores se tornam difíceis de serem encontradas. Abrange arte, tecnologia e negócios. No Brasil são encontradas mais de 100 escolas nesta área, sendo que o mesmo ainda fatura aproximadamente $R \$ 100$ bilhões/ ano por meio de mais de 30 mil empresas. Foi o país que mais cresceu na última década e encontra-se entre os oito maiores mercados consumidores globais do vestuário, cama, mesa e banho (ABIT, 2014).

O setor têxtil e de confecção possui uma estrutura muito vasta e complexa que reflete a potência socioeconômica da história da indústria nacional. Devido ao processo de globalização em todos os setores, está havendo um crescimento em relação à competitividade nas empresas têxteis e de confecção brasileiras (BONDUKl; 
PIMENTEL, 2012). O setor brasileiro se destacou como o segundo maior empregador de mão de obra da indústria de transformação no ano de 2012, devido a possuir um grande número de empresas e de mão de obra, sendo relevante no segmento da confecção e vestuário (MENDES, 2010).

Segundo Abit (2015), o Brasil emprega de forma direta 1,7 milhões de pessoas, sendo $75 \%$ do gênero feminino. Na indústria de transformação, a indústria da moda se encontra como o segundo maior empregador, assim como o segundo maior gerador de primeiro emprego. Um setor imenso, com relevância tanto social como econômica.

Segundo a Abit (2013), no Brasil são produzidas desde as fibras até as confecções, sendo considerado um país que dispõe de uma das últimas cadeias têxteis completa do ocidente. Constatam-se mais de 32 mil empresas agrupadas neste setor, sendo mais de $80 \%$ de confecções de pequeno e médio porte, encontradas em todo território nacional. Por sua vez, este setor retrata aproximadamente $6 \%$ do valor absoluto da produção da indústria de transformação. A geração de empregos da cadeia têxtil equivaleu a $15,2 \%$ da totalidade de trabalhadores na produção industrial no ano de 2012, destacando-se pela sua importância econômica, sendo um forte representativo de impacto social (IEMI, 2013).

Quanto à distribuição da indústria têxtil no Brasil com relação à Receita Operacional Líquida (ROL) de vendas equivale a $R \$ 40,6$ bilhões em 2011, dos quais o Norte participa com uma parte mínima de $0,4 \%$, em sequência tem-se o Centro-Oeste com $3,5 \%$, ambos possuindo pouca representação nesta atividade industrial. Todavia o nordeste possui $15,6 \%$ e, como os principais produtores, há o Sul com $28,3 \%$ e o Sudeste com $52,2 \%$. O Gráfico 3 mostra a participação por estado de cada uma das regiões relevantes. 
Gráfico 3 - Participação dos estados no ROL da indústria têxtil do Brasil.

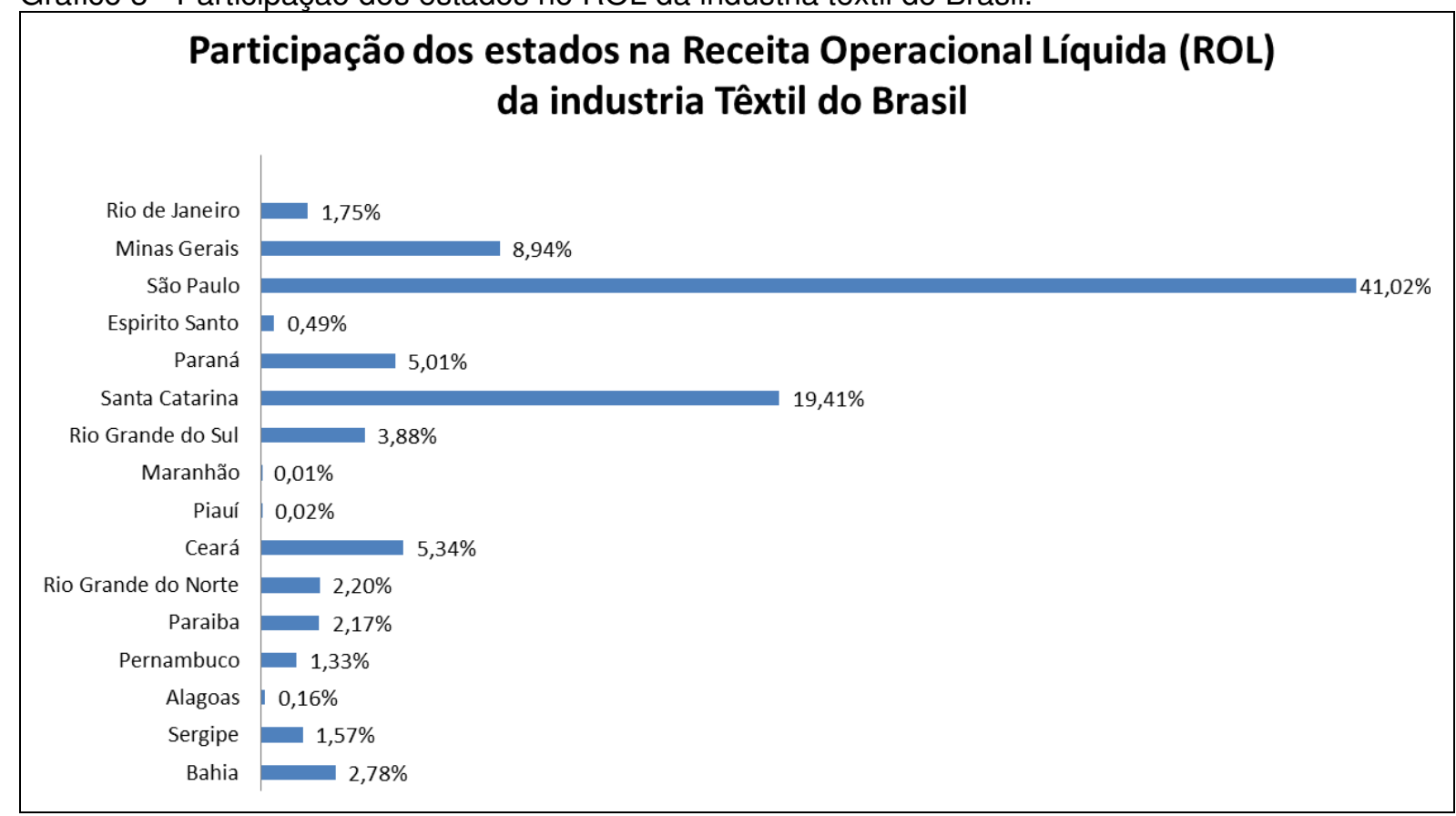

Fonte: adaptado de Bezzera (2014).

No Comércio internacional, em 2012 o Brasil possuía uma participação reduzida ocupando a $21^{\text {a }}$ colocação entre os grandes exportadores de têxteis e $80^{\text {a }}$ entre os maiores exportadores de vestuário. Desta forma, pode-se verificar que o país está associado ao perfil de "produtor consumidor" (que produz para si mesmo). Tem-se a China como principal exportador de têxteis e vestuários possuindo $33,2 \%$ do mercado exportador. $O$ posicionamento do Brasil com relação às importações não se difere muito da sua exportação assim sendo o $19^{\circ} \mathrm{em}$ têxteis e $30^{\circ} \mathrm{em}$ vestuário. Como principal importador tem-se neste ano os Estados Unidos com 15,5\% dos valores registrados pelo ITC (Internacional Trade Center) (IEMI, 2013).

A indústria do têxtil e do vestuário esteve voltada nos últimos tempos aos aspectos de custo do produto e suas tecnologias. O destaque tem sido posto em se manter o preço do produto final barato e um crescimento na eficácia da produção. As tendências ditam as mudanças e designers, fabricantes e varejistas têm dado mais atenção a modelos de negócios com relação a valores e desejos. Assim produtos são fabricados com rápidas multiplicações ao invés de se pensar de forma radical no produto voltado para o consumidor e a sustentabilidade (NIINIMÄKI; HASSI, 2011).

Ainda Niinimäki e Hassi (2011) afirmam que o sistema atual da indústria têxtil e do vestuário tem base em ciclos de vida rápidos, indicados pelas tendências de moda que produzem de forma contínua necessidades novas e produtos de consumo. Os 
ciclos de vida do produto são reduzidos, e por sua vez as corporações querem abastecer seus produtos rapidamente.

O faturamento no Brasil com relação ao setor de moda é de mais de US\$21 bilhões por ano. O país assume mundialmente a segunda posição entre os fornecedores de índigo, no segmento de malhas encontra-se como fornecedor em terceiro lugar, na confecção está em quinta posição, e na distribuição de fios, filamentos e tecidos, ocupa a oitava posição. Possuindo assim, mundialmente, um dos maiores parques fabris (SEBRAE, 2014).

Nos últimos anos (2008-2012) houve um aumento de 43,2\% na produção de têxteis no Brasil enquanto que o comércio internacional de têxteis e vestuário teve um acréscimo de $2,1 \%$. No segmento brasileiro de malhas, tem-se uma produção de tecido com média de 615.352. (ton.) entre os anos de 2008 a 2012 (IEMI, 2013). Para Machado Junior e Torquetti (2014) realizar estudos para cálculo ou indicação com relação a diagnósticos do processo produtivo têxtil é muito relevante, pois baseado na análise e mapeamento dos processos é possível apontar as entradas e saídas de cada processo, destacando os principais impactos gerados.

A indústria têxtil e de confecção brasileira está presente em todo o território nacional proporcionando desenvolvimento e emprego, sendo muito mais ampla, pois vai além do vestuário (fundamental bem final deste setor) como pode ser observado na Figura 8.

Figura 8 - Relevância econômica do setor têxtil.

Parque

Industrial de

$30 \mathrm{mil}$

8 milhões de empregos

diretos e empresas em indiretos

Faturamento

$4,9 \%$ da Ind. atividade

$\mathrm{R} \$ 80$ Bilhões

em ativos

Fonte: adaptado de Bonduki e Pimentel (2012).

Diversas etapas se unem para atingir um processo sequencial, assim a produção na indústria têxtil é resultado de várias combinações e inúmeras etapas do processo 
produtivo, formando um panorama difícil o qual é dependente de matérias-primas, maquinários e equipamentos específicos (RANGEL; SILVA; COSTA, 2010).

\subsubsection{Manufatura do vestuário de moda (MVM)}

Bezzera (2014) contempla que a cadeia produtiva e sua estrutura de distribuição têxtil e de confecção abrange desde a produção de fibras têxteis até mesmo o produto finalizado e feito, englobando sua distribuição e comercialização. Mendes (2010) relata que a indústria têxtil é uma ampla colaboradora da economia, gerando empregos em seus inúmeros segmentos, e também se destaca por possuir em seus produtos finais uma diversidade de materiais e insumos, sendo considerada uma indústria impulsionadora e que contribui para manter ou desenvolver a força da economia dos países em geral.

Mendes (2010) defende que a cadeia têxtil (Figura 9) abraça produtos de moda ou inclinando-se a commodities, compondo uma rede diversificada de setores industriais nos quais apresentam estruturas diferidas em questões de espaço e quantidade de corporações, mão de obra intensa, dinheiro e tecnologias complexas. Acrescenta ainda que a moda traz um movimento que se prolonga com mudanças frequentes, $\mathrm{e}$ se move de forma a resgatar as cores, assim como as formas e texturas, que acontecem de época em época, contudo com visuais inovadores, aplicações de processos modernos, de novos materiais e tecnologias.

Uma característica importante deste setor segundo Bezzera (2014), é a sua presente verticalização em alto grau, principalmente nos elos: fiação mais tecelagem, fiação mais malharia, e malharia mais confecção. Em que há também um número reduzido de corporações que detêm os elos todos da cadeia têxtil e que estão introduzidos verticalmente. 
Figura 9 - Cadeia Têxtil Completa e sua rede de negócios.

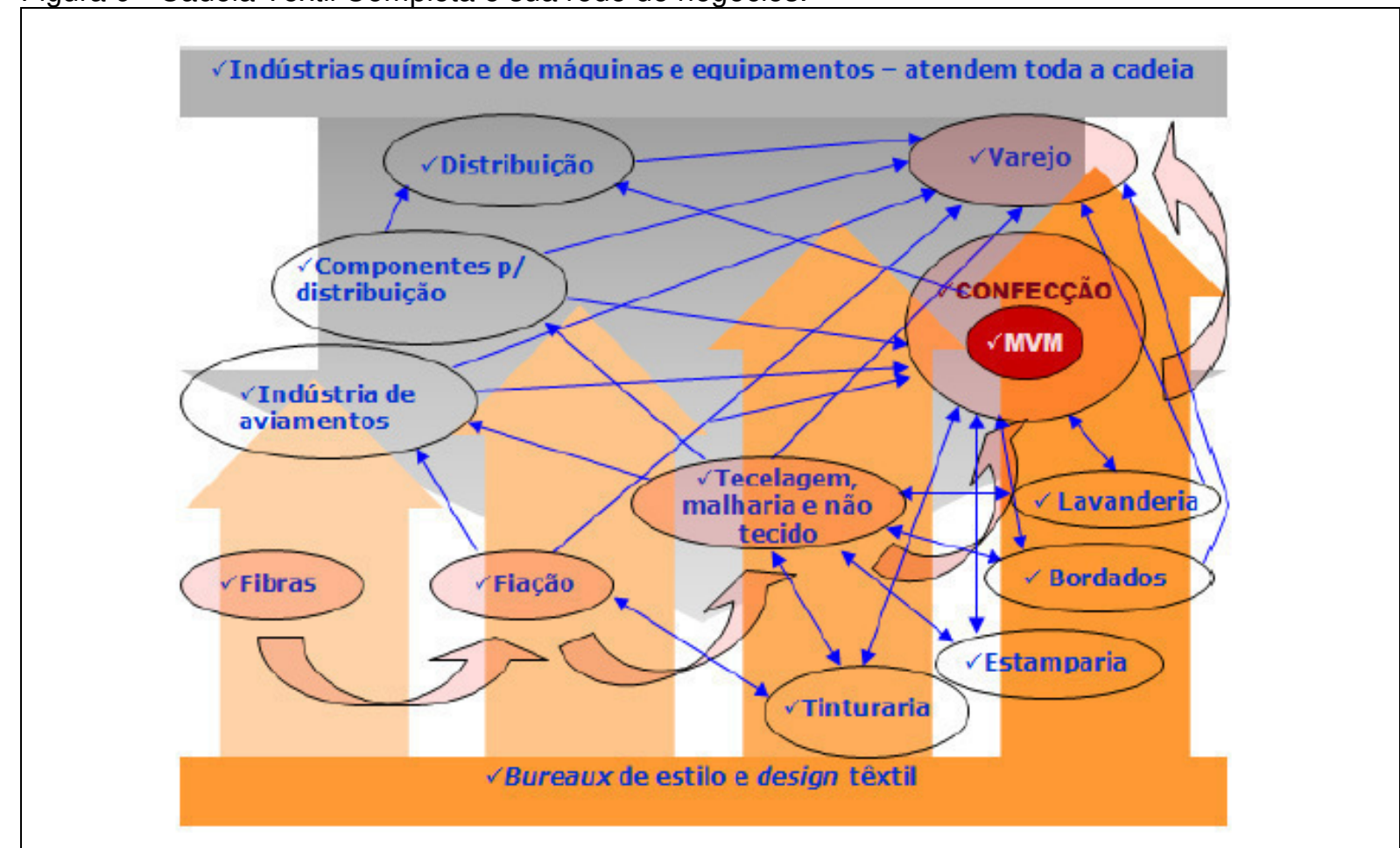

Fonte: Mendes (2010).

Segundo Bastian e Rocco (2009), a cadeia têxtil é responsável por diversas fases do processo produtivo onde se destacam: a fiação (etapa de obtenção de fios por meio de fibras têxteis), beneficiamento (fase preparatória dos fios para uso final), enobrecimento (envolve preparação, tingimento, estamparia e acabamento), tecelagens ou malharia (etapa de fabricação dos tecidos, plano ou malha a partir de fios têxteis), e confecção (fabricação dos produtos têxteis envolvendo tecnologias), além de outras atividades relacionadas direta ou indiretamente.

Manufatura do vestuário de moda (MVM) refere-se ao mesmo segmento da indústria do vestuário, no entanto, ressalta os próprios procedimentos e processos da confecção e produção. Logo, a MVM trata de uma expressão que considera o método e a produção para se alcançar um produto final (MENDES, 2010).

A indústria do vestuário é entendida por Mendes (2006) desde produtos fabricados em grande escala ou com ampla distribuição, podendo ser considerados commodities, ou tendendo a, assim como produtos de moda que possuem: quantidade reduzida por modelo, ciclo de vida curto, extensa variação e diferenciação. 


\subsection{SETOR DE MALHARIA RETILÍNEA}

Segundo Maluf e Kolbe (2003), tecidos de malhas se classificam em duas formas: malharia por trama e malharia por urdume, no qual cada uma delas ainda apresentam outras divisões devido ao caráter do maquinário utilizado, bem como mercadoria produzida. Para Pezzolo (2007), a malharia por trama responsável pela fabricação de tecidos abertos, também chamados de malha retilínea ou circular, resulta em um tubular que se divide em diferentes diâmetros de máquinas conforme 0 artigo desejado. Já a malharia por urdume caracteriza-se pela fabricação de malhas em que os fios são entrelaçados no sentido do comprimento, resultando em um tecido mais firme e indesmalhável.

Na Figura 10 encontra-se a classificação e divisão dos tecidos de malha produzidos na malharia. A circular apresenta um formato de tubo (UDALE, 2009). Este tipo de maquinário é considerado mais produtivo e com bom rendimento possibilitando os mais diferentes tipos de tecidos, como malhas duplas, meias, cadarços, galões e outros, conforme o diâmetro empregado (MACHADO JUNIOR; TORQUETTI, 2014). Já a malharia por urdume se difere quanto ao seu maquinário onde as malhas da Kettenstuhl são responsáveis pelo uso de fios finos e tecidos lisos e a Raschel por sua vez produz malhas texturizadas como, por exemplo, rendas (UDALE, 2009).

Figura 10 - Divisões da Malharia e maquinários.

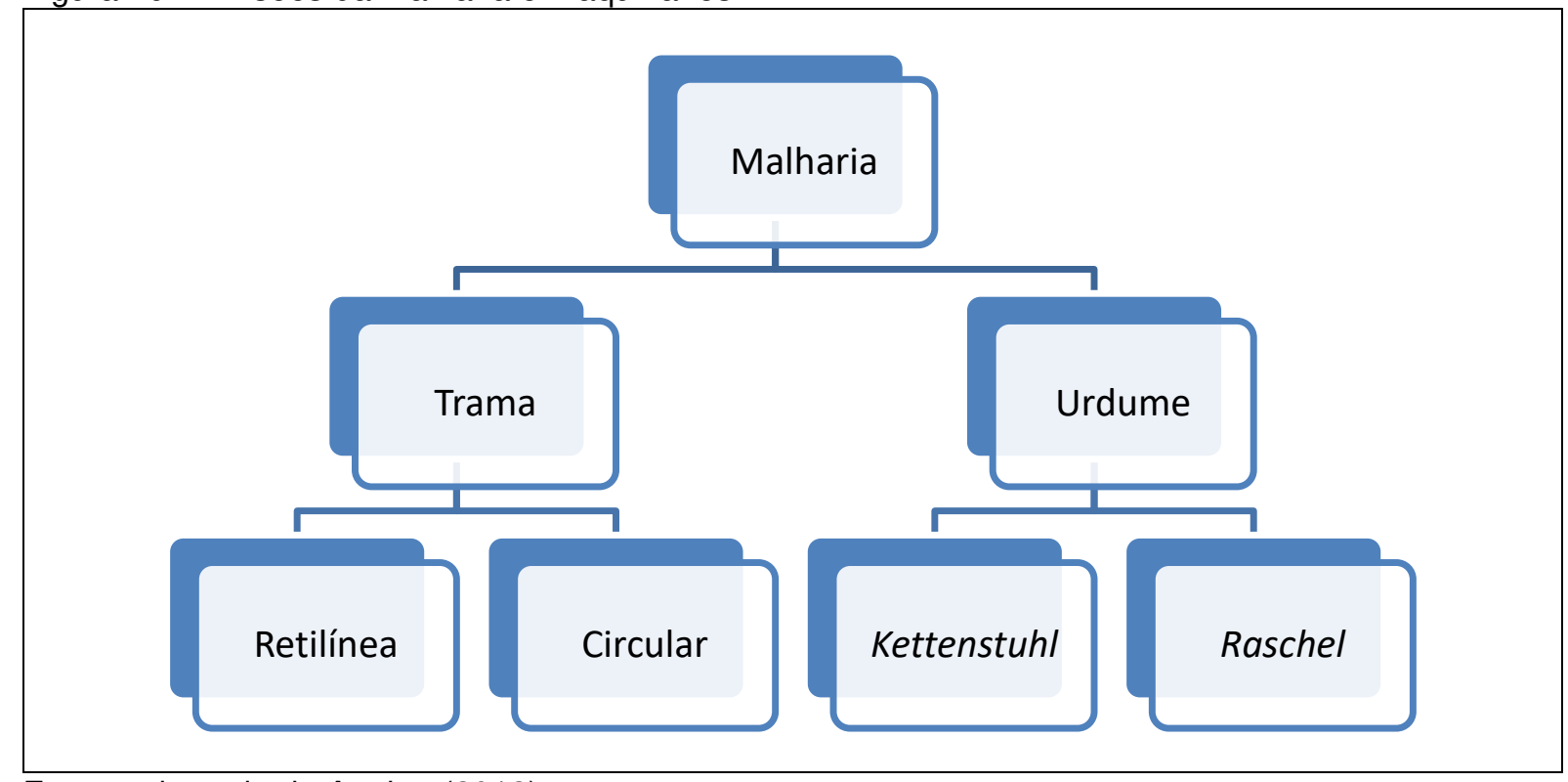

Fonte: adaptado de Aquino (2012). 


\subsubsection{Manufatura do Vestuário de Moda em Malharia Retilínea (MVMMR)}

Segundo Mendes, Sacomano e Fusco (2010), a cadeia têxtil deve ser apresentada por um relacionamento de empresas por meio de uma rede formada de maneira complexa que deve perpassar desde os fornecedores de matéria-prima até os distribuidores do produto final. Podemos observar que a Malharia Retilínea (MR) está inserida a esta cadeia de forma singular (Figura 11), pois a mesma está entrelaçada a todos os elos desta cadeia. Roos (2001) vem complementar dizendo que o setor industrial de malharia retilínea, por sua vez, se encontra inserido na cadeia têxtil bem como na indústria têxtil brasileira, mostrando seus elos de processos nos quais um está interligado ao outro.

Sissons (2012), Pezzolo (2007) e Udale (2009) asseveram o conceito de malharia por trama no qual um único fio é responsável pela construção das laçadas e estas por sua vez se formam no sentido do comprimento do tecido (fileira) e no sentido largura do mesmo (carreira). Assim a malha é tricotada ao longo da urdidura e da trama, oferendo uma qualidade elástica ao mesmo.

Figura 11 - Cadeia têxtil completa e sua rede de negócios.

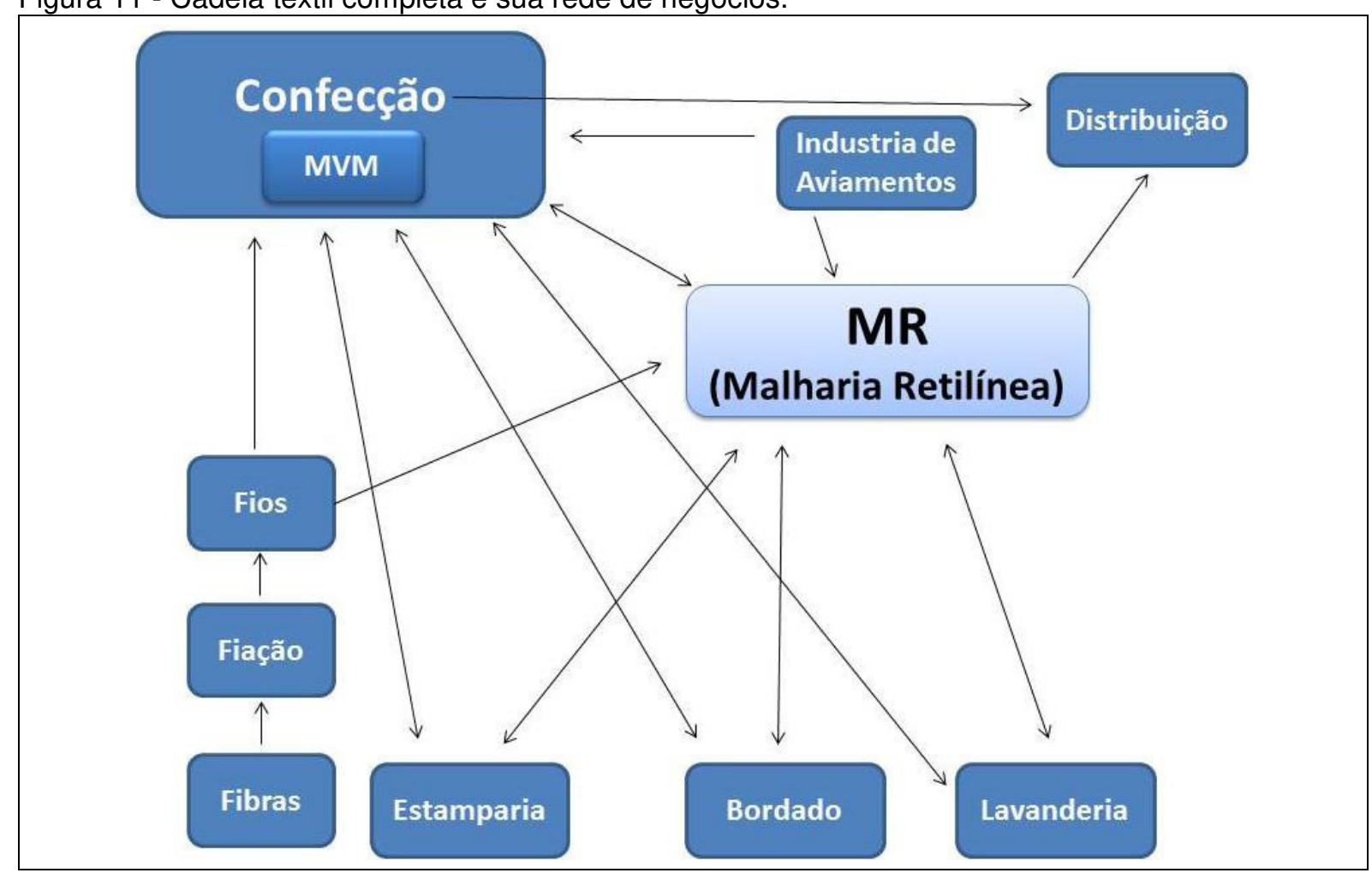

Fonte: adaptado de Mendes (2010). 
Castiglioni (2010) completa que o potencial da malharia se deve a alguns fatores, sendo alguns deles: a utilização de um número mínimo de fios, obedece a um fluxo "Gentil" de fios de uma malha a outra, que permite a variedade de espessuras de malhas, se obtém tecidos de face dupla e também simples, sobre tensão a malha tende a distorcer, permite a transferência da malha de uma frontura para outra.

Em uma indústria de malha o foco principal é a manufatura de tecidos de malha, que por sua vez originam-se por meio do uso da matéria-prima conhecido como fio. Este campo é abrangente e comporta, em sua maioria, vestimenta para mulheres, homens e crianças em desenvolvimento constante, e também pode ser encontrada em decoração (AQUINO, 2008).

Gatti (2014) assevera que produtos de tricô são continuamente inseridos em muitas áreas além do vestuário, e a sua empregabilidade se deve a algumas de suas propriedades, como resistência, caimento, aspecto suave, liberdade de movimentos do corpo por conta da sua forma elástica, facilidade na manutenção e propriedades térmicas.

A tecnologia de trama é muito diversificada e disseminada, sua atribuição é de quase um quarto da produção de tecidos para o vestuário. O maquinário de tecimento deste setor possui uma adequação para pequenos produtores, devido a alguns fatores como custo, rapidez e versatilidade (GATTI, 2014).

Segundo Mendes (2010), comparando o tecido de malha com o tecido plano, devido à produção ser mais rápida na malharia o custo deste acaba sendo mais baixo que o tecido plano. Ressalta ainda que a malha possui grande aceitação mercadológica que ocorre por serem práticas e versáteis.

Os tecidos são constituídos principalmente de fibras e entende-se estas como sendo a menor parte do tecido, que possui caráter químico definido. O seu peso, o calor, a aparência e seu desempenho são fatores determinantes que inferem na qualidade e destinação dos tecidos. As mesmas se dividem em dois grupos amplos, as chamadas fibras naturais que podem ser de origem vegetal, animal ou mineral que fazem parte do primeiro grupo, e as químicas que compreendem origem artificial ou sintética e são classificadas no segundo grupo (CHATAIGNIER, 2006; JONES, 2005; UDALE, 2009). As fibras têxteis possuem propriedades que as tornam diferentes umas das outras acarretando uma seleção para a produção dos tecidos, atribuindo a estes caráteres 
diversificados. Tais fatores estão relacionados à finura de uma fibra, pois a espessura contribuirá para toque e suavidade do produto, a elasticidade também é relevante, pois indica a capacidade de alongar-se. Quanto ao fator resistência, certas fibras são capazes de retornar a sua origem após terem sofrido amarrotamento. $O$ toque, por sua vez, está relacionado com sensações de conforto (PEZZOLO, 2007).

As fibras dão origem aos fios e estes podem obter comprimentos diferentes, chamados de "filamentos contínuo" compostos por fibras longas e contínuas, e "fibra descontínua" composta por fibra curta. Todavia, os fios também podem ser feitos de uma mistura de ambas, que se justifica devido à busca de resistência, design e por motivos econômicos (SISSONS, 2012).

As estruturas da manufatura são realizadas no tecimento, uma diversidade de agulhas e fios tanto como cores e pontos são utilizados para a criação de padronagens e texturas. A qualidade de um tecido de malha pode ser enfatizada pelos pontos empregados nesta etapa, além do mesmo proporcionar decoração ao vestuário (UDALE, 2009).

São consideradas duas categorias, segundo Udale (2009) e Sissons (2012). A chamada máquina monofrontura se caracteriza por conter um só conjunto de agulhas e é utilizada normalmente para fabricação de um tecido de malha simples e básica, com ponto meia, na qual a visualização do tecido é melhor e mais fácil de se entender Ainda Udale (2009) e Sissons (2012) a segunda categoria é a dupla frontura com dois conjuntos de agulhas opostas, que oferece maior flexibilidade, na qual é possível produzir uma malha dupla ou ribana, além de permitir inúmeras possibilidades de pontos. Devido a sofisticação e evolução na indústria de malhas, completa Sissons (2012), existem maquinários de quatro fronturas em uma mesma máquina, que oferecem tecimentos diversos quanto a espessura de fios e padronagens. Estas necessitam de investimento e sistema de programação, mas por sua vez oferecem um vestuário completo.

Sissons (2012) relata que em 1970, a chegada da máquina Shima Seik foi responsável por trazer o conceito de peças inteiras (sem costuras). Uma década depois (1980) a este lançamento a empresa já havia informatizado o seu maquinário por completo.

Ganzer et al. (2012) complementa que pode detectar a implantação de máquinas retilíneas que trabalham com tecnologia (diminuída) peça pronta, com o propósito de 
também aderirem às questões de gestão ambiental, uma vez que este processo pode até levar mais tempo em sua produção, mas tem a vantagem de não gerar sobras de materiais e as roupas serem diretamente encaminhadas para a costura.

Os produtos de malharia se diferenciam na aquisição de novas máquinas que possuem tecnologias mais avançadas. Permitindo desta maneira a fabricação de produtos em grande quantidade, bem como, uma maior qualidade, possibilitando elaborar produtos diferenciados com maior valor agregado reduzindo custos e aumentando possíveis lucros (SEVEGNANI; SACOMANO, 2008).

Tradicionalmente na técnica de tecimento em máquinas retilíneas do vestuário de malha, as peças são estabelecidas em três partes: frente, costas e a manga, distintas entre si, e que depois são costuradas. Com o desenvolvimento e a tecnologia surgiram processos de malharia onde se obtém uma peça confeccionada tridimensionalmente, que já sai assim diretamente da máquina de tecimento. Com este avanço é possível a eliminação ou redução de fases da produção da roupa (MALDONADO, 2005).

Conforme se pode verificar no Gráfico 4, a média das máquinas retilíneas instaladas no Brasil entre os anos de 2008 a 2012 representam a grande maioria, equivalente a 43.741, identificando um crescimento considerável neste segmento da cadeia têxtil.

Gráfico 4 - Média das máquinas instaladas por tipo no Brasil entre os anos de 2008 a 2012.

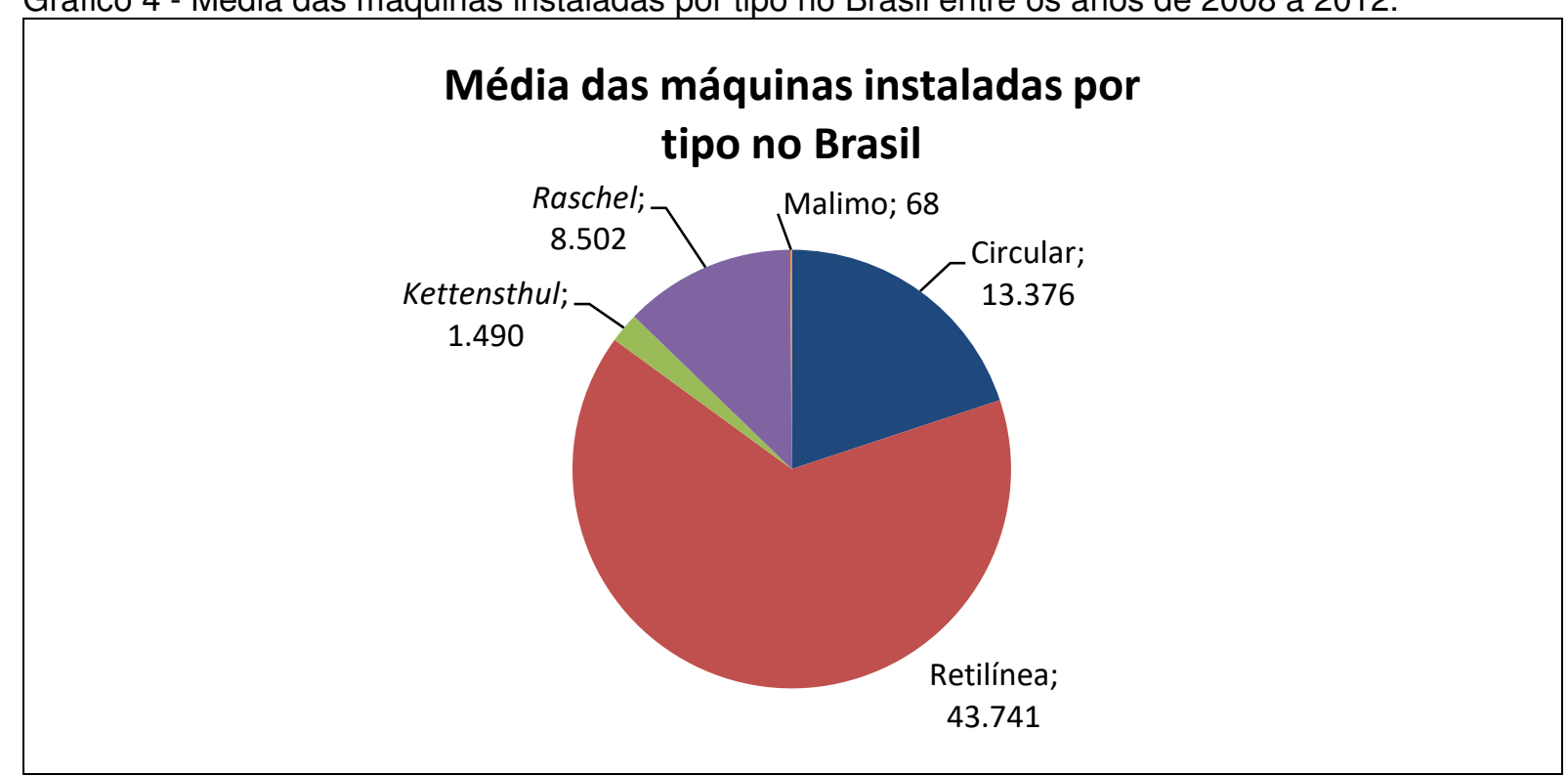

Fonte: adaptado de IEMI (2013).

O vestuário de malharia integral, ou seja, aquele que é concebido com a peça pronta e finalizada diretamente do maquinário, necessita de menos recursos do que o vestuário que tem a peça confeccionada com método de cortar e costurar. $\mathrm{O}$ autor 
ainda acrescenta que o uso do maquinário integral permite a realização de vestimentas únicas e customizadas com velocidade, se tornando desta maneira desnecessário o aguardo de fechamento de pedidos de malha em quantidade. Malhas podem ser fabricadas em três dimensões de forma direta na máquina, dispensando costuras. No caimento das roupas, drapeados podem ser criados e ao mesmo tempo lãs pesadas e macias podem ser usadas (JONES, 2005; MENDES, 2010).

Sofisticadas curvaturas vem sendo inseridas à tecnologia, que está disposta para a fabricação de formas em três dimensões. No campo da malharia retilínea, as técnicas inventadas (Fully Fashioned e Whole Garment Half-Gauge) permitiram o desenvolver de estruturas mais complexas, e estas são empregadas na fabricação de vestuário, bem como na produção de tecidos técnicos (PIRES; AVELAR; SANCHES, 2012).

Máquinas eletrônicas são consideradas de grande sofisticação, pois algumas delas possuem grande quantidade de fronturas de agulhas, acarretando uma multiplicidade no desenvolvimento de formas e texturas. Os dois fornecedores principais que oferecem esta possibilidade de desenvolvimento de roupa por completo são Shima Seik e Stoll (SISSONS, 2012).

Na Figura 12 pode-se notar o processo produtivo do vestuário da malharia retilínea sendo dividido quanto a sua forma de tecelagem, visto que quando se utiliza máquina eletrônica com processo painel posteriormente serão geradas as etapas de confecção que incluem modelagem, enfesto e corte, montagem da peça, costura e acabamento. Neste sentido pode-se visualizar que quanto ao procedimento adotado com máquinas eletrônicas integrais as etapas são reduzidas, pois a modelagem é computadorizada, o tecimento é programado obtendo a peça pronta que necessita apenas de arremates finais. 
Figura 12 - Processo produtivo de malharia retilínea envolvendo tecelagens eletrônicas e eletrônicas integrais

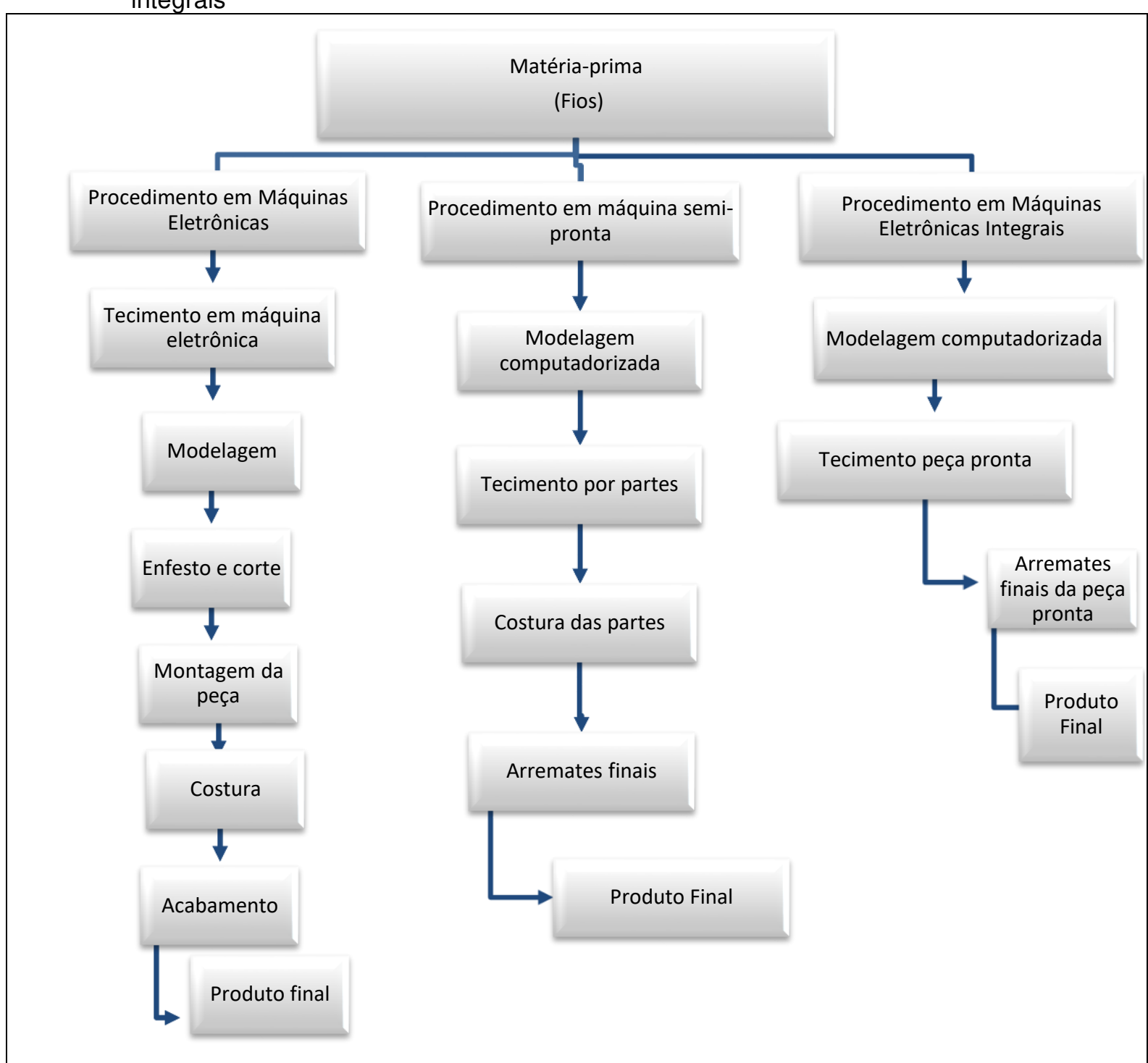

Fonte: baseado em Sissons (2012), Mendes (2010) e Roos (2001).

Para Roos (2001), na confecção da MR se torna primordial a utilização da mão de obra, assim como o auxílio de diferentes maquinários, que são relevantes para as atividades onde se concentrarão as montagens do vestuário, constituídos por operações de costurabilidade e acabamentos. Nesta fase se faz uso dos maquinários como mostra a Figura 13. 
Figura 13 - Etapas de confecção da MR.

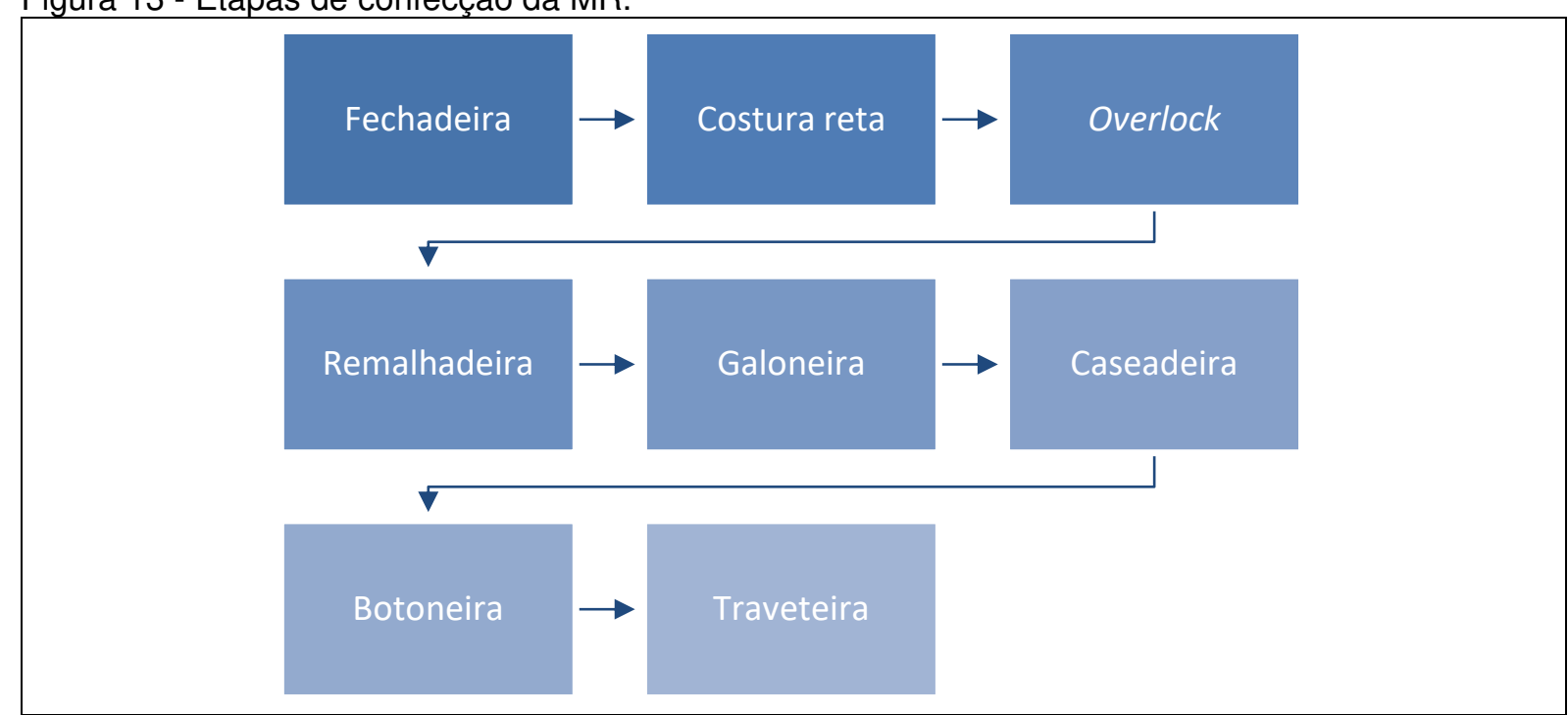

Fonte: baseado em Roos (2001).

O maquinário descrito na Figura 13 tem como especificidade o desenvolvimento de vestuário na malharia retilínea. Assim cada um desenvolve seu papel de acordo com as necessidades da malha. A fechadeira é responsável pelo fechamento das peças. A costura reta na malharia tem a função de colaborar com acabamentos e detalhes, tais como pregar um zíper, bolso ou etiquetas. O overloque, no entanto, faz o fechamento da roupa como nos ombros, nas laterais e mangas. A remalhadeira insere acabamentos finais ou terminações como golas e aberturas diversas. A galoneira também é direcionada para acabamentos. A caseadeira é específica para casa de botão e a botoneira fixa o botão na roupa, e, por fim a traveteira que executa arremates finais ou travetes (ROOS, 2001).

\subsection{IMPACTOS AMBIENTAIS DO SETOR TÊXTIL}

Questões ambientais voltadas ao setor têxtil têm ganhado cada vez mais atenção por parte do governo e dos fornecedores. Isso ocorre devido ao consumo excessivo de recursos e às emissões de poluentes (ZHANG et al., 2015). Neste setor, em todas as suas etapas, são gerados aspectos ambientais, a maioria efluentes líquidos, resíduos e emissões específicas do processo industrial deste setor, que se não forem controlados devidamente causarão danos ambientais, devido ao seu potencial (MACHADO JUNIOR; TORQUETTI, 2014). 
Comumente, fabricações padronizadas causam efeitos negativos colaterais. A indústria têxtil, por sua vez é um exemplo notório, pois quando os tecidos são tingidos consomem água limpa e quando esta retorna das indústrias estão contaminadas com metais pesados e outros. Grande parte dos materiais da produção têxtil provém de base petroquímica, então tanto a fabricação do próprio tecido quanto o lodo gerado neste período e o descarte do produto final não podem ser depositados no ecossistema de modo seguro (BRAUNGART; MCDONOUGH, 2013).

Os principais impactos ambientais provenientes das indústrias têxteis se encontram nas seguintes áreas: uso de energia e produtos tóxicos, bem como consumo de água, produção de efluentes químicos e geração de resíduos sólidos (BERLIM, 2012).

Segundo Machado Junior e Torquetti (2014) em todas as etapas do setor têxtil é possível encontrar aspectos e impactos ambientais, como se pode observar no Quadro 4.

Quadro 4 - Resumo dos aspectos e impactos ambientais no setor têxtil.

\begin{tabular}{|l|l|}
\hline $\begin{array}{l}\text { Emissões } \\
\text { atmosféricas }\end{array}$ & $\begin{array}{l}\text { Os responsáveis pelas emissões atmosféricas das indústrias têxteis são os } \\
\text { inúmeros produtos químicos usados no processo, principalmente caracterizados } \\
\text { por solventes orgânicos, ademais as caldeiras com a produção de vapor são } \\
\text { altamente poluidoras. }\end{array}$ \\
\hline $\begin{array}{l}\text { Resíduos } \\
\text { Sólidos }\end{array}$ & $\begin{array}{l}\text { Os resíduos sólidos são gerados no decorrer do processo produtivo em inúmeras } \\
\text { operações, havendo uma diversidade a respeito da quantidade e características. A } \\
\text { Lei Estadual no18031/09 apresenta diretrizes para se gerenciar corretamente os } \\
\text { resíduos sólidos. }\end{array}$ \\
\hline $\begin{array}{l}\text { Efluentes } \\
\text { Líquidos }\end{array}$ & $\begin{array}{l}\text { O têxtil é o setor que gera uma grande quantidade de efluentes líquidos, 150 litros } \\
\text { são utilizados para se produzir 1 kg de tecido, outra parte é perdida através da } \\
\text { evaporação. Os efluentes líquidos estão diretamente ligados à tecnologia e método } \\
\text { de produção da empresa. }\end{array}$ \\
\hline Ruído & $\begin{array}{l}\text { A fase da tecelagem é considerada intensa na geração de ruído, mas este também } \\
\text { ocorre em várias outras etapas do processo produtivo. A Lei Estadual no 10.100/90 } \\
\text { estabelece limites e parâmetros a serem seguidos. }\end{array}$ \\
\hline
\end{tabular}

Fonte: adaptado de Machado Junior e Torquetti (2014).

Bastian e Rocco (2009), mostram entradas e saídas que estão correlacionadas aos principais aspectos ambientais no Quadro 5, por conta de qualquer forma de matéria ou energia que se gera pelo desenvolvimento da atividade humana.

Quadro 5 - Entrada e saída de insumos de algumas etapas do processo produtivo têxtil.

\begin{tabular}{|c|c|c|}
\hline ENTRADA NO SISTEMA & PROCESSO & SAÍDA NO SISTEMA \\
\hline \multirow{3}{*}{$\begin{array}{l}\text { - energia elétrica; } \\
\text { - água; } \\
\text { - produtos químicos; } \\
\text { - sistema de } \\
\text { climatização. }\end{array}$} & \multirow{3}{*}{$\begin{array}{l}\text { - escolha da fibra; } \\
\text { - tecimento; } \\
\text { - confecção; } \\
\text { - acabamento. }\end{array}$} & $\begin{array}{l}\text { Poluição do ar: } \\
\text { - emissões atmosféricas; - emissões de ruídos. }\end{array}$ \\
\hline & & $\begin{array}{l}\text { Poluição do solo: } \\
\text { - resíduos sólidos }\end{array}$ \\
\hline & & $\begin{array}{l}\text { Poluição da água: } \\
\text { - efluentes líquidos: - efluentes orqânicos. }\end{array}$ \\
\hline
\end{tabular}

Fonte: adaptado de Bastian e Rocco (2009). 
Segundo Machado Junior e Torquetti (2014), aspectos ambientais, tais como os efluentes líquidos industriais, os resíduos sólidos e as emissões atmosféricas, intrínsecos ao processo industrial são constituídos durante todas as etapas de produção do setor têxtil. Estes aspectos, por sua vez, quando não controlados devidamente e mitigados, são altamente potenciais na geração de impactos ambientais relacionados à atividade.

Para Salcedo (2014) devido às proporções do setor têxtil e suas particularidades, que colaboram negativamente para com a sustentabilidade do meio ambiente, podem ser apresentados alguns efeitos do setor.

O uso exacerbado de produtos químicos para se produzir fios, tecidos e roupas, afetam principalmente o entorno aquático, também as etapas de produção para se fabricar um produto têxtil necessitam da utilização abundante de água e este uso pode trazer consequências para a sociedade. Quanto ao vestuário e seu processo de fabricação são geradores de diversos resíduos sólidos que estão implícitos ao longo do ciclo de produção e vida útil de um produto. Deste modo além das roupas que serão eliminadas em algum período abrange-se também os materiais das embalagens (SALCEDO, 2014).

Defende Fletcher (2007) que, o fato é que este descarte não é apenas de roupa, pois estão ali subentendidas oportunidades para negócios e para o design, mas a finalidade destes é o aterro sanitário. Para Berlim (2012) as roupas, lençóis, toalhas e outros são compreendidos como resíduos sólidos têxteis domésticos quando as pessoas os descartam em lixo doméstico, e são raras as pesquisas e dados sobre este assunto.

É gerado uma grande quantidade de resíduos têxteis no processo de se cortar uma peça, desta forma esta quantidade não fará parte da roupa por possuir tamanhos e formas impróprias e que geralmente serão descartados. Dentro deste contexto, 15\% de tecido que são utilizados pelas industrias se tornam resíduos (SALCEDO, 2014).

Perrels (2008) apud Niinimäki e Hassi (2011) trata que os questionamentos voltados à sustentabilidade, em grande parte não são apenas na produção e sistemas, mas também nos padrões de consumo.

É esperada uma inovação nesta indústria, mas para isso os critérios deverão ser mais rigorosos se tratando de conhecimento minucioso da produção dos seus suprimentos 
e do consumo. O impacto causado ao meio ambiente está cada vez mais ligado aos produtos, máquinas, insumos, processos, formas e métodos de organização do trabalho (SALCEDO, 2014).

Para Bastian e Rocco (2009) além de obrigações formalizadas e inseridas na regularização ambiental, a busca pela sustentabilidade tem guiado muitas indústrias em direção à prática de melhorias contínuas que visam a limpeza, organização, otimização de tempo de produção, assim como saúde, segurança, redução de potencial poluidor, almejando obter uma série de benefícios, sejam eles ambientais ou econômicos, na gestão de seus processos. Pode-se ver no Quadro 6 alguns exemplos de boas práticas para que ocorram tais benefícios ao ambiente.

Quadro 6 - Exemplos de boas práticas ambientais para o setor têxtil.

\begin{tabular}{|c|c|c|c|c|}
\hline & ETAPA & BOAS PRÁTICAS & $\begin{array}{l}\text { BENEFÍCIOS } \\
\text { AMBIENTAIS }\end{array}$ & $\begin{array}{c}\text { ASPECTOS } \\
\text { ECONÔMICOS }\end{array}$ \\
\hline $\begin{array}{l}\text { Redução do } \\
\text { consumo de } \\
\text { água }\end{array}$ & $\begin{array}{l}\text { Lavagem do } \\
\text { material } \\
\text { têxtil. }\end{array}$ & $\begin{array}{l}\text { Utilizar diversas lavagens } \\
\text { com quantidade reduzida } \\
\text { de água, ao invés de única } \\
\text { lavagem com grande } \\
\text { quantidade de água. }\end{array}$ & $\begin{array}{l}\text { Redução no } \\
\text { consumo de } \\
\text { recursos } \\
\text { naturais. }\end{array}$ & $\begin{array}{l}\text { Redução no uso } \\
\text { de produtos } \\
\text { químicos. }\end{array}$ \\
\hline $\begin{array}{l}\text { Redução e } \\
\text { conservação } \\
\text { de energia }\end{array}$ & $\begin{array}{l}\text { Instalações } \\
\text { de geração e } \\
\text { distribuição } \\
\text { de vapor. }\end{array}$ & $\begin{array}{l}\text { Monitorar constantemente } \\
\text { as caldeiras, com } \\
\text { regulagem de combustão, } \\
\text { controle de incrustações e } \\
\text { fuligem, e ponto de } \\
\text { carregamento (entre } 80 \% \\
\text { e } 90 \% \text { da capacidade } \\
\text { nominal). }\end{array}$ & $\begin{array}{l}\text { Redução do } \\
\text { consumo de } \\
\text { vapor em } \\
\text { torno de } 20 \% \\
\text { a } 30 \% \text { com } \\
\text { consequente } \\
\text { redução de } \\
\text { energia. }\end{array}$ & $\begin{array}{l}\text { Redução com os } \\
\text { custos e na taxa } \\
\text { de consumo de } \\
\text { energia. }\end{array}$ \\
\hline $\begin{array}{l}\text { Reutilização } \\
\text { de resíduos } \\
\text { sólidos }\end{array}$ & $\begin{array}{l}\text { Fiação, } \\
\text { tecelagem e } \\
\text { confecção. }\end{array}$ & $\begin{array}{l}\text { Reutilização dos retalhos } \\
\text { de tecidos gerados em } \\
\text { confecções ou vestuários. } \\
\text { Reutilização dos resíduos } \\
\text { têxteis das etapas de } \\
\text { fiação e tecelagem no } \\
\text { início do processo. }\end{array}$ & $\begin{array}{l}\text { Redução no } \\
\text { consumo de } \\
\text { recursos } \\
\text { naturais. }\end{array}$ & $\begin{array}{l}\text { Redução de } \\
\text { consumo de } \\
\text { matéria-prima } \\
\text { evitando-se o } \\
\text { desperdício de } \\
\text { material que pode } \\
\text { ser reaproveitado. }\end{array}$ \\
\hline $\begin{array}{l}\text { Recuperação } \\
\text { de produtos } \\
\text { químicos }\end{array}$ & Tingimento. & $\begin{array}{l}\text { Reutilizar as sobras dos } \\
\text { corantes de tinturaria para } \\
\text { formulação de cores } \\
\text { escuras. }\end{array}$ & $\begin{array}{l}\text { Redução do } \\
\text { consumo de } \\
\text { produtos } \\
\text { químicos. }\end{array}$ & $\begin{array}{l}\text { Redução na } \\
\text { quantidade de } \\
\text { produto químico. }\end{array}$ \\
\hline
\end{tabular}

Fonte: adaptado de Machado Junior e Torquetti (2014)

Alguns dos desafios principais que a indústria têxtil enfrenta com relação a redução de impacto ambiental, segundo Salcedo (2014), são: reduzir o consumo de água e o consumo de componentes químicos na produção de têxteis; desenvolver rotinas de lavagens de roupas que melhorem o consumo de água no processo produtivo; reduzir o uso direto e indireto de energia nos produtos têxteis; estender o tempo de vida útil dos produtos; utilizar de modo satisfatório os resíduos sólidos oportunizando uma 
nova vida a estes materiais, podendo reinseri-los novamente na produção como matérias-primas e; criar operações que diminuíam a quantidade de resíduo têxtil gerado seja junto aos fornecedores ou ao fim da vida útil dos produtos.

Segundo Alkaya e Demirer (2014) diversas técnicas/tecnologias foram investidas com a finalidade de se reduzir os gastos em energia, água e químicos, e em muitas fábricas têxteis já se tem obtido sucesso.

Verificou-se que há muitas vantagens em se implantar recursos voltados a sustentabilidade, entre elas temos a redução de poluição, a saúde, o ambiente, os trabalhadores e a comunidade que estão envolvidos a estas modificações. Estudos indicaram a possibilidade de se alcançar uma redução entre 15\% e 79\% no consumo de água (ALKAYA; DEMIRER, 2014).

Segundo Provenzano (2014) e Salcedo (2014) a moda sustentável está ligada a todo o processo produtivo, não abrangendo somente tecidos ecologicamente corretos. $O$ desenvolvimento industrial nos últimos vinte e cinco anos tem alcançado melhorias ambientais, consequentemente contribuindo para a redução do impacto ambiental. Todavia, juntamente com o crescimento da produção e do consumo aumentaram em níveis iguais os benefícios ambientais e os avanços ecológicos (THRONE-HOLST et al., 2007 apud NIINIMÄKI e HASSI, 2011).

É um desafio a necessidade em se desenvolver técnicas novas e eficientes no reaproveitamento de resíduos sólidos têxteis sintéticos advindos na indústria de confecção e vestuário enfrentada pelas empresas afim de conseguir manter uma competitividade em um mercado que é cada vez mais exigente em questões de produção sustentável (MARTINS et al., 2014).

Produtos podem ser mais importantes em sua fase de usabilidade contribuindo para a diminuição de consumo de água e energia se comparados à fase de produção do mesmo, isso pode ser verificado em estudos de análises do ciclo de vida em certos produtos (SALCEDO, 2014).

Cardoso (2008) defende que cabe ao design refletir cada vez mais sobre ciclo de vida do objeto projetado, procurando gerar soluções que otimizem fatores como a usabilidade de materiais não poluentes, eficiência de operação e potencial de reutilização. Salcedo (2014) completa que é importante repensar e redefinir a forma 
de desenhar assim como produzir, distribuir e utilizar as roupas. Estes são desafios que deve ter início já na fase de concepção da mesma.

Uma das maneiras que podem contribuir para esta minimização de resíduo têxtil seria incorporar o mesmo na própria fabricação da roupa em partes estratégicas como forro e entretelas, ainda deste modo seria possível manter um uso do mesmo material facilitando o processo de reciclagem da roupa (SALCEDO, 2014).

\subsection{DESIGNE O MEIO AMBIENTE}

O mundo material sofre influências e modelagens feitas através das ações dos designers. A grande maioria dos trabalhos de design tem uma relação próxima com o comercial, no qual são transformadas matéria e energia em produtos, que depois acabam em resíduos, em quantidade crescente, e com o intuito de garantir mais vendas a um negócio próspero. Porém estas ações dentro de um modelo econômico, são consideradas como inibidoras de mudanças maiores no que se refere à sustentabilidade (FLETCHER, 2007).

Cardoso (2008) diz que o que hoje conhecemos como face do movimento ambientalista veio a tomar forma no final da década de 1960, embora já fossem existentes no século XIX as preocupações com impacto ecológico negativo do industrialismo. Assim, no ano de 1972 foi motivada a primeira conferência mundial sobre o meio ambiente, impulsionada pela consciência política do problema.

Ainda Cardoso (2008), afirma que em 1992 consólidou-se definitivamente a partir da segunda conferência da ONU, o movimento ambientalista. O design, por sua vez, diante deste panorama ambiental vem se mostrando de forma discreta inserido no movimento. Assim, uma demonstração de consciência elevada com relação à ecologia se deve ao fato dos designers estarem próximos do processo industrial. Diferentes etapas na evolução histórica do ambientalismo têm transcorrido, e cada uma se relacionou a uma visualização distinta de como seria um design ambiental, ou ecodesign.

É crescente na indústria de moda a apresentação de alternativas sustentáveis e estas justificam-se necessárias devido a mudanças nas formas de produção e consumo. No 
que diz respeito a soluções sustentáveis tem ocorrido nas abordagens de ecodesign que tem sofrido evoluções para abordagens de design de sistemas para sustentabilidade (ANICET; MÉA; CAMPOS, 2012).

Práticas de design em tempos de sustentabilidade foram impulsionadas pelas ideias e habilidades dos designers, colocando-se em foco objetivos que estão além da comercialização. Para se estabelecer uma relação da sustentabilidade com a prática do design, se faz necessário revelar potencialidades em situações não convencionais. Assim interagir com outros setores da economia ou mesmo rever setores que já existem sob uma nova visão, elaborando mais chances para que os designers pratiquem suas habilidades em prol da sociedade bem como da ecologia (FLETCHER, 2007).

O design encontra-se hoje em pensamentos inclinando-se em relação às forças econômicas e ecológicas, bem como influências culturais e sociais maiores que trazem obrigatoriamente a necessidade de se reavaliar os sistemas de valores que predominam no design e dos locais em que tradicionalmente habilidades do designer são aplicadas. Como uma resposta deste contexto, inicia-se uma exploração em relação ao potencial dos designers para assim haver uma transformação inesperada das coisas (FLETCHER, 2007).

Para Dormer (1995) o fenômeno do consumismo que decorreu naturalmente da segunda guerra mundial trouxe a preocupação pela conservação e ecologia. Há também uma probabilidade que o design de produtos com grande durabilidade e qualidade sejam privilegiados. Para Sant'anna (2009) a moda está interligada historicamente ao mundo industrial, desta forma a revolução industrial é intensamente atrelada à moda, pois a mesma se estabeleceu e alterou a vida moderna devido à inserção do maquinário têxtil.

Padrões de pensamentos e de comportamento iniciam uma mudança quanto à inovação sistêmica e de sustentabilidade, assim levando a elaboração de práticas e estruturas que relatam e delimitam a atividade econômica, inseridas em limites ecológicos. Ainda acrescenta a autora que a grande maioria das atividades de empreendedorismo de design alocaram-se em um posto na internet, pois oportunidades são oferecidas a respeito de inovação e sustentabilidade, com modelos de negócio alternativos, de redes novas e canais de comunicação. Assim novas possibilidades são visíveis, pois os designers empreendedores não irão produzir 
pensando em produtos inovadores direcionados a empresas que já existem, em contrapartida se dedicarão a uma maneira de raciocinar de forma mais fecundante $e$ inovadora tornando possível uma transformação na própria indústria (FLETCHER, 2007).

Berlim (2012) assevera que na moda, o design deverá demonstrar um relacionamento rente ao consumidor e Fletcher (2008) apud Berlim (2012), contempla que este ajustamento denominado de "design participativo", faz a junção entre designers e usuários. A este, por sua vez, cabe o procedimento tanto da criação quanto da produção, dividindo estas ações entre os indivíduos como costura, modelagem, corte e outros. Deste modo o consumidor oculta-se e aparece a ação do ser humano trocando suas sabedorias.

Uma abordagem estruturada pode ser considerada uma estratégia de design sustentável. Está é criada com a intenção de colaborar na redução dos impactos ambientais e/ou sociais ligados a produção, ao uso e também ao descarte de um produto (GWILT, 2014).

A "formação cultural" disseminada como essencial para um profissional de design se dá por meio de um processo desenvolvido e cultivado ao longo de suas experiências e hábitos que devem ser cultivados. Portanto, fazem-se necessários para o exercício da criatividade do profissional, momentos de relaxamento para que se permita encontrar e experimentar novos horizontes (SANT'ANNA, 2009).

\subsubsection{O design na manufatura do vestuário de moda em malharia retilínea (MVMMR)}

Segundo Motta e Conti (2014) o fio que compõe uma malha, não é simplesmente um fio, mas sim um condutor que vai além das junções de fibras e que pode inspirar uma arte, um objeto em três dimensões, um produto para vestir. A malharia juntamente com suas técnicas e misturas de materiais é provavelmente um dos saberes manuais mais antigos do mundo. Hoje no design, a estética e a sensibilidade se unem à evolução tecnológica criando uma estrada entre tradição e modernidade na qual o designer vem inserido. 
Na Manufatura da Malharia Retilínea (MMR) técnicas de produções tridimensionais podem ser exploradas na textura e na superfície das malhas por meio de pontos, bem como pela utilização de diversificados fios e suas gramaturas. Torna-se relevante fazer uso de uma ficha técnica para servir de auxílio e devem ser reunidas também as amostras registradas da tensão das malhas e adequação ao design, mantendo sua ficha técnica a cada desenvolvimento (SISSONS, 2012).

A amostra por sua vez é o caminho que permite que na MMR se desenvolva um cálculo com quantidade de carreiras a fazer e a quantidade de agulhas necessárias para um aumento ou diminuição da malha durante a confecção. Comumente se realiza uma amostra individual direcionada para cada peça que se deseja confeccionar (SISSONS, 2012).

O maquinário eletrônico da malharia retilínea permite ao designer um amplo repertório para o desenvolvimento de padronagens, de pontos coloridos simbólicos, ou os dois, além de possibilitar a visualização da ideia de como ficaria a peça finalizada (SISSONS, 2012).

Anicet e Rüthschilling (2013) afirmam que a sustentabilidade é pensada como um fator extra por muitos designers e, portanto, pode ser considerado posteriormente. O que ocorre atualmente é que se está em transição no processo de conscientização dos consumidores e a prática sustentável dos designers é necessária para que se modifiquem os projetos desde o seu início, inserindo ao mesmo o conceito da sustentabilidade como fator prioritário. Berlim (2012) acrescenta que em relação aos estudos feitos no Brasil, a questão ambiental é prioritária, por ser entendida e tida como importante. Completa que algumas marcas que abordam questões sociais e ambientais são reconhecidas por seu relacionamento.

Na moda, para Sant'anna (2009), as alterações e características da mesma nos encaminham para transformações mais amplas e complexas relativas à maneira de ser, tanto quanto de sentir e de raciocinar de uma sociedade. Para Cardoso (2008) as reações do design brasileiro são as mais diversas se tratando dos desafios ambientais. Nos últimos anos tem-se visto desde o reaproveitamento de materiais descartados, até a gestão racional de processos industriais e construtivos.

Para Sissons (2012), há contrastes no design e na produção de malhas e, apesar dos avanços e do design estarem interligados ao crescimento tecnológico, o vestuário de 
luxo constantemente está ligado ao trabalho manual. Assim técnicas antigas e de tradição estão sendo misturadas a novos e inovadores designs. Em retorno ao sucesso da produção em massa, nota-se uma crescente valorização relacionada a roupas lentas "slow clothes", e das peças feitas com exclusividade, que por sua vez são mais pessoais para o usuário.

É notável que as tecnologias evoluam, e são necessárias para a resolução de problemas. Porém o designer e sistemas de gestão de qualidade vêm de forma crescente sendo vistos como instrumentos fundamentais para a projeção e usabilidade de forma mais eficiente de recursos, por meio da elaboração de consumo e da eliminação do desperdício (CARDOSO, 2008).

Ainda Cardoso (2008) completa que o design vê a necessidade de raciocinar sobre o ciclo de vida do produto de maneira difundida, levando em conta um pós-uso que permite prolongar um futuro indeterminado.

Novos meios e novas formas de desenvolver o produto podem ser empregados na moda a fim de reduzir os impactos. Como exemplo tem-se a inserção do conceito de ciclo de vida do produto na moda, sugerindo uma alteração no projeto do produto, sobretudo em suas etapas de desenvolvimento, seja na área têxtil ou na confecção (ALMEIDA; MOURA, 2012).

A produção sustentável, para Dias (2014), objetiva o desenvolvimento de estratégias que contribuam para um aumento na produção e da eficiência dos meios, nos diversos processos que ocorrem no ciclo de vida.

Três aspectos importantes devem ser levados em consideração pelos designers: sociedade, meio ambiente e economia. $O$ desafio é encontrar uma forma de gerenciar estes aspectos relevantes de modo responsável. Ainda que os designers estejam conscientes dos impactos ambientais relativos tanto as fibras quanto aos tecidos, é também relevante analisar as oportunidades que vão além da escolha dos materiais (GWILT, 2014).

Neste contexto pode-se analisar que, segundo Fletcher e Grose (2011), a designer Karina Michel trabalha com o reaproveitamento dos resíduos têxteis de tricô de uma empresa, incluindo em seu desenvolvimento itens descartados e sobras de tecidos. Ao transformar resíduos têxteis em roupa confeccionada perfeitamente, dá-se um exemplo do designer com capacidade para inovar em questões sustentáveis. Este 
método de acordo com Ruthschilling et al. (2014) tem o objetivo de diminuir a produção a partir de "têxtil virgem" e a procura aos recursos naturais, além de ser um procedimento que inova na reciclagem de resíduos têxteis, é considerado um dos conceitos do upcycle.

Verifica-se, segundo Matos e Bezerra (2012), que a indústria de moda e vestuário vem se adequando a opções sustentáveis. $O$ desenvolvimento de acessórios de moda a partir de resíduos têxteis é passível de ser adotado por empresas, pois além de gerar lucro mostra sua contribuição ética e sustentável.

Outra designer relacionada com questões sustentáveis, de acordo com Morelli (2010) e Schulte (2011), é Sandra Backlund, designer sueca que desenvolve peças do vestuário feitas manualmente com materiais diferenciados e tem sido chamada de precursora do movimento slow fashion.

A designer elabora criações com espessuras de malha diversificadas, trabalha com volumes de forma exacerbada e ao mesmo tempo com tricôs finíssimos, leves e transparentes, cria design de forma artesanal e aspectos vistos em suas coleções.

A técnica de design zero waste consiste em um processo de design integrado, onde caminham juntas a concepção e o fornecimento. Assim se faz necessário um conhecimento em relação às dimensões para ter a capacidade de projeção do vestuário, calculando o seu projeto em relação ao seu tecido. Isso é fundamental, a partir do momento que não se deseja trabalhar com padrões de medidas prédeterminados. A designer Johanna Ho faz uso de desperdícios têxteis, cortando os tecidos que sobram em tiras finas e depois utilizando-os como matéria-prima (fios), tramando malhas que viram produtos (REDRESS, 2014).

Como demonstrado por Jack (2012, p.1 apud GWILT, 2014), o design de moda zero waste utiliza "avanços técnicos e conceituais na modelagem, produzindo peças de vestuário que utilizam todo o tecido, ourela a ourela". Gwilt (2014) vai além e afirma que, mais do que evoluções na modelagem, o design zero waste mostra a necessidade de alterar o método da produção e, principalmente, do design de moda, pois se deve raciocinar com relação ao desperdício antes mesmo de iniciar o design dos produtos (PEREZ; CAVALCANTE, 2014).

Além destes, muitos outros profissionais da moda estão inseridos em metodologias visando questões ambientais. Fletcher e Grose (2011) asseveram que os designers 
têm envolvimento em diversos setores, impulsionando novos padrões de design, de consumo e de comportamento. Desta maneira se correlacionam com a sociedade, instituições e culturas e com o decorrer dos anos podem conduzir mudanças sistemáticas.

O processo de incorporação de desenvolvimentos sustentáveis ainda é muito difícil em todas as fases conceituais e produtivas. É tarefa do design, escolher inicialmente o conceito de sua marca, profissionalizando-se e ao mesmo tempo buscando aperfeiçoamento (OENNING; NEVES; FESFOSCO, 2012). 


\section{METODOLOGIA E PESQUISA}

Esta pesquisa é de natureza qualitativa, a qual para Flick (2004) fundamenta-se em descobertas, tem embasamento em material empírico e seus métodos são aplicados ao objeto de estudo de forma adequada e selecionada. O autor contempla ainda que os métodos qualitativos acreditam na comunicação do pesquisador com o campo e seus membros como parte evidente da produção do conhecimento, tornando-se componente do processo da pesquisa as subjetividades do pesquisador, e também das pessoas que estão sendo estudadas.

Tem como modalidade o estudo de múltiplos casos que, segundo Yin (2001), ressalta uma vantagem, onde provas resultantes são consideradas mais convincentes, porém exige mais tempo e recurso do pesquisador. Ainda complementa que nesta metodologia de estudo é importante que se considere cada caso, e que este sirva a um propósito específico dentro do escopo global da investigação. Para Bruyne, Herman e Schouth (1977) este estudo tem como meta ir além da evidência única encontrada na empresa, permite analisar tanto suas semelhanças quanto suas dessemelhanças.

Para Eisenhardt (1989) é relevante unir ao estudo de caso, diferentes combinações, tendo em vista que isso amplia a fundamentação da pesquisa. Yin (2001) ainda completa que o relatório de múltiplos casos pode seguir uma série de perguntas e respostas, contidas no banco de dados do estudo de caso, gerando de forma compacta um resultado que oferece vantagens para o leitor que poderá fazer comparações cruzadas em interesses específicos.

Destaca-se que os estudos de caso, segundo Yin (2001), permitem uma investigação abrangente e significativa da vida real. Cooper e Schindler (2011) afirmam que o estudo de caso é uma combinação de análise de registros e observações, permitindose a realização de entrevistas individuais semiestruturadas. Os autores ainda contemplam a possibilidade de se entender o significado que as pessoas atribuem às suas experiências, no qual o pesquisador pode compreender e descrever melhor os acontecimentos.

Ainda para Cooper e Schindler (2011) o pesquisador pode escolher o tipo de entrevista, dentre elas há a semiestruturada onde inicia-se com algumas questões 
específicas e posteriormente segue-se o pensamento do entrevistado com indagações do entrevistador. Adotou-se para o trabalho entrevistas semiestruturadas e observação direta, e para embasar a aplicação das técnicas foi feita a revisão da literatura com relação ao campo de têxtil e moda.

No levantamento da revisão bibliográfica, procurou-se construir o embasamento teórico necessário para esta pesquisa, a qual fornece uma denotação mais aprofundada e contextos relacionados aos temas e enfoques abordados no presente trabalho. Os temas principais são: Produção mais Limpa, aspectos de conservação ambiental, a questão da produção visando melhorias no seu processo na manufatura do vestuário de moda no contexto da malharia, a questão da destinação dos resíduos sólidos têxteis gerados por este setor e outros que tivessem aproximação com o problema de pesquisa.

Para coleta de dados, foi conduzida uma pesquisa de campo junto a uma amostra constituída por seis (6) empresas do seguimento de malharia retilínea, situadas no polo industrial de Monte Sião - MG, afiliadas a Associação Comercial de Monte Sião (ACIMS). Os dados coletados serviram para verificar a adoção da Produção mais Limpa na malharia retilínea, e identificar como o setor está tratando de seus resíduos têxteis, e como estes estão sendo administrados pelas empresas.

Neste contexto se fez necessário um levantamento de dados gerais sobre as empresas de malharia da região. Este levamentamento foi desenvolvido tendo como principal fonte os dados advindos da entrevista com o presidente da ACIMS - João Tadeu Dorta Machado.

A seguir, é apresentada a questão fundamental norteadora da presente pesquisa. $E$, de maneira que possam ser estudados separadamente, são delineados, um a um, seus três subproblemas, juntamente com os dados necessários para enfatizá-los, suas fontes, suas respectivas técnicas de coleta e tratamento de dados empregados. Por fim, são apresentadas algumas das indagações exploratórias usadas para a orientação quanto ao levantamento e ao tratamento de dados respectivos a cada subproblema. 


\subsection{QUESTÃO FUNDAMENTAL NORTEADORA}

Que se pode depreender da pesquisa em relação ao impacto ambiental em empresas do segmento de malharia retilínea selecionadas no polo têxtil da região de Monte Sião, no Sul de Minas Gerais quanto à maior ou menor preocupação com a "Produção mais Limpa", tendo como foco principal os resíduos sólidos têxteis observando de maneira secundária a redução do uso de água e energia?

\subsubsection{Subproblema 1}

No subproblema 1 o foco é a redução da produção de resíduos sólidos. Apresenta-se a seguir sua indagação:

Que se pode depreender quanto à maior ou menor presença de preocupações de "Produção mais Limpa", quanto à redução do descarte dos resíduos sólidos têxteis em seis empresas selecionadas do setor de malharia situadas na região de Monte Sião?

Em que se estruturou os possíveis questionamentos aspectos relevantes sobre as malharias com relação à produção de resíduos sólidos têxteis. Foram entrevistadas seis malharias selecionadas no polo têxtil industrial da região de Monte Sião, no sul de Minas Gerais.

Exemplos de possíveis questionamentos que não se esgotam: Será que as malharias possuem direcionamento interno para seus resíduos têxteis? Será que as malharias possuem teares de última geração que auxiliem na minimização do resíduo têxtil? Qual será a finalidade dada a seus resíduos têxteis? Quanto de perda de material? Será que o processo de produção otimiza a utilização da malha? Como eles se informam e se atualizam? Como era no passado? Previsão para o futuro? Qual a quantia de resíduo sólido (tricô) recebida pela reciclagem/ mosteiro? Qual a maior dificuldade em trabalhar com o resíduo? Qual é o modo de separação? Qual a finalidade dada a cada resíduo? Qual é a época de maior recebimento de resíduo? 


\subsubsection{Subproblema 2}

No subproblema 2 o foco é a redução do consumo de água. Apresenta-se a seguir sua indagação:

Que se pode depreender quanto à maior ou menor presença de preocupações de "Produção mais Limpa", em termos da redução da utilização de água em seis empresas selecionadas do setor de malharia situadas na região de Monte Sião?

Para responder a esta questão verificou-se os aspectos relevantes sobre as malharias com relação à redução do consumo de água, tais como: equipamentos eventualmente preparados para redução do consumo de água. Reutilização eventual da água (empregada em maquinário ou águas de chuva).

Foram entrevistadas seis malharias selecionadas no polo têxtil industrial da região de Monte Sião no sul de Minas Gerais.

Em que se estruturou os possíveis questionamentos: Será que a malharia em questão possui algum sistema para economia de água? Será que há na empresa algum direcionamento para o reuso de água? Será que existe um tratamento de água após o uso? Será que utilizam pigmentos mais ou menos poluentes? Como era no passado? Previsão para o futuro?

\subsubsection{Subproblema 3}

No subproblema 3 o foco é a redução do consumo de energia. Apresenta-se a seguir sua indagação:

Que se pode depreender quanto à maior ou menor presença de preocupações de "Produção mais Limpa", quanto a redução de energia em seis empresas selecionadas do setor de malharia situadas na região de Monte Sião?

Para responder a esta questão verificou-se aspectos relevantes sobre as malharias com relação à redução do consumo de energia tais como: otimização do consumo quanto à utilização de lâmpadas, teares e maquinaria em geral. Foram entrevistadas 
seis malharias selecionadas no polo têxtil industrial da região de Monte Sião, no sul de Minas Gerais.

Em que se estruturou os possíveis questionamentos: Será que as empresas possuem alguma adequação racional quanto à iluminação do ambiente? Será que as empresas possuem teares de última geração que auxiliem no consumo reduzido de energia? Será que possuem alguma economia de energia no processo de produção? Como era no passado? Previsão para o futuro?

\subsection{QUADRO DA ESTRUTURA METODOLÓGICA DA PESQUISA}

Na sequência é apresentado o resumo da estrutura metodológica construída na presente pesquisa (Figura 14). 
Figura 14 - Quadro da estrutura metodológica da pesquisa

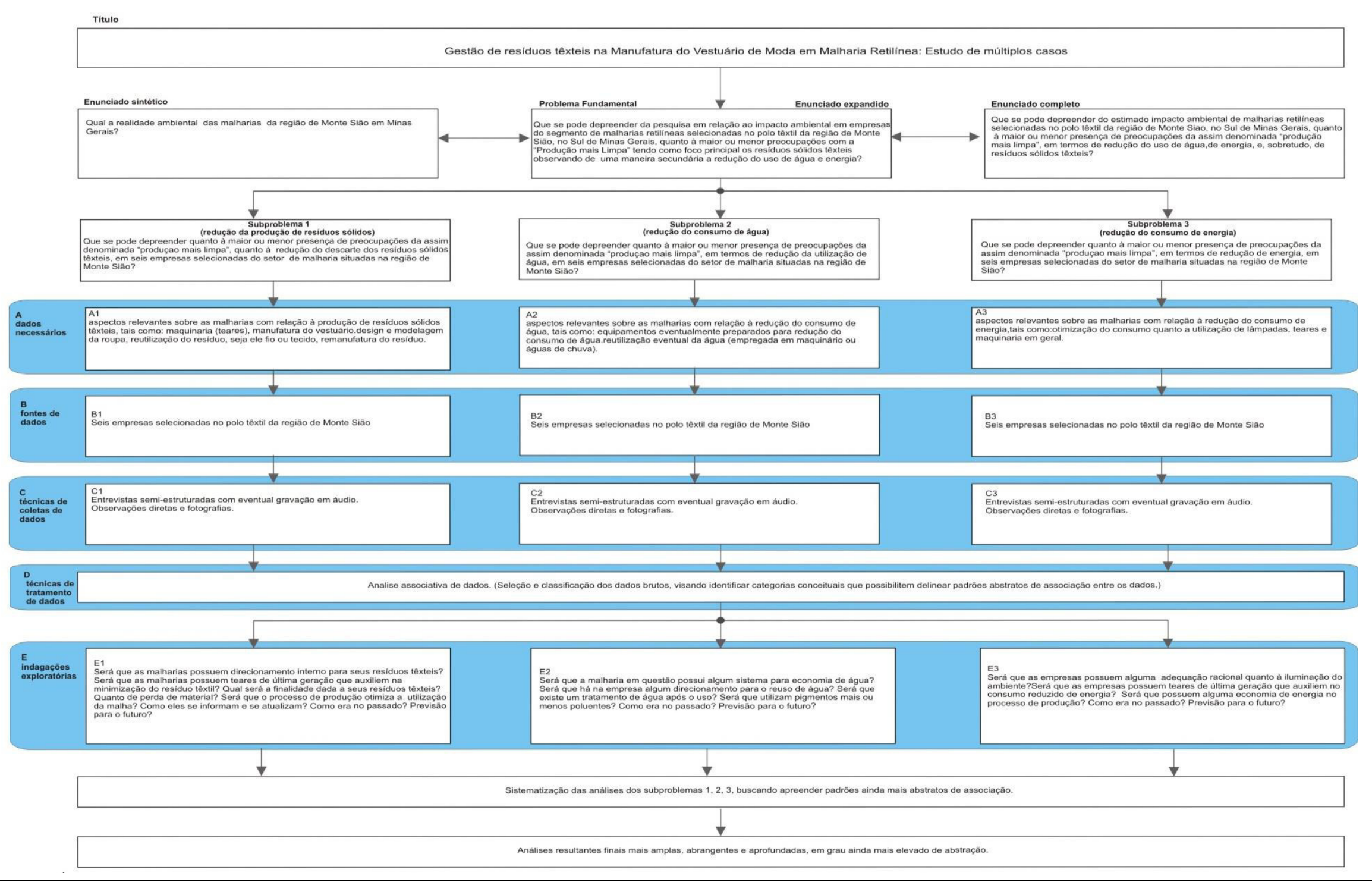




\subsection{ASPECTOS GERAIS DA SELEÇÃO DA AMOSTRA}

O presente trabalho será desenvolvido no contexto da indústria têxtil, uma cadeia extremamente poluidora em todas as suas etapas produtivas. O direcionamento desta pesquisa encontra-se no seguimento da malharia retilínea, pois são evidentes em seu processo produtivo todas as fases para compor o produto, desde a escolha da matéria-prima até a distribuição final. Trata-se um setor industrial em constante desenvolvimento e crescimento, espalhados em várias regiões, entre elas a região de Monte Sião - MG, "capital nacional do tricô".

Segundo Associação Comercial e Industrial de Monte Sião (ACIMS, 2016) o número de fábricas do setor é de 1,5 mil, tendo uma produção mensal de três milhões de peças e empregam 7,5 mil pessoas, número que representa $63 \%$ da população economicamente ativa.

Selecionaram-se seis empresas para compor a amostra a ser pesquisada, as quais não serão identificadas a pedido dos próprios entrevistados e proprietários. Estas empresas são de pequeno/médio porte, trabalham atacado e varejo, onde pretendese verificar menor ou maior presença de preocupações da "Produção mais Limpa" em termos da redução do uso de água, energia e sobretudo de resíduos sólidos têxteis.

Antes de realizar o estudo nas malharias foi realizada pesquisa de informações pertinentes ao setor na região, e entrevista disponibilizada pela Associação Comercial de Monte Sião (ACIMS, 2016).

Esta região foi escolhida por ser conhecida como "Circuito das Malhas", Monte Sião, cidade localizada no Sul do estado de Minas Gerais, nacionalmente denominada como a "Capital Nacional da Moda Tricô" que recebe este título devido ao seu parque industrial neste segmento, responsável por $85 \%$ da mão de obra do estado de Minas Gerais.

Segundo dados fornecidos pela ACIMS, desde a década de 60 na cidade 0 seguimento de malharia é considerado o de maior impacto econômico e social, possuindo assim, a maior concentração demográfica mundial de máquinas retilíneas.

A Tabela 1 traz alguns dados relevantes da capital nacional do tricô. 
Tabela 1 - Monte Sião em números.

\begin{tabular}{ll}
\hline \multicolumn{1}{c}{ DESCRIÇÃO DOS DADOS } & \multicolumn{1}{c}{ QUANTIDADE } \\
\hline Consumo mensal de fios & $800 \mathrm{mil}(\mathrm{kg})$ \\
Produção mensal & 3,0 milhões de peças \\
Preço médio de venda unitário & $28,00(\mathrm{R} \$)$ \\
Número de fábricas & $1,5 \mathrm{mil}$ \\
Número de lojas especializadas (showroom) & $1,5 \mathrm{mil}$ \\
Número de compradores nos fins de semana & $21 \mathrm{mil}$ \\
Número de empregados no setor de tricô & $7,5 \mathrm{mil}$ \\
\hline
\end{tabular}

Fonte: elaborado pela autora, 2016.

Dados fornecidos pela ACIMS apresentam que o faturamento médio mensal é de $\mathrm{R} \$ 30$ milhões, tendo uma produção média mensal de 3 milhões de peças, consumindo desta forma, 800 mil $(\mathrm{kg})$ de fio. Cidade turística que abarca nos fins de semana uma média de 21 mil visitantes (compradores).

\subsubsection{Apresentação do perfil das empresas selecionadas}

Foram realizadas visitas técnicas e entrevistas com roteiros semiestruturados respondidas por proprietários ou representantes das seis empresas, com o objetivo de verificar menor ou maior presença de preocupações da "Produção mais Limpa" em termos da redução do uso de água, energia e, sobretudo de resíduos sólidos têxteis. O Quadro 7 apresenta o perfil de cada empresa pesquisada na região. 
Quadro 7 - Perfil da Empresa

\begin{tabular}{|c|c|c|c|c|}
\hline & CARACTERÍSTICAS GERAIS & $\begin{array}{l}\text { DESENVOLVIMENTO DE } \\
\text { PRODUTO } \\
\end{array}$ & $\begin{array}{l}\text { PRODUÇÃO } \\
\text { MENSAL } \\
\end{array}$ & DISTRIBUIÇÃO \\
\hline EMPRESA “A” & $\begin{array}{l}\text { Está em funcionamento desde o ano de } 2010 \text { e atualmente } \\
\text { possui } 11 \text { funcionários (entre mão de obra interna e } \\
\text { representação de loja). Possui maquinário manual e eletrônico } \\
\text { totalizando } 7 \text {. Trabalha somente com moda feminina. }\end{array}$ & $\begin{array}{l}\text { É realizado internamente com os } \\
\text { proprietários da empresa e o processo } \\
\text { de modelagem terceirizado. }\end{array}$ & $\begin{array}{l}\text { Em torno de } \\
4.000 \text { a } 4.500 \\
\text { peças. }\end{array}$ & $\begin{array}{l}\text { Três lojas próprias } \\
\text { e uma } \\
\text { representação, } \\
\text { varejo e atacado. }\end{array}$ \\
\hline EMPRESA “B” & $\begin{array}{l}\text { Está em funcionamento desde o ano de } 1991 \text { e atualmente } \\
\text { possui } 10 \text { funcionários, tendo somente maquinário eletrônico } \\
\text { dentre elas duas de peça pronta totalizando } 7 \text { máquinas e } \\
\text { trabalha com moda feminina plus size. }\end{array}$ & $\begin{array}{l}\text { O desenvolvimento de produto e a } \\
\text { confecção são realizados internamente. }\end{array}$ & $\begin{array}{l}\text { Em torno de } \\
2.400 \text { peças. }\end{array}$ & $\begin{array}{l}\text { Três lojas próprias, } \\
\text { varejo e atacado. }\end{array}$ \\
\hline EMPRESA “C” & $\begin{array}{l}\text { Está em funcionamento desde o ano de } 1997 \text { e atualmente } \\
\text { possui } 15 \text { funcionários. Possui } 6 \text { máquinas eletrônicas e trabalha } \\
\text { com moda feminina plus size. }\end{array}$ & $\begin{array}{l}\text { O desenvolvimento de produto e a } \\
\text { confecção é realizado tanto } \\
\text { internamente quanto externamente. }\end{array}$ & $\begin{array}{l}\text { Em torno de } \\
3.750 \text { peças. }\end{array}$ & Uma loja, atacado. \\
\hline EMPRESA “D” & $\begin{array}{l}\text { Está em funcionamento desde o ano de } 1987 \text { e atualmente } \\
\text { possui } 40 \text { funcionários. Possui } 10 \text { máquinas eletrônicas de } \\
\text { diferentes finuras e trabalha com moda feminina e masculina. }\end{array}$ & $\begin{array}{l}\text { O desenvolvimento de produto interno } \\
\text { e a confecção tem parte terceirizada. }\end{array}$ & $\begin{array}{l}\text { Em torno de } \\
10.000 \text { peças. }\end{array}$ & $\begin{array}{l}\text { Duas lojas, atacado } \\
\text { e varejo. }\end{array}$ \\
\hline EMPRESA “E” & $\begin{array}{l}\text { Está em funcionamento desde o ano de } 1988 \text { e atualmente } \\
\text { possui } 21 \text { funcionários. Possui } 8 \text { máquinas eletrônicas e trabalha } \\
\text { com moda feminina e masculina. }\end{array}$ & $\begin{array}{l}\text { O desenvolvimento de produto e a } \\
\text { confecção são realizados internamente. }\end{array}$ & $\begin{array}{l}\text { Em torno de } \\
10.000 \text { peças. }\end{array}$ & $\begin{array}{l}\text { Uma loja, auto } \\
\text { atacado. }\end{array}$ \\
\hline EMPRESA “F” & $\begin{array}{l}\text { Está em funcionamento desde o ano de } 1990 \text { e atualmente } \\
\text { possui aproximadamente } 130 \text { funcionários. Possui } 10 \text { máquinas } \\
\text { eletrônicas e trabalha com moda feminina. }\end{array}$ & $\begin{array}{l}\text { O desenvolvimento de produto e a } \\
\text { confecção são realizados internamente. }\end{array}$ & $\begin{array}{l}\text { Em torno de } \\
20.000 \text { peças. }\end{array}$ & $\begin{array}{l}\text { Duas lojas, } \\
\text { atacado. }\end{array}$ \\
\hline
\end{tabular}

Fonte: elaborado pela autora

\footnotetext{
${ }^{1}$ Informações fornecidas pelas empresas em entrevista realizada pela autora no ano de 2016 e 2017.
} 


\section{DISCUSSÃO E ANÁLISE}

O presente capítulo apresenta os resultados do tratamento dos dados com a finalidade de responder os subproblemas 1, 2 e 3 . As fontes de dados, técnicas de coleta e de tratamento encontram-se detalhadas no Capítulo 3, correspondente ao método de pesquisa.

A obtenção dos dados tem como objetivo verificar a menor ou maior presença de preocupações da "Produção mais Limpa", tendo como foco principal os resíduos sólidos têxteis e observando de maneira secundária a redução do uso de água e energia.

\subsection{APRESENTAÇÃO E ANÁLISE DAS MALHARIAS}

Nesta seção serão apresentados os resultados das malharias pesquisadas, coletados por meio de um roteiro semiestruturado com todas as questões voltadas a ações relacionadas aos resíduos sólidos têxteis, sendo este o principal foco do estudo. Ademais, de modo menos abrangente, somente a Questão 1 tratou do benefício ao meio ambiente voltado para a redução do consumo de água e energia.

A partir das entrevistas formaram-se categorias de análise, sendo elas: (I) benefício ao meio ambiente (1: resíduo sólido, 2: água e 3: energia); (II) matéria-prima principal; (III) quantidade de resíduo têxtil por setor; (IV) resíduos separados por tipo; (V) recipiente de coleta; (VI) finalidade dos resíduos têxteis (1: fios, 2: tecidos); e (VII) quantidade de resíduo têxtil descartado por período. O Quadro 8 apresenta uma síntese da realidade das empresas pesquisadas com base nas categorias apresentadas.

A análise apresentada foi realizada com o intuito de verificar se há por parte das empresas uma preocupação a respeito do benefício ao meio ambiente com relação à água, energia (abordado no item I) e, sobretudo aos resíduos sólidos têxteis (abordados nos demais itens). 
Quadro 8 - Síntese da realidade das indústrias pesquisadas em relação às categoria conceituais que emergiam na análise de dados coletados em 2016 e 2017.

Quadro 8 - Síntese da realidade das indústrias pesquisadas em relação às categorias conceituais que emergiram na analise de dados coletados em 2016 e 2017

\begin{tabular}{|c|c|c|c|c|c|c|c|}
\hline entrevistas & $\begin{array}{l}\text { 1- beneficio ao meio ambiente } \\
1 \text { água } \\
2 \text { energia } \\
3 \text { residuo têxtil }\end{array}$ & II- matéria-prima principal & $\begin{array}{l}\text { III- quantidade de residuo } \\
\text { têxtil por setor }\end{array}$ & $\begin{array}{l}\text { IV-residuos separados } \\
\text { por tipo }\end{array}$ & V- recipiente de coleta & $\begin{array}{l}\text { VI- finalidade dos } \\
\text { residuos têxteis } \\
1 \text { fios } \\
2 \text { tecidos }\end{array}$ & $\begin{array}{l}\text { VII- quantidade de } \\
\text { residuo textil descartado } \\
\text { /periodo }\end{array}$ \\
\hline empresa A & $\begin{array}{l}1 \text { sem informaçāo } \\
2 \text { sem registro } \\
3 \text { faz doacăa para o mosteiro da cidade } \\
3 \text { faz reutilizaçāo interna } \\
3 \text { aparas vende para reciclagem }\end{array}$ & $\begin{array}{l}96 \% \text { Viscose } \\
4 \% \text { Elastano } \\
\text { 90\% Acrilico } \\
\text { 10\% Poliamida }\end{array}$ & sem registro & sim, separados & sacos plásticos de 80 litros & $\begin{array}{l}1 \text { doação para mosteiro } \\
\text { com frequência } \\
\text { 2doacaáo para o mosteiro } \\
\text { com frequência } \\
2 \text { sobras de aparas } \\
\text { vendidas para setor de } \\
\text { reciclagem }\end{array}$ & sem registro \\
\hline empresa B & $\begin{array}{l}1 \text { sem informaçāo } \\
2 \text { usa lâmpada led } \\
3 \text { faz doaçāo para artesanato } \\
3 \text { armazena para futuros adaptaçōes } \\
3 \text { tem etiqueta doar após uso } \\
3 \text { vende aparas para reciclagem }\end{array}$ & $\begin{array}{l}\text { 85\% Acrilico } \\
15 \% \text { Poliamida }\end{array}$ & sem registro & sim, separados & caixa de fios & $\begin{array}{l}1 \text { utiliza para separação } \\
2 \text { doaçáa eventual para } \\
\text { artesanato } \\
2 \text { sobras de aparas } \\
\text { vendidas para setor de } \\
\text { reciclagem }\end{array}$ & sem registro \\
\hline empresa C & $\begin{array}{l}1 \text { sem informação } \\
2 \text { sem informaçăo } \\
3 \text { vende para reciclagem }\end{array}$ & $\begin{array}{l}75 \% \text { Acrilico } \\
25 \% \text { Poliamida } \\
\text { e } \\
90 \% \text { Acrilico } \\
10 \% \text { Poliamida }\end{array}$ & sem registro & sim, separados & sacos plásticos de 80 litros & $\begin{array}{l}1 \text { utilização interna em } \\
\text { peças para coleção } \\
\text { diferenciada } \\
2 \text { sobras do corte e aparas } \\
\text { vendidas para setor de } \\
\text { reciclagem }\end{array}$ & $\begin{array}{l}200 / \mathrm{kg} \text { por semana no } \\
\text { periodo de janeiro a junho }\end{array}$ \\
\hline empresa D & $\begin{array}{l}1 \text { sem informação } \\
2 \text { sem informação } \\
3 \text { vende para reciclagem } \\
3 \text { reutilização interna } \\
3 \text { doaçăo }\end{array}$ & $\begin{array}{l}\text { 50\% Acrílico } \\
50 \% \text { Viscose }\end{array}$ & sem registro & sim, separados & sacos plásticos de 80 litros & $\begin{array}{l}1 \text { reutilizaçăo interna } \\
2 \text { residuos do setor do } \\
\text { corte são vendidos para } \\
\text { reciclagem } \\
2 \text { residuos maiores sāo } \\
\text { doados } \\
2 \text { reutilizaçāo }\end{array}$ & $\begin{array}{l}\text { saco de } 51 / \mathrm{kg} \\
\text { sem registro quantidade de } \\
\text { sacos na semana }\end{array}$ \\
\hline empresa $\mathrm{E}$ & $\begin{array}{l}1 \text { torneira com temporizadores } \\
2 \text { lâmpada led } \\
3 \text { aparas vende para reciclagem }\end{array}$ & 100\% Acrilico & sem registro & sim, separados & sacos plásticos de 80 litros & $\begin{array}{l}1 \text { reutilizaçăo } \\
2 \text { aparas vendidas para } \\
\text { setor de reciclagem }\end{array}$ & 200/kg mês \\
\hline empresa F & $\begin{array}{l}1 \text { água da caldeira é reutilizada para limpeza dos } \\
\text { setores } \\
2 \text { sem registro } \\
3 \text { faz doaçăo } \\
3 \text { faz reutilização interna } \\
3 \text { doaçăo dos resíduos }\end{array}$ & $\begin{array}{l}100 \% \text { Acrilico } \\
\text { verăo } \\
\text { e } \\
100 \% \text { Acrilico } \\
\text { inverno }\end{array}$ & $\begin{array}{l}8 \text { sacos de } 80 \text { litros na } \\
\text { semana contendo resíduos } \\
\text { do corte e costura }\end{array}$ & sim, separados & sacos plásticos de 80 litros & $\begin{array}{l}1 \text { utilizaçăo interna para } \\
\text { acessórios diferenciados } \\
2 \text { doaçăo para artesanato }\end{array}$ & $\begin{array}{l}8 \text { sacos de 8olitros na } \\
\text { semana }\end{array}$ \\
\hline
\end{tabular}

Fonte: elaborado pela autora 
Com relação à conservação de água, com base em dados verificados nos depoimentos, que apenas duas organizações procuraram mudanças de equipamentos ou de ações benéficas que auxiliem na redução do consumo de água. Pode-se entender que o número de empresas se faz reduzido, pois segundo Carvalhal (2016) não há um encorajamento para que se tenha um estilo de vida que preserve o planeta. Porém, o autor destaca que, tanto as pessoas quanto a moda, estão diretamente ligados a questões ambientais.

Conforme analisado no Quadro 8 pode-se observar que quatro das seis empresas pesquisadas relataram não possuírem nenhuma ação que colabore com a pratica de redução de água e energia, porém se mostram conscientes com relação a redução deste consumo.

Nesse sentido, não foram encontrados registros relacionados a economia de água nas empresas $A, B, C$ e D embora a empresa $B$ faça parte dos respondentes que não possuem realizações, declara ter intenções futuras com a questão de economia de água. Assim, pretende realizar modificações na infraestrutura da sua empresa, com intuito de viabilizar a reutilização da água da chuva. A empresa B ressalta ser necessário desenvolver estudos ambientais e econômicos, com relação à mudança da estrutura da empresa para verificação destas possiblidades.

Para Dias (2014) a gestão integrada da água utilizada também é uma forma de ecoeficiência que pode trazer benefícios. A empresa $F$ realiza um direcionamento específico com relação à reutilização de água (uso interno), relatando que fazem uso da água da caldeira rotineiramente para a higienização dos banheiros e outros setores. Deste modo, a empresa $F$ acredita contribuir para um benefício com relação à redução do consumo de água. Já a empresa $\mathrm{E}$, acredita estar economizando, pois faz uso de torneiras com temporizadores.

Observou-se in loco também que todas as seis empresas pesquisadas não possuem um setor para beneficiamento, para a realização de tingimento e práticas de finalizações, como lavagens e estampas, pois são todas realizadas de modo terceirizado. Assim, não sendo possível obter informações sobre consumo e como transcorrem as ações voltadas para o uso da água.

Salcedo (2014) assevera que a problemática na indústria têxtil quanto a água não é apenas a quantidade de seu consumo, tem a ver também com o tratamento realizado. 
Assim, pode-se perceber que questões ambientais estão inseridas no consciente das pessoas, porém a mudança é lenta e carece de uma combinação de fatores importantes, dentre eles: investimento de infraestrutura, profissional especializado para realização e manutenção de equipamentos, para que isto seja uma somatória ao setor têxtil produtivo.

Com relação ao consumo de energia foi identificado que a empresa B e E fazem uso de iluminação com lâmpadas LED no setor de confecção. Com essas lâmpadas alegam alcançar uma iluminação satisfatória para a sua produção e relatam uma importante economia no consumo, se comparadas com a iluminação anterior em que eram usadas lâmpadas frias. Ainda a empresa $B$, ressalta sua satisfação com esta mudança, declarando que pretende futuramente usar energia fotovoltaica.

Com esse relato, a empresa B demonstra o interesse em fazer alterações para uma iluminação mais sustentável (como por exemplo, realizar adaptações com energia solar, a serem planejadas de que forma seriam inseridas), para se beneficiar e contribuir com as questões ambientais.

As outras quatro empresas ( $A, C, D$ e $F)$ quando questionadas a respeito da economia de energia não apresentam registros. A empresa " $F$ " relata que no momento não desenvolve nenhuma ação com relação à conservação do consumo de energia. Contudo, de acordo com Carvalhal (2016) para a economia de energia pode-se considerar a criação de horários alternativos de trabalho de acordo com a época do ano, a inserção de espaços com iluminação natural, a utilização de lâmpadas mais econômicas ou até mesmo a alteração de processos produtivos. Sendo assim, ainda na Empresa F, pode-se perceber que a área da empresa é grande e possui características mais antigas, apresentando muitas janelas com uma claridade natural reduzindo o número de lâmpadas no setor de corte e costura.

Em relação à maquinaria do setor de acabamentos nota-se que nos relatos das empresas não foram citados dados específicos sobre o funcionamento das máquinas que apresentem alguma adaptação para economia de energia. Para Salcedo (2014) um dos desafios da indústria têxtil na minimização do consumo de energia é no setor produtivo. Porém verifica-se que a indústria de maquinaria de tecimento se encontra em evolução buscando a redução do consumo de energia (vide Apêndice A). 
Todas as seis empresas pesquisadas mostraram ações com relação ao resíduo têxtil, cada empresa realiza de acordo com suas produções e possibilidades, contribuindo de maneiras diferentes em beneficio ao meio ambiente. Deste modo, encontraram-se evidências de destinação para o resíduo sólido têxtil, sendo classificado como: doações, reutilização interna e venda para o setor de reciclagem.

Assim, pode-se constatar nos relatos que quatro empresas ( $A, B, D$ e $F$ ) realizam doações diferenciadas. $A$ Empresa $A$ realiza com frequência doações dos tecidos para o mosteiro da cidade (vide Apêndice B) e justifica que faz esta ação por acreditar em contribuir para um aproveitamento mais direcionado, porém não possuem um controle do peso da quantidade do que doam, realizam esta ação somente no final de cada coleção.

Por outro lado, à doação encontrada no relado da Empresa B é praticada esporadicamente e direcionada para instituições que realizam artesanato. $O$ proprietário justifica que tem o costume de guardar muito tecido, que por algum motivo não teve uso, pensando em usufruir futuramente de alguma maneira. Ele deixa claro que tem um apego muito grande quanto a estes materiais, por acreditar que podem ser utilizados de muitas maneiras para desenvolvimento de acessórios, como por exemplo: bolsas, carteiras, capas para livros, cadernos, tapetes para casa. Esses produtos poderiam ser comercializados em seu próprio negócio. O proprietário da Empresa B ainda informa que tem muitas ideias a serem exploradas, testadas e realizadas, contudo ainda é um projeto que não viabilizou na prática, pois exige uma estrutura a ser montada, dependendo de pessoas capacitadas com o conhecimento e habilidade nas técnicas de costura, acabamento e manufatura de novos produtos com a matéria primas dos processos produtivos de malharia.

Nos relatos obtidos das Empresas $\mathrm{D}$ e $\mathrm{F}$ as doações são feitas para seus próprios funcionários que desenvolvem peças diferenciadas tendo como foco principal produtos artesanais. A Empresa $F$, além dessa ação, também realiza doações para ONGs que utilizam esses resíduos para a elaboração de roupas para boneca e roupas para cachorro. Essas constatações reforçam a visão de Bonduki e Pimentel (2012) os quais afirmam que o setor têxtil brasileiro e de confecção é encontrado em todo território nacional promovendo desenvolvimento econômico e gerando empregos diretos ou indiretos. 
Quanto à reutilização interna praticada com os resíduos têxteis encontraram se três empresas: A, D, e F. Essas empresas realizam esta ação normalmente em tecidos que apresentam algum tipo de defeito. Para Cardoso (2008) as reações do designer brasileiro são as mais variadas quando se trata dos desafios ambientais, tem-se visto nos últimos anos o reaproveitamento de materiais descartados bem como a gestão racional de processos industriais e construtivos.

A reutilização interna realizada pela Empresa $A$ é direcionada a elaboração de acessórios como echarpes e golas. A Empresa D, na tentativa de amenizar os desperdícios relata realizar realizando readaptações nos modelos quando esses sofrem defeitos como, por exemplo, a transformação de um vestido em blusa, conforme a Figura 15.

Figura 15 - Vestido listrado (a) adaptado para blusa (b)

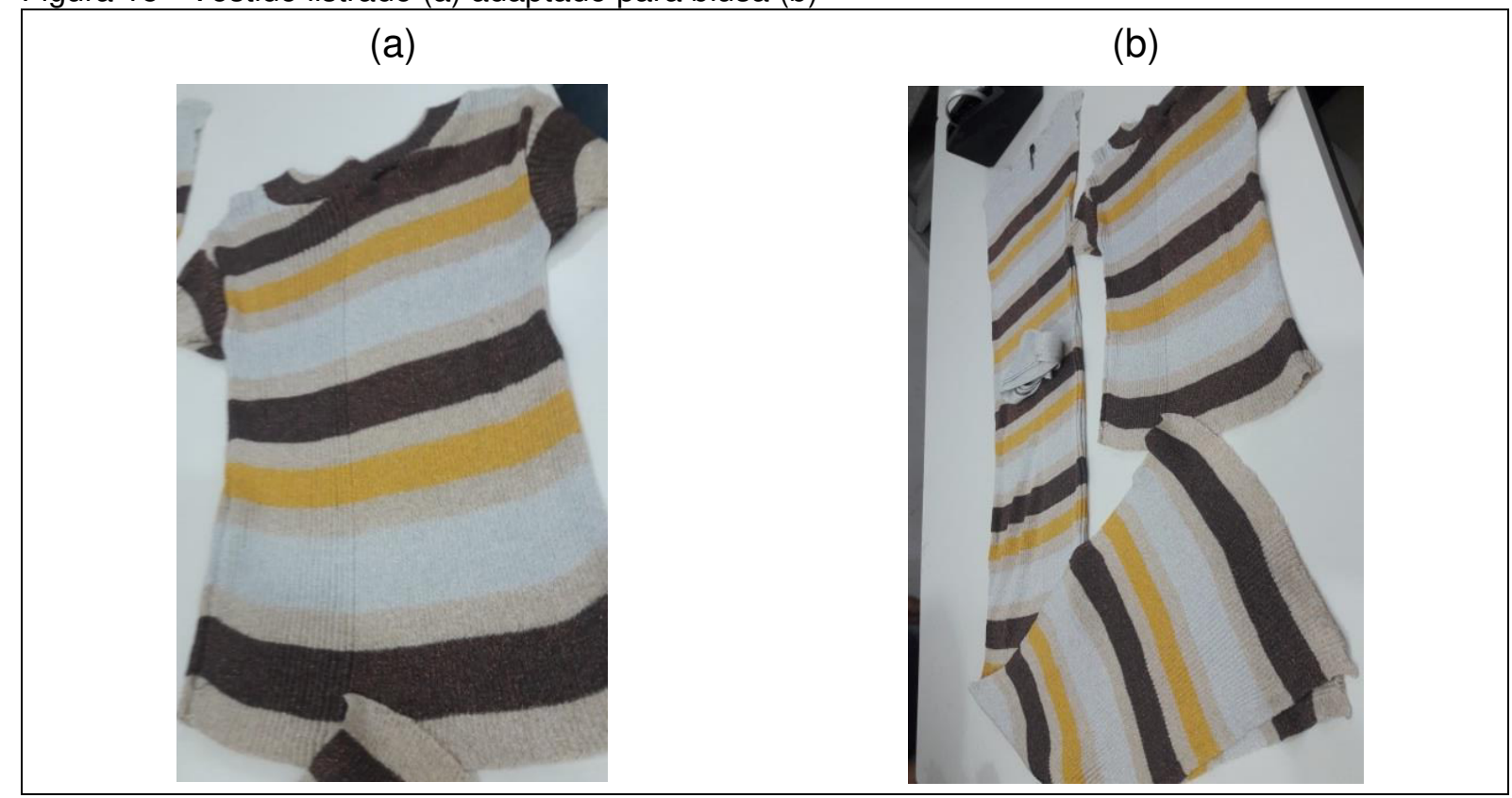

Fonte: elaborado pela autora ${ }^{2}$.

O vestido era uma peça da coleção, teve que ser reinserido como um novo modelo, pois devido a um imprevisto durante o processo de tecimento foi necessária intervenção imediata, para que não se perdesse uma grande quantidade de peças com o mesmo defeito. Desta forma, o que seria inicialmente um vestido foi reestruturado para blusa, aproveitando o máximo possível do que seria descartado.

Já a Empresa $\mathrm{F}$ relata que devido à ocorrência de defeitos na produção, muitas peças são remodeladas recebendo uma etiqueta especial, sendo comercializadas

\footnotetext{
${ }^{2}$ Material fornecido pela Empresa D em entrevista realizada pela autora no ano de 2016.
} 
posteriormente a preços promocionais. Explica que as partes de tecidos com defeito são armazenadas em caixas de plástico, para serem retrabalhadas posteriormente ao período de demanda.

Percebe-se então, que há direcionamentos internos, para tentar aproveitar ao máximo, evitando descarte dos tecidos ou peças que poderiam ser perdidas no processo de fabricação. Gwilt (2014) afirma que muitos designers, baseando-se em reciclagem, utilizam de resíduos da confecção e sobra de fios e outros materiais de forma bem-sucedida, a fim de gerar novas peças.

Segundo Leite (2009), a partir do momento em que há um controle em que os bens são dispensados de maneira ordenada para não causar danos ao meio ambiente $\mathrm{e}$ não afetar a sociedade, a esse processo denomina-se disposição final segura. Encontrou-se registro de disposição final segura nas Empresas A, B, C, D e E, as quais realizam rotineiramente a venda para a reciclagem. Em contrapartida, a empresa $F$ discorre que não realiza a venda de seus resíduos, porém todos estão incluídos nas doações. Desta maneira pode-se verificar que todas as empresas dão a destinação correta quando questionadas a respeito dos resíduos têxteis.

Para Braungart e Mcdonough (2013) a maioria dos materiais da produção têxtil são provenientes de base petroquímicas. Sissons (2012) defende que a seleção de fios é uma fase muito importante, pois impactam em muitos fatores, dentre eles a qualidade da matéria-prima e sua adequação para o produto final. Desta maneira as empresas foram questionadas em relação a gestão dos resíduos, gerando as categorias II-VII, apresentadas inicialmente neste capítulo.

Na categoria II (matéria-prima principal) verificou-se que todas as seis empresas pesquisadas utilizam de fibra acrílica em suas produções, porém algumas usam composições mistas. Para Fletcher e Grose (2011) o sistema ecológico e social pode ser afetado por qualquer tipo de material, de maneira que para cada tipo de material utilizado e fibra que este é composto há diferenças com relação ao impacto causado. Ainda as autoras afirmam que desata maneira é gerado um complexo conjunto de contrapontos que estão diretamente ligados a questões voltadas a sustentabilidade.

Assim, as Empresas A, B, e C utilizam o acrílico com a poliamida, onde conferem as malhas um toque e caimento diferenciado. Já a Empresa $D$ destaca-se como a única a utilizar em sua fabricação acrílico e viscose, enquanto as Empresas E e F consomem 
fios geralmente com composições de acrílico, tanto para verão como para inverno. Assim, as Empresas A, B, e C utilizam o acrílico com a poliamida, a Empresa D destaca-se como a única a utilizar em sua fabricação acrílico e viscose, enquanto as Empresas $\mathrm{E}$ e $\mathrm{F}$ consomem fios geralmente com composições de acrílico, tanto para verão como para inverno.

Com relação à categoria III (quantidade de resíduo têxtil por setor), nas declarações foram registradas que cinco empresas ( $A, B, C, D$ e E) não possuem informações sobre esta questão, pois alegam não terem ideia da quantidade por setor. No entanto, a Empresa $\mathrm{F}$ destaca-se como sendo a única que relata esta informação. Embora não tenha registro do peso em kilos, a empresa tem o conhecimento que descarta 8 sacos de 80 litros de resíduos têxteis por semana, gerados nos setores de corte e de costura. Um dado relevante que pode ser percebido em todas as seis empresas pesquisadas, foi o fato de separarem todos os resíduos por tipo, assim cada material tem seu pacote específico como o de têxtil, o de papelão e o de plástico, gerando a categoria IV (resíduos separados por tipo).

A respeito da categoria $V$ (recipiente de coleta), constatou-se que das seis empresas entrevistadas cinco relatam usar sacos plásticos de 80 litros devido a praticidade. São essas, as Empresas A, C, D, E e F. Apenas a empresa B afirma utilizar caixa dos próprios fios para estes fins.

Manzini e Vezzoli (2011) defendem que a maneira de manufaturar um produto bem como utilizar ou descartar o mesmo interferem no peso que este tem com relação aos impactos ambientais. Nesse sentido, a categoria VI (finalidade dos resíduos têxteis) foi subdividida entre modalidade (1) fios e (2) tecidos, de maneira a facilitar as evidencias encontradas.

Na modalidade (1) fios, encontraram-se duas ações, sendo a primeira voltada para 0 aproveitamento da matéria-prima, onde as Empresas B, C, D, E e F realizam de alguma maneira uma reutilização interna destes fios. Apenas a Empresa $A$ faz doações para o mosteiro da cidade, pois alega que seu público, seu tipo de produto e suas maquinas não se adequam a uma reutilização de matéria-prima. 
Figura 16 - Casaco produzido com a mistura de fios que seriam descartados, destaque ampliado da textura da peça no lado avesso.

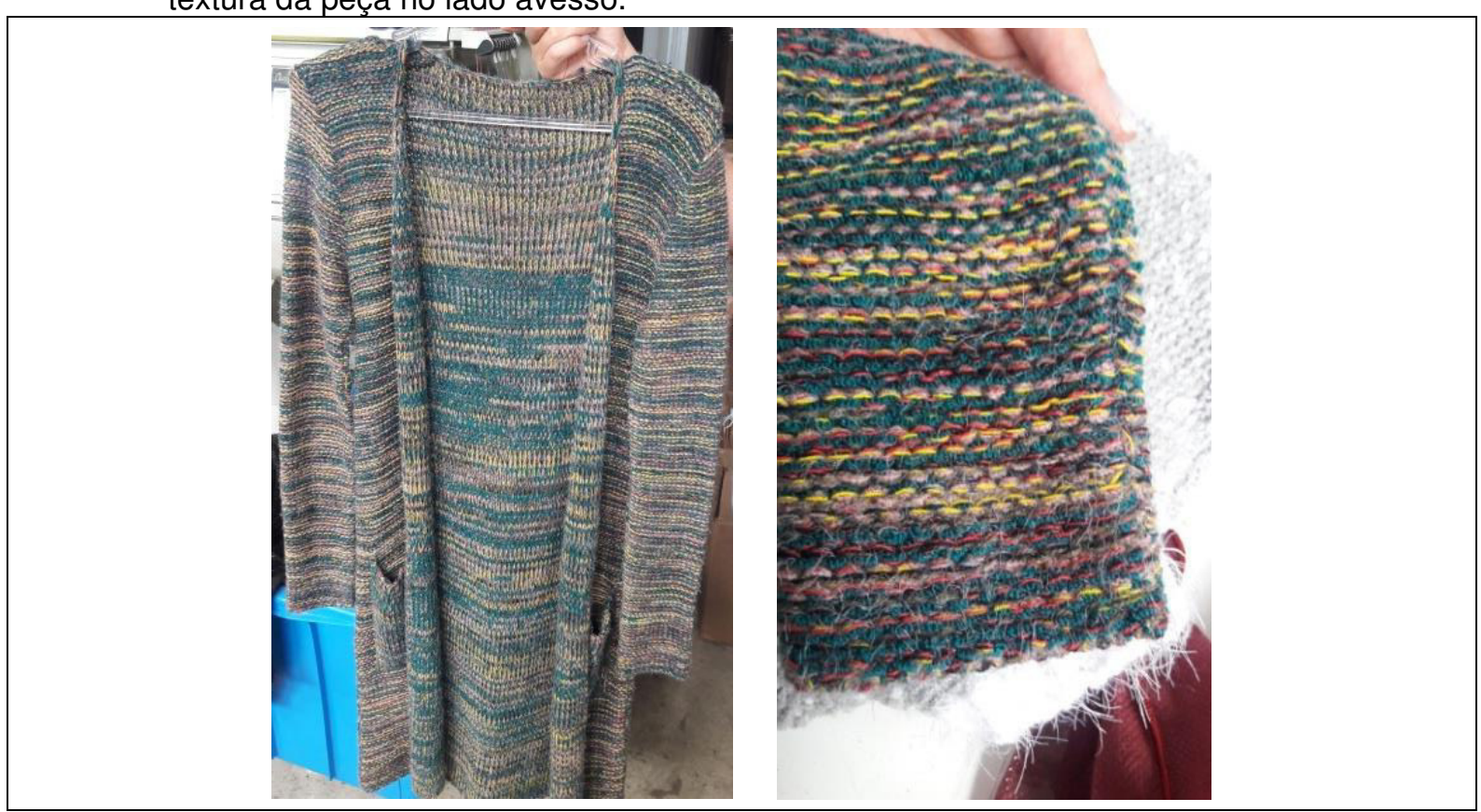

Fonte: elaborado pela autora ${ }^{3}$.

Pode ser observado na Figura 16 uma peça produzida a partir do aproveitamento de matérias-primas fios elaborando um modelo especifico na empresa $D$.

$\mathrm{Na}$ modalidade (2) tecidos, denotam-se que as Empresas A, B, D e F doam de diversos modos seus tecidos para serem reaproveitados de alguma maneira por outras pessoas, porém estas empresas ainda realizam a venda para o setor de reciclagem de todo resíduo têxtil que não foi direcionado anteriormente. Entretanto, as Empresa $\mathrm{C}$ e $\mathrm{E}$ relatam realizar apenas a venda para o setor de reciclagem (vide Apêndice C).

A respeito da categoria VII (quantidade de resíduo têxtil descartado por período), o processo de descarte ocorre de maneira diferenciada entre as empresas. A Empresa A e B não possuem estes dados, porém as Empresa C, D, E e F possuem alguns dados estimados, no qual a Empresa $C$ relata descartar 200kg por semana no período de janeiro a junho.

A Empresa D forneceu uma quantidade de um pacote de 80 litros que pesava $51 \mathrm{~kg}$ (Figura 17), porém discorre que a quantidade de sacos na semana varia muito de acordo com o que estão produzindo. Já Empresa E descarta 200/kg no mês. E por fim a Empresa F discorre que descarta 8 sacos de 80 litros na semana.

\footnotetext{
${ }^{3}$ Material fornecido pela Empresa D em entrevista realizada pela autora no ano de 2016.
} 
Figura 17 - Pesagem do pacote, pacote contendo resíduos têxteis de malharia.

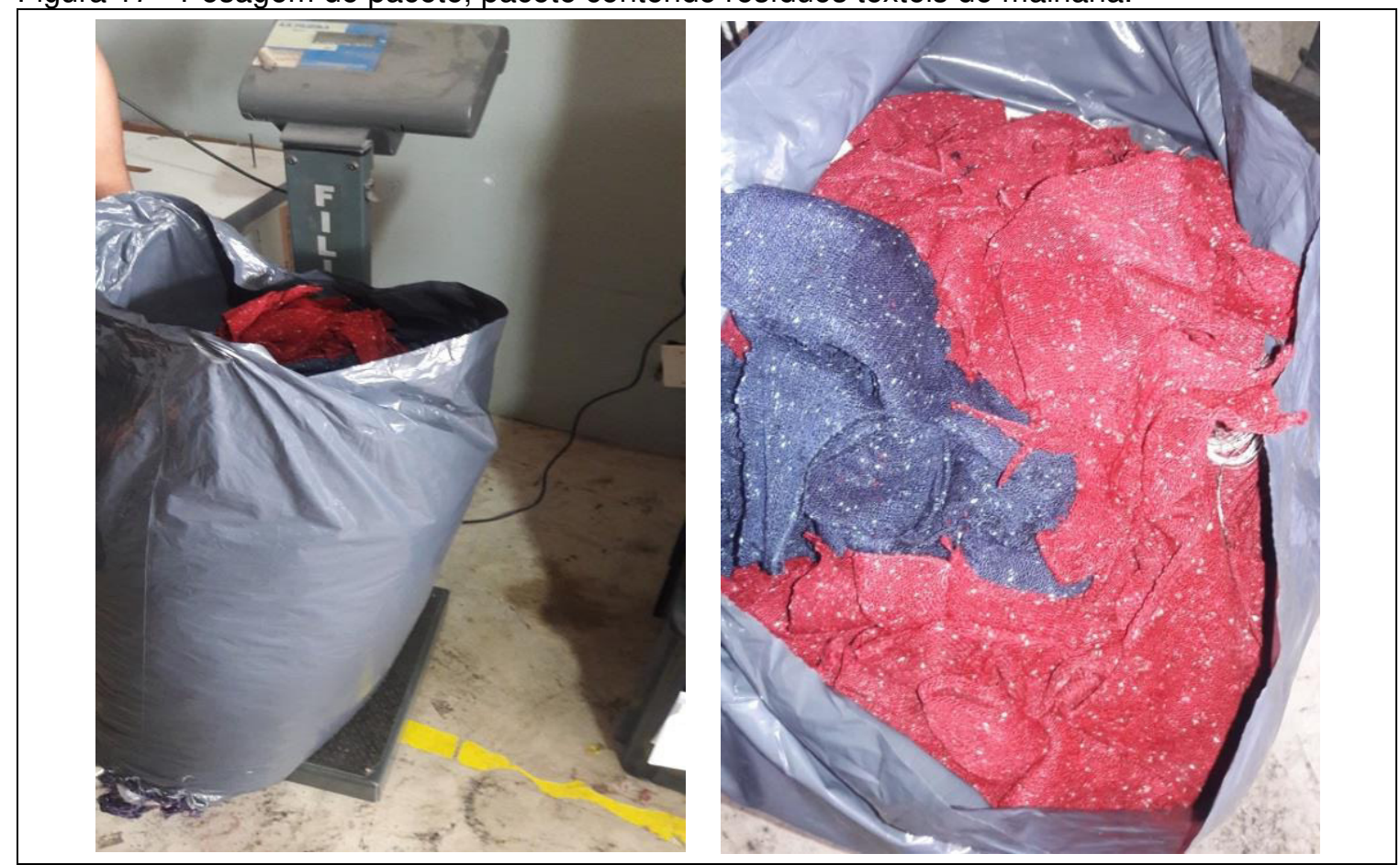

Fonte: elaborado pela autora ${ }^{4}$.

De modo geral, o Quadro 8, trouxe informações que mostram o posicionamento das empresas. Com relação a categoria III (quantidade de resíduo têxtil descartado por período) pode-se perceber não haver ainda uma padronização do levantamento dos dados por parte das empresas. Mesmo assim foi possível detectar alguns dados, entretanto não foi viável realizar um comparativo destas quantidades, pois algumas se utilizam de dados genéricos como quantidade de caixas e sacos e as que possuem o peso não sabem quantos pacotes e qual o período.

Porém, o Quadro 8 mostrou como são tratados os resíduos sólidos têxteis, indicou reutilizações e doações, bem como categorias sem registro, enfim contribuiu de forma a identificar um segmento que ainda necessita de muitas pesquisas e lacunas a serem estudadas.

\footnotetext{
${ }^{4}$ Material fornecido pela Empresa "D" em entrevista realizada pela autora no ano de 2017.
} 


\subsection{ANÁLISE COM RELAÇÃO AS EMPRESAS E A GESTÃO AMBIENTAL}

Para melhor entender as indicações de incidência de ações ambientais nas seis empresas pesquisadas analisou-se as formas de atuação em gestão empresarial, baseando-se em Barbieri (2007). Com base no Quadro 9, apresentam-se três abordagens para análise, as quais são divididas em ações. Inicialmente, tem-se o controle de poluição em ações de tecnologia de remediação e tecnologia de controle no final do processo. Em seguida, a abordagem de integração preventiva segue em cinco ações, são elas: redução na fonte, reuso e reciclagem, recuperação energética, tratamento e disposição final. E, por fim, para abordagem integração estratégica duas ações foram usadas: ciclo de vida e perspectivas para o futuro. Analise dessas abordagens é feita por meio de três categorias, são elas: (1) água, (2) energia e (3) resíduo sólido têxtil.

Pode-se notar que, com relação a abordagem controle da poluição com ações em tecnologia de remediação, nenhuma das empresas apresentaram registro, seja na categoria água, energia bem como resíduo sólido têxtil. Ainda dentro desta mesma abordagem, porém direcionada a análise para tecnologia de controle no final do processo, nota-se que três empresas aparecem na categoria resíduo sólido têxtil. As Empresas C, D e F fazem o controle utilizando o fio no final da produção, reinserindo a matéria-prima no processo produtivo de alguma maneira.

Já na abordagem integração preventiva com relação a ações de redução na fonte encontrou-se somente a Empresa $E$ na categoria água, em que relata fazer uso de torneiras com temporizadores em sua empresa. Já na categoria energia, pode-se identificar duas empresas que relatem fazer uso em seus locais de trabalho de iluminação com lâmpadas Led. 
Quadro 9 - Quadro geral de formas de atuação em gestão ambiental empresarial, segundo modelo de Barbieri (2006) indicando a incidência de ações ambientalistas nas seis empresas pesquisadas.

\begin{tabular}{|c|c|c|c|c|c|c|c|c|c|c|c|c|c|c|c|c|c|c|c|}
\hline \multirow{3}{*}{ ABORDAGEM } & \multirow{3}{*}{ ações } & \multicolumn{6}{|c|}{ 1: ÁGUA } & \multicolumn{6}{|c|}{ 2: ENERGIA } & \multicolumn{6}{|c|}{ 3: RESÍDUO SÓLIDO TÊXTIL } \\
\hline & & \multicolumn{6}{|c|}{ Empresas } & \multicolumn{6}{|c|}{ Empresas } & \multicolumn{6}{|c|}{ Empresas } \\
\hline & & $A$ & $B$ & $\mathrm{C}$ & $\mathrm{D}$ & $E$ & $\mathrm{~F}$ & A & B & C & D & $\mathrm{E}$ & $\mathrm{F}$ & A & B & C & D & $E$ & $\mathrm{~F}$ \\
\hline \multirow{2}{*}{$\begin{array}{l}\text { Controle da } \\
\text { poluição }\end{array}$} & $\begin{array}{l}\text { tecnologia de } \\
\text { remediação }\end{array}$ & & & & & & & & & & & & & & & & & & \\
\hline & $\begin{array}{l}\text { tecnologia de } \\
\text { controle no final } \\
\text { do processo } 5\end{array}$ & & & & & & & & & & & & & & & - & - & & - \\
\hline \multirow{5}{*}{$\begin{array}{l}\text { Integração } \\
\text { preventiva }\end{array}$} & redução na fonte & & & & & - & & & - & & & • & & & - & & & - & \\
\hline & $\begin{array}{l}\text { reuso e } \\
\text { reciclagem }\end{array}$ & & & & & & - & & & & & & & - & & & - & & - \\
\hline & $\begin{array}{l}\text { recuperação } \\
\text { energética }\end{array}$ & & & & & & & & & & & & & & & & & & \\
\hline & tratamento & & & & & & & & & & & & & & & & & & \\
\hline & disposição final & & & & & & & & & & & & & • & - & $\bullet$ & - & - & - \\
\hline \multirow{2}{*}{$\begin{array}{l}\text { Integração } \\
\text { estratégica }\end{array}$} & ciclo de vida & & & & & & & & & & & & & & - & & & & \\
\hline & $\begin{array}{l}\text { perspectivas para } \\
\text { o futuro }\end{array}$ & & - & & & & & & - & & & & & & - & & & & \\
\hline
\end{tabular}

Fonte: elaborado pela autora 
$\mathrm{Na}$ categoria resíduo sólido quando se trata da minimização na geração de resíduos apenas as Empresas B e E se enquadram, pois utilizam máquinas que produzem peças com o mínimo de resíduo, em que Ganzer et al. (2012), defende ser possível detectar a implantação de máquinas retilíneas que trabalham com tecnologia de peça pronta, com a finalidade de também aderirem as questões de gestão ambiental, uma vez que este processo pode ser mais demorado, porém é mais vantajoso por não gerar sobras de materiais na concepção da roupa. Para Jones (2005), vestuários concebidos em malharia integral necessitam de menos recursos do que os confeccionados tradicionalmente com corte e costura.

Nesta mesma abordagem, porém analisando reuso e reciclagem, se encontra enquadrado na categoria água, a Empresa F. Esta empresa relata reutilizar a água da caldeira para limpeza dos setores da empresa. Na categoria energia não obteve-se registros. Já na categoria resíduo sólido têxtil, houveram três empresas com ações de reutilizações, sendo estas as Empresas A, D e F. Essas empresas realizam o reuso ou o reaproveitamento de seus resíduos têxteis (tecidos) dentro da própria empresa criando novos acessórios ou realizando modificações em modelos.

Ainda na abordagem integração preventiva nas ações recuperação energética e tratamento não foram encontrados registros seja na água, na energia ou no resíduo. Enquanto que na abordagem disposição final água e energia não tem-se registro, na categoria resíduo sólido pode-se constatar que todas as seis empresas pesquisadas apresentam uma forma de encaminhamento para o resíduo têxtil realizando uma disposição final adequada enviando para o setor de reciclagem.

Quanto a abordagem integração estratégica em ações de ciclo de vida, nas categorias água e energia não obteve-se registros. No entanto, na categoria resíduo sólido a Empresa B se enquadra quando discorre fazer uso de uma etiqueta especial "Doe após o uso" incentivando desta maneira o reuso da roupa. Nesse sentido, para Cardoso (2008) o ciclo de vida do produto deve ser raciocinado pelo design com expansão, levando em consideração um pós-uso que possibilite ampliar de modo indeterminado a vida útil do produto. Barbosa Filho (2009) um dos princípios e objetivos gerais do desenvolvimento de produtos, conduzindo as questões ambientais, é o multiuso. Assim, incentiva-se que um mesmo produto possa ser utilizado por inúmeros usuários. 
Ainda na abordagem de integração estratégica em ações de perspectivas para o futuro, foram encontrados registros apenas na Empresa B em todas as categorias. Para água a empresa tem intenções futuras de fazer uso da água da chuva; na categoria energia, a empresa relata ter intenção de adequar energia fotovoltaica; e na categoria resíduo sólido, pretende aproveitar melhor os resíduos que guarda e transformá-los em acessórios para serem vendidos em sua empresa.

Segundo Matos e Bezerra (2012) opções sustentáveis estão cada vez mais sendo adaptadas pela indústria de moda e vestuário. É possível que empresas realizem o desenvolvimento de acessórios de moda a partir de resíduos têxteis, gerando desta forma lucro e mostrando contribuições éticas e sustentáveis.

De maneira geral, o quadro de formas de atuação em gestão ambiental empresarial pontuou ações dentro de cada abordagem. Vale destacar que a ação "disposição final", encontrada na abordagem integração preventiva, mostrou-se completamente atuante nas seis empresas, as quais cuidam do encaminhamento de seus resíduos sólidos têxteis. Neste sentido, também revelaram preocupações com a tecnologia de controle no final do processo, embora para esta ação somente três empresas foram detectadas.

Em geral, não existem muitos dados, porém todas as malharias revelaram conscientização e preocupação com impactos gerados pelo setor, mesmo não possuindo nenhuma prática no momento. A redução na fonte aparece apenas em duas empresas ( $\mathrm{B}$ e E), porém caracterizam indícios de gestão ambiental encontrados neste polo industrial.

\subsection{ANÁLISE RELACIONADA A APROXIMAÇÃO DA PRODUÇÃO MAIS LIMPA}

O Quadro 10, com base em Senai (2007), mostra uma análise geral das formas de atuação em níveis de oportunidade de Produção mais Limpa nas seis empresas pesquisadas com foco no resíduo sólido têxtil, pois com relação a água e energia não foram encontrados dados suficientes para a realização de uma análise mais profunda. 
Quadro 10 - Analise geral das formas de atuação em níveis de oportunidade de Produção mais Limpa nas seis empresas pesquisadas

\begin{tabular}{|c|c|c|c|c|c|c|}
\hline CATEGORIA & \multicolumn{3}{|c|}{ MINIMIZAÇÁO DE RESÍDUOS E EMISSÓES } & \multicolumn{3}{|c|}{ REUSO DE RESÍDUOS, EFLUENTES E EMISSÖES } \\
\hline Nível & \multicolumn{2}{|c|}{ Nível 1} & Nível 2 & \multicolumn{3}{|c|}{ Nível 3} \\
\hline \multirow[t]{2}{*}{ Processo } & \multicolumn{2}{|c|}{ Redução na fonte } & \multirow[t]{2}{*}{ Reciclagem interna } & \multicolumn{2}{|c|}{ Reciclagem externa } & \multirow[t]{2}{*}{ Ciclos biogênicos } \\
\hline & $\begin{array}{l}\text { Modificação no } \\
\text { produto }\end{array}$ & $\begin{array}{c}\text { Modificação no } \\
\text { processo }\end{array}$ & & Estruturas & Materiais & \\
\hline A & & & $x$ & & $x$ & \\
\hline B & & $x$ & & & $x$ & \\
\hline C & $x$ & & & & $x$ & \\
\hline D & $x$ & & $x$ & & $x$ & \\
\hline E & & $x$ & & & $x$ & \\
\hline $\mathbf{F}$ & $x$ & & $x$ & & $x$ & \\
\hline
\end{tabular}

Fonte: Elaborado pela autora 
O Quadro 10 possui três níveis de divisões, sendo que os dois primeiros (redução na fonte e reciclagem interna, respectivamente) fazem parte do processo de minimização de resíduos e emissões e o terceiro (reciclagem externa e ciclos biogênicos) estão inseridos no reuso de resíduos, efluentes e emissões.

Produção mais Limpa segundo Furtado (2005), é entendida como uma estratégia ambiental que tem como prevenção a aplicação nos processos bem como nos produtos e serviços com o objetivo de reduzir impactos ambientais. Ainda Furtado (2005) defende que a partir do momento que a empresa implanta o modelo de $\mathrm{P}+\mathrm{L}$, é possível que a mesma possa solucionar problemas como a redução de custos e investimentos, a redução do uso de energia, consumo de materiais, e outros.

Alguns dos desafios principais que a indústria têxtil enfrenta a respeito da redução do impacto ambiental, segundo Salcedo (2014) são redução no consumo de água, redução de uso direto ou indireto de energia nos produtos têxteis, e redução na quantidade de resíduos sólidos têxtil.

Nos dados analisados pode-se observar na categoria minimização de resíduos e emissões, que as empresas C, D, e F, se encontram classificadas no nível 1, redução na fonte, em que atuam com modificações no produto, assim utilizando-se de sobras de matéria-prima, como fios. Retornando estes fios ao início do processo para a criação de produtos diferenciados, como peças listradas ou mescladas de modo a utilizar boa parte da matéria-prima investida inicialmente.

Percebe-se neste contexto que as empresas citadas acima possuem uma conscientização e discernimento na utilização de sua matéria prima o que segundo Bastian e Rocco (2009), indica o início da Produção mais Limpa nos processos que acontece geralmente com a aplicação de "bom senso" que é desenvolvida com o tempo até fazer parte de seus conceitos e gestão da administração.

Ainda no nível redução na fonte, porém atuando na modificação do processo, encontram-se as Empresas B e E. Ambas as empresas possuem modificações em tecnologia (máquina de peça pronta) e se assemelham neste processo, pois economizam matéria-prima, mão de obra logo no início da fabricação do produto. Máquinas que possuem tecnologia avançada permitem a fabricação de produtos em grande quantidade, porém com maior qualidade. Elas também permitem a elaboração 
de produtos diversificados com maior valor agregado diminuindo custos e elevando possíveis lucros (SEVEGNANI; SACOMANO, 2008).

Para o nível 2, no processo de reciclagem interna destacam-se as Empresas A, D, e F. As três empresas trabalham com seus próprios tecidos, atribuindo a estes um novo modelo, reciclando dentro da empresa e evitando o descarte. Com isto, asseguram uma rentabilidade de seus investimentos ao mesmo tempo em que oferecem algo diferente.

Salcedo (2014) defende que o processo de fabricação do vestuário gera diversos resíduos sólidos que fazem parte das etapas de produção e vida útil de um produto. O impacto causado ao meio ambiente está cada vez mais ligado aos produtos, bem como máquinas, insumos, processos, formas e métodos de organização do trabalho. Para a categoria reuso de resíduo, efluentes e emissões do nível 3, no processo de reciclagem externa de materiais, todas as seis empresas pesquisadas $(A, B, C, D, E$ e F), se encontram realizando reciclagem externa. Deste modo, pode-se observar in loco que muitos dos materiais são doados ou enviados para reciclagem de maneira a controlarem a disposição final dos resíduos gerados pelo produto que fabricam.

Martins et al. (2014) afirma que desenvolver técnicas novas e eficientes no reaproveitamento de resíduos sólidos têxteis sintéticos gerados na indústria do vestuário é uma necessidade desafiadora, enfrentada nos dias atuais pelas empresas, afim de se manterem competindo nos mercados, que é cada vez mais exigente com relação a produções sustentáveis.

Contudo, denota-se a conexão entre todas as seis empresas estudadas quando se evidência o processo de reciclagem externa, em que mantem-se a disposição final para os resíduos produzidos por estas malharias. 


\section{CONSIDERAÇÕES FINAIS}

Ao responder as subdivisões do problema fundamental da pesquisa, aqui apresentamse os padrões de associações resultantes da investigação. Este estudo objetivou produzir conhecimento para o campo do têxtil e moda, a respeito do estimado impacto ambiental de malharias retilíneas selecionadas no polo têxtil da região de Monte Sião, no Sul de Minas Gerais, quanto à maior ou menor presença de preocupações da "Produção mais Limpa", tendo como foco principal os resíduos sólidos têxteis observando de maneira secundária a redução do uso de água e energia.

A partir do estudo bibliográfico sobre o tema foram desenvolvidos quadros analíticos que puderam auxiliar na verificação de preocupações ambientais. Neste sentido, níveis de oportunidade de $\mathrm{P}+\mathrm{L}$ foram pontuados nas empresas. Em destaque, reciclagem externa se mostra em evidência, pois todas as empresas desenvolvem esta ação e, de maneira geral, executam um gerenciamento de seus resíduos.

Foi possível verificar em todos os quadros analisados que alguns fatores não foram citados pelas empresas, ou ainda não existem ações realizadas para determinadas situações. Contudo, foi possível verificar indicações de oportunidades de gerenciamento ambiental e de Produção mais Limpa que podem abrir caminho para melhoria de gestão ambiental a serem implantados e trabalhados por cada empresa, conforme sua realidade.

Os relatos dos respondentes das seis empresas possibilitaram agregar um entendimento mais amplo sobre a problemática abordada, pois suas experiências trouxeram informações relevantes e de qualidade que revelam aspectos dos subproblemas estudados.

Nesta investigação com relação à redução do consumo de água, percebeu-se que as malharias ainda se encontram distantes de ações de grande impacto. Contudo, ao que diz respeito à redução de recursos como água e energia dentro das empresas, alguns indícios foram relevantes e mostram uma conscientização a esta temática.

Notou-se que a empresa E possui sistema para economia de água e a empresa $\mathrm{F}$ tem um direcionamento para o reuso de água. Verificou-se também que nenhuma das empresas pesquisadas fazia tratamento de água após o uso. Com relação aos 
pigmentos encontrados na cadeia têxtil e que são altamente poluentes, não estão diretamente ligados às malharias, pois fazem parte de trabalhos terceirizados.

Além disto, em relação à redução do consumo de energia, pode se constatar que a minoria das empresas $(B, E)$ possui alguma adequação racional quanto à iluminação do ambiente. Com relação aos equipamentos de última geração que auxiliam na redução do consumo de energia, pode-se verificar que algumas já estão adaptadas. No entanto, no seu processo de produção, com relação a todo maquinário referente à execução do produto, não apresentam ações voltadas para a economia de energia.

Tais preocupações relacionadas à redução do consumo de energia mostram-se mais avançadas no setor têxtil, pois no passado não se detinha muitos recursos tecnológicos que contribuíssem para um resultado. Quanto às perspectivas para o futuro, ainda são de melhoria, visto que a maquinaria cada vez mais tem dados de aprimoramento, buscando se atualizar em eventos e feiras do setor têxtil. Uma das feiras mais importantes ocorre a cada dois anos, onde os malharistas também se atualizam quanto às novidades do mercado e neste sentido procuram ampliar seu conhecimento, juntamente com o processo produtivo de suas empresas.

Com relação à minimização de resíduos sólidos têxteis, alcançada pelo tipo de equipamento utilizado nas malharias, o resultado traz considerações significativas, pois se encontram cada vez mais interessadas em trabalhar com maquinarias mais eficientes. Deste modo, conseguem reduzir consideravelmente a quantidade de resíduo quando se faz uso de máquina compacta, e neste sentido há vantagens em termos de tempo, mão de obra especializada e produto final.

No que concerne à redução da produção de resíduos sólidos têxteis, pode-se entender e constatar que as empresas possuem alguns direcionamentos internos para seus resíduos. Desta maneira, algumas empresas (A, C, D e F) fazem uso de seus próprios materiais excedentes, vinculando-os a uma produção específica e determinada. As demais malharias ( $B$ e $E$ ) alegam ser mais complexos elaborar propostas com o que está sobrando na fábrica, pois este uso interno compreende gastar muito tempo e ter um funcionário exclusivo e qualificado para o desenvolvimento do produto. Além do mais, requer cálculos e execuções que não estão inclusos na rotina da empresa. 
Considerando todo o panorama, notou-se que as empresas já adotam algumas ações de gerenciamento dos resíduos sólidos têxteis, como por exemplo "tecnologia de controle no final do processo", em que articulam as sobras de matéria-prima reinserindo-as no processo e obtendo novos produtos. Ainda se encontra "redução na fonte" com o auxílio no processo de fabricação com novas tecnologias.

Apesar dos esforços já citados pelas empresas, ainda há quantidade significativa de resíduos sólidos têxteis, principalmente pelo fato de sempre haver um resíduo por menor que este seja, devido às técnicas de produção que se iniciam na tecelagem. Desta forma, as finalidades dadas a estes resíduos sólidos têxteis estão divididas, além do uso interno, entre as doações e o encaminhamento para o setor de reciclagem.

Diante do que foi verificado nas empresas estudadas nota-se que elas ainda estão em um estágio muito inicial com relação as práticas de Produção mais Limpa. Porém, existem ações benéficas analisadas nos quadros da presente pesquisa. De certa forma contribuem com o resultado: a reutilização interna, reciclagem e redução na fonte, pois trazem informações de redução com os resíduos e um direcionamento correto.

Neste contexto, parte destas empresas (A, C, D e F) se mostram aptas a fazer redirecionamento interno dos resíduos, com o intuito de usar ao máximo o material investido. Algumas empresas (A, D e F) também realizam ações voltadas a doações, onde se encontram relatos de que os materiais não teriam mais serventia, e então as doações são frequentes, sendo o restante encaminhado ao setor de reciclagem. $O$ que pode ser sintetizado na Figura 18.

$\mathrm{Na}$ Figura 18 representa de forma sintetizada a entrada da matéria-prima enviada para o processo produtivo têxtil da malharia retilínea, onde serão adotados os tipos de tecimento, sendo distintos conforme o produto da empresa. Deste modo, com a finalização da peça, denota-se que sobram resíduos (fios e tecidos) que, conforme a investigação, podem ter três direções diferentes: (1) a reutilização interna na própria malharia; (2) doações de resíduos gerando um aproveitamento para terceiros e; (3) encaminha-os para o setor de reciclagem. 
Figura 18 - Processo produtivo de malharia retilinea com destinação de seus resíduos textêis.

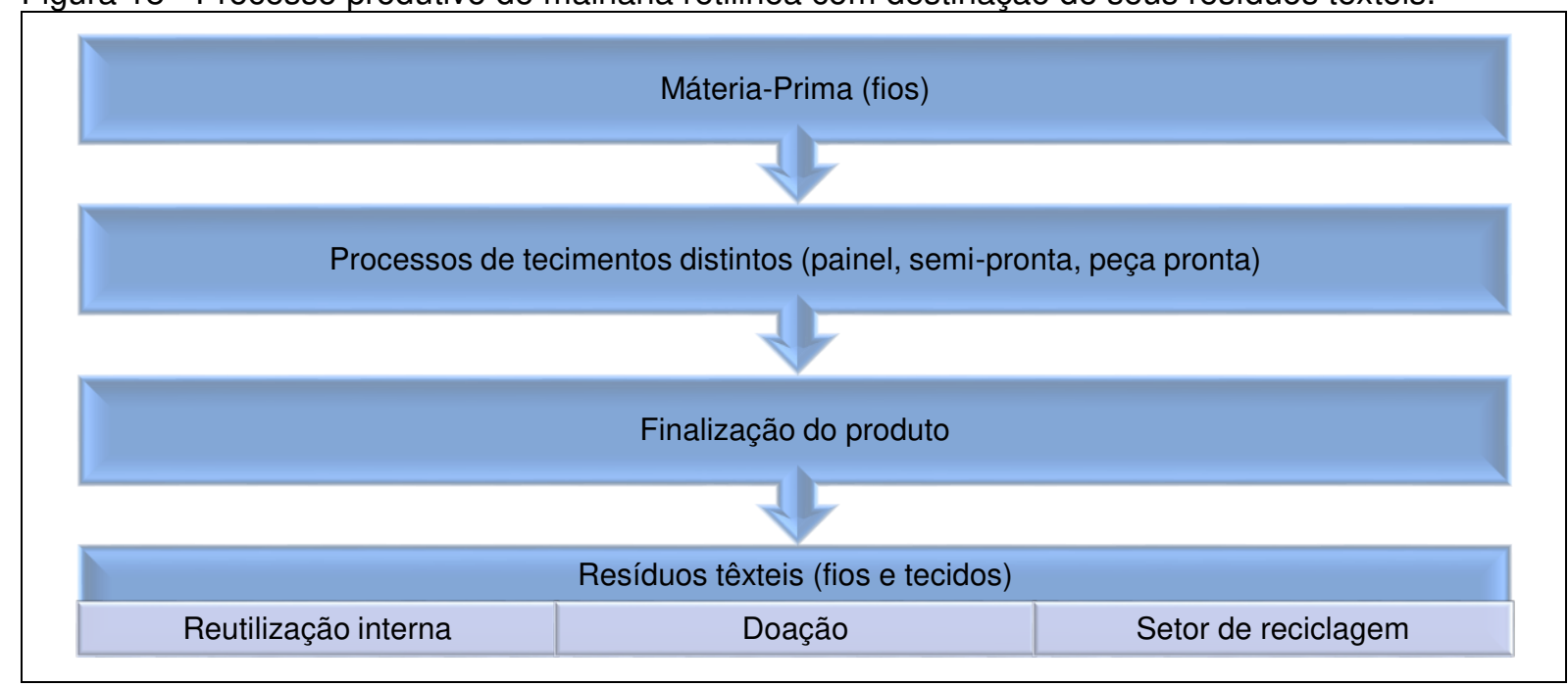

Fonte: elaborado pela autora.

Todas as malharias pesquisadas possuem preocupação com relação aos resíduos sólidos têxteis, e logo um melhor direcionamento, cada malharia pode ter uma ou mais ações dentro do seu desenvolvimento de produto. Logo, é possível que uma mesma malharia realize o reaproveitamento interno e também faça a doação ou venda do que não foi possível aproveitar.

Por fim, os resultados encontrados nesta pesquisa trouxeram algumas indicações sobre a realidade ambiental das malharias na região do Sul de Minas Gerais. Em especial, notou-se maior atenção quanto ao tratamento de resíduo sólido têxtil gerado neste polo. Portanto, é relevante que as malharias entendam que as estratégias de Produção mais Limpa possam ser aplicadas e aprimoradas constantemente. Neste sentido, trata-se de um empenho contínuo que deve ser implantado conforme a realidade vivida em cada empresa em busca da melhoria.

Desta maneira, pode-se verificar que as empresas estão cada vez mais próximas da estratégia de Produção mais Limpa. Neste contexto, foi possível observar como acontece o direcionamento da economia de água e energia e, sobretudo dos resíduos sólidos têxteis em seus processos, onde denotou-se por parte dos entrevistados existir uma consciência de que há ainda melhorias a serem implementadas.

Entretanto, informações a respeito de resíduo têxtil de malharia retilínea é muito restrito, não sendo comum encontrar publicações em artigos científicos, bem como livros ou sites, assim se fazendo necessário entrevistar profissionais do segmento e também desenvolver visitas técnicas em empresas do setor para alcançar dados mais aprofundados. 
Neste contexto, recomenda-se desenvolver um estudo futuro detalhando o assunto, por outro lado tais resultados podem mostrar oportunidades para o polo industrial estudado, pois atendem as necessidades de um publico de moda e se mostram atentos e integrados mesmo que minimamente com as ações de produção mais limpa sendo um avanço e uma contribuição para o setor têxtil.

Observa-se que futuramente análises mais detalhadas possam ser realizadas em relação ao impacto ambiental do setor de malharia, a fim de traçar um quadro comparativo e analisar, de forma continuada, a extensão e a amplitude desta problemática a partir de um maior número de empresas. 


\section{REFERÊNCIAS}

ABIT. Agenda de Prioridades Têxtil e Confecção - 2015/2018. Brasília: Abit, 2014.

ABIT. Indústria Têxtil e de Confecção Brasileira: cenários, desafios, perspectivas, demandas. Brasília: Abit, 2013.

ABIT. Relatório de atividades ABIT 2015. Brasília: Abit, 2015.

ABNT. NBR ISO 14040: Gestão ambiental - Avaliação do ciclo de vida: Princípios e estrutura. Rio de Janeiro: ABNT, 2001.

ACIMS. Notícias. ACIMS. 2016. Disponível em: <http://www.acims.com.br/noticias>. Acesso em: 15 abr. 2016.

ALKAYA, E.; DEMIRER, G. N. Sustainable textile production: a case study from a woven fabric manufacturing mill in Turkey. Journal of Cleaner Production, v. 65, p. 595-603, 2014.

ALMEIDA, A. C. Plano de Gerenciamento de Resíduos Sólidos: instrumento de responsabilidade socioambiental na administração pública. Brasília: Ministério do Meio Ambiente, 2014.

ALMEIDA, M. D.; MOURA, M. Oriented design for sustainable fashion design. In: International Fashion and Design Congress. 1., 2012, Guimarães. Anais... Guimarães: CIMODE, 2012.

AMATO NETO, J. Sustentabilidade e produção: teoria e prática para uma gestão sustentável. Cap. 6, p.90-112. São Paulo: Atlas, 2011.

ANACLETO, C. et al. Eco-efficiency and cleaner production: an analysis of publications in four Brazilian journals from the production engineering field. Sistemas \& Gestão, v. 7, n. 3, p. 476-489, 2012.

ANICET, A.; MÉA, L. D.; CAMPOS, M. Design Sustainable. In: Intenational Fashion and Design Congress. 2012, Guimarães. Anais... Guimarães: CIMODE, 2012.

ANICET, A.; RÜTHSCHILLING, E. A. Contextura: processos produtivos sob abordagem Zero Waste. ModaPalavra e-periódico, v. 6, n. 12, p. 18-36, 2013.

ANTONI, R. DE; FOFONKA, L. Impactos Ambientais negativos na Sociedade Contemporânea. Revista Educação Ambiental em Ação, v. 45, n. 12, 2013. Disponível em: <http://www.revistaea.org/artigo.php?idartigo=1557>.

AQUINO, M. S. Apostila de métodos e processo de manufatura de malha I. Natal: Departamento de Engenharia Têxtil, Universidade Federal do Rio Grande do Norte, 2008.

AQUINO, M. S. Fundamentos e aplicações da malharia. Textília, v. 85, p. 22-38, 2012. Disponível em: <http://www.textilia.net/arquivo/ 
revistas_digitais/revista_textilia/ed85/textilia85.html>

BARBIERI, J. C. Gestão ambiental empresarial: conceitos, modelos e instrumentos. 2. ed. São Paulo: Saraiva, 2007.

BARBOSA FILHO, A. N. Projeto e desenvolvimento de produtos. São Paulo: Atlas, 2009.

BASTIAN, E. Y. O.; ROCCO, J. L. S. Guia técnico ambiental da indústria têxtil. São Paulo: CETESB/SINDITÊXTIL, 2009.

BERLIM, L. Moda e Sustentabilidade: uma reflexão necessária. São Paulo: Estação das Letras, 2012.

BERLIN, L. G. A Indústria têxtil brasileira e suas adequações na implementação do desenvolvimento sustentável. ModaPalavra e-periódico, v. 7, n. 13, p. 15-45, 2014.

BEZZERA, F. D. Análise retrospectiva e prospectiva do setor têxtil no brasil e no nordeste. Informe Macroeconomia, Indústria e Serviços, v. 8, n. 2, 2014.

BONDUKI, A.; PIMENTEL, F. V. Setor têxtil e de confecções das matérias-primas ao varejo situação atual, perspectivas e agenda de prioridades. Fortaleza:

SIDITEXTL, 2012.

BRASIL. Política Nacional de Resíduos Sólidos. Lei n. 12.305, de 02 de agosto de 2010. planalto.gov. 2010. Disponível em:

<http://www.planalto.gov.br/ccivil_03/_ato2007-2010/2010/lei//12305.htm>. Acesso em: 30 out. 2010.

BRAUNGART, M.; MCDONOUGH, W. Cradle to cradle: criar e reciclar ilimitadamente. 1. ed. São Paulo: Editora Gustavo Gili, 2013.

BRUYNE, P.; HERMAN, J.; SCHOUTH, M. Dinâmica da pesquisa em ciências sociais: os pólos da prática metodológica. Rio de Janeiro: Francisco Alves, 1977.

CARDOSO, R. Uma introdução à história do design. São Paulo: Edgard Blücher, 2008.

CARVALHAL, A. Moda com proposito manifesto pela grande virada. 1. ed. São Paulo: Paralela, 2016.

CASTIGLIONI, M. Tecnologia tessile III: maglieria e confezione. Bergamo: unibg, 2010. Disponível em: <http://www00.unibg.it/dati/corsi/8616/39370-

Dalmine100227_La filiera.pdf>. Acesso em: 17 maio. 2016.

CEBDS. Guia da Produção mais Limpa: Faça Você Mesmo. Rio de Janeiro: Rede de PmaisL, 2008. Disponível em:

<http://www.gerenciamento.ufba.br/Downloads/guia-da-pmaisl.pdf>. Acesso em: 7 jun. 2016.

CETESB; PNUMA. A Produção mais Limpa e o consumo sustentável na América Latina e Caribe (D. Masera, Ed.). São Paulo: CETESB/PNUMA, 2005. 
CHATAIGNIER, G. Fio a fio: tecidos, moda e linguagem. São Paulo: Estação das Letras, 2006.

CNTL. Implementação de Programas de Produção mais Limpa. Porto Alegre: SENAI-RS/UNIDO/UNEP, 2003.

COBRA, R. L. R. DE B. Proposta de diretrizes para integração entre a Produção Enxuta e Produção mais Limpa. 2015. 144 f.Dissertação (Mestrado em Engenharia de Produção)—Universidade de São Paulo, 2015

COOPER, D. R.; SCHINDLER, P. S. Métodos de Pesquisa em Administração. Porto Alegre: Bookman, 2011.

DIAS, R. Eco-inovação: caminho para o crescimento sustentável. São Paulo: Atlas, 2014.

DORMER, P. Os significados do design moderno: A caminho do século XXI.

Lisboa: Centro Portugues de design, 1995. v. 5

EISENHARDT, K. M. Building theories from case study research. Academy of management review, v. 14, n. 4, p. 532-550, 1989.

EPA. EPA Cleaner Greener Production Programme: Experiences, Impacts and Outcomes for Participant Organisations. Whitaker Institute. Environmental Protection Agency. 2011. Disponível em: <http://whitakerinstitute.ie/project/epacleaner-greener-production-programme-experiences-impacts-outcomes-participantorganisations/>.

FAGUNDES, A. B.; SILVA, M. C.; MELLO, R. Industrial waste management in accordance with National Policy on Solid Waste: a contribution to Micro and Small Enterprises. Espacios, v. 36, n. 1, 2015.

FLETCHER, K. Slow fashion. The Ecologist. 2007. Disponível em: $<$ http://www.theecologist.org/ green_green_living/clothing/269245/slow_fashion.html>. Acesso em: 15 jan. 2011.

FLETCHER, K.; GROSE, L. Moda \& Sustentabilidade: design para mudança. São Paulo: Senac São Paulo, 2011.

FLICK, U. Uma Introdução a pesquisa qualitativa. Porto Alegre: Bookman, 2004. FLORIANO, E. P. Políticas de gestão ambiental. Santa Maria: UFSM-DCF, 2007.

FURTADO, J. S. Sustentabilidade empresarial: guia de práticas econômicas, ambientais e socais. Salvador: NEAMA/CRA, 2005.

FURTADO, J. S.; FURTADO, M. C. Produção limpa. In: Gestão de Operações: A engenharia de produção a serviço da modernização da empresa. 2. ed. São Paulo: ABDR, 1998.

GANZER, P. P. et al. Análise de gestão ambiental em uma indústria de malhas na serra gaúcha. Caxias do Sul: FURG, 2012. Disponível em: 
<http://www.repositorio.furg.br/bitstream/handle/1/5664/389-2007-1-

PB.pdf?sequence=3>. Acesso em: 13 nov. 2014.

GATTI, R. Tessuto tra le due e le tre dimensioni. Strumento per una selezione intuitiva e consapevole dei tessuti tridimensional. 2014. Politecnico di Milano, Scuola del Design, 2014

GIANNETTI, B. F.; ALMEIDA, C. M. V. B. Ecologia industrial: conceitos, ferramentas e aplicações. São Paulo: Edgard Blucher, 2006.

GRUPO HSBC; INSTITUTO 5 ELEMENTOS. Ecoeficiência: sua empresa rumo a um futuro sustentável. São Paulo: Grupo HSBC, 2012. Disponível em: $<$ http://5elementos.org.br/site/wp-

content/uploads/2013/03/PUBLICACAO_2012CartilhaEcoeficienciaHSBC.pdf>.

GWILT, A. Moda sustentável: um guia prático. São Paulo: Gustavo Gili, 2014. IEMI. Relatório Setorial da Industrial Têxtil Brasileira. São Paulo: IEMI, 2013.

JABBOUR, A. B. L. S.; JABBOUR, C. J. C. Gestão ambiental nas organizações. São Paulo: Atlas, 2013.

JACOBI, P. R.; BESEN, G. R. Solid waste management in São Paulo: the challenges of sustainability. Estudos Avançados, v. 25, n. 71, p. 135-158, 2011. JOUR.

JONES, S. J. Fashion designer: manual do estilista. São Paulo: Cosac Naify, 2005.

LEITE, P. R. Logística reversa: meio ambiente e competitividade. São Paulo:

Pearson Prentice Hall, 2009.

LUKEN, R. A. et al. A 20-year retrospective of the National Cleaner Production Centres programme. Journal of Cleaner Production, v. 112, p. 1165-1174, 2016. JOUR.

MACHADO JUNIOR, O.; TORQUETTI, Z. S. C. Guia Técnico Ambiental da Indústria Têxtil. Belo Horizonte: FIEMG, 2014.

MACIEL, C. Produção de lixo no país cresce $29 \%$ em 11 anos, mostra pesquisa. Agência Brasil. 2015. JOUR. Disponível em:

<http://agenciabrasil.ebc.com.br/geral/noticia/2015-07/producao-de-lixo-no-paiscresce-29-em-11-anos-mostra-pesquisa-da-abrelpe>. Acesso em: 19 dez. 2015.

MALDONADO, L. M. O. O futuro da indústria têxtil e de confecções: vestuário de malha. Brasília: MDIC/STI, IEL/NC, 2005.

MALUF, E.; KOLBE, W. Dados técnicos para a indústria têxtil. São Paulo: IPT/ABIT, 2003.

MANZINI, E.; VEZZOLI, C. O desenvolvimento de produtos sustentáveis: os requisitos ambientais dos produtos industriais. 1. ed. São Paulo: Editora da Universidade de São Paulo, 2011. 
MARTINS, S. B. et al. Design and sustainability: Innovation in textile recycling processes for development of new products. In: Fashion and Design International Congress. 2., 2014, Milão. Anais... Milão: CIMODE, 2014.

MATOS, C. H. S.; BEZERRA, G. M. F. Profiting through the waste in the clothing manufacturing industry, a proposal for a sustainable project. In: International Fashion and Design Congress. 1., 2012, Guimarães. Anais... Guimarães: CIMODE, 2012.

MENDES, F. D. Cadeia Têxtil e as Estratégias de Manufatura na Indústria do Vestuário de Moda. 2006. 112 f. Dissertação (Mestrado em Engenharia de Produção)—Universidade Paulista, São Paulo, 2006

MENDES, F. D. Um estudo comparativo entre as manufaturas do vestuário de moda do Brasil e da Índia. 2010. 333 f. Tese (Doutorado em Engenhria de Produção)—Universidade Paulista, São Paulo, 2010

MENDES, F. D.; SACOMANO, J. B.; FUSCO, J. P. A. Rede de empresas: a cadeia têxtil e as estratégias de manufatura na indústria brasileira do vestuário de moda. 1 . ed. São Paulo: Arte \& Ciência, 2010.

MILAN, G. S.; VITTORAZZI, C.; REIS, Z. C. A Redução de Resíduos Têxteis e de Impactos Ambientais: Um Estudo Desenvolvido em uma Indústria de Confecções do Vestuário. In: Seminário de Administração (SemeAd). 13., 2010, São Paulo. Anais... São Paulo: 2010.

MORELLI, G. Paradoxos da sociedade contemporânea: o movimento slow fashion. In: Colóquio de Moda. 7., 2010, Curitiba. Anais... Curitiba: 2010.

MOTTA, M.; CONTI, G. M. Knit design contemporary scenarios. In: Fashion and Design International Congress. 2., 2014, Milano. Anais... Milano: CIMODE, 2014.

NIINIMÄKI, K.; HASSI, L. Emerging design strategies in sustainable production and consumption of textiles and clothing. Journal of Cleaner Production, v. 19, n. 16, p. 1876-1883, 2011.

OENNING, J.; NEVES, M.; FESFOSCO, E. Slow fashion: a new path to te fashion design. In: International Fashion and Design Congress. 1., 2012, Guimarães.

Anais... Guimarães: CIMODE, 2012.

OZTURK, E. et al. Evaluation of integrated pollution prevention control in a textile fiber production and dyeing mill. Journal of cleaner production, v. 88, p. 116-124, 2015. JOUR.

PEREZ, I. U.; CAVALCANTE, A. L. B. L. Análise da ecoeficiência do processo de design de moda zero waste. Projetica, v. 5, n. 1, p. 41-56, 2014.

PEZZOLO, D. B. Tecidos-História. São Paulo: Senac, 2007.

PIRES, B.; AVELAR, S.; SANCHES, R. Textile body: 3D Knitting and biologic design. In: Intenational Fashion and Design Congress. 1., 2012, Guimarães. Anais...

Guimarães: CIMODE, 2012. 
PROVENZANO, C. C. Moda, inovação e sustentabilidade: estudo de casos múltiplos. 2014. Dissertação (Mestrado em Administração)—Universidade Federal do Rio Grande do Sul, 2014

QU, L.; ZHANG, T.; LIANG, S. Sustainable urban solid waste management from both life cycle and urban metabolism perspectives. In: Digital Manufacturing and Automation (ICDMA). 3., 2012, GuiLin. Anais... GuiLin: IEEE, 2012. p. 872-875

RANGEL, A. S.; SILVA, M. M.; COSTA, B. K. Competitividade da Indústria Têxtil Brasileira. Revista de Administração e Inovação, v. 7, n. 1, p. 151-174, 2010.

REDRESS. The EcoChic Design Award ZERO-WASTE design technique. [s.I.] Ecochic designaward, 2014.

ROOS, D. B. O Setor Industrial de Malharia Retilínea de Caxias Do Sul: um estudo de aglomerado de pequenas empresas. 2001. 117 f. Dissertação (Mestrado em Ciências Econômicas)—Universidade Federal do Rio Grande do Sul, 2001

RUTHSCHILLING, A. A. et al. Upcycling of rectilinear kniting yarn in sustainable fashion products. In: Intenational Fashion and Design Congress. 2., 2014, Milão. Anais... Milão: CIMODE, 2014.

SALCEDO, E. Moda ética para um futuro sustentável. Barcelona: Gustavo Gili, 2014.

SANCHES, R. A avaliação de impacto ambiental e as normas de gestão ambiental da série ISO 14000: características técnicas, comparações e subsídios à integração. 2011. 270 f. Dissertação (Mestrado em Engenharia Ambiental)— Universidade de São Paulo, São Carlos, 2011

SANT'ANNA, P. Moda: uma apaixonante história das formas. Ciência e Cultura, v. 61, n. 1, p. 50-53, 2009.

SCHULTE, N. K. Contribuições da ética ambiental biocêntrica e do veganismo para o design do vestuário sustentável. 2011. 174 f.Tese (Doutorado em Artes e Design), Rio de Janeiro, 2011

SEBRAE. Desenhar não é o bastante para empreender em moda: perfil de négocio da moda. Recife: SEBRAE, 2014.

SENAGA, M. Pequenas empresas e universidades são incentivadas a adotar e disseminar a prática da Produção mais Limpa. CETESB. 2010. Disponível em: <http://www.cetesb.sp.gov.br/2010/09/15/pequenas-empresas-e-universidades-saoincentivadas-a-adotar-e-disseminar-a-pratica-da-producao-mais-limpa/>. Acesso em: 16 jun. 2014.

SENAI. Ações do SENAI para o desenvolvimento sustentável. Brasília:

SENAI/DN, 2012. Disponível em: <https://static-cms-

si.s3.amazonaws.com/media/filer_public/fd/44/fd44e2a2-f481-4d44-8f3f-

91faf46ef112/20131003104837523130u.pdf>.

SENAI. Produção mais Limpa em confecções. Porto Alegre: Centro Nacional de 
Tecnologias Limpas SENAI, 2007. Disponível em:

$<$ http://institutossenai.org.br/public/files/producao-mais-limpa-em-confeccoespdf.pdf $>$.

SEVEGNANI, F.; SACOMANO, J. B. A estratégia de manufatura do setor de malharia retilínea pela análise do processo produtivo: o cluster do circuito das malhas. In: Congresso Nacional de Excelência em Gestão. 4., 2008, Niteroi. Anais... Niteroi: 2008.

SISSONS, J. Fundamentos de design de moda: malharia. Porto Alegre: Bookman, 2012.

UDALE, J. Fundamentos de design de moda: tecidos e moda. Porto Alegre: Bookman, 2009.

YIN, R. K. Estudo de caso: planejamento e métodos. Porto Alegre: Bookman, 2001. ZHANG, Y. et al. Life cycle assessment of cotton T-shirts in China. The International Journal of Life Cycle Assessment, v. 20, n. 7, p. 994-1004, 2015. 


\section{APÊNDICE A - A situação da maquinaria Stoll}

Questões relacionadas ao meio ambiente e a redução do consumo de energia tem se tornado cada vez mais relevantes no setor têxtil. Desta maneira as empresas fornecedoras de maquinaria se preocupam no desenvolvimento de seus equipamentos, o que é evidenciado na "Stoll" que cria suas máquinas sempre procurando atender a sua clientela (malharias), estabelecendo novos padrões para a produção de tricô, neste caso trabalhando com a introdução do pacote do aumento da produtividade e ao mesmo tempo reduzindo o consumo de energia.

Durante entrevista a representante da Stoll - Paramalhas forneceu alguns catálogos e folders, nos quais foi possível verificar questões técnicas de algumas máquinas e questões voltadas à economia de energia das mesmas. Um deles informa sobre a máquina CMS 502 HP+ (Figura 19) e dentre suas vantagens há o controle monofásico e a redução no fornecimento de energia.

Figura 19 - Folder da máquina CMS $502 \mathrm{HP}+$

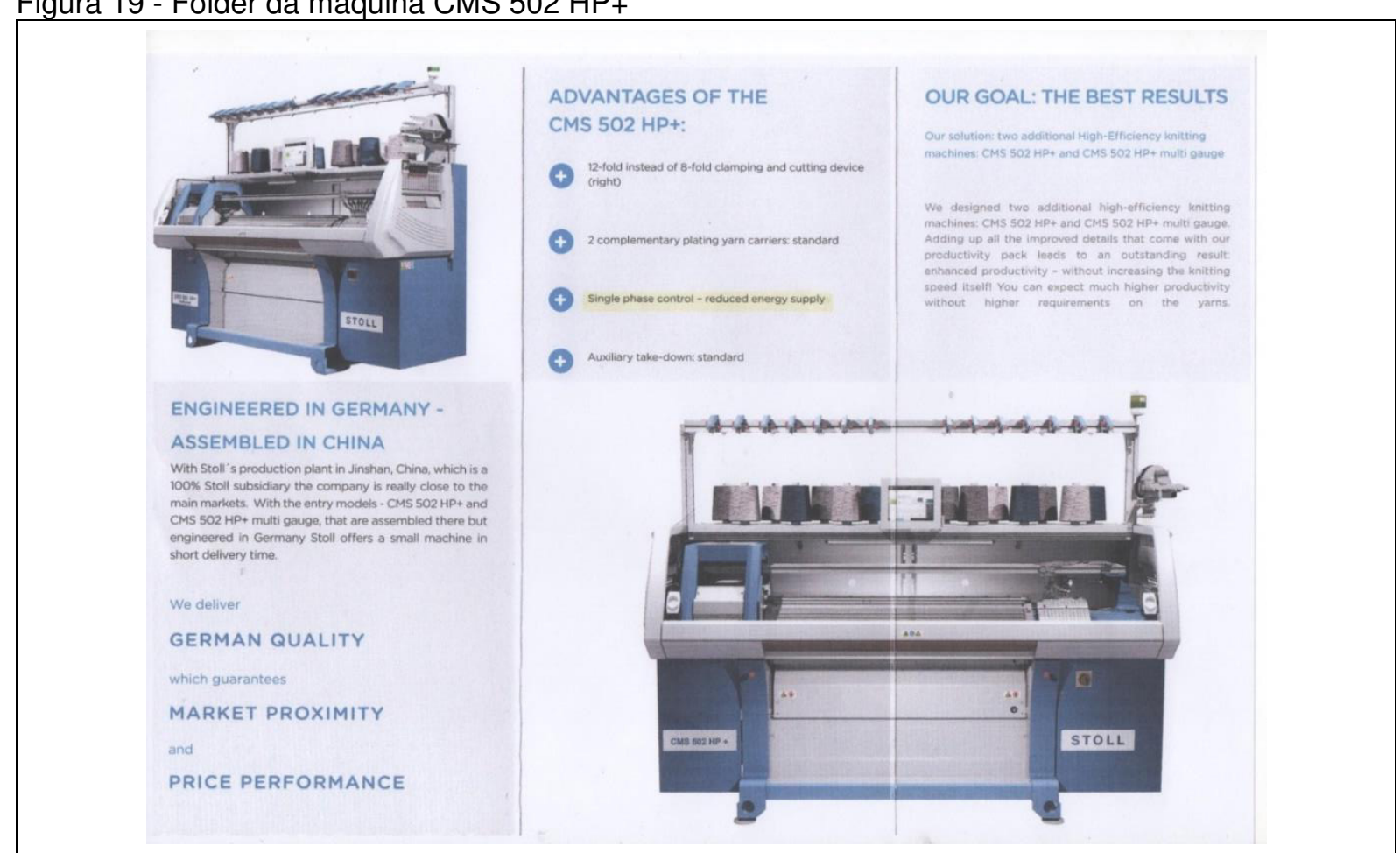

Fonte: elaborado pela autora ${ }^{6}$.

Outro catálogo é o da máquina "CMS 502 / 502 multi gauge", neste modelo de máquina, pode-se perceber a possibilidade de se usar finuras diferentes, em que

\footnotetext{
${ }^{6}$ Material fornecido pela Empresa Stoll em entrevista realizada pela autora no ano de 2017.
} 
exerce trabalhos tanto com finuras menores resultando em um tecido mais grosso e encorpado, quanto em finuras maiores originando tecidos finos, leves e vazados.

Na Figura 20, nota-se que a máquina compacta trabalha com dois sistemas e neles compõe-se as seguintes galgas $E$ 3, 5.2, 6.2, 7.2 e 8.2. Foram encontrados dados nestas informações sobre o fator do consumo da energia que pode ser variado de acordo com o tipo de malha a ser produzido, devido às possíveis variações desta maquinaria. Porém há especificações de que este modelo de equipamento utiliza de uma potência notavelmente menor do que a especificada, isto ocorre indiferentemente do tipo de finura abordada.

Figura 20 - Informação do catalogo da máquina CMS 502 multi galga

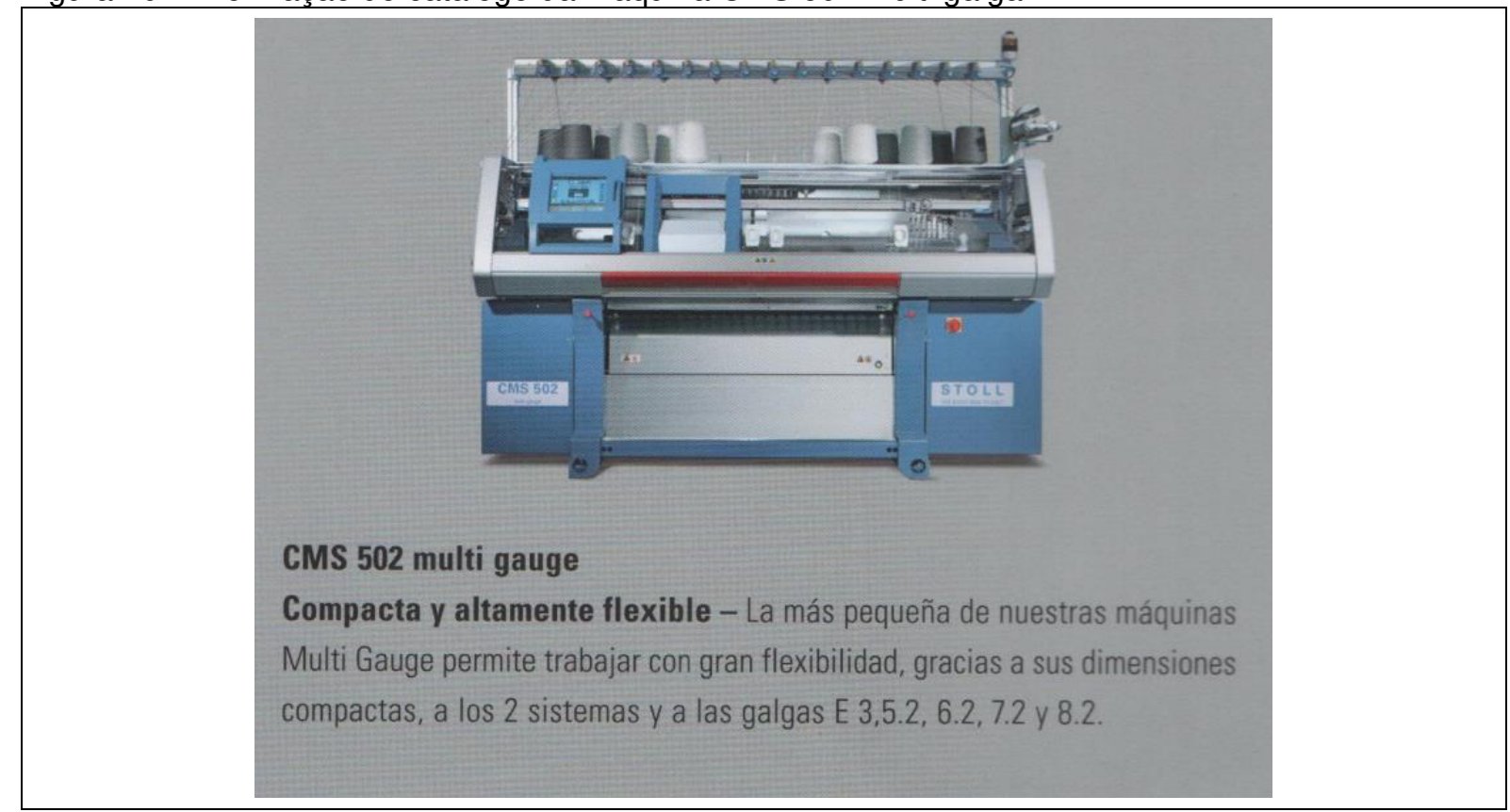

Fonte: elaborado pela autora ${ }^{7}$.

A respondente Monica representante da Maquinaria Stoll, relata sobre a empresa que é fabricante pioneira em maquinaria retilínea, e uma das principais fornecedoras de equipamentos que abastece o polo industrial de Monte Sião. Apresenta a empresa: "A Stoll é uma máquina Alemã tem 145 anos de história [...] Aqui no Brasil a representante é a Paramalhas que tem 43 anos de história no roll em máquinas retilíneas" (informação verbal) ${ }^{8}$. Em visita in loco nota-se a imensidão de amostras de padronagens, como na Figura 21, alguns exemplos que caracterizam as malhas deste tipo de maquinaria.

\footnotetext{
${ }^{7}$ Material fornecido pela Empresa Stoll em entrevista realizada pela autora no ano de 2017.

${ }^{8}$ Informações fornecidas pelo respondente Mônica representante da Maquinaria Stoll em entrevista realizada pela autora no ano de 2017.
} 
Figura 21 - Amostra de malhas, Stoll.

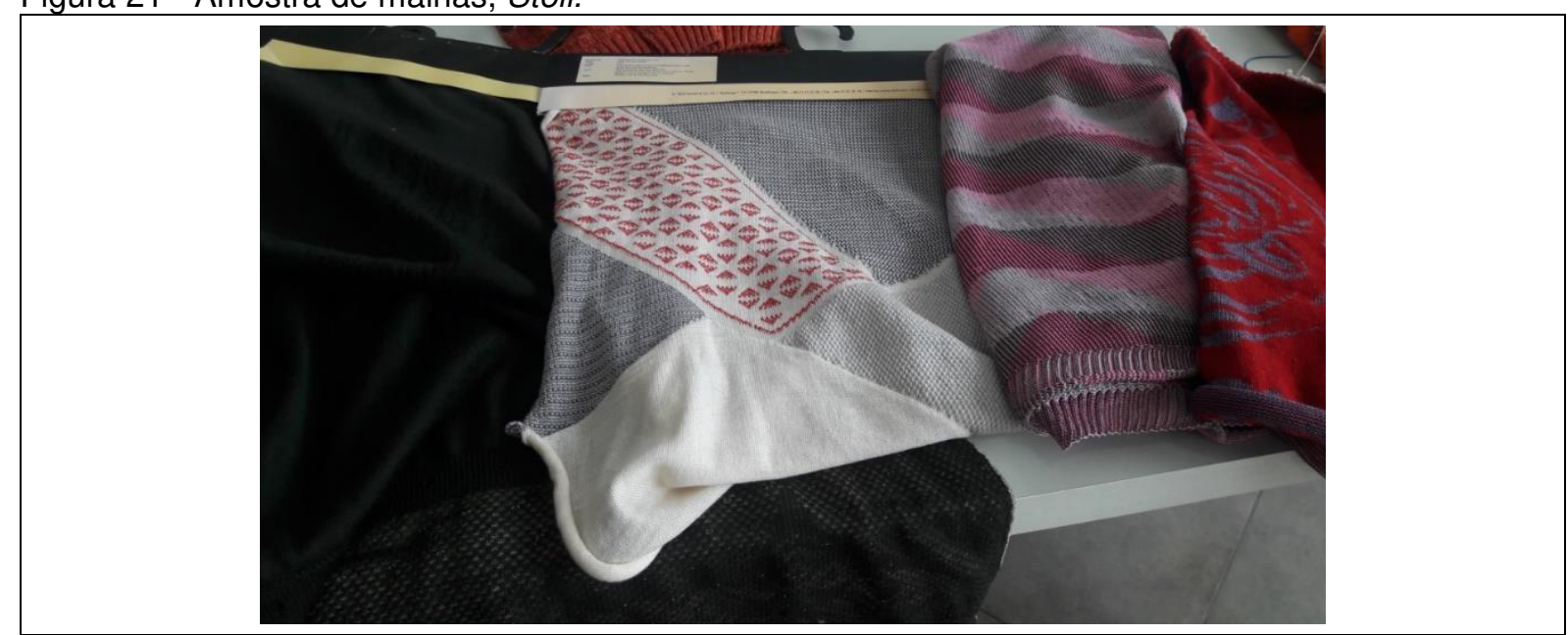

Fonte: foto da autora.

Na Figura 22 visualiza-se uma das máquinas da fornecedora Stoll encontrada na loja de demonstração, em que respondente informa que as máquinas do mostruário têm a intenção de apresentar aos lojistas suas facilidades e funcionalidades, desta maneira foi possível ver a máquina em funcionamento por alguns minutos na produção do que seria o início de uma peça.

Figura 22 - Maquina Stoll

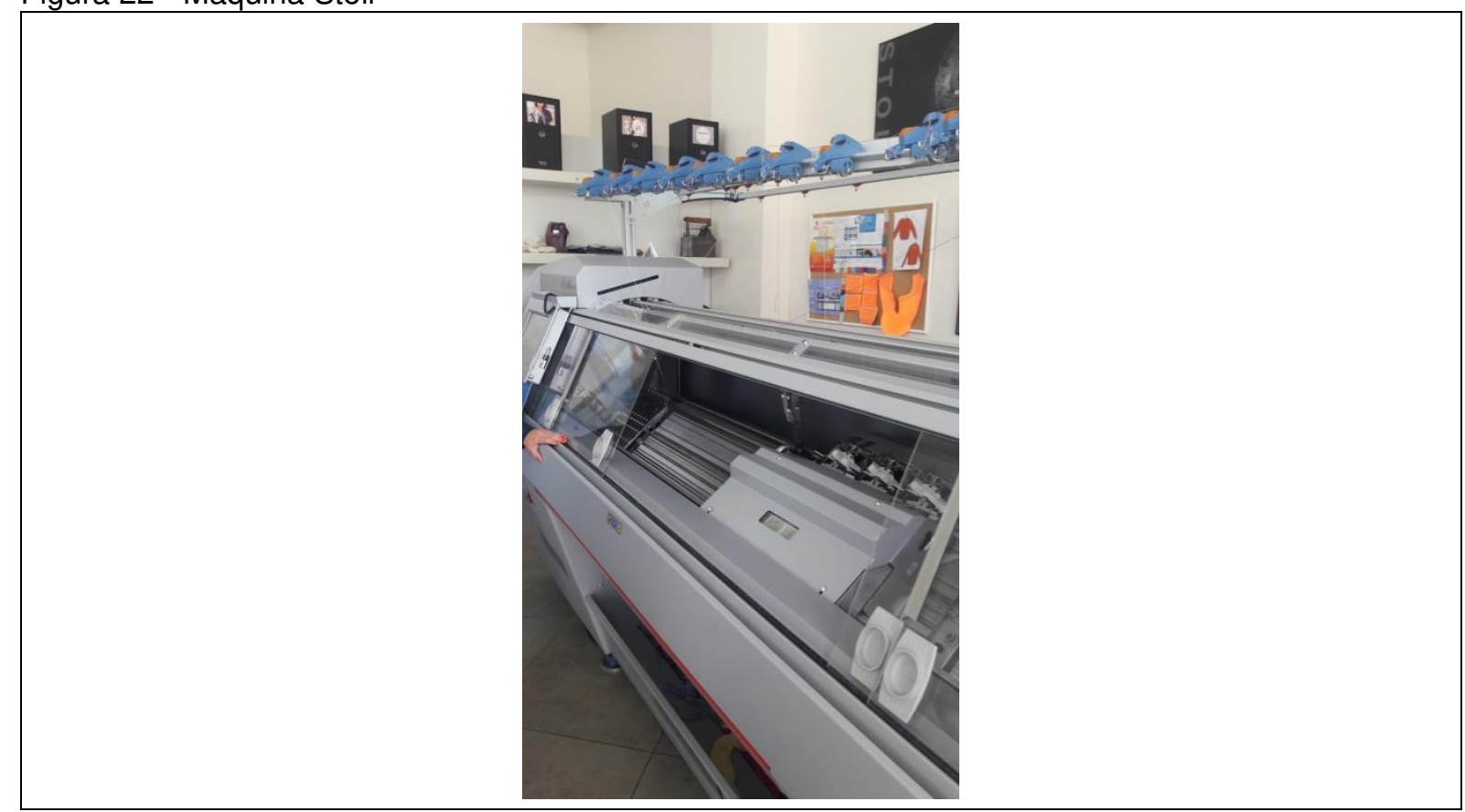

Fonte: foto da autora.

Explica um exemplo para que então se perceba a evolução e como as técnicas de tecimento sofreram alterações com o passar dos anos, evidencia também vantagens quanto ao processo de manufatura da roupa, sobretudo de como as máquinas se encontram cada vez mais aperfeiçoadas, de modo a intercalar acessórios que 
dispõem de funções principais para com as realizações de intermédio entre uma operação e outra, neste sentido de forma automatizada.

Continua a exemplificar que o processo de "painel" é um quadrado com padrões de medida, significa que será cortado no modelo desejado, produzindo assim os resíduos que são gerados a partir do contorno do decote, modelagem do corpo e da manga e assim por diante conforme necessário.

Neste contexto, começa a relatar algumas diferenças que possuem uma máquina de painel de uma máquina compacta em que esta última se difere por possuir os seguintes acessórios: pente, pinça, tesoura e alimentador positivo

Com relação a um dos processos de fabricação de roupas com estes maquinários a mesma descreve o processo sequencial, quando se faz uma peça, por exemplo, com técnica de calado separando-se frente, costas e mangas, relata também qual a vantagem neste tipo de tecimento. Direcionada a uma grande produção, a máquina é programada na sequência das realizações desejadas, fazendo a quantidade de frentes necessárias depois costas e mangas, a vantagem é que quando uma parte sai com defeito, poderá repor esta sem problemas, tecendo mais uma completando a grade de pedidos. Porém, ainda neste processo sequencial há o fio de separação de uma peça para outra e alguns cortes para modelar a roupa, ou seja, ainda gera resíduos.

Também considera-se, uma margem de perda para se iniciar a roupa onde existe a entrada do pente na máquina (pente acessório que permite a inserção do fio nas agulhas), deste modo estas primeiras carreiras de inserção são uma barra de segurança apenas para garantir que o tecido já está sendo fabricado, e que então pode-se realizar a peça.

Em sequência a responsável oferece um parecer com relação à economia do tipo de máquina compacta.

A economia de resíduo com este maquinário compacto que possui estes acessórios (pente pinça tesoura alimentador positivo), é enorme: porque você pensa em grande produção onde economiza o fio, a separação, matéria-prima, o tempo e o tecelão (informação verbal) ${ }^{9}$.

Segundo dados da respondente com relação a um dos tipos de divulgação da maquinaria esta é realizada na FEBRATEX (Feira Brasileira para a Indústria Têxtil)

${ }^{9}$ Informações fornecidas pelo respondente Mônica representante da Maquinaria Stoll em entrevista realizada pela autora no ano de 2017. 
que comporta inúmeros itens do setor têxtil, dentre eles, os que correspondem a malharia retilínea também estão presentes. Deste modo a Stoll participou fazendo uma demonstração do último lançamento que ocorreu em 2016 na cidade de Blumenau, na amostra, pode se constatar a realização do processo diminuído na peça pronta, em que se obtêm todas as partes já construídas e modeladas como pode se visualizar na Figura 23.

Figura 23 - Amostra de blusa infantil apresentada na FEBRATEX 2016

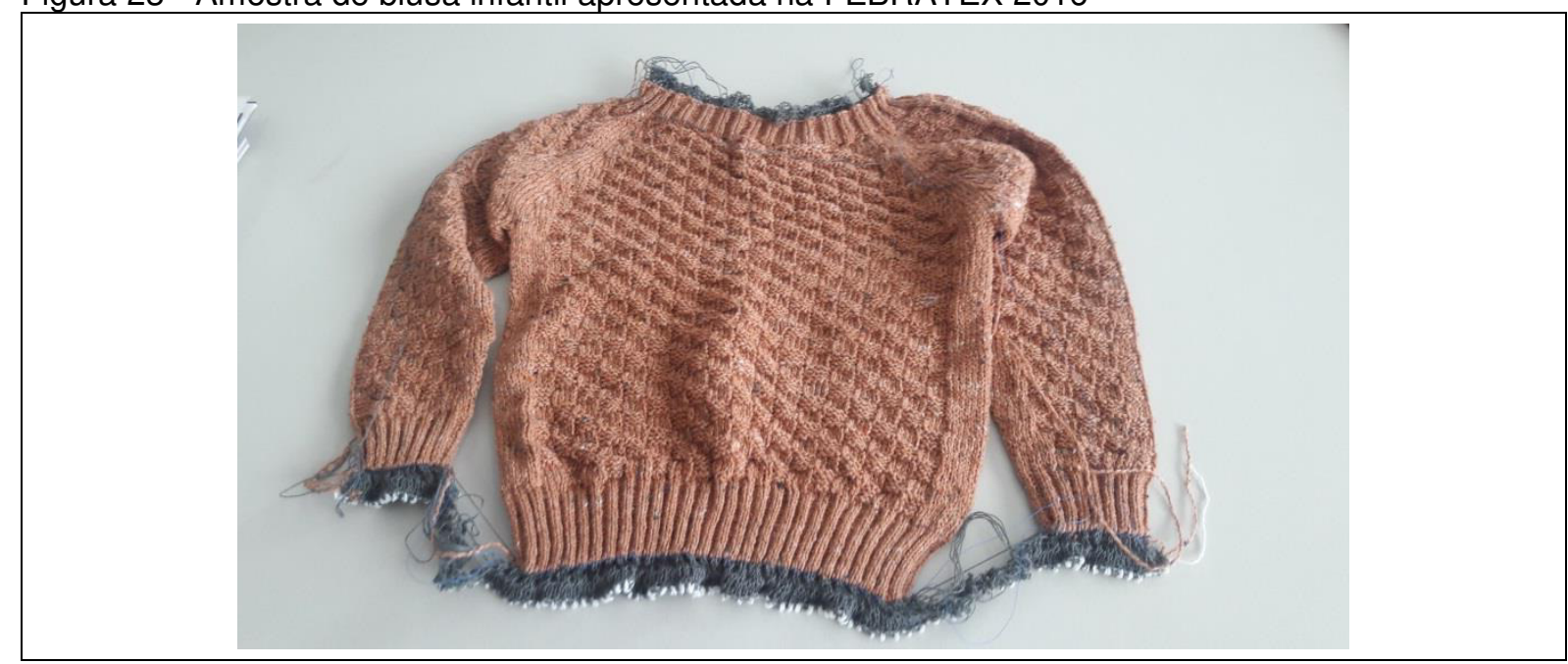

Fonte: foto da autora.

Neste processo, denota-se que no início da peça, parte inferior, em que à mesma começa a ser concebida simultâneas com as mangas, encontra-se a separação, e o fio de descarte, este material composto de elástico e fios próprios para separação são automaticamente entendidos como um resíduo que não tem mais função neste segmento. Nota-se que o decote também possui esta finalização de acabamento, ou seja, um resíduo também, e depois uma separação para se dar início a nova peça.

A partir do momento que a peça já está tecida para a realização das etapas finais, que são descritas como a fase de limpeza do fio de separação, o arremate das pontas que ocorre nas barras, decotes e terminações das mangas, a colocação da etiqueta e a vaporização final. Deste modo pode-se visualizar na Figura 24 como a peça é produzida. 
Figura 24 - Fluxograma do processo produtivo usando máquina de peça pronta

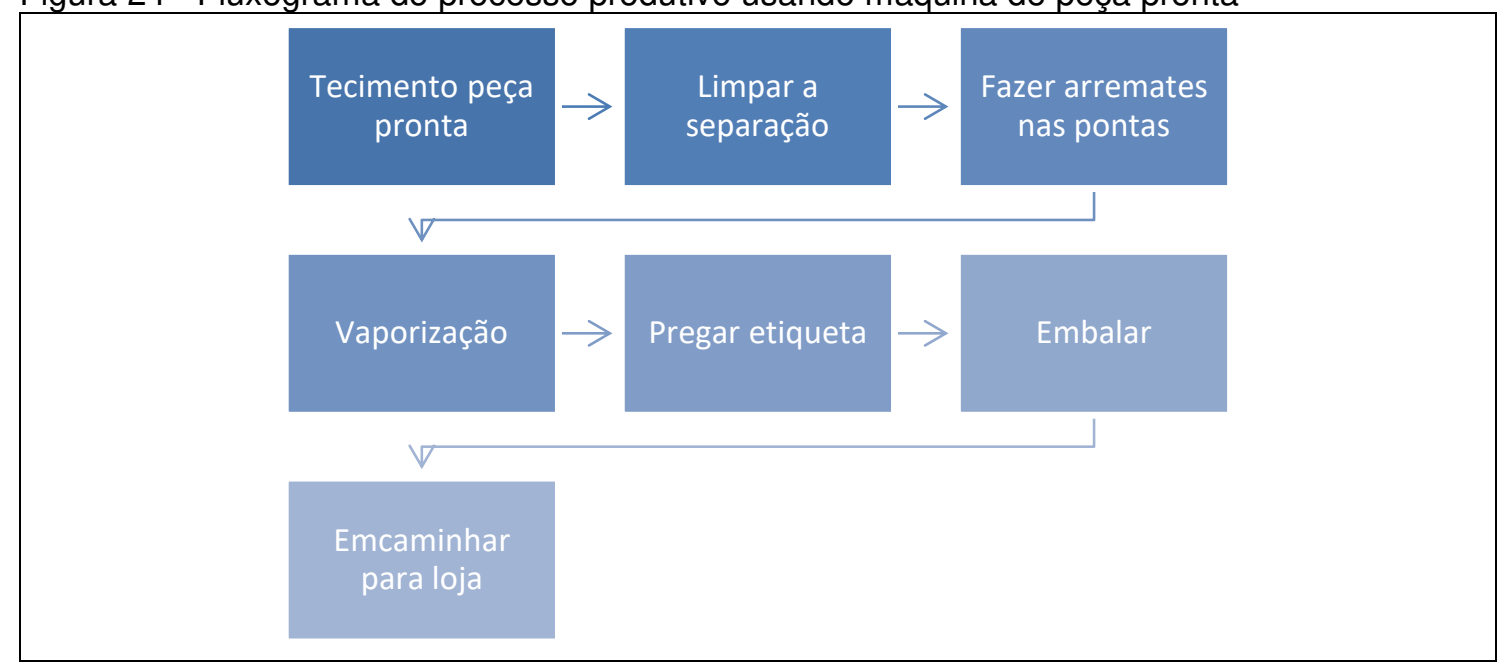

Fonte: elaborado pela autora.

No seguimento da malharia retilínea, segundo a respondente se o fabricante de malha conseguir alcançar uma produção de aproximadamente 50 ou 60 peças em um dia de trabalho é considerado um êxito muito grande, porque se comparada a outros tipos de obtenção de tecido como malha circular na fabricação de roupas o tempo é bem diferente, e consegue-se produzir maior quantidade em menor tempo, pois o procedimento é distinto. Neste contexto, ressalta, a valorização do produto de malharia retilínea.

Quando o equipamento não realiza peça pronta ele pode tecer as partes separadamente, ou seja, frente costas e mangas, neste caso o funcionário (tecelão), já pode realizar a limpeza do fio de separação e deixa as partes organizadas para serem enviadas para a costura e os procedimentos finais como mostra a Figura 25.

Figura 25 - Fluxograma do processo produtivo usando máquina de tecimento sequencial

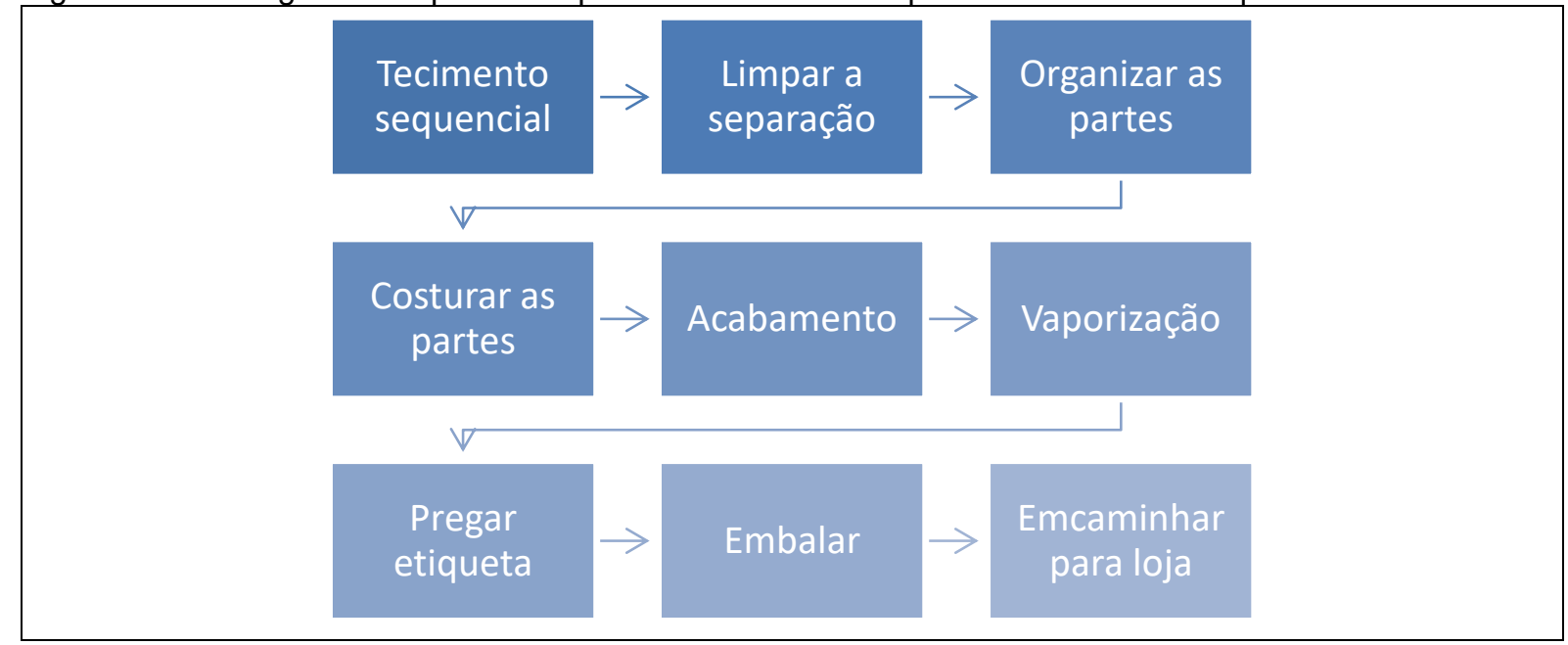

Fonte: elaborado pela autora. 
Neste contexto, como pode se verificar nos dois processos produtivos há uma quantidade diferente de etapas, sendo que em um processo denota-se mais fases e no outro tipo de maquinaria você economiza algumas etapas ganhando tempo de produção. Segundo a respondente a diferença da máquina que realiza a roupa pronta para a outra que não faz este processo é a distância da frontura, este é o principal diferencial entre um equipamento e outro.

A seguir acrescenta sobre o crescimento do polo industrial em que de acordo com seu relato está sofrendo alterações e se adaptando cada vez mais, com isto a chegada da máquina peça pronta está inserida nestas mudanças que estão ocorrendo gradativamente.

Ainda há na cidade muitas máquinas que fabricam roupas utilizando a maquinaria de frontura longa, esta é própria para a realização de tecidos chamados de painéis, deste modo, a máquina não possui acessórios e é específica para a realização de tecidos grandes, que serão modelados posteriormente. Neste contexto, de produção a respondente informa que é estimado a cada $1.000 \mathrm{~kg}$ de investimento de matériaprima $200 \mathrm{~kg}$ seriam resíduos.

Destaca-se a seguir o modelo de máquina "502 compacta" que realiza peça pronta, possui acessórios, é rápida e mais acessível. Segundo a entrevistada neste ano de 2017 esta é uma máquina popular e a mais encontrada no Brasil. Estima-se que para este equipamento segundo a respondente a cada $1.000 \mathrm{Kg}$ de investimento de matéria-prima $30 \mathrm{Kg}$ seriam resíduos, estes dados podem sofrer alterações quanto a diferentes modelos, matérias primas e finuras utilizadas.

No ambiente visitado para a realização da entrevista foi possível verificar modelos de peças produzidas por maquinária Stoll são amostras para que os clientes possam ter ideia do que cada maquinário é capaz de produzir, todos os modelos são fornecidos pela sede da empresa que se encontra na Alemanha, e possuem etiquetas indicando além dos pontos e cores, o tipo de maquinário e o designer para cada produto, neste contexto foi possível verificar alguns looks e suas estruturas.

Na Figura 26 é possível verificar no vestido vermelho o tecido de malha sendo construído com desenhos aleatórios, que proporciona caimento diferenciado e ao mesmo tempo em que traz leveza oferece um movimento na parte inferior do mesmo, formando bicos laterais. Para completar o look tem-se uma jaqueta de zíper manga 
curta, em tom de cinza com listras finas azuis e vermelhas feita em malha grossa, ganha um visual que é trabalhada no lado avesso possuindo características de volume e maciez.

Figura 26 - Look composto por vestido e jaqueta

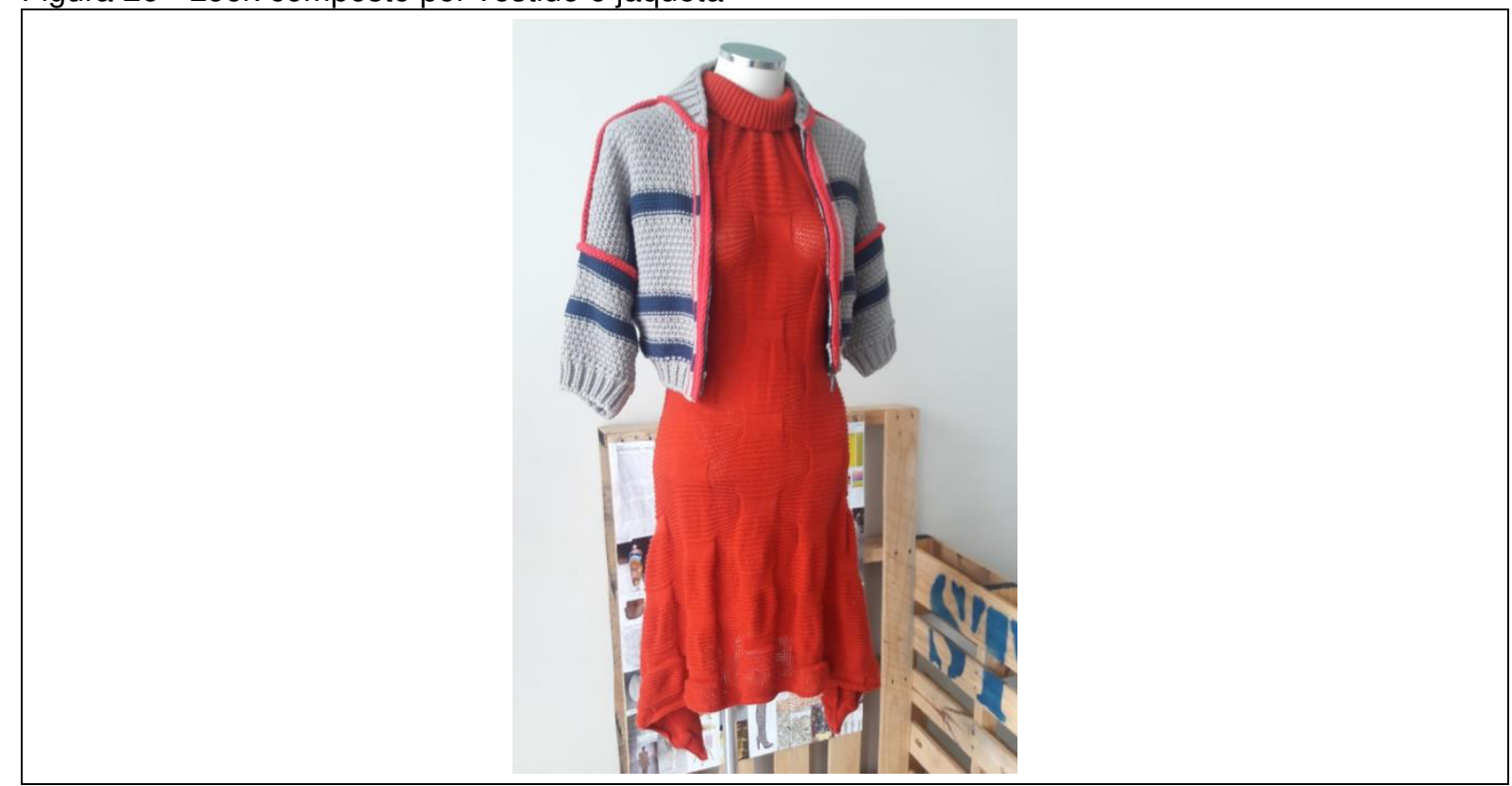

Fonte: foto da autora.

Tem-se a apresentação de uma jaqueta com acabamentos em jeans e base em malha (Figura 27), esta padronagem é toda listrada em tons de cinza, azul, bege, marrom, vermelho e branco. Formando composição com a blusa em malha na cor azul jeans que recebe um decote "V" com aplicação de três camadas de texturas diferentes.

Figura 27 - Look composto por jaqueta casual jeans malha, blusa e calça clean.

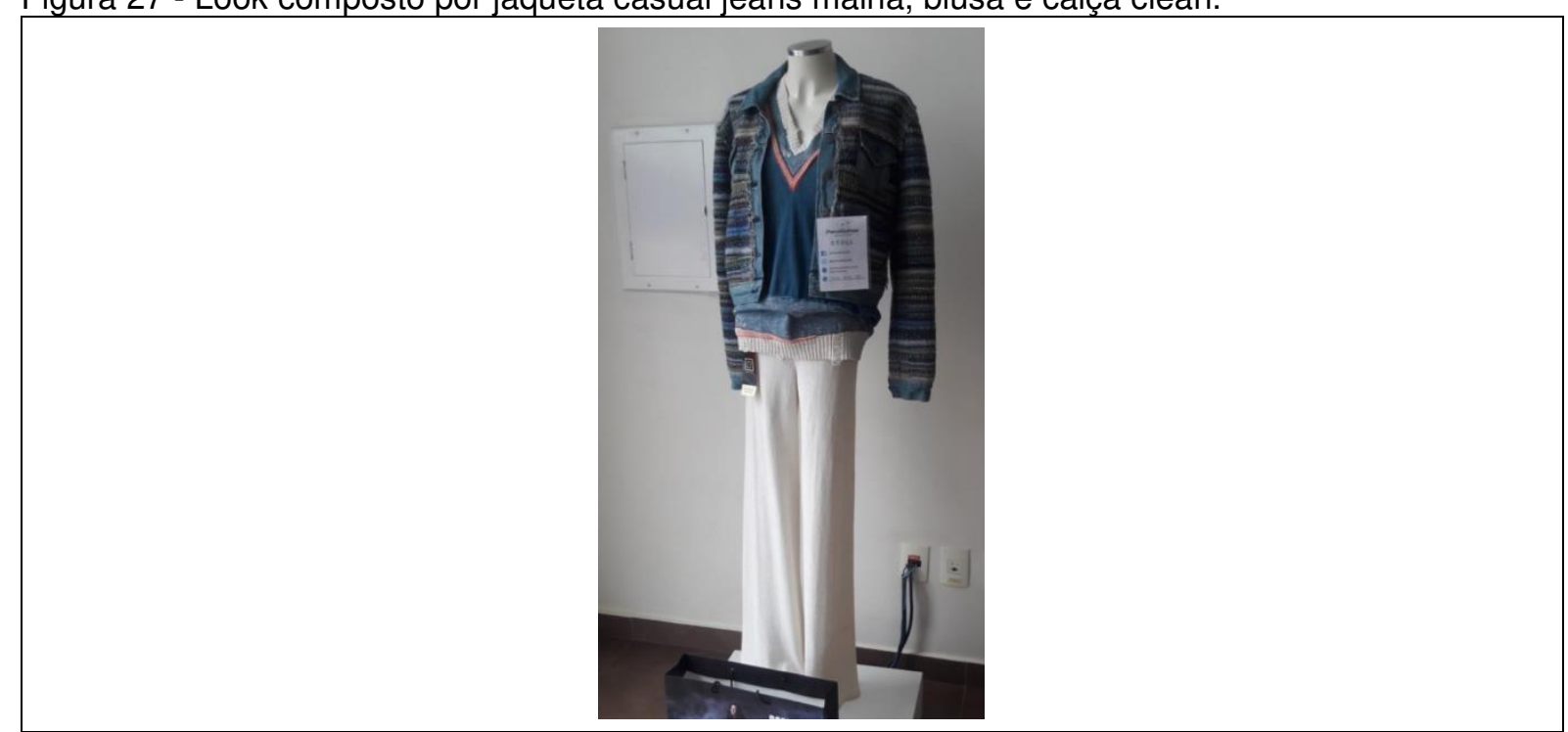

Fonte: foto da autora. 
Além de trabalhar com vestuário, também foi possível verificar que a maquinaria Stoll produz acessórios como calçados, realizados em máquina de peça pronta, porém com uma programação de software diferenciada. Em que a respondente relata que o tênis de malha tricô leve e confortável.

O calçado modelado em máquina de peça pronta pode ser feito sequencialmente um após o outro, destacados pela separação. Verifica-se a estrutura da modelagem do tênis na Figura 28, bem como percebe-se a diminuição da proporção, denotando-se os contornos necessários, em que se obtém um pé do calçado a cada separação, visualizando-se também o design e estrutura do modelo que pode ser diversificado conforme o estilo proposto.

Figura 28 - Calçado modelado lado direito/avesso

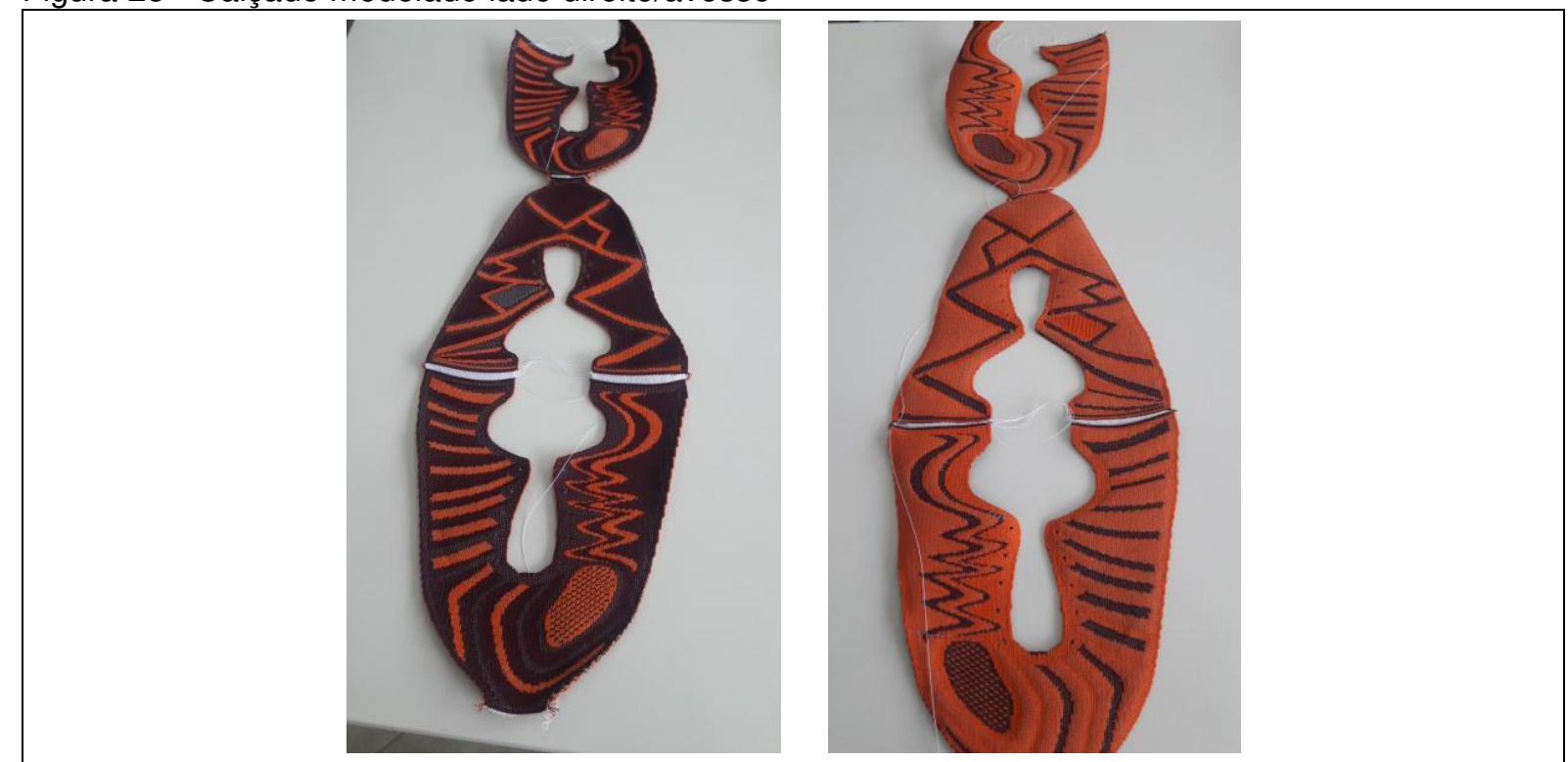

Fonte: foto da autora.

No decorrer da estrutura são trabalhados pontos diferenciados, que proporcionam texturas e maleabilidade direcionando movimentos onde existe a necessidade. Neste cenário pode-se visualizar também que conforme a modelagem é realizada são feitos os furos para colocação do cadarço. Na Figura 29 pode-se visualizar o calçado finalizado. 
Figura 29 - Amostra de tênis realizado em máquina de peça pronta Stoll

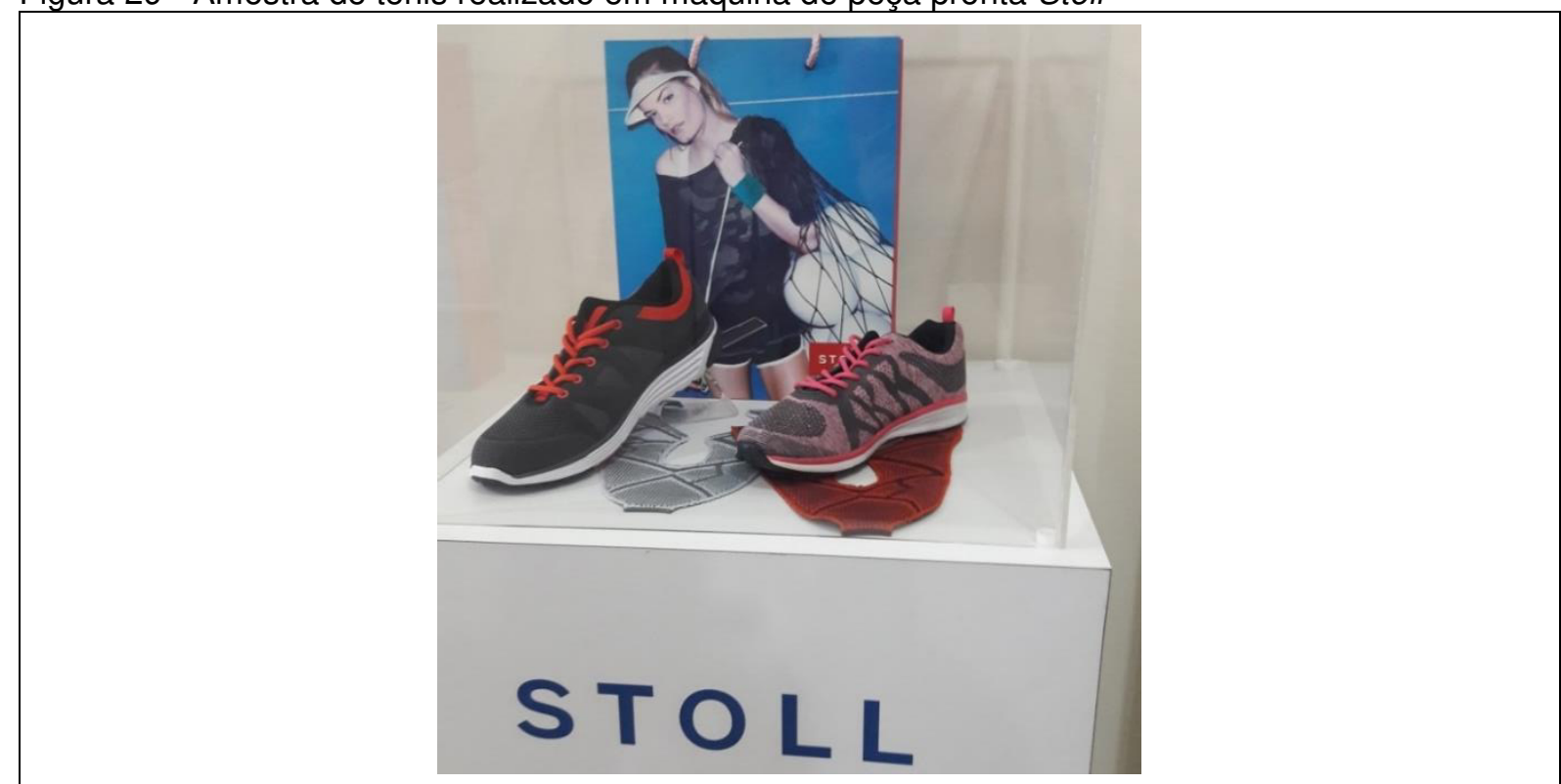

Fonte: foto da autora.

Há uma ampla diversificação de produtos que podem ser explorados deste tipo de processo, e este é crescente, pois constantemente são apresentadas novas tecnologias no mercado proporcionando avanços significativos tanto com relação a vestuário quanto acessórios. 


\section{APÊNDICE B - A situação da instituição "Mosteiro Santíssima Trindade"}

O "Mosteiro Santíssima Trindade" está situado nos arredores da cidade de Monte Sião é uma das instituições voltadas e realizar remanufatura de resíduos têxteis de tricô. A instituição possui outros projetos além deste, e cada um é representado por um grupo de monges, para responder a presente pesquisa contatou-se o Ir. Silvio e a Ir. Damaris, uma das responsáveis pelo desenvolvimento do trabalho, que prontamente respondeu todas as questões e apresentou o local.

A respondente relata como surgiu a ideia de trabalhar com resíduos no mosteiro "primeiro [...] angariar fundos para construção do novo mosteiro" (informação verbal) ${ }^{10}$ é com este objetivo que se elaborou o projeto. Com este depoimento a respondente declara sorrindo que se dedicam ao projeto dos resíduos com muito empenho, pois todos sabem da importância deste trabalho, e o valor da conquista a cada etapa. Salienta também, que este faz parte de muitos outros projetos relevantes desenvolvidos por eles, porém tem uma paixão e um apego para com este em especial, porque acredita de alguma maneira contribuir para um bem maior uma vez que trabalha com aquilo que já foi descartado, atribuindo a este um novo caráter, remanufaturando algo que seja belo e possível de ser apreciado.

Explica que todas as tarefas são feitas por eles dentro do local, isso inclui tanto alimentação quanto suas roupas, pois todos eles são aptos para desenvolverem a costura. Dentro deste contexto relata sobre o projeto de resíduos, que as situações foram aparecendo naturalmente, pois no local, se recebem doações variadas e dentre elas começou-se a receber muitos tecidos de malhas, com entusiasmo conta que então olhava para aquele montante que crescia e pensava o que poderia fazer com todo aquele material.

Não foram citadas informações a respeito da quantidade de material recebida, por não possuírem um controle das doações, até porque o projeto é novo, eles não fazem ideia do que tem em quilos, porém acrescentou recebem o ano todo doações de diversos tipos.

${ }^{10}$ Informações fornecidas pelo(a) respondente do "Mosteiro Santíssima Trindade" em entrevista realizada pela autora no ano de 2017. 
Na Figura 30 pode-se visualizar como são separados os resíduos que são de malha, para depois se fazer uma triagem mais minuciosa dos materiais.

Figura 30 - Caixas de resíduo de tricô armazenados atualmente em baixo da mesa do corte Mosteiro setor de confecção.

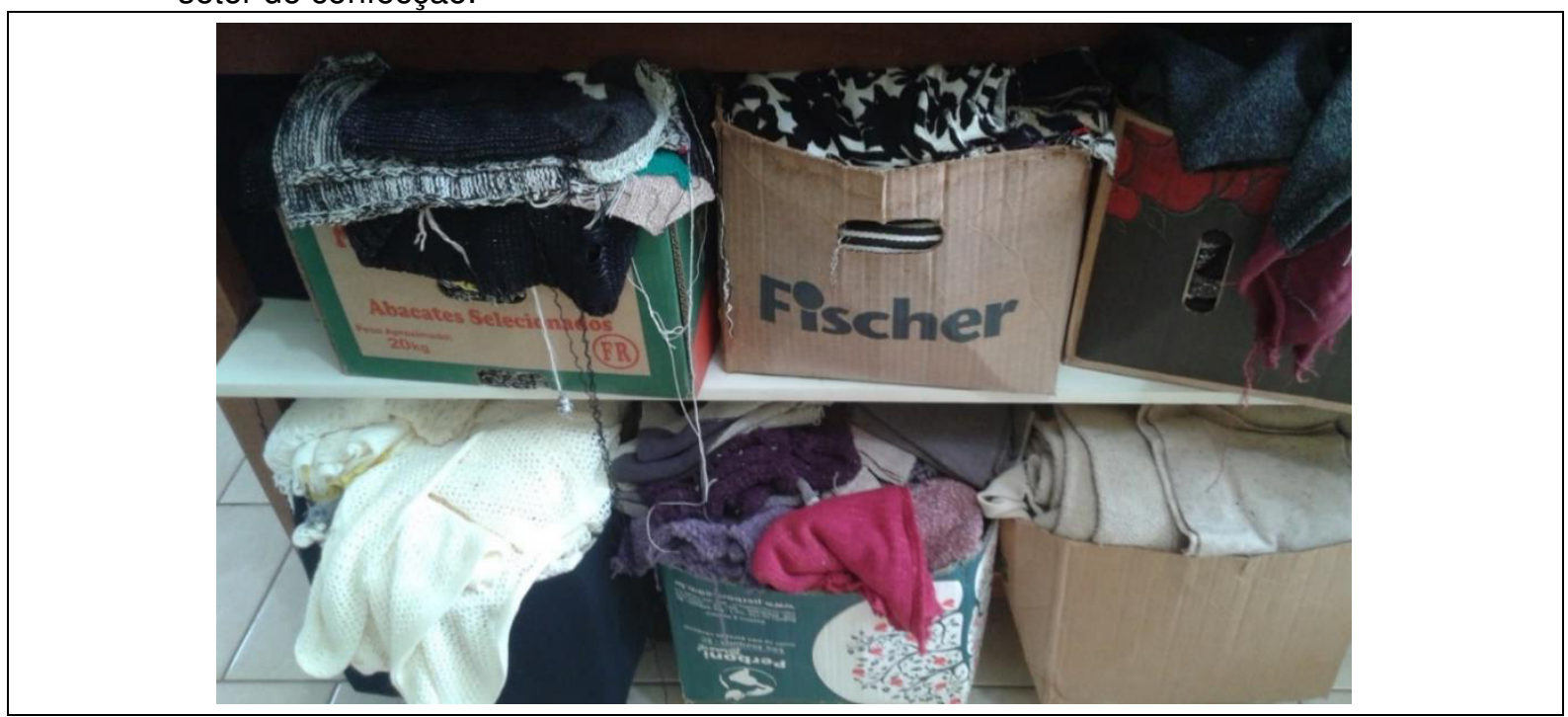

Fonte: foto da autora.

Deste modo, pode-se visualizar também que os pacotes de doações, como mostra a Figura 31, são diversos e variados. Observou-se no estabelecimento alguns recipientes de plásticos de aproximadamente 100 litros, a serem separados ainda quanto ao tipo de retalho e cor, e que estavam armazenados ao redor da mesa de corte aparentemente muito robusto, no qual continham uma mistura de retalhos.

Figura 31 - Pacote de resíduos doados ao mosteiro.

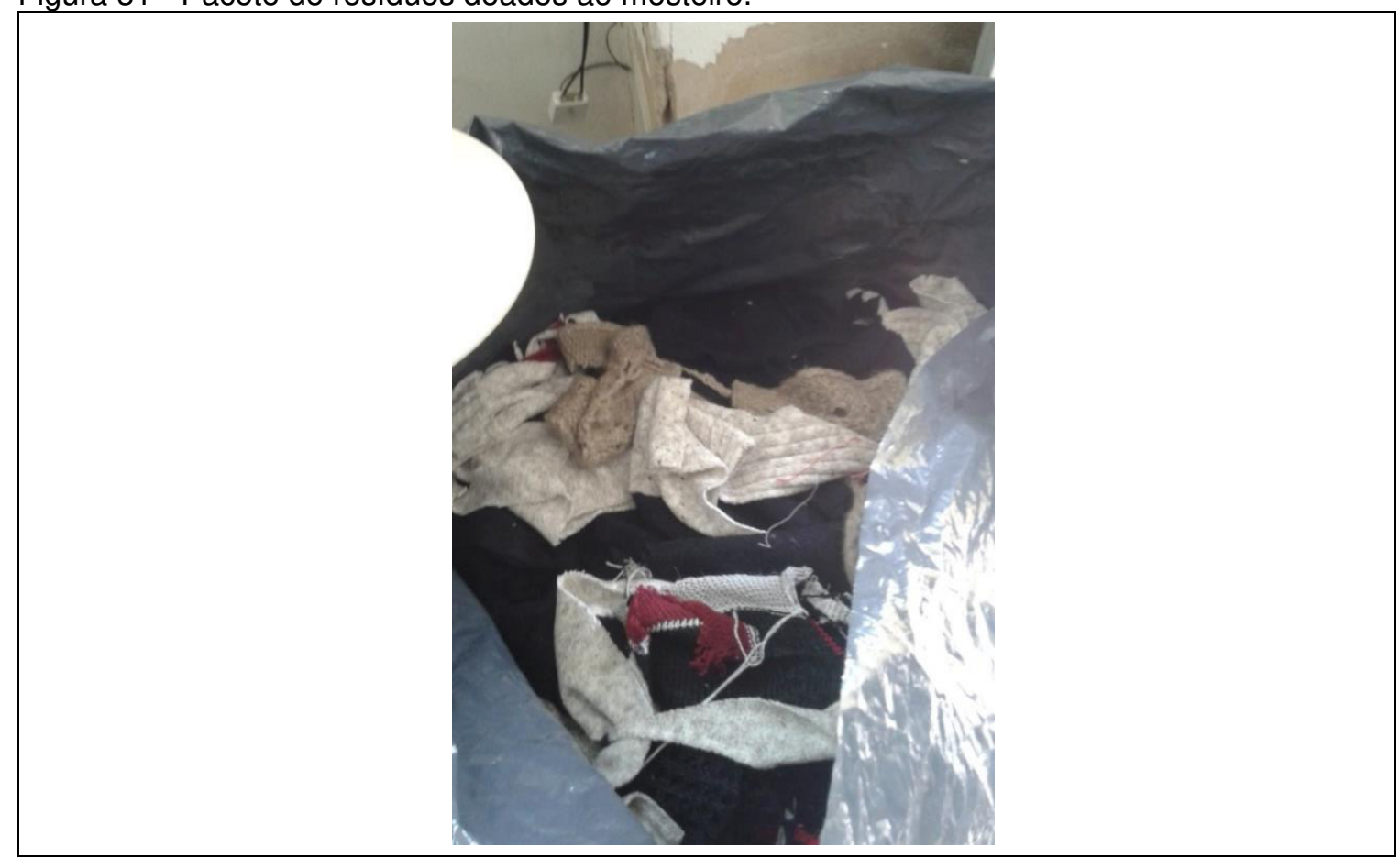

Fonte: foto da autora. 
Do mesmo modo pode ser vista na comunicação da entrevistada que deixa uma transparência em satisfação para com a realidade da experiência vivenciada até o momento, nota-se que ao mostrar cada item expressa uma alegria e permite um desprender daquela tarefa de maneira a não ser encarada como um trabalho e sim como um prazer de transformar. Também deixa a entender, que não imaginava ter tanta amplitude na execução deste, mais relata que o projeto foi crescendo todos foram gostando e colaborando e hoje ele é maior.

Em seguida transcorre, que com o desenvolvimento começaram então a produzir nas duas estações do ano, denominando todas as peças feitas para o inverno de Patchwork de tricô, devido a forma como apresentaram-se na construção da peça. Pode-se entender neste sentido que utilizam esta expressão para emoldurar um tipo de arte diferente, já em temporadas de clima mais quente fazem uso dos tecidos simples, criando vestidos de viscose por exemplo.

No contexto que ressalta a pesquisa de campo percebe-se então como é direcionado o processo de remanufatura com retalhos de tricô (Patchwork). Primeiramente, quando chegam as caixas se faz uma separação rigorosa, adotando critérios de separação por cores, padrões, tamanhos que em seguida são armazenados nos compartimentos dos armários.

A Figura 32, mostra como são tratados os resíduos têxteis recebidos pelo mosteiro. Pode-se notar que são selecionados e separados por tons próximos, deste modo temse uma variedade de azuis e vermelhos, com uma diversidade de pontos assim formando texturas sobrepostas umas sobre as outras.

Figura 32 - Seleção de malhas por cor.

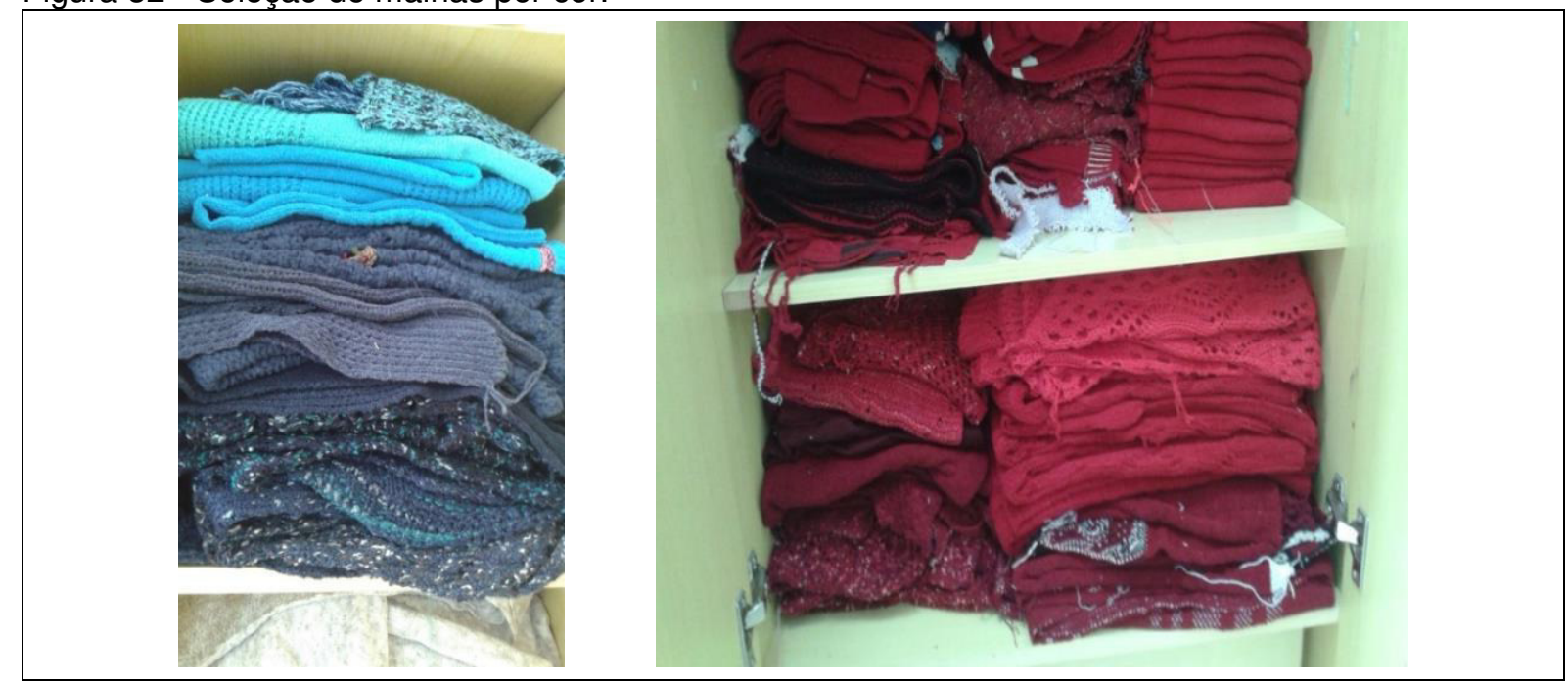

Fonte: foto da autora. 
Nos armários, são colocados os tecidos devidamente dobrados, onde pode-se notar uma organização na sua sequência, pois esta é uma primeira etapa no qual permitirá o surgimento da criação de peças posteriormente.

Em outro momento, é que se analisa o que poderá ser feito com aquele retalho, então se entende que primeiramente existe uma predefinição de cores. Ainda assim, não se sabe o que poderá sair daquela separação, é imprevisível se pensando em modelos. Neste contexto cabe-se dizer que o trabalho de retalho começa a ter início, segundo a respondente explica que é como um quebra-cabeça mesmo, experimenta um com outro, e vai pedindo a opinião de cada um deles, tudo é decidido em conjunto e com muito cuidado.

Neste contexto, também reforça que além de ter em mente o aproveitamento, precisa levar em consideração aquilo que possa agradar o seu cliente, com uma finalização criteriosa com o intuito de ficar bonito mesmo, para que as pessoas possam ver e chamar a atenção, do que é possível de se mostrar com o trabalho artesanal de preparação deste tipo de roupa.

Entende-se que procuram abordar uma fatia do mercado que aprecia diversidade com uma simplicidade, porém com muita qualidade e ao mesmo tempo elegância.

Denota-se, a percepção de artesanal de como atribuem a roupa o exercício de enriquecer com as aplicações de pedras, por exemplo, tornando o ofício um elemento único naquele universo de recortes, e trabalhos em ângulos diferentes, que recebem os apliques hora de camurça, como na Figura 33, hora de pérolas na Figura 34, tudo formando um complemento que vem a caracterizar um estilo descontraído e que passam a comunicar diferenciações, devido a sua procedência se tornando de certa maneira uma arte com peças que não serão repetidas. 
Figura 33 - Colocação renda sobreposta a camurça.

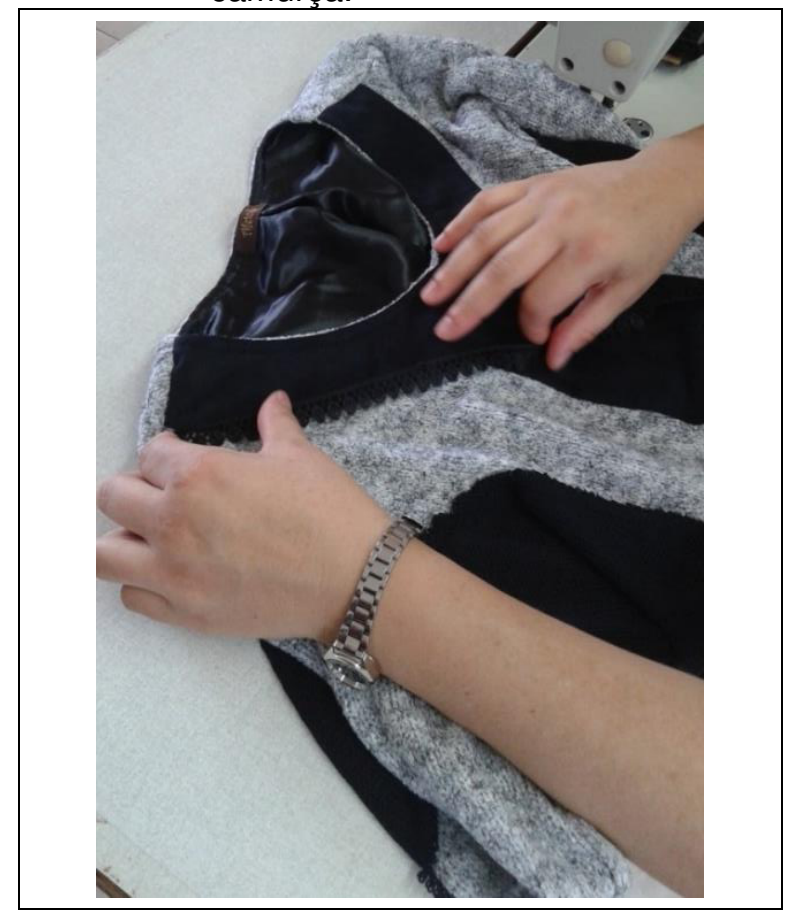

Fonte: foto da autora.
Figura 34 - Aplicação de camurça com bordado em perolas.

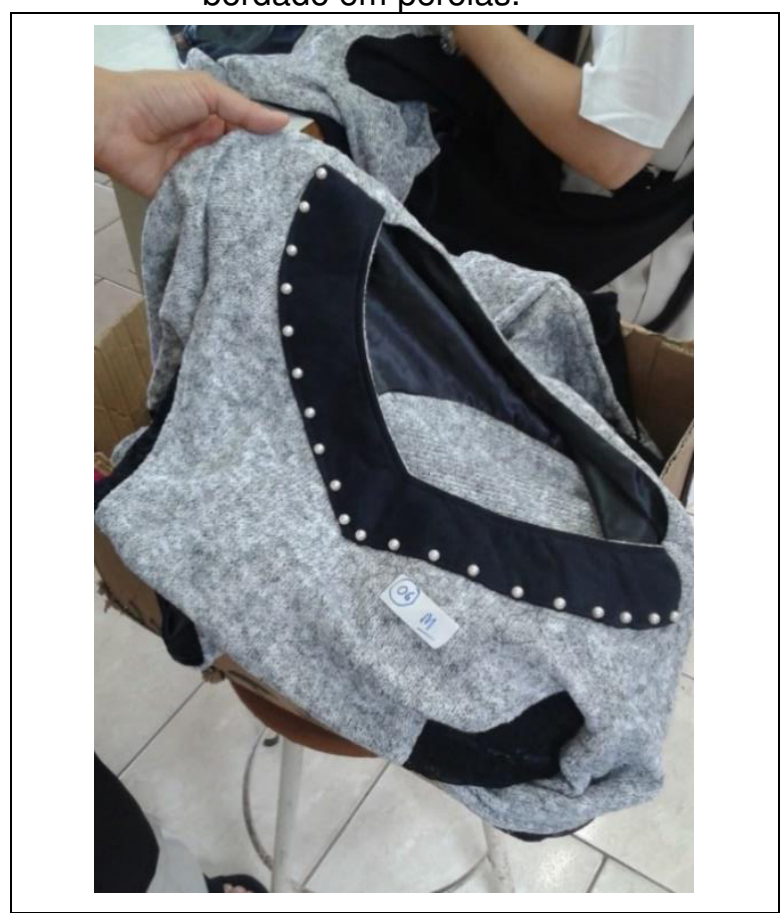

Fonte: foto da autora.

Tendo como peça principal a blusa, procuram diversificar neste modelo, através de recortes com texturas. Pode-se visualizar peças semi-prontas nas Figuras 35 e 36, que apresentam recortes em várias texturas, e apliques no decote em camurça, que posteriormente receberão acabamentos finais e bordados.

Figura 35 - Blusa semi pronta com detalhes texturas.

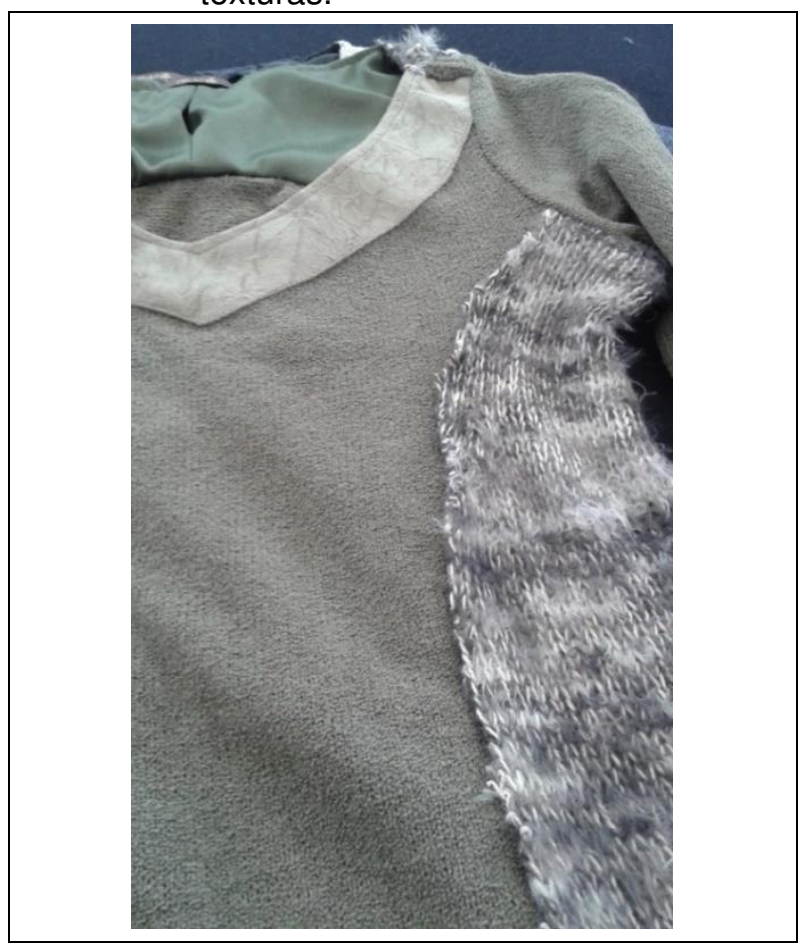

Fonte: foto da autora.
Figura 36 - Blusa semi pronta com abertura ombro.

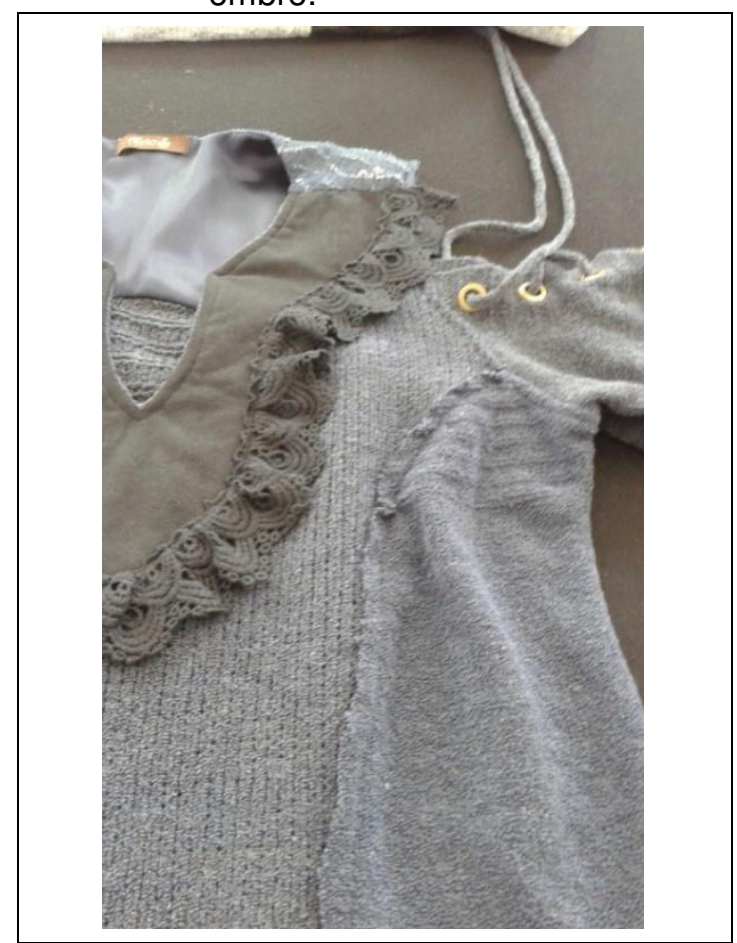

Fonte: foto da autora. 
Nota-se como permeiam as sobras do que é confeccionado pelo mosteiro "o que sobra da costura [...] resto de overloque aparas separam para a reciclagem [...] vendem para a reciclagem [...] quantidade que sobra é mínima" (informação verbal) ${ }^{11}$.

Observa-se, que a instituição dedicada a remanufatura dos resíduos de malharia exerce um ofício muito relevante, pois a todo o momento demostram o quanto é amoroso o tratamento para com os materiais e, além disto, o intuito de propor um benefício à cidade tratando os resíduos como matéria-prima.

Uma conscientização de se aproveitar ao máximo o que lhes foi doado e também com responsabilidade de se inserir algo que seja valioso para as pessoas. Neste contexto, evidencia-se que o trabalho de desenvolvimento de produto de remanufatura realizado como um quebra cabeça no Mosteiro com a doação de resíduos sólidos têxteis é muito cuidadoso e ao mesmo tempo significativo.

${ }^{11}$ Informações fornecidas pelo(a) respondente do "Mosteiro Santíssima Trindade" em entrevista realizada pela autora no ano de 2017. 


\section{APÊNDICE C - A situação da instituição de reciclagem}

Sr. Lacir, proprietário da reciclagem pesquisada, explica em seu depoimento o desenvolvimento do setor com o passar dos anos, relatando que antigamente as malharias fabricavam suas roupas usando uma modelagem a ser colocada em cima do tecido para depois serem cortadas, e que neste processo acontecia à geração do resíduo. Nota-se na entrevista uma grande satisfação no discorrer do diálogo, pois o respondente é uma das pessoas que se pode dizer conhecer muito bem do desenvolvimento da cidade e gostar muito do que faz. Proprietário atualmente da reciclagem "Pôr do Sol" fundada em 2003, relata que já foi proprietário de malharia por muitos anos e que tem visto muitas mudanças com relação a este segmento.

O setor de reciclagem visitado em 2016 e 2017 mostrou-se muito organizado, em que o trabalho com o resíduo é todo programado desde a entrada do material passando pelo processo de separação até a formação dos fardos, e depois armazenamento. Pode-se visualizar na Figura 37 que o local comporta uma estrutura com duas prensas bem próximas da mesa e das caixas onde serão manuseadas. Cabe ressaltar também que o material têxtil é recebido muitas vezes em pacotes plásticos e alocados no fundo do setor.

Figura 37 - Setor de reciclagem Pôr do Sol situada em Monte Sião, MG.

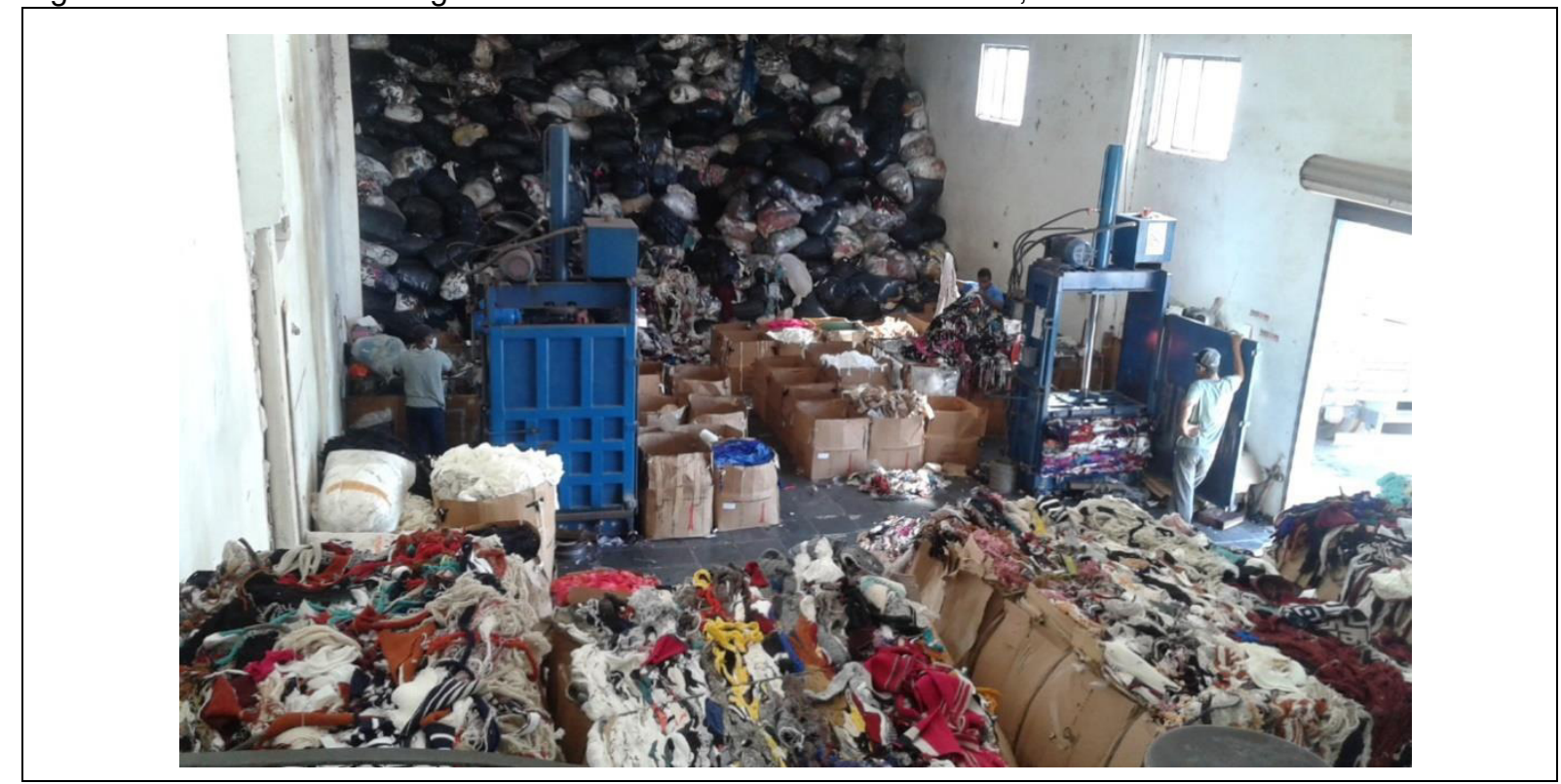

Fonte: foto da autora. 
Logo na entrada, encontra-se a balança como mostra a Figura 38, onde são pesados todos os resíduos antes de se dar início ao trabalho. Mais adiante encontra-se a empilhadeira (Figura 39), utilizada para locomover os fardos.

Figura 38 - Balança

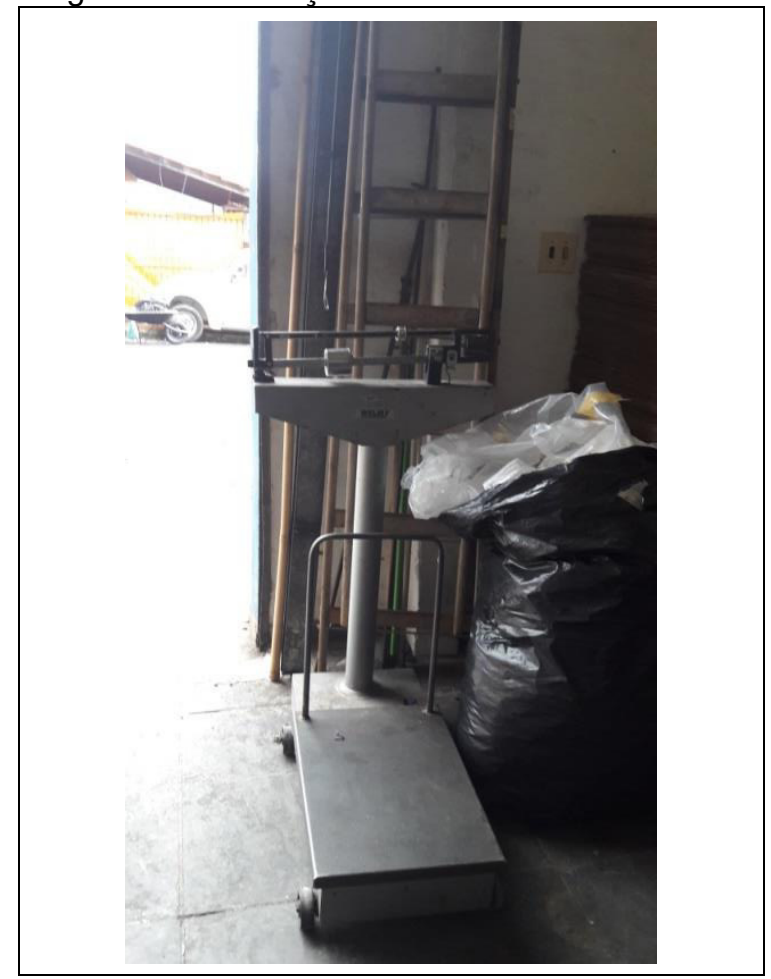

Fonte: foto da autora.
Figura 39 - Máquina Empilhadeira

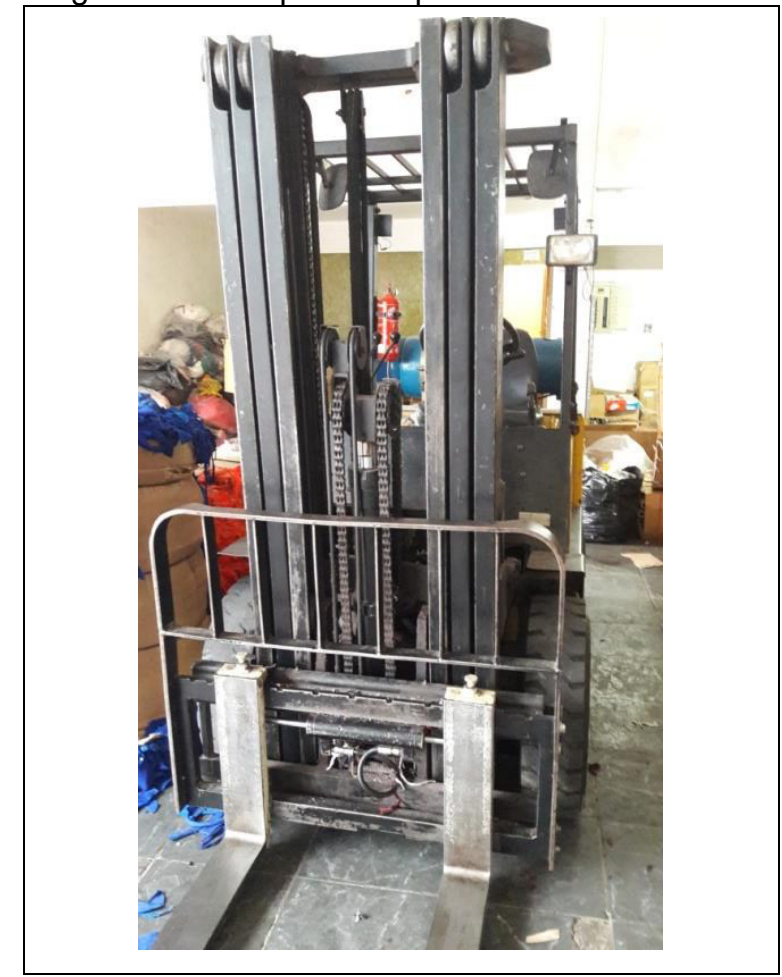

Fonte: foto da autora.

Os fardos ficam reservados abaixo da escada e próximos do local de retirada. Toda a reciclagem é dividida em três ambientes, onde o primeiro ambiente é para o trabalho com resíduo têxtil, o segundo para trabalhar-se com papelões e plásticos em geral, e o terceiro ambiente é a área de administração e serviços gerais.

$\mathrm{Na}$ Figura 40, pode-se visualizar os fardos de tricô todos empilhados no galpão da reciclagem, prontos para serem comercializados. Cabe ressaltar que o armazenamento dos fardos prontos é sempre em áreas cobertas para serem protegidos da chuva, além de possuírem uma base de papelão utilizada no fundo e na tampa do fardo, antes do mesmo ser amarrado e finalizado, proporcionando uma facilidade no manuseio e evitando possíveis contaminações mais grosseiras no transporte. 
Figura 40 - Fardos empilhados no setor de reciclagem.

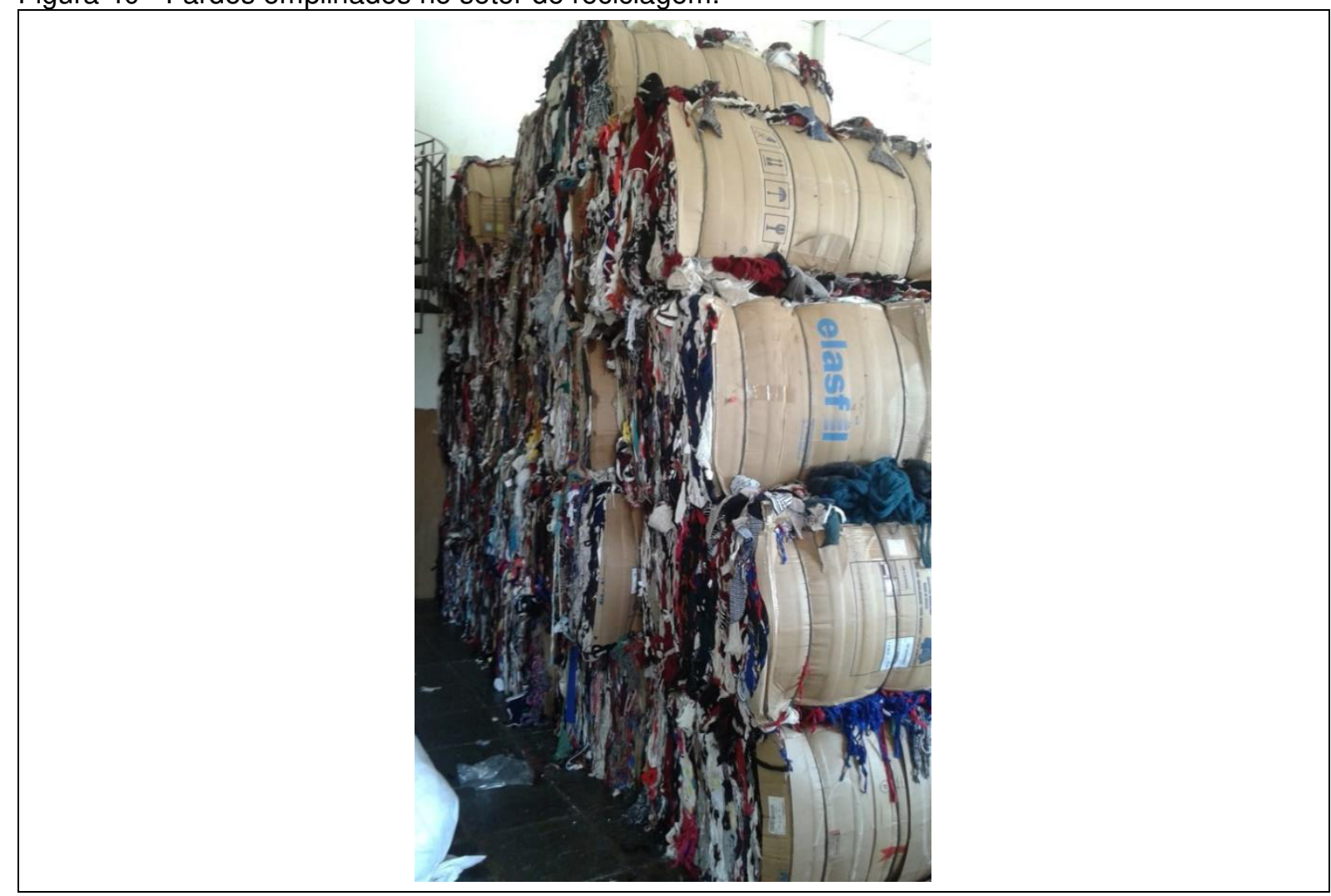

Fonte: foto da autora.

Sobre a evolução da maquinaria nas malharias o respondente explica que com a chegada da maquinaria importada na região no decorrer dos anos, o padrão de produção começou a tomar uma nova forma. Isto se deve ao avanço tecnológico, que faz com que a peça seja produzida consumindo de maneira mais apropriada a matériaprima e fabricando uma roupa com menos etapas de corte.

Com relação à retirada de resíduos nas malharias, o entrevistado relata que é muito difícil encontrar uma malharia que deixe o resíduo bem limpo e selecionado, por mais que esteja separado em caixa de papelão ou pacote plástico, vem sempre um papel junto, ou plástico. Deste modo, o trabalho de uma rigorosa seleção fica por conta da reciclagem mesmo, com os operadores que trabalham na mesa de seleção. Evidencia ainda, que quando o resíduo vem muito poluído automaticamente se paga um valor menor.

Relata ainda o proprietário da reciclagem que com relação ao resíduo muitas vezes a malharia não se dá conta do quanto que acumulou em um ano ou mais, explica que tem empresa que guarda mesmo, porque acha que vai servir para algo, ou que pretende usar de outro modo, mas depois percebe que isso não acontece, e por fim os resíduos vão crescendo e ocupando muito espaço. Porém "tem malharias que 
pedem pra coletar três vezes na semana porque tem pouco espaço" (informação verbal) ${ }^{12}$.

Quando a caixa de resíduo chega à empresa de reciclagem é realizada uma separação, neste processo tudo é manual. Os resíduos são despejados na mesa de ferro em forma de grade, onde pode-se enxergar o que é papel, plástico, e tecido, feito esta seleção que é muito trabalhosa, o material é encaminhado para ser prensado e então formarem-se os fardos.

Nesta mesa (Figura 41), são separados todos os tipos de materiais inclusive aqueles que não terão serventia. A grade funciona como uma peneira para que pequenos itens como tampinhas, botões e outros componentes sejam excluídos. Desta maneira, o trabalho é controlado pelos operários selecionadores, que fazem movimentos rápidos e repetidos no processo de separação, considerado como uma das etapas mais difíceis e trabalhosas da reciclagem.

Figura 41 - Mesa de ferro com grades setor de reciclagem.

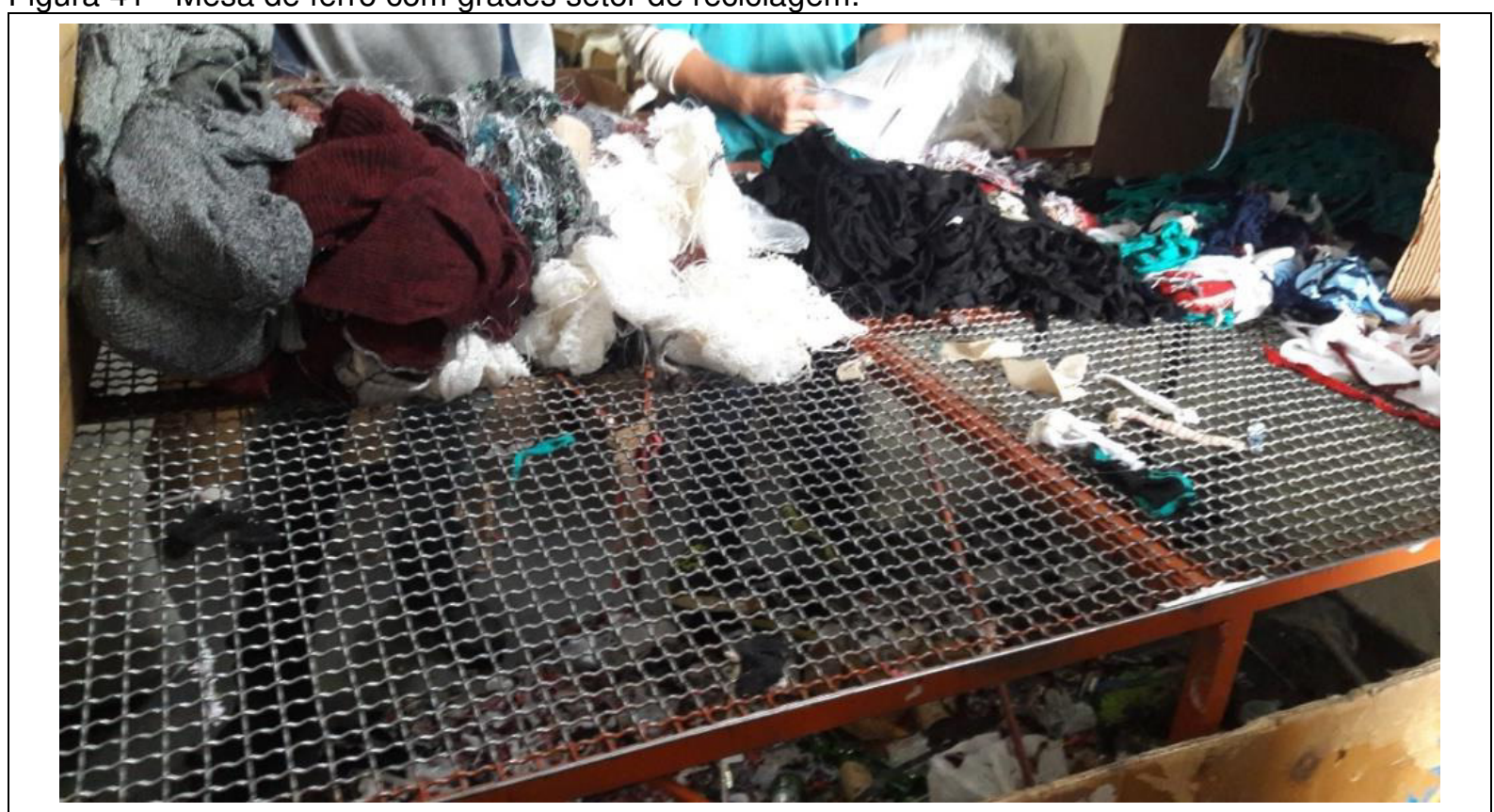

Fonte: foto da autora.

Em alguns casos ainda são encontrados outros tipos de resíduos juntos como: papelão de diversos tipos, agulhas de teares, copos plásticos e embalagens plásticas, cones de plástico e de papelão. Quando isso ocorre, automaticamente a reciclagem sofre uma perda devido ao tempo gasto para a limpeza, então este valor é abatido.

12 Informações fornecidas pelo(a) respondente da "reciclagem" em entrevista realizada pela autora no ano de 2017. 
Os tecidos, depois de separados, são jogados dentro de uma prensa, como mostra a Figura 42, que é responsável pela formação dos fardos que costumam pesar entre $180 \mathrm{~kg}$ e $200 \mathrm{~kg}$. O fardo recebe uma pressão muito grande compondo um bloco de tecidos bem rígido.

As prensadoras são de suma importância neste setor. Os tecidos são colocados no local manualmente preenchendo o recipiente, e a prensa é acionada automaticamente (Figura 43) por um funcionário em seguida pressiona-se o material e libera-se o fardo pronto.

Figura 42 - Prensa automática onde formam se os fardos no setor de reciclagem.

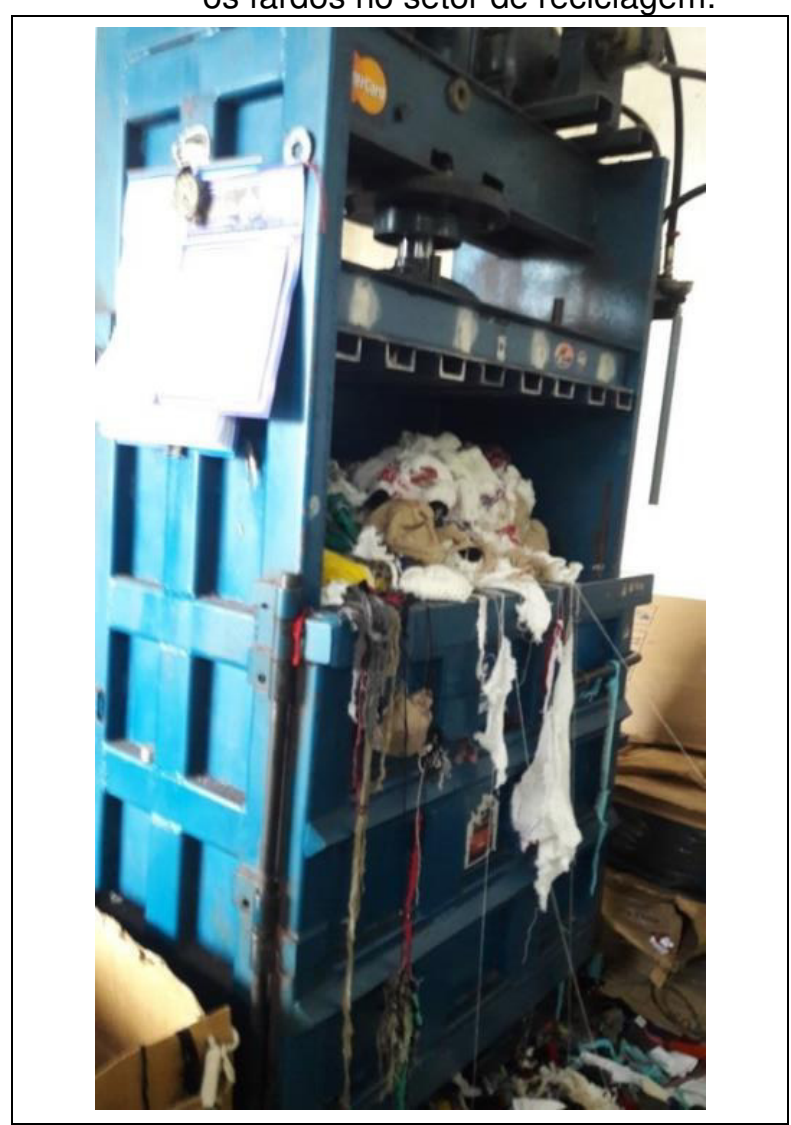

Fonte: foto da autora.
Figura 43 - Prensa sendo acionada.

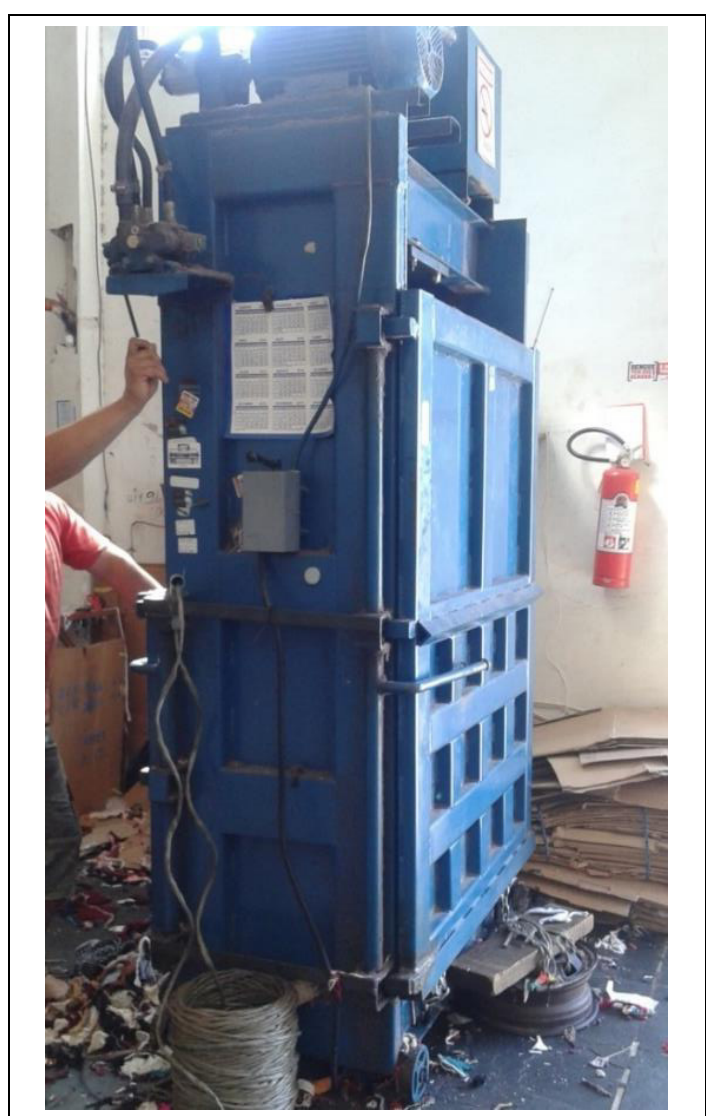

Fonte: foto da autora.

No decorrer do depoimento narra como o material produzido por eles é chamado "o que adquire conosco denominam têxtil acrílico [...] tanto de inverno quanto de verão" (informação verbal) ${ }^{13}$.

Deste modo, os fardos que saem da reciclagem são nomeados de têxtil acrílico, devido a principal matéria-prima ser feita de fibra acrílica utilizada para a fabricação

\footnotetext{
${ }^{13}$ Informações fornecidas pelo(a) respondente da "reciclagem" em entrevista realizada pela autora no ano de 2017.
} 
de roupas de tricô, mesmo que existam porcentagens de misturas ainda assim a base maior é de fibra acrílica.

Em seguida, complementa com a descrição e características do produto que fazem na reciclagem. Um destes é o fardo de uma cor só onde se junta todos os tons de azuis por exemplo e então forma-se um fardo único. Isso porque há clientes que querem uma cor só já separada porque estes resíduos serão refiados.

A Figura 44 mostra um fardo de aproximadamente $180 \mathrm{~kg}$ de malha tricô prensado, onde pode-se visualizar que foi formado por várias tonalidades de azuis. Os resíduos que formam o fardo contêm diferentes nuances de azuis, diferentes tamanhos, e texturas. O fardo é destinado a empresa que vai prepará-lo para um reaproveitamento, possivelmente sendo refiado para ser transformado em fio reciclado onde serão feitos tapetes e cobertores.

Figura 44 - Fardo de uma cor só 180 kg setor de reciclagem.

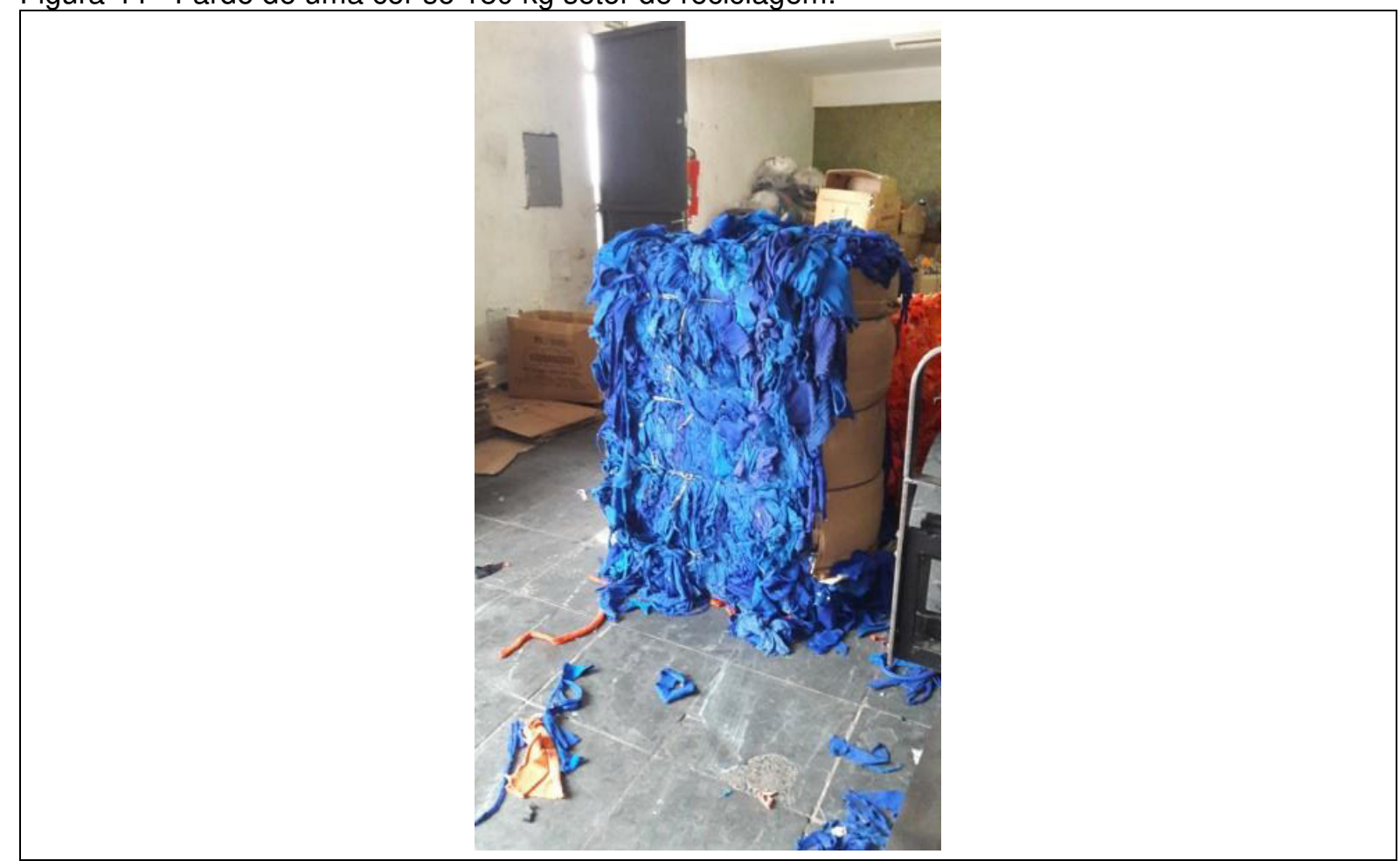

Fonte: foto da autora.

$\mathrm{Na}$ Figura 45, pode-se notar que os retalhos que são recebidos por cor, são devidamente armazenados, assim formando um montante de tons de vermelho, azul, preto e branco, para em seguida serem levados para a prensa, e formarem fardos chamado de cor única como a Figura 46. 
Figura 45 - Caixas contendo têxtil chamado de cor única

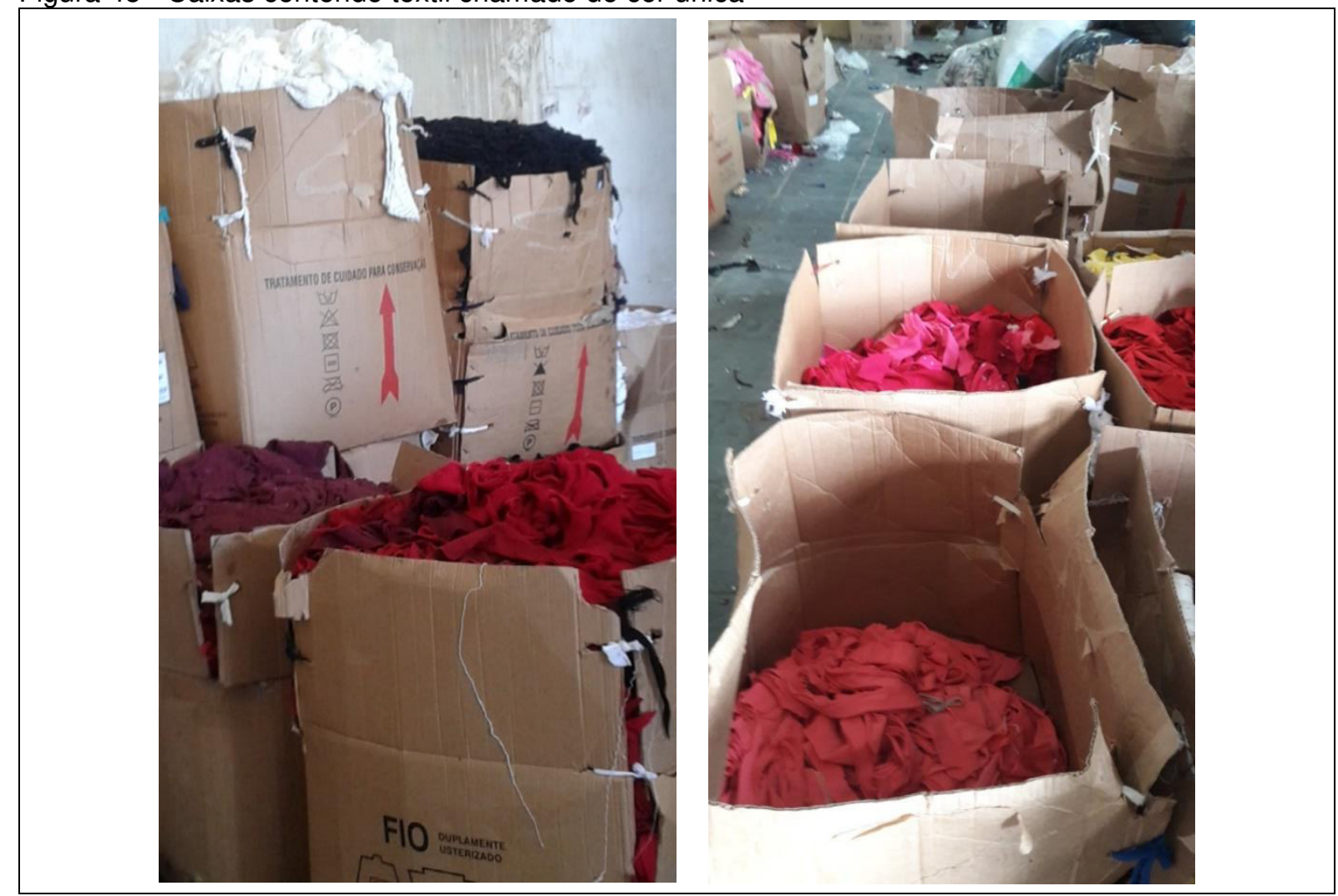

Fonte: foto da autora.

Figura 46 - Fardos de cor única prontos para serem transportados.

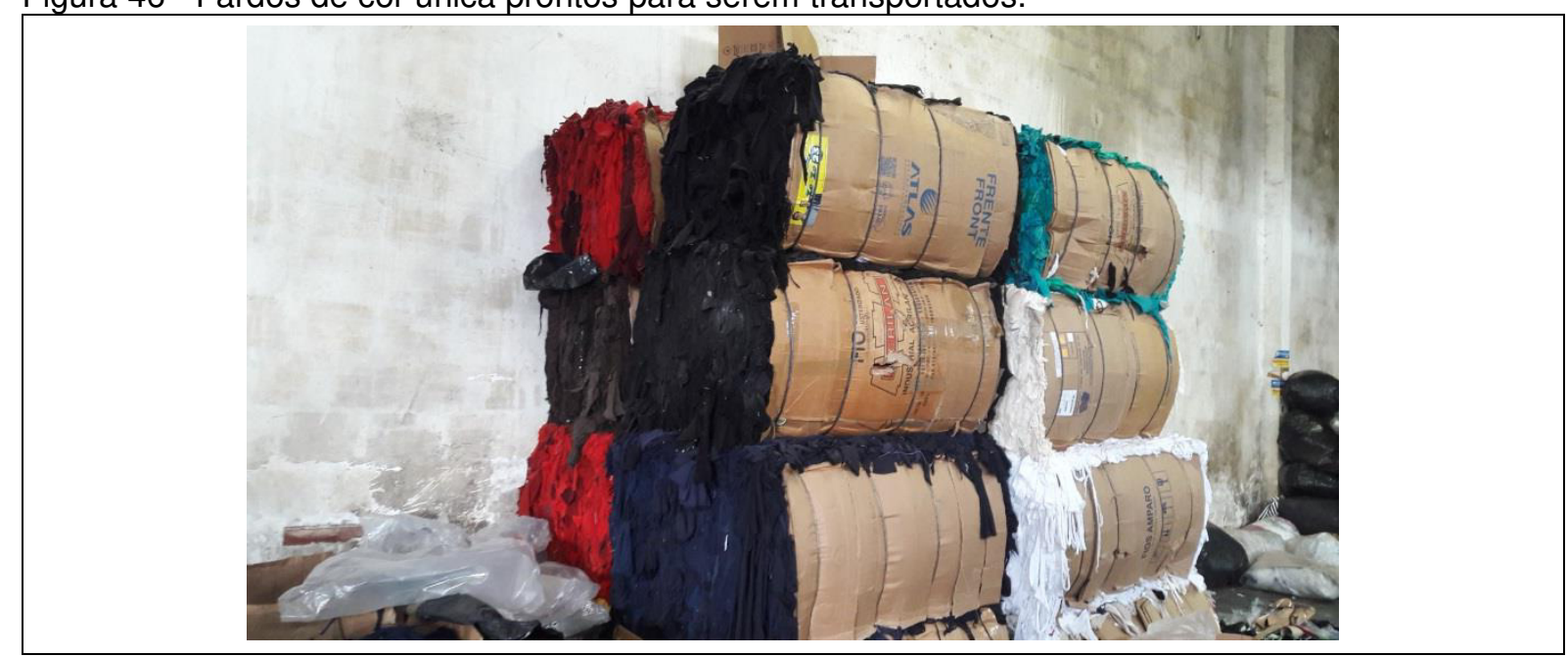

Fonte: foto da autora.

Outro fardo de tricô que é constituído é o chamado mil cores (Figura 47) conforme o respondente relatou: "onde se prensa tudo junto [...] são todas as cores juntas [...] listrados [...] fios de separação, restos cortados formando uma mistura" (informação verbal) $)^{14}$.

${ }^{14}$ Informações fornecidas pelo(a) respondente da "reciclagem" em entrevista realizada pela autora no ano de 2017. 
$\mathrm{Na}$ Figura 48, pode-se notar que se misturam fragmentos de retalhos de inúmeras cores e tipos se tornando um único produto chamado de mil cores, em que encontramse reunidos tecidos pequenos do corte, tecidos de acabamento, tiras, golas, tecidos grandes descartados e emaranhados de separação.

Figura 47 - Fardos de mil cores prontos

Figura 48 - Fardo de $180 \mathrm{~kg}$ chamado mil cores. para serem transportados.

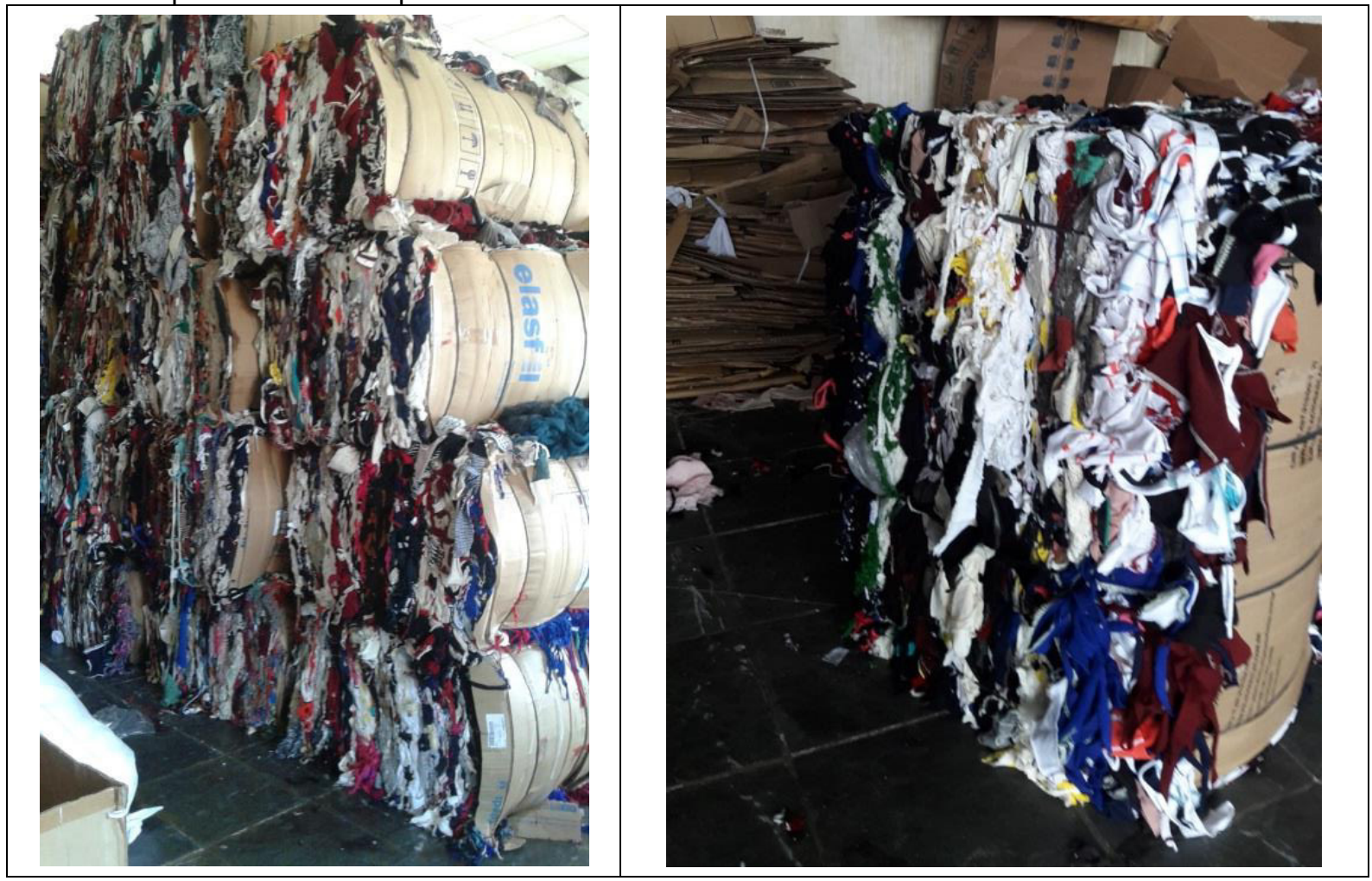

Fonte: foto da autora.

Fonte: foto da autora.

Com relação ao destino dado aos fardos denominados mil cores, é informado que são encaminhados para serem reaproveitados pela indústria automotiva.

Deste modo pode-se notar, que uma das finalidades dada ao resíduo sólido têxtil tricô é encontrada no mercado de automóveis, como um acessório (manta acústica) que tem a função de diminuir os ruídos.

Sobre os outros materiais que chegam na reciclagem relata que recebem cones de papelão e plástico e que estes vem envolvidos com o produto têxtil de malharia.

Deste modo, pode-se verificar na Figura 49, a caixa contendo esta mistura, para depois ser devidamente separada, pois é possível visualizar cones com fios e garrafas pet, que se encontram perdidos neste meio. 
Figura 49 - Caixa de resíduos contendo cones de fios de papelão misturados com cones de plásticos, garrafas pet e fios.

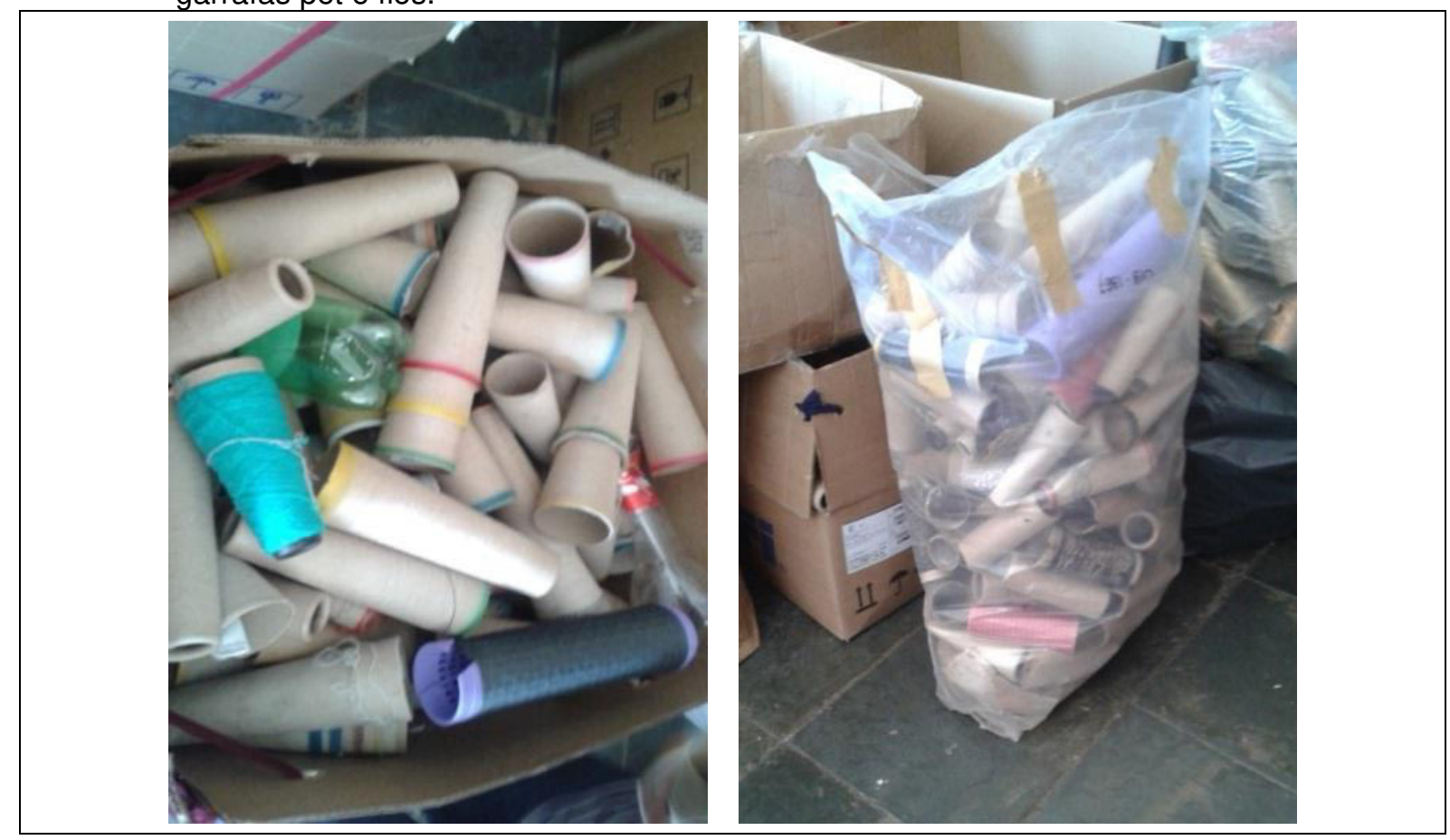

Fonte: foto da autora.

O cone por sua vez será enviado para remanufaturar e o fio será inserido no lote de resíduo têxtil mil cores. Desta forma, são devidamente preparados os cones (resíduos) cada um com sua classificação (papelão ou plástico) colocados em caixas de papelão agrupados e amarrados.

Quanto aos cones de fios, existe ainda uma classificação para cada tipo e tamanho. São separados e especificados conforme a classificação como mostra a Figura 50 e cada um tem um destino diferenciado como, por exemplo: alguns são enviados para remanufatura da borda e base do próprio fabricante de cone, e outros são reaproveitados em outros segmentos como suporte. 
Figura 50 - Caixa contendo cones de papelão ordenados para a remanufatura.

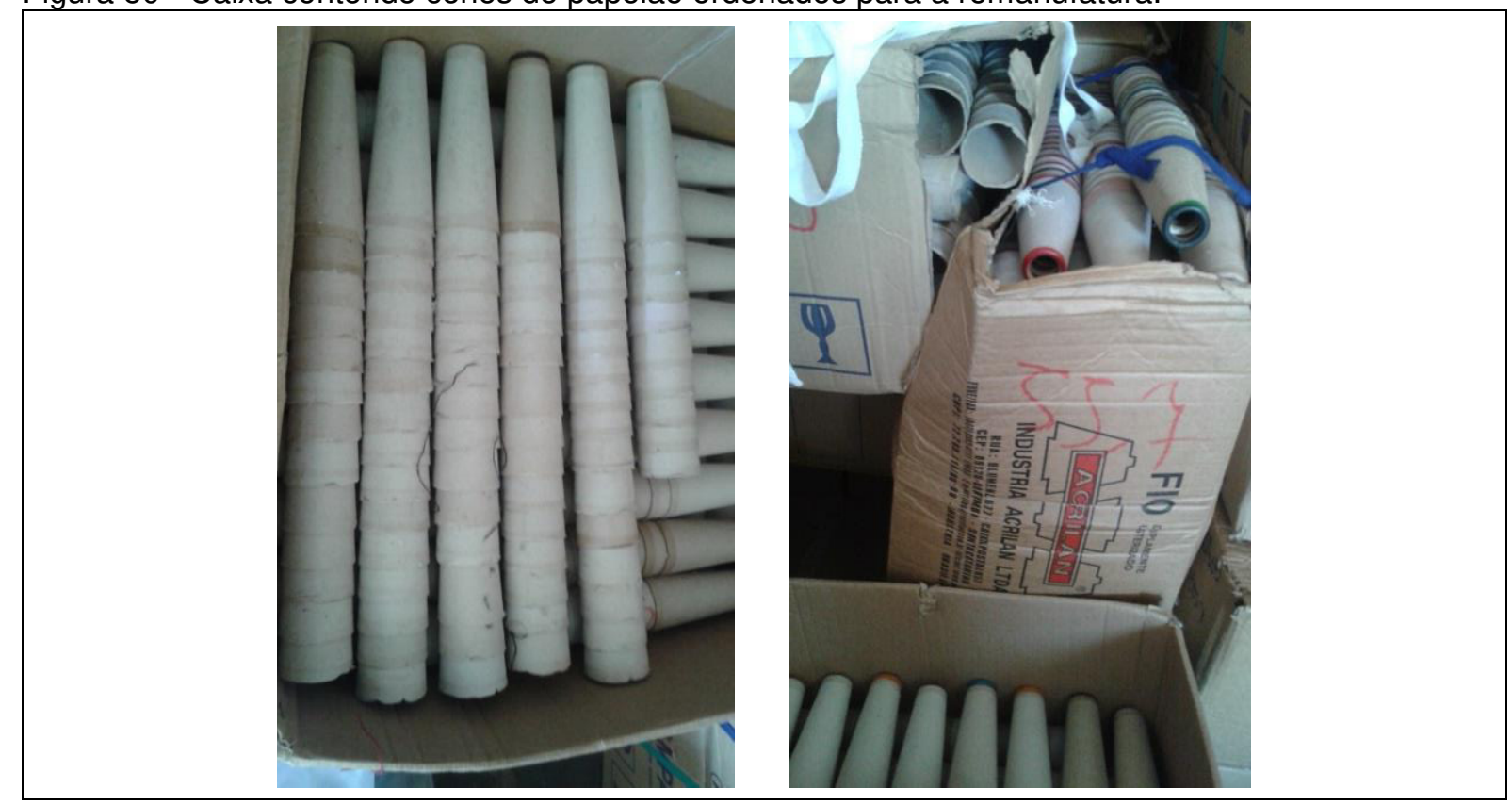

Fonte: foto da autora.

Outro produto que está embutido neste segmento e é comum, pois, faz parte das embalagens, são as caixas de papelão. Estas na reciclagem são tratadas com muito valor, pois além de servirem para o manuseio dos resíduos, são separadas como mostra a imagem abaixo para serem prensadas (Figura 51), quando já estão no fim de sua vida útil.

Figura 51 - Papelão separado para ser prensado.

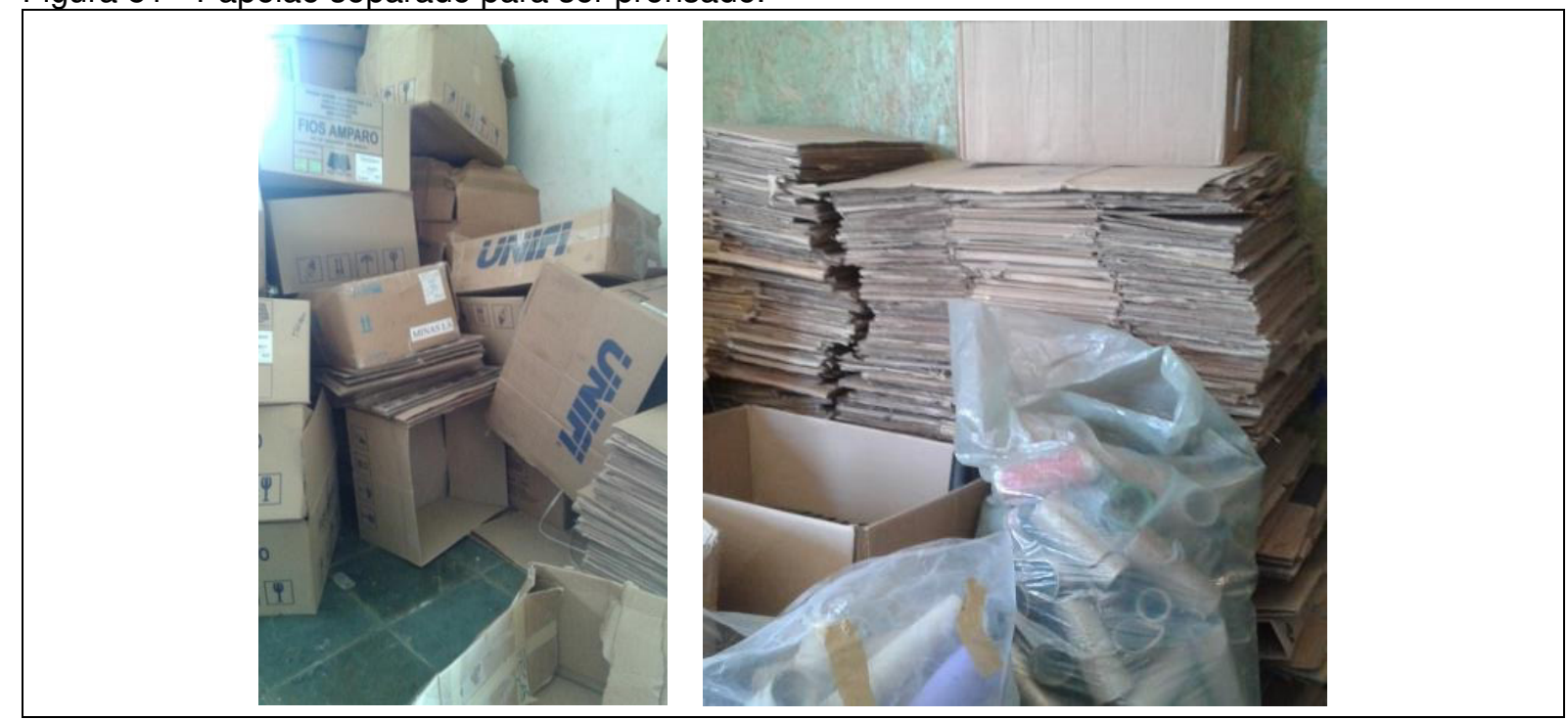

Fonte: foto da autora.

Neste cenário são formados os fardos como mostra a Figura 52, contendo papel e papelão de diversos tamanhos e espessuras. 
Figura 52 - Fardo de papelão prensado.

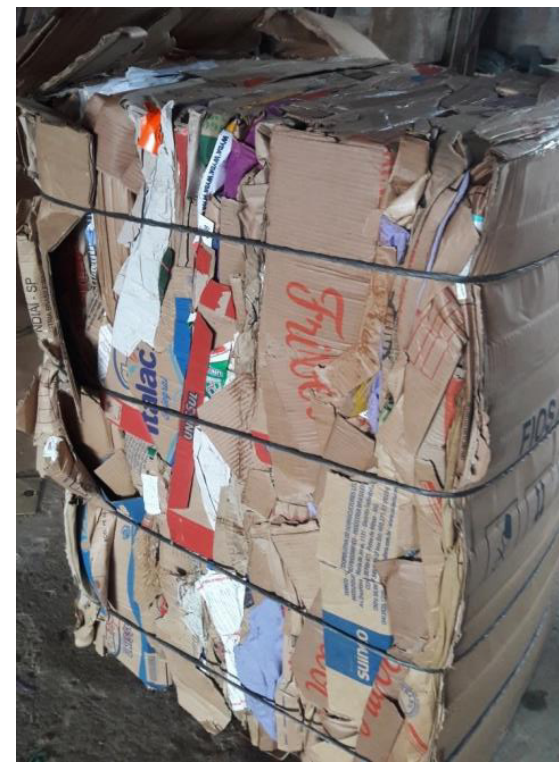

Fonte: foto da autora.

Os fardos pesam $180 \mathrm{~kg}$ e são constituídos em prensas, e alocados no segundo ambiente da reciclagem devido a quantidade de sua produção ser menor.

No relato, o respondente, resumidamente, fez um apanhado geral da quantidade de resíduos produzidos em meses de alta produtividade na região, oferecendo uma ideia das proporções de cada uma das principais classes de resíduos recebidos: "É de janeiro a junho que as malharias trabalham com mais intensidade $100[\ldots] 150[\ldots]$ a 200 toneladas de resíduos, sendo que aproximadamente $70 \%$ a $75 \%$ é de têxtil o resto é de cone, papelão e plástico" (informação verbal) ${ }^{15}$.

Neste contexto, percebe-se que mais da metade dos resíduos trabalhados são têxteis, advindos das fábricas que compõem o polo. O restante é composto por plástico e papelão, correspondendo aos suportes dos fios e as embalagens dos mesmos. Notase, também, que a quantidade é bastante elevada, complementa com relação ao aproveitamento: "O aproveitamento é excelente a gente até pensa se não tivesse estas empresas que compram os resíduos o que faríamos com eles" (informação verbal) ${ }^{16}$ o respondente comenta, que lembra como estes eram tratados antigamente, queimados em céu aberto.

O respondente completa: "acredito fazer um bem para cidade" (informação verbal)17 que assim como a sua empresa existem outras localidades que também trabalham

\footnotetext{
15 Informações fornecidas pelo(a) respondente da "reciclagem" em entrevista realizada pela autora no ano de 2017.

16 Informações fornecidas pelo(a) respondente da "reciclagem" em entrevista realizada pela autora no ano de 2017.

17 Informações fornecidas pelo(a) respondente da "reciclagem" em entrevista realizada pela autora no ano de 2017.
} 
com a reciclagem de resíduo de malharia, o "têxtil acrílico", o que é bem significativo, pois, com desenvolvimento do setor se faz necessário também aumentar o tratamento dos seus rejeitos.

Acredita que, com o desenvolvimento e aprimoramento das tecnologias, houve sim uma melhora significativa no processo produtivo na concepção da malha, pois esta passou a ser elaborada de forma a consumir de modo estratégico o material investido, e também neste mesmo pensamento passou a gerar menos retalho quando houve a automatização dos processos eliminando etapas que provocariam os resíduos. Porém, quando analisa-se de outro ângulo, percebe-se que a cidade se desenvolveu consideravelmente e este crescimento trouxe a abertura de muitas outras malharias que trabalham diariamente e investem em suas empresas, neste contexto, acredita então que a produção de resíduos atualmente não cresceu muito e se encontra balanceada.

Deste modo, relata no fragmento seguinte para onde as reciclagens enviam estes fardos de têxtil acrílico: "vende para São Paulo, São Carlos, Santa Barbara d'oeste Nova Odessa, Camanducaia. Estes locais são outras indústrias que compram este tipo de material, e as transformam em outros produtos, trabalhando o resíduo de forma a utilizar ainda estes para que possam ser reinseridos mesmo que de forma remanufaturada e diversa no mercado".(informação verbal) ${ }^{18}$.

Por fim, no terceiro ambiente, em que se encontra a parte de administração da reciclagem, ocorre também o desenvolvimento do aproveitamento de alguns tecidos que são trabalhados minuciosamente construindo-se peças.

No processo de separação são encontrados tecidos de malha, em tamanhos maiores, estes são selecionados e enviados para a costureira da reciclagem que com sua experiência e habilidade consegue transformar pedaços de tecidos diversificados em peças como pode-se verificar nas Figura 53 e 54.

${ }^{18}$ Informações fornecidas pelo(a) respondente da "reciclagem" em entrevista realizada pela autora no ano de 2017. 
Figura 53 - Peça elaborada no setor de reciclagem

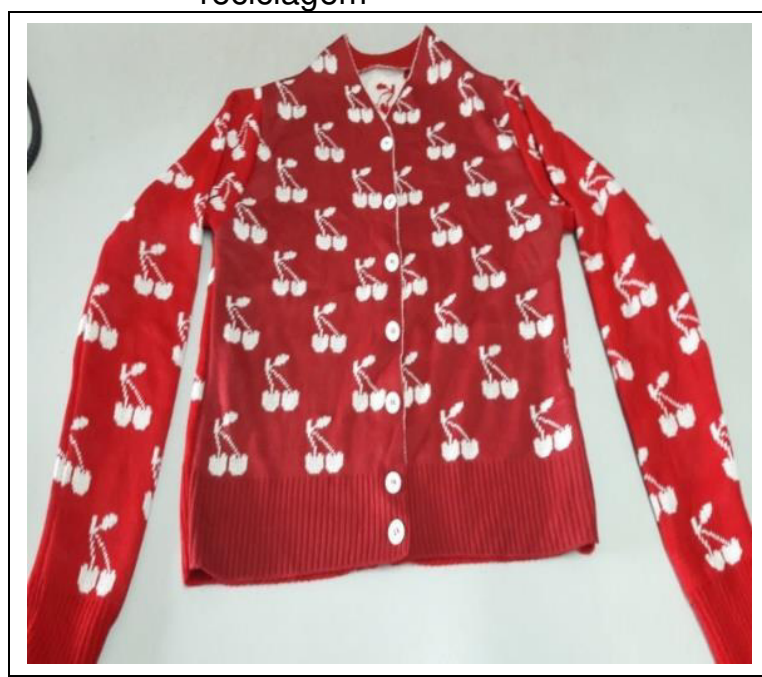

Fonte: foto da autora.
Figura 54 - Cardigan com abotoamento duplo

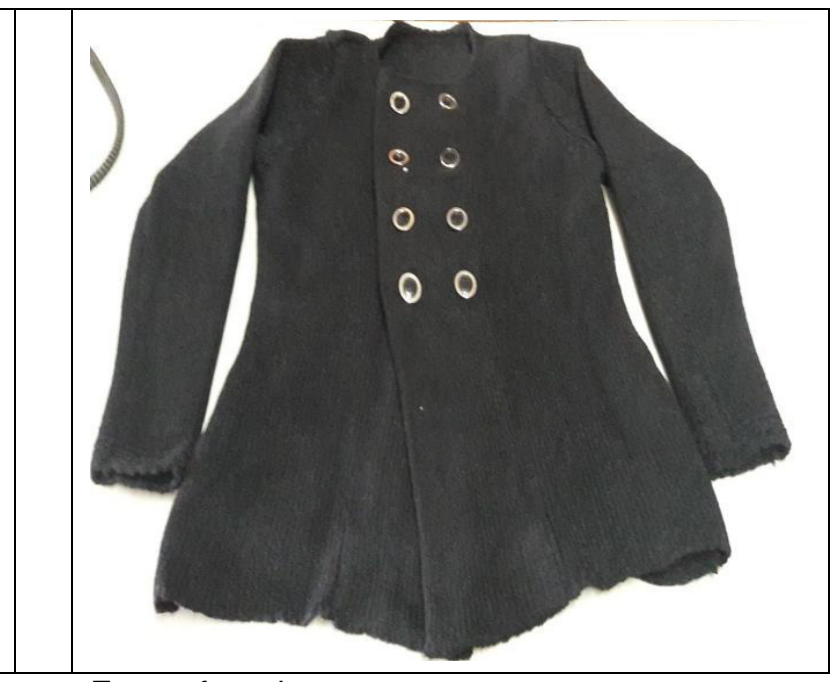

Fonte: foto da autora.

Desta forma é possível elaborar peças únicas, consumindo da melhor maneira o material encontrado. Neste contexto, pode-se notar que na própria reciclagem, além de todos os processos de grande importância quanto aos resíduos sólidos, encontrase a remanufatura constituindo, a partir disto, novas peças do que seria descartado como resíduo, ampliando desta forma o ciclo de vida daquele material. Percebe-se assim, em visita, que tudo é tratado com muito empenho e observa-se a satisfação dos proprietários na realização do trabalho e na demonstração do mesmo. 